\title{
Geophysical Database of the East Coast of the United States: Southern Atlantic Margin - Stratigraphy and Velocity in Map Grids
}

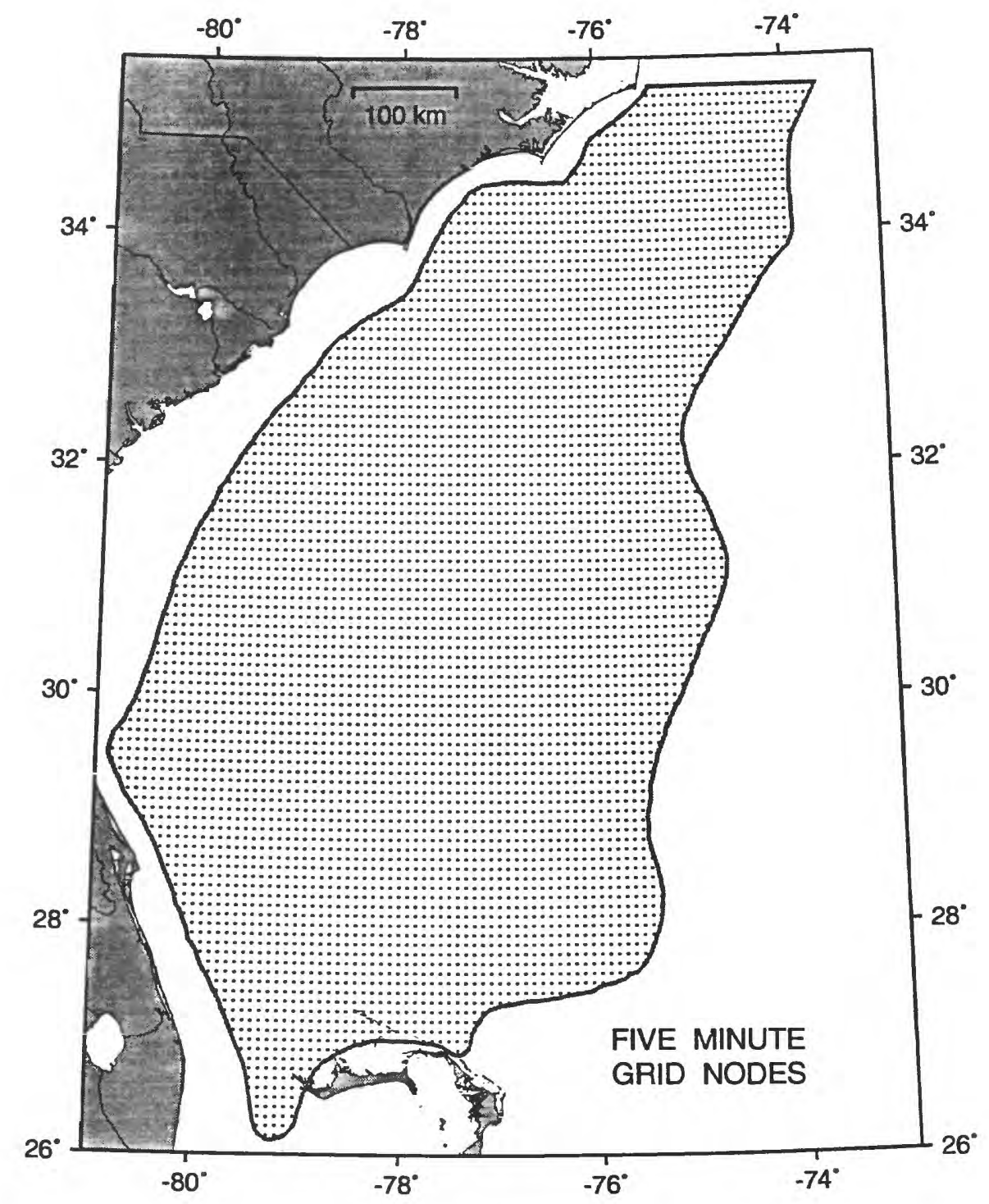

D.R. Hutchinson, C.W. Poag, A. Johnson, P. Popenoe and C. Wright U.S. Geological Survey Woods Hole, MA 02543

U.S. Geological Survey Open File Report 96-55 


\title{
Geophysical Database of the East Coast of the United States: Southern Atlantic Margin - Stratigraphy and Velocity in Map Grids
}

\author{
by \\ D.R. Hutchinson, C.W. Poag, A. Johnson, P. Popenoe and C. Wright \\ U.S. Geological Survey \\ Woods Hole, MA 02543
}

U.S. Geological Survey

Open File Report 96-55

This report is preliminary and has not been reviewed for conformity with U.S. Geological Survey editorial standards and nomenclature. Use of trade names is for the purposes of identification only and does not contitute endorsement by the U.S. Geological Survey. 


\section{TABLE OF CONTENTS}

Introduction

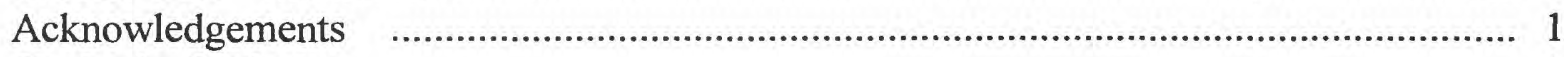

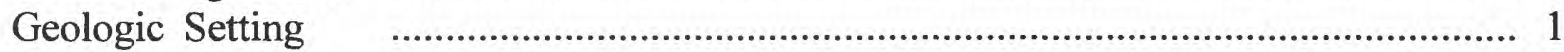

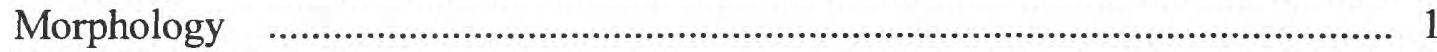

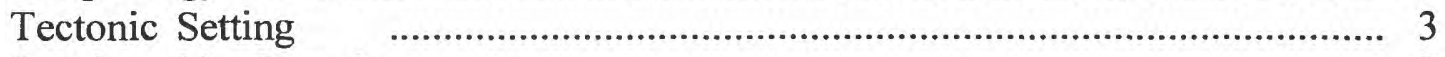

Stratigraphic Overview ……................................................................ 3

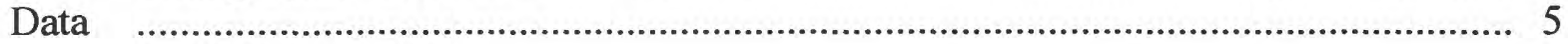

Multichannel Data _............................................................................. 5

Digital Stratigraphic Data _................................................................. 7

Digital Velocity Data _....................................................................... 7

Lithology Data ……….......................................................................... 7

Surface Grain Size Data ....................................................................... 9

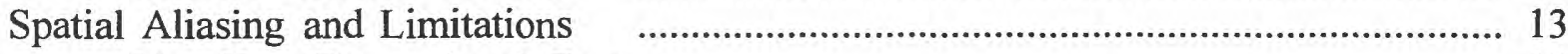

Non-Two-Dimensional Features ………................................................ 13

Two-Dimensional Discontinuities …..................................................... 13

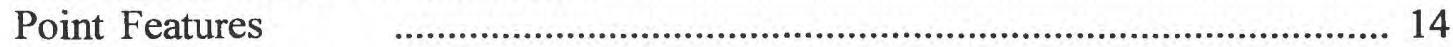

Construction of Grids

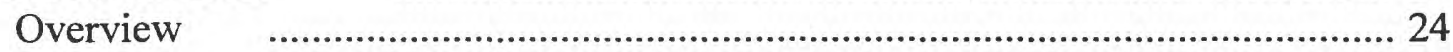

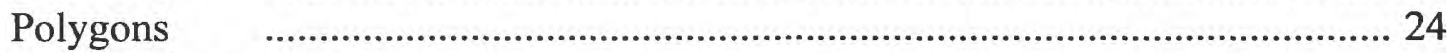

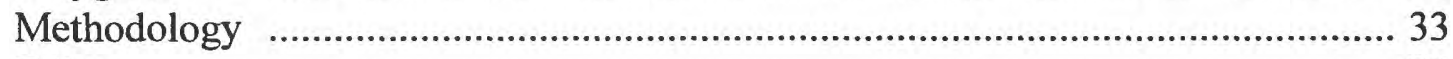

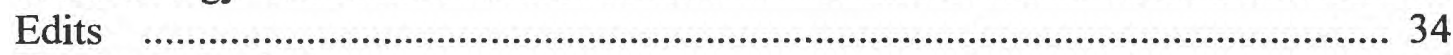

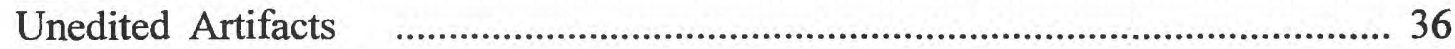

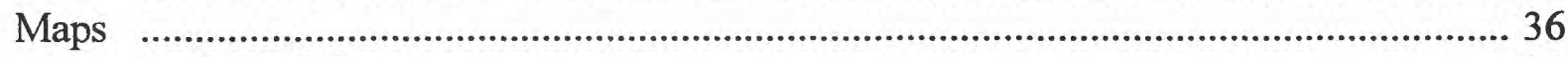

Isochron Maps ………............................................................................ 36

Interval Velocity Maps ……….............................................................. 37

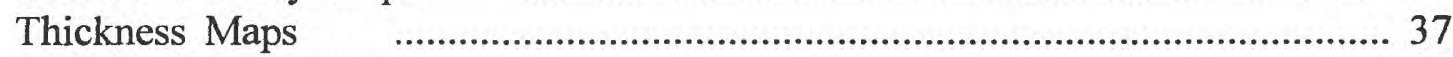

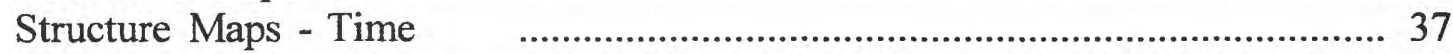

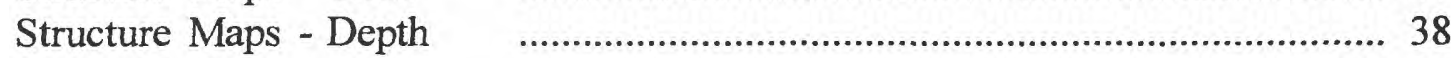

Lithology Maps …………........................................................................ 38

Construction of Geoacoustic Database …....................................................... 39

Geoacoustic Parameters …….................................................................... 39

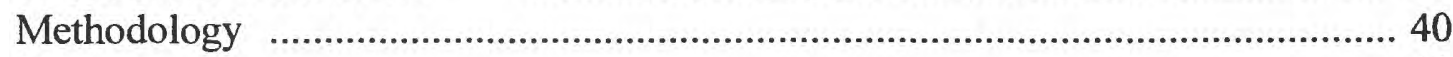

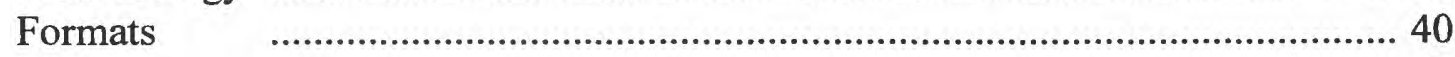

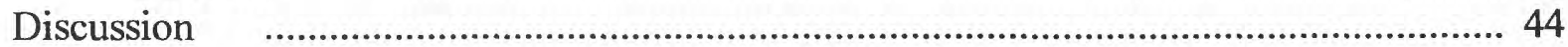

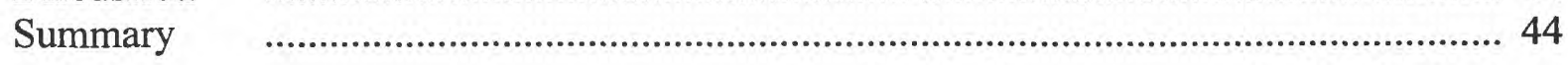

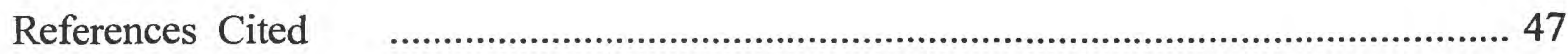

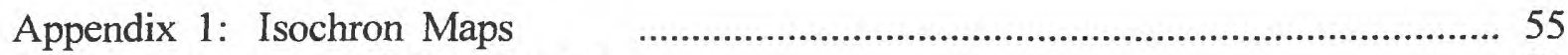

Appendix 2: Interval Velocity Maps ……...................................................... 73

Appendix 3: Thickness Maps ….................................................................... 91

Appendix 4: Structure Maps in Time ………................................................... 109

Appendix 5: Structure Maps in Depth …………................................................ 128

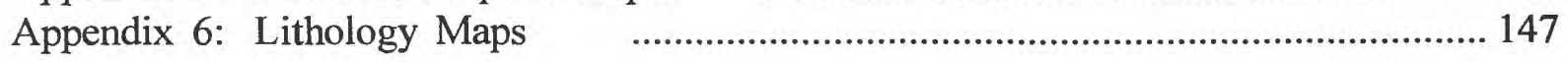




\section{LIST OF TABLES}

Table 1: Descriptive Information about Multichannel Profiles .............................. 9

Table 2: U.S. Atlantic Margin Seismic Stratigraphy $\quad$............................................ 11

Table 3: Locations of Well and other Samples ……............................................ 16

Table 4: Independent Velocity Information …............................................... 17

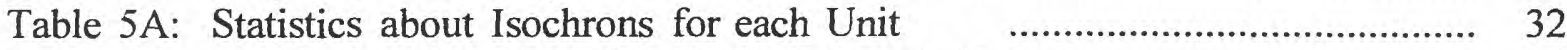

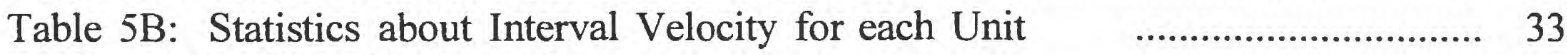

Table 6: General Lithologic Types ……....................................................... 39

Table 7: Geoacoustic Parameters and Formulas ...................................................... 42

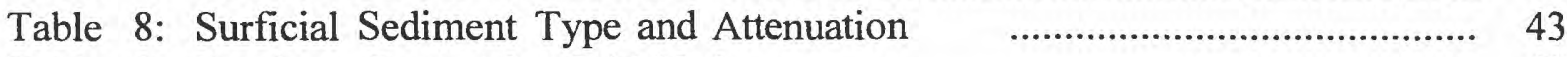

Table 9: Database Format by Grid Node $\quad$........................................................ 43

Table 10: Database Format by Horizon Number ........................................................ 43

\section{LIST OF FIGURES}

Figure 1: Physiography of the U.S. Continental Margin south of Cape Hatteras 2

Figure 2: Simplified Tectonic Map, Cape Hatteras to the Bahamas 4

Figure 3: Locations of Profiles used in Constructing Database 6

Figure 4: Locations of Profiles and Calibrating Sample Information 8

Figure 5: Hypothetical Stratigraphy with Terminology and Labelling Conventions 10

Figure 6: Representative Multichannel Profile Line 32 across the Carolina Trough 12

Figure 7: Representative Multichannel Profile TD-4 across the Blake Escarpment 14

Figure 8: Map showing Locations of Velocity Scan Control Points 19

Figure 9: Map showing Locations of Independent Velocity Information 21

Figure 10: Map showing Locations of and Contours of Grain Size Information 23

Figure 11: Zero-tension Gridding of Bathymetry from Multichannel Profiles 25

Figure 12: Maximum-tension Gridding of Bathymetry from Multichannel Profiles 27

Figure 13: Map showing the Distribution of Salt Diapirs along the Carolina Trough 29

Figure 14: Map showing Locations of Grid Nodes within the Study Area 31

Figure 15: Flow chart showing Construction of Grids from Digital Profile Data 35

Figure 16: Map of Surface Compressional-wave Attenuation 41 


\section{INTRODUCTION}

In 1990, the Naval Oceanographic Office and the U.S. Geological Survey agreed to develop a digital data base of stratigraphy and acoustic properties of sediments along the U.S. East Coast of the United States. The objective of this work was to utilize more than 25,000 $\mathrm{km}$ of publically available multichannel seismic-reflection profiles (Sheridan et al., 1988) in order to assign acoustic properties to the continental margin postrift sediments in an internally consistent, geologically meaningful, regionally extensive, digital form. The acoustic properties of interest include thickness, depth, compressional- and shear-wave velocity, compressionaland shear-wave attenuation, density, and lithology. This data base subdivides the 0 - to $14-\mathrm{km}$ thick Jurassic and younger postrift deposits into 18 mappable horizons. The spatial scale of gridding is 5 ' latitude by 5 ' longitude, or about $9 \times 8 \mathrm{~km}$.

This report describes the second part of developing the data base for the continental margin between Florida and Cape Hatteras: spatial gridding of the digital stratigraphic and velocity data, derivative calculations of density, shear-wave velocity, and attenuation, and construction of the final data base. The first report (Hutchinson et al., 1995) describes how the stratigraphy and velocity were digitized from the original profiles. Complementary reports that describe the data base for the area between Cape Hatteras and Georges Bank are given in Klitgord and Schneider (1994) and Klitgord et al. (1994).

\section{ACKNOWLEDGEMENTS}

Funding for this project was provided by the U.S. Naval Oceanographic Office. We gratefully thank Dr. Rudi Markl, project manager from the Naval Oceanographic Office during most of this work, for his technical advice, discussions, and support. We also thank Peggy Schexnayder, Ashok Kalra, and Gus Michel of the U.S. Naval Oceanographic Office, for their encouragement and we gratefully acknowledge Peggy Schexnayder's perseverence in obtaining the two surface grain size points from the abyssal plain. Jack Hathaway provided quidance on accessing his database of grain-size information. The GMT data management system developed by Wessel and Smith (1991) were used in this project to construct the digital grids and graphic output. Discussions with and reviews by Kim Klitgord and Bill Dillon have resulted in significant improvements to this work. We thank D. Coleman, L. North, C. Schneider, D. Unger, and E. Wright for technical assistance throughout the project.

\section{GEOLOGIC SETTING}

\section{Morphology}

The continental margin between Cape Hatteras and Florida juxtaposes the narrowest (Cape Hatteras) and widest (Blake Plateau) segments of the U.S. Atlantic margin (Figure 1). The Blake Plateau is a large submerged platform, measuring about $350 \times 800 \mathrm{~km}$ in about 800 $\mathrm{m}$ water depth, which interrupts the Florida-Georgia continental slope. The seaward edge of the plateau is the Blake Escarpment, the steepest morphologic feature of the U.S. East Coast, located between the Bahamas and the Blake Spur. The Hatteras abyssal plain forms the deep ocean floor adjacent to the continental margin. Two additional features, the Blake Outer Ridge (Markl et al., 1970; Markl and Bryan, 1983; Mountain and Tucholke, 1985) and the Charleston Bump (Pinet et al., 1981) are obvious morphologic features of the margin. 


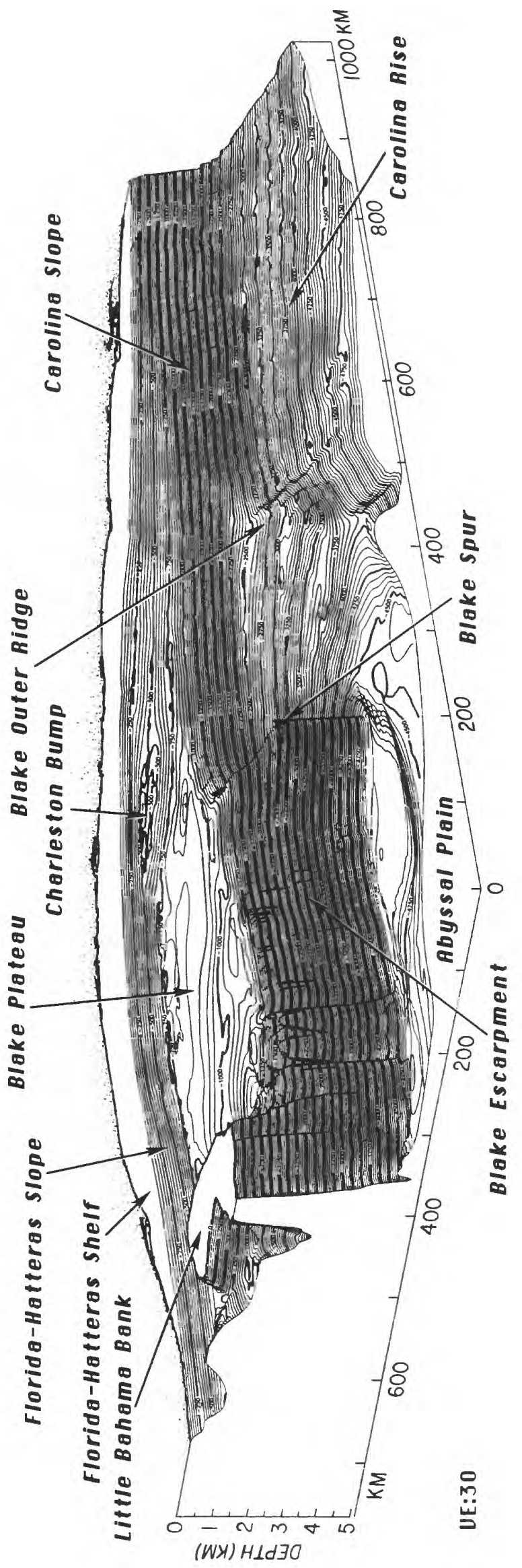




\section{Tectonic Setting}

The tectonic development of the two large sedimentary basins (Figure 2) off the southeast U.S., the Carolina trough and Blake Plateau basin, has been described by numerous workers (e.g., summary papers of Dillon et al., 1985; Klitgord et al., 1988; Dillon and Popenoe, 1988; Poag, 1991; Rankin et al., 1991; Hatcher et al., 1994). The Carolina trough began evolving about $175 \mathrm{Ma}$ when sea-floor spreading began; the Blake Plateau basin continued rifting for an additional $4 \mathrm{~m} . \mathrm{y}$. until sea-floor spreading was initiated at about 171 Ma (Dillon and Popenoe, 1988).

Basement rocks beneath the sediments of the Carolina trough are interpreted to be dominantly basaltic volcanics extruded and intruded into Appalachian basement rocks during rifting (Holbrook and Keleman, 1993). Basement rocks beneath the Blake Plateau basin are poorly known from either samples or velocity data, but are probably similar to the mixed composition inferred beneath the Carolina trough (Dillon and Popenoe, 1988). Several oceanic fracture zones extend towards the continental margin from oceanic crust; the largest of these, the Blake Spur fracture zone, separates the Carolina trough from the Blake Plateau basin (Klitgord and Behrendt, 1979).

\section{Stratigraphic Overview}

The Mesozoic and Cenozoic stratigraphy of the Carolina trough and Blake Plateau basin is based on interpretations of multichannel seismic-reflection profiles calibrated by limited samples (e.g., Dillon and Popenoe, 1988), seismic correlations to the north and south of the study area (Poag, 1991), and maps of the sea-floor age and geology of the continental margin (Paull et al., 1980; Popenoe, 1993). No dated samples older than Early Cretaceous have been recovered from this part of the continental margin in either shallow or deep water (Sheridan and Enos, 1979; Dillon and Popenoe, 1988).

Jurassic depostion along the margin was dominated by carbonate accumulation in the Blake Plateau and carbonate-terrigenous deposition in the Carolina trough. A gigaplatform/reef system extended from the Bahamas north to Baltimore Canyon trough, and served to limit the amount of sediments reaching the continental slope/rise and abyssal plain (Poag, 1991).

During the Early Cretaceous, carbonate deposition slowed and reef development ended from north to south. By the end of Cretaceous time, rising sea level and subsidence produced the deep water Blake Plateau, which became a sediment-starved region characterized by biogenic and authigenic deposition (Dillon and Popenoe, 1988).

Cenozoic time has been dominated by erosion processes and the development of widespread regional unconformities. Ocean currents such as the Suwanee, Gulf Stream, and Deep Western Atlantic Boundary currents were initiated. Changes in sea level have caused the Gulf Stream to migrate across the Blake Plateau, affecting sediment deposition patterns. The most notable among the deposits related to these variable currents is the Blake Outer Ridge,

Figure 1: Perspective illustration of the physiography of the U.S. continental margin between Cape Hatteras (right edge of figure) and Bahamas (left side of figure). In the physiographic diagram, the coast line for the U.S. is shown (stippling), but not that for the Bahamas. 


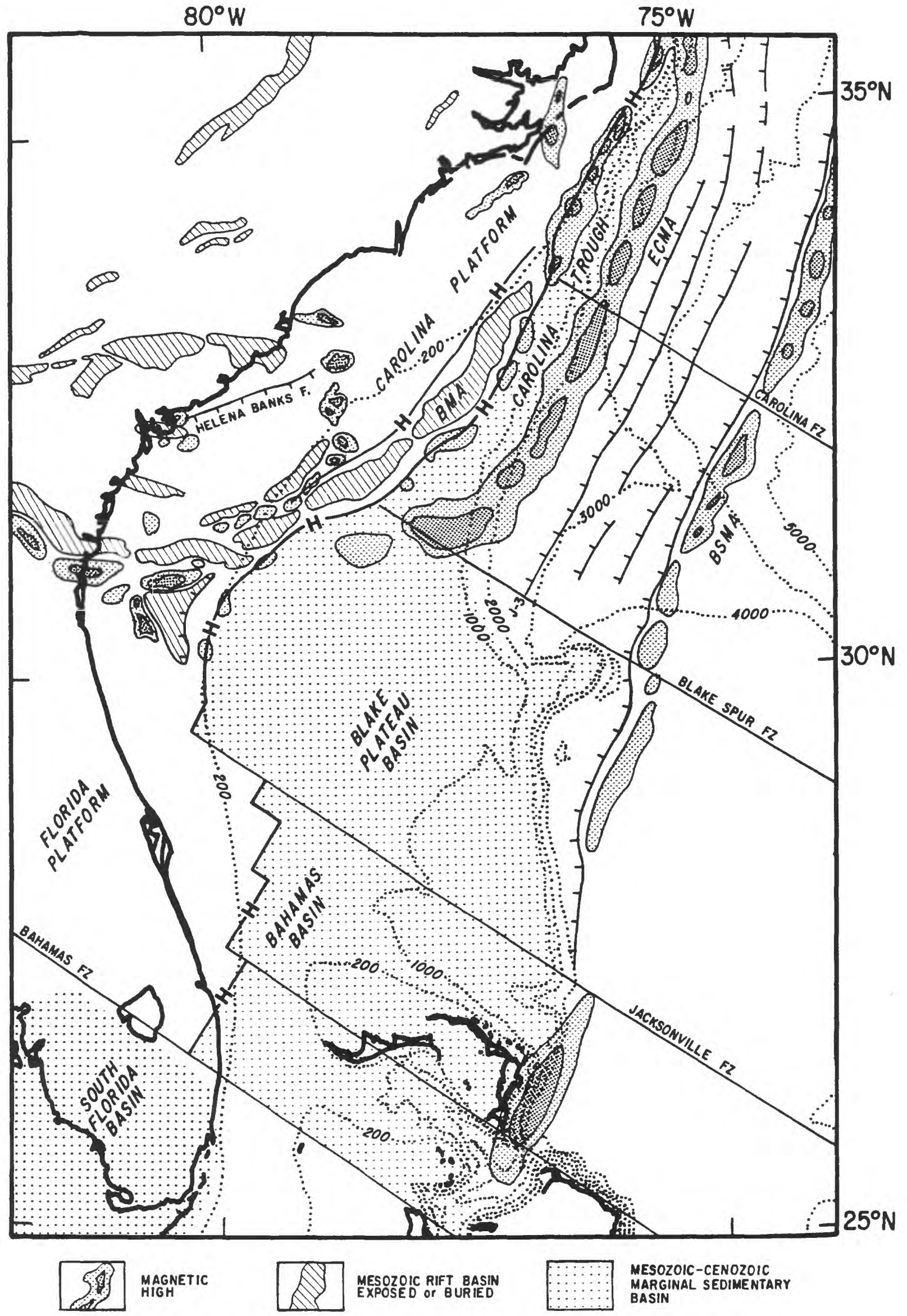


a large sedimentary drift formed off the Carolina trough in post-Oligocene time (Bryan, 1970; Markl et al., 1970; Markl and Bryan, 1983; Mountain and Tucholke, 1985).

One of the most notable features that has modified the stratigraphy through time is salt migration into diapirs in the Carolina trough. Evaporites were among the earliest deposits in late rift and early post-rift formation of the margin, and these deposits have mobilized upward through the overlying sediments to form a linear chain of diapirs (Dillon et al., 1983). Few of the diapirs reach the sea floor and they appear to be confined to the seaward edge of the Carolina trough. None are known in the Blake Plateau basin.

Faults have also modified the region. Growth faults are associated with salt diapirism near the shelf edge (Dillon et al., 1983). Large normal faults are interpreted near the edge of the Blake Escarpment on several profiles (Hutchinson et al., 1995). Extensive mapping in the inner shelf has revealed the existence of young neotectonic faults (Behrendt et al., 1983) which could be related to ongoing low-level seismicity in the southeastern United States (Behrendt and Yuan, 1986).

Two additional stratigraphic features occur on the continental margin which have not been specifically mapped in this data base project: gas hydrates, which are extensive frozen methane deposits found primarily within the shallow subsurface deposits of the Carolina trough (e.g., Dillon et al., 1994, 1995); and manganese nodule pavements, which are restricted in outcrop to the Blake Plateau (Popenoe, 1993). Gas hydrates are associated with a strong reflection that is subparallel to the sea floor in water depths greater than about $500 \mathrm{~m}$ (e.g., Kvenvolden, 1993). This reflection has been extensively mapped elswhere and occurs primarily in Miocene and younger deposits (e.g., Dillon et al., 1995). The hard manganesenodule pavement at the surface of the Blake Plateau contributes to the strong bottom reflection and peg-leg multiple reflections that characterize seismic data from the Blake Plateau.

\section{Multichannel Data}

\section{DATA}

The multichannel stratigraphic and velocity data used to generate the gridded database are described in detail in Hutchinson et al. (1995). The data consist of about $7600 \mathrm{~km}$ of 24 and 36-fold multichannel seismic data that were collected separately by five contractors between 1974 and 1979 (Figure 3, Table 1). The quality of the multichannel record sections and velocity scans varies between the five data sets; the data from the Carolina trough are generally superior to those from the Blake Plateau (Hutchinson et al., 1995).

Figure 2: Simplified tectonic map of the continental margin south of Cape Hatteras. Abbreviations are $H$ - hinge zone; BMA - Brunswick magnetic anomaly; ECMA - East Coast Magnetic Anomaly; BSMA - Blake Spur magnetic anomaly. The map shows the positions of synrift basins on land, major fracture zones, major magnetic anomalies, the hinge zone, the positions of the deeply subsided offshore sedimentary basins (Carolina trough and Blake Plateau), large faults, and bathymetry in meters (dotted lines). Modified from Klitgord et al. (1988). 


\section{Multichannel Profile Locations}

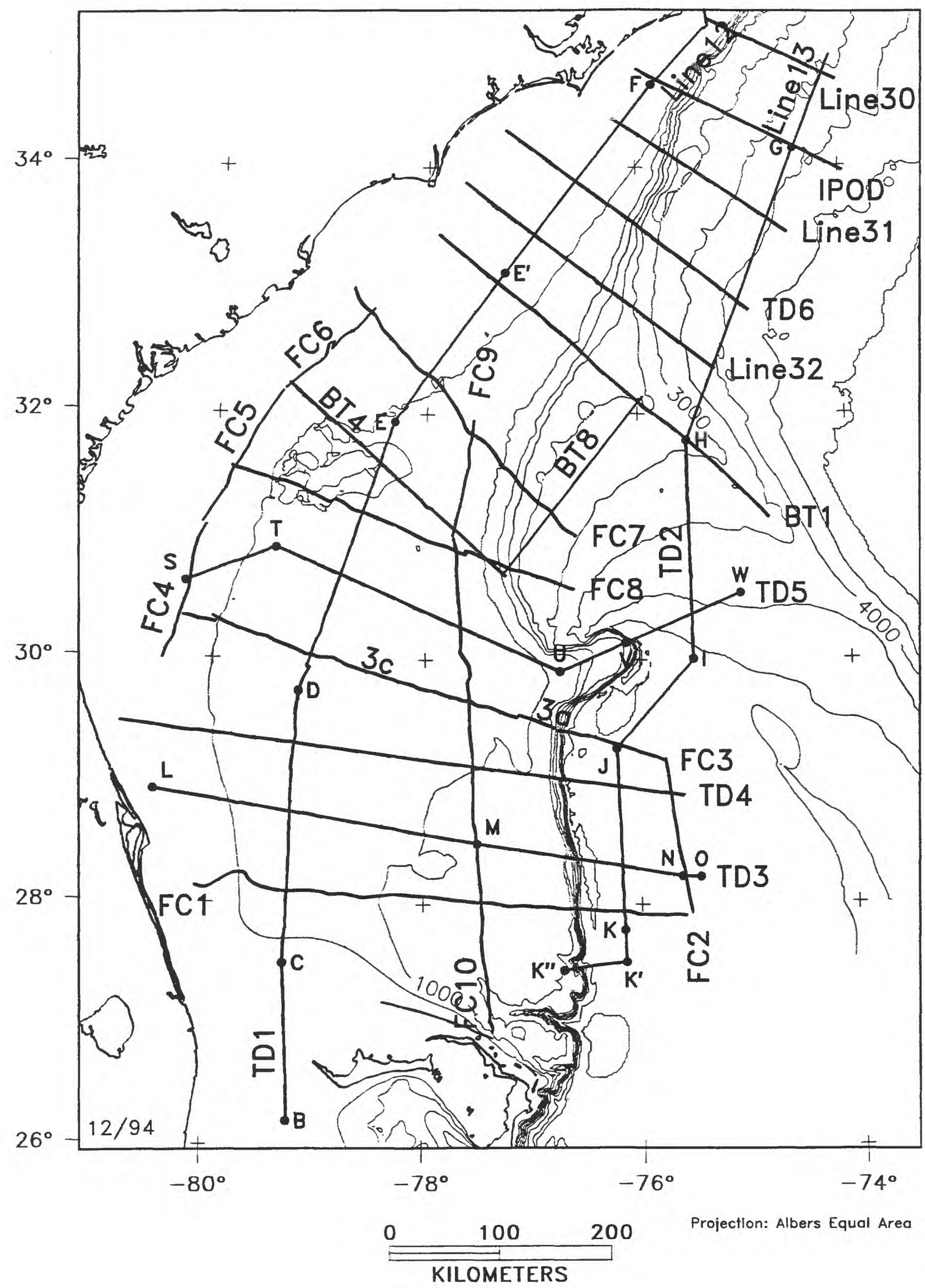




\section{Digital Stratigraphic Data}

The stratigraphy was interpreted and digitized for 18 horizons (Table 2): 8 in the Cenozoic (including the sea floor), 5 in the Cretaceous, and 5 in the Jurassic. Each horizon represents an allostratigraphic discontinuity (Poag and Ward, 1993) and is assigned a number from 1 at the sea floor to 190, the deepest identifiable postrift horizon. These numbers are arbitrary and have no geologic or age significance but they facilitate labelling digital plots and maps of the horizons and units. Assigned age and geologic interpretation of each horizon are given in Table 2. The stratigraphic interpretation was calibrated by eight deep wells, 12 shallow borings, 10 Alvin submersible dives along 3 transects of the Blake Escarpment, and numerous dredge samples (Figure 4, Table 3). The digital stratigraphy is sampled at $250-\mathrm{m}$ intervals along each line, which is equivalent to 5 shot points. The nomenclature and numbering convention used in this data base are identical to that used by Klitgord and Schneider (1994) and Klitgord et al. (1994) for the data base north of Cape Hatteras.

Each numbered discontinuity represents the surface at the base of a unit. Properties that characterize a unit (e.g., interval velocity or thickness) refer to the unit immediately above the numbered discontinuity. In this convention, we always refer to material that exists above a reflector, since the original material below a reflector may have been eroded. This is illustrated in Figure 5 which shows an example where the surface represented by reflector 60 (base of Oligocene) merges with reflector 70 (base of Paleocene-Eocene). We call the reflector at the base of Oligocene reflector 60 and assume that the surface represented by reflector 70 is not present in the middle of the profile. Prominent geologic boundaries that form erosional unconformities at the tops of units (such as the top of Cretaceous) often consist of several reflectors (reflector 70 at the sides of the figure and reflector 60 in the center of Figure 5). This convention differs from standard reference to the tops of geologic units, but eliminates ambiguity in defining units and bounding horizons as well as simplifying the stratigraphic framework. Representative seismic sections illustrating the stratigraphy are shown in Figures 6 and 7.

\section{Digital Velocity Data}

The interval velocity data for each stratigraphic unit is calculated from stacking velocities digitized from the multichannel seismic reflection data using the Dix equation (Dix, 1955) after interpolation along each stratigraphic horizon (Hutchinson et al., 1995). Locations of original velocity-scan points are shown in Figure 8. Smoothing of the velocity data to remove unrealistic lateral velocity variations resulted in a likely overestimate of velocity by as much as $20 \%$ in the landward-most $20 \mathrm{~km}$ of each line (Hutchinson et al., 1995). Velocities were checked against independent refraction data, wide-angle reflection data, and sonic logs from wells, where available (Figure 9, Table 4). Details of these comparisons are given in Hutchinson et al. (1995).

\section{Lithology Data}

Lithologic interpretations were completed for each unit (Popenoe, unpublished maps) using seismic facies analysis (e.g., Payton, 1977), available sample information (Table 3)

Figure 3: Locations of multichannel seismic reflection profiles used in constructing the gridded database. Letters $A-W$ on lines TD-1 to TD-5 indicate subdivisions of each line. 


\section{Sample and Profile Locations}

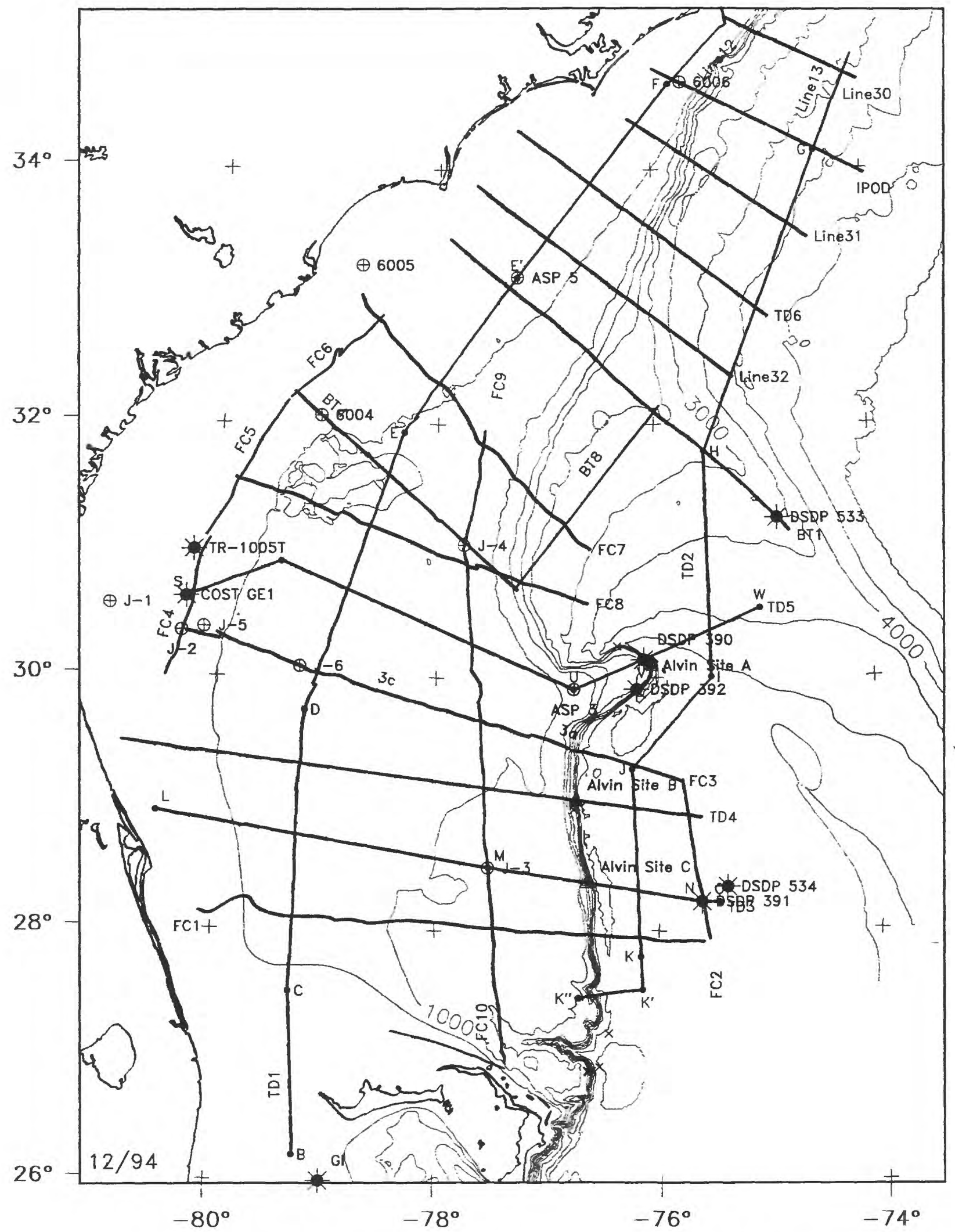

LEGEND

- Drill Holes

$¥$ Shallow Borings

$\times$ Dredge Samples

$\triangle$ Alvin Dive Sites

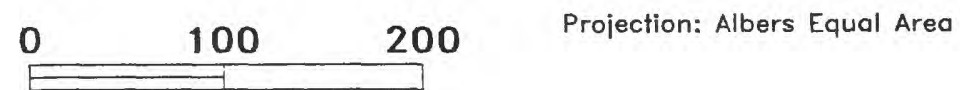

KILOMETERS 
augmented by many shallow cores and sea-floor grab samples (Popenoe 1985), and interpretations from high-resolution single-channel seismic-reflection surveys (Popenoe, 1985, and references therein). The boundaries on these maps were then digitized for use in compiling the data base.

\section{Surface Grain Size Data}

Grain-size information (phi values) for the surface sediments (Figure 10) are from the USGS surface sediment data base representing more than 40 years of surficial sampling (Hathaway, 1971; Hathaway et al., 1979; Hathaway, 1994) supplemented by two grain-size determinations for the abyssal plain supplied from the library of the Naval Oceanographic Office (Kekko et al., 1992). These values are used later in this report to estimate surface attenuation, which is then used as the starting point for estimating p- and s-wave attenuation in each underlying sedimentary unit (Stoll, 1980, 1985).

TABLE 1: Descriptive Information about Multichannel Profiles

\begin{tabular}{|c|c|c|c|c|c|}
\hline \multirow[t]{2}{*}{ DATA } & \multicolumn{2}{|c|}{ Acquisition } & \multicolumn{2}{|c|}{ Processing } & \multirow{2}{*}{$\begin{array}{l}\text { Vel. } \\
\text { Picks } \\
(\mathrm{km})\end{array}$} \\
\hline & Company & Year & Company & Year & \\
\hline IPOD $^{1}$ & Digicon & 1974 & GSI & 1975 & 3 \\
\hline BT & GSI & 1974 & GSI & 1974 & 3.2 \\
\hline $\mathrm{FC}$ & $\begin{array}{c}\text { Institute } \\
\text { Francoise du } \\
\text { Petrole (IFP) }\end{array}$ & 1975 & $\begin{array}{l}\text { Compagne } \\
\text { Generale de } \\
\text { Geophysique }\end{array}$ & 1975 & 10.8 \\
\hline TD & Teledyne & 1977 & $\begin{array}{c}\text { Teledyne } \\
\text { USGS }^{2}\end{array}$ & $\begin{array}{l}1978 \\
1979 \\
\end{array}$ & $\begin{array}{l}3 \\
5 \\
\end{array}$ \\
\hline GSI & GSI & 1978 & GSI & 1978 & 3 \\
\hline
\end{tabular}

1 The 45-km long segments of lines 12 and 13 used in this compilation are equivalent to the IPOD data in quality. They were acquired by Digicon in 1975 and are described in Klitgord et al. (1994).

${ }^{2}$ Lines TD-6, TD-2GH, and TD-2HI were processed by USGS in 1978. There are no records of the contractor ever providing original processing for these lines.

Figure 4: Locations of multichannel profiles and sample information used to constrain interpretations of the multichannel data. Bathymetry contoured at 500-m intervals. 


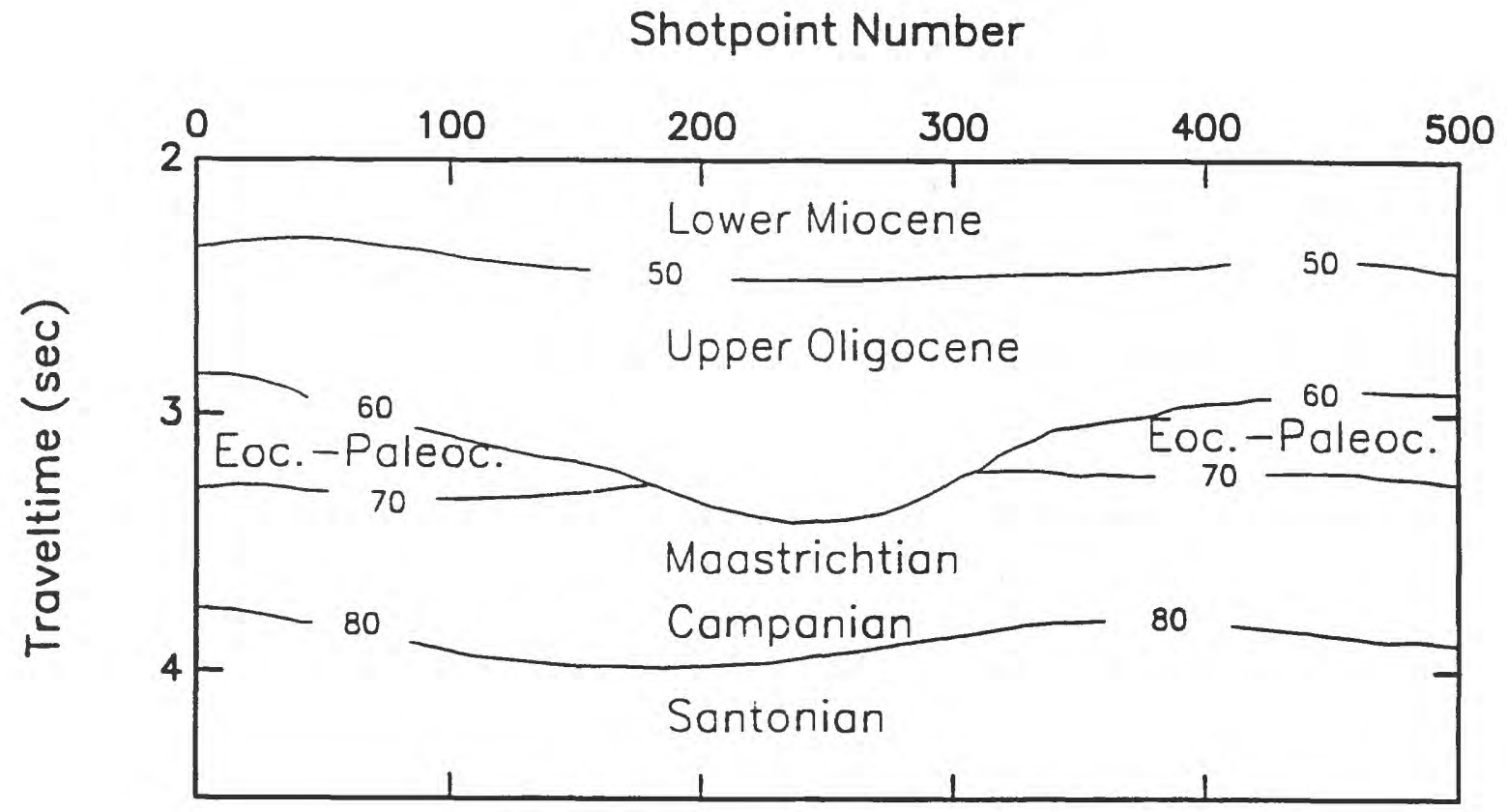

Figure 5: Hypothetical reflection profile showing the terminology and conventions used for numbering stratigraphic horizons. Because reflectors are defined at the base of a unit, the corresponsindg top of a unit can consist of several numbered horizons. For example, reflector 60 is always the base of the Oligocene, but the top of Cretaceous in this diagram will be reflector 70 at the edges, and reflector 60 in the center. (From Klitgord and Schneider, 1994). 
TABLE 2: U.S. Atlantic Margin Seismic Stratigraphy ${ }^{1}$

\begin{tabular}{|r|l|l||}
\hline $\begin{array}{r}\text { Reflector } \\
\text { Number }\end{array}$ & \multicolumn{1}{|c|}{ Geologic Surface } & \multicolumn{1}{|c|}{ Common Name $^{3}$} \\
\hline 1 & Base water column & Seafloor \\
\hline 20 & Base Quaternary & \\
\hline 30 & Base Pliocene & \\
\hline 40 & Base Upper Miocene & \\
\hline 45 & Base Middle Miocene & Mid-Miocene Unconformity \\
\hline 50 & Base Lower Miocene & \\
\hline 60 & Base Upper Oligocene & Mid-Oligocene Unconformity \\
\hline 70 & Base Paleocene/Eocene & Top Cretaceous \\
\hline 80 & Base Campanian/Maastrichtian & Horizon A* in Deep Sea \\
\hline 90 & Base Coniacian/Santonian & Late Cenomanian Unconformity \\
\hline 105 & Base Aptian/Albian/Cenomanian/ Turonian & Mid Cretaceous Unconformity \\
\hline 110 & Base Barremian & Horizon $\beta$ in Deep Sea \\
\hline 120 & Base Berriasian/Valanginian/ Hauterivian & Top Jurassic \\
\hline 140 & Base Kimmeridgian/Tithonian & \\
\hline 150 & Base Oxfordian & Top Middle Jurassic \\
\hline 170 & Base Upper Bathonian/Callovian & \\
\hline 180 & Base Bajocian/Lower Bathonian & \\
\hline 190 & Base Aalenian & Postrift Unconformity \\
\hline & & \\
\hline \hline
\end{tabular}

${ }^{1}$ This is the same stratigraphy used by Klitgord et al. (1994) for the continental margin north of Cape Hatteras, except for horizons 100 (Base Cenomanian/Turonian), and 130 (Base Tithonian). These two horizons were not mapped separately in the area south of Hatteras.

${ }^{2}$ Numbers have no geologic significance and are used only as an identifier in the digital data base. They correspond to the same geologic horizons throughout the data set.

3 Names commonly encountered in the literature. 

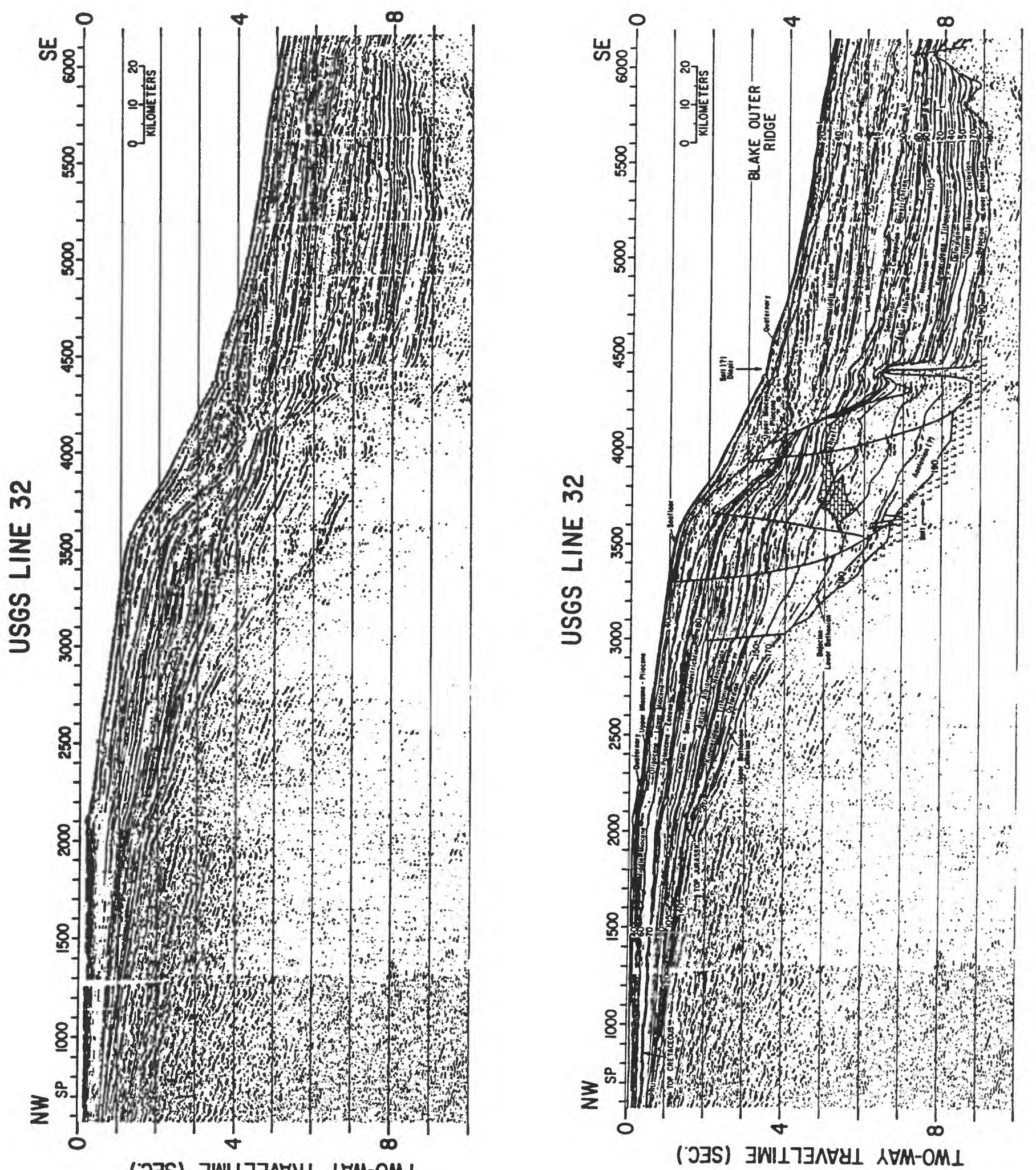


\section{SPATIAL ALIASING AND LIMITATIONS}

An inherent sampling bias characterizes the multichannel seismic data from the southeast U.S. continental margin: the sampling interval along dip line is $250 \mathrm{~m}$ whereas the distance between adjacent lines is $30-40 \mathrm{~km}$. The strike lines connecting the dip lines are spaced even further apart, $100-150 \mathrm{~km}$. This spatial aliasing limits the lateral resolution of geologic features that can be estimated in those areas of the continental margin that lie between the strike and dip lines. For this reason, all maps based on the information from the multichannel seismic profiles show the locations of the tracklines. Hence, the artifacts generated by the gridding process in areas of no data control can be readily identified.

\section{Non-Two-Dimensional Features}

The widely-spaced tracks also pose challenges for correctly imaging the geometry and morphology of certain non-two-dimensional features of the continental margin. For example, line TD-5 runs along the axis of the Blake Spur at the north end of the Blake Plateau, but no other lines cross the Spur. This lack of crossing information virtually renders impossible any accurate gridding of the shape of the Blake Spur. To a lesser extent, the coverage of the Blake Outer Ridge poses similar problems. The strategy we adopted to minimize this undersampling is addressed in the section "Construction of Grids".

\section{Two-Dimensional Discontinuities}

Because of the spatial aliasing, some two-dimensional features (e.g., large discontinuities) are not properly imaged in standard gridding algorithms. The Blake Escarpment, where water depths increase abruptly from about $1000 \mathrm{~m}$ to about $5000 \mathrm{~m}$, is an example of one of these discontinuities. The gridding fails to reproduce these linear features using assumptions of either minimum or maximum tension (e.g., Smith and Wessel, 1990) which results in excessive scalloping of contours (Figures 11 and 12). Computational ease required us to choose a single gridding algorithm for all grids, which was the standard miminum (i.e., zero) tension gridding.

A qualitative way to evaluate the accuracy of the gridding algorithm is to grid the observed data for bathymetry, which can them be compared with independent measurements for this part of the margin (NOS, 1986). The results of gridding the bathymetry directly from the multichannel coverage (Figure 12) show how the Blake Spur, the Blake Escarpment, and Blake Outer Ridge are undersampled to image these features accurately.

A second type of two-dimensional discontinuity that is poorly imaged during gridding is a narrow, linear feature, such as a fault or reef complex. The grid spacing of 5 minutes (about $9 \times 8 \mathrm{~km}$ ) makes it impossible to image features that are narrower or shorter than the grid-node interval. Many of these features for the continental margin south of Cape Hatteras are well documented in exisiting publications (e.g., Behrendt et al. 1983; Behrendt and Yuan 1986; Dillon and Popenoe, 1988; Poag, 1991).

Figure 6: Representative multichannel line 32 across the Carolina trough showing uninterpreted profile data (upper) and numbered stratigraphic horizons, ages, faults, major reef structure, and inferred salt deposits (lower). PRU - post rift unconformity. 

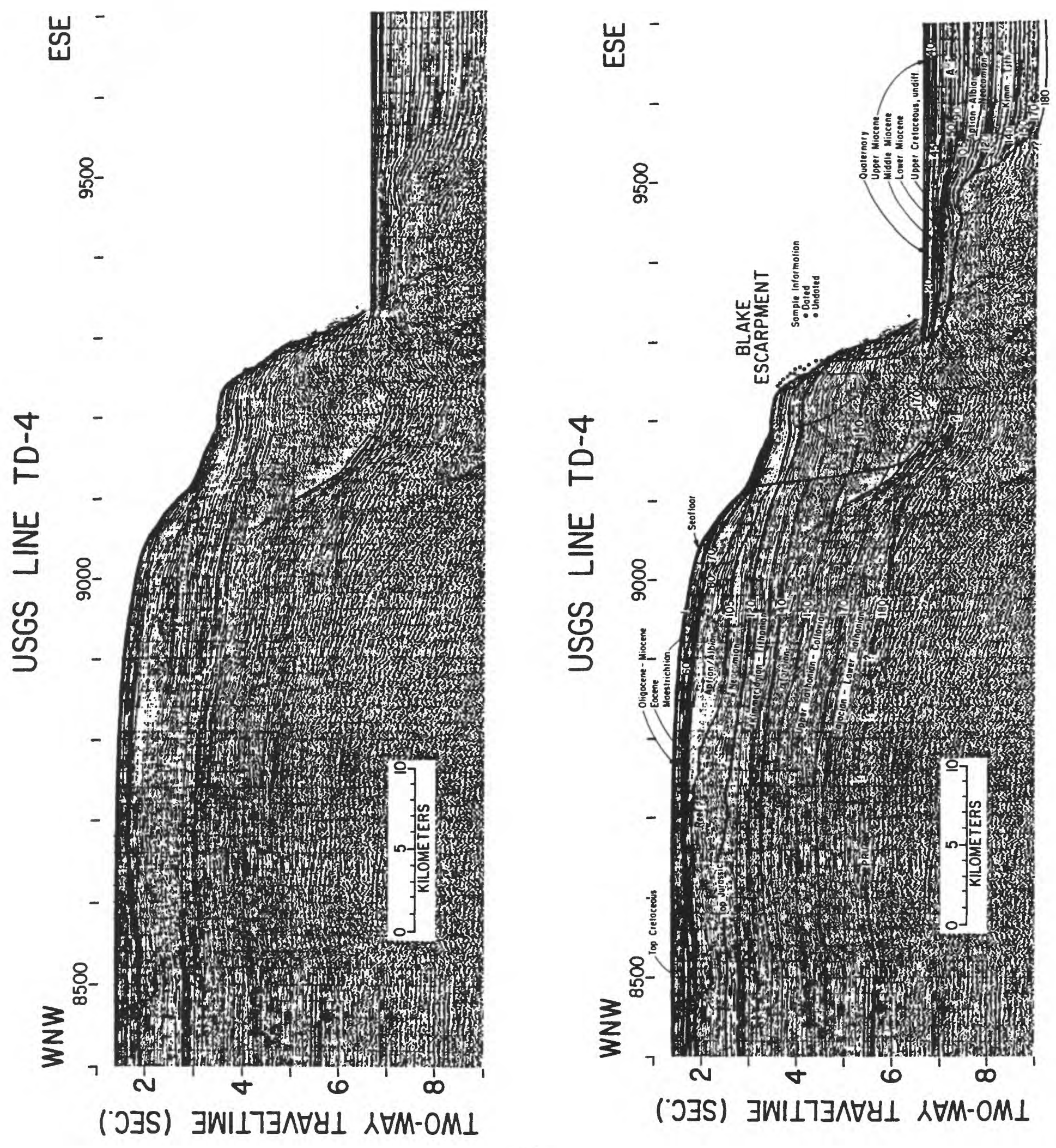


\section{Point features}

The Carolina continental slope is well known for a linear chain of diapirs (Dillon et al., 1983) that parallels the margin (Figure 13). These features are typically less than $3 \mathrm{~km}$ across, and, like many faults, are unresolvable at the gridding size of 5 minutes. Diapirs are shown on the profile data as interruptions in reflecting horizons (e.g., Figure 5), but are not otherwise digitized or included in the data base. Most of these diapirs occur more than $2 \mathrm{~km}$ beneath the sea floor and generally affect horizons Late Cretaceous and older in age.

Figure 7: Representative multichannel seismic reflection profile TD-4 for part of the Blake Plateau and Blake Escarpment showing uninterpreted record (upper) and the same profile with numbered stratigraphic horizons, ages, faults, and sample information (lower). PRU-post rift unconformity. 
TABLE 3: Locations of Well and Other Samples

\begin{tabular}{|c|c|c|c|}
\hline \multirow[t]{2}{*}{ Name } & \multicolumn{2}{|c|}{ Location } & \multirow[t]{2}{*}{ Comment } \\
\hline & Latitude & Longitude & \\
\hline COST GE-1 & $30^{\circ} 37.128^{\prime} \mathrm{N}$ & $80^{\circ} 17.986^{\prime} \mathrm{W}$ & Deep wells/logs \\
\hline DSDP 390 & $30^{\circ} 08.54^{\prime} \mathrm{N}$ & $76^{\circ} 06.74^{\prime} \mathrm{W}$ & Scholle (1979) \\
\hline DSDP 391 & $28^{\circ} 13.73^{\prime} \mathrm{N}$ & $75^{\circ} 36.88^{\prime} \mathrm{W}$ & Benson, Sheridan et al. (1978) \\
\hline DSDP 392 & $29^{\circ} 54.63^{\prime} \mathrm{N}$ & $76^{\circ} 10.68^{\prime} \mathrm{W}$ & Sheridan, Gradstein et al. (1983) \\
\hline DSDP $533^{1}$ & $31^{\circ} 15.60^{\prime} \mathrm{N}$ & $74^{\circ} 52.19^{\prime} \mathrm{W}$ & Dillon and Popenoe (1988) \\
\hline DSDP 534 & $28^{\circ} 20.63^{\prime} \mathrm{N}$ & $75^{\circ} 22.89^{\prime} \mathrm{W}$ & Tator and Hatfield $(1975 a, 1975 b)$ \\
\hline TR-1005 & $30^{\circ} 59.567^{\prime} \mathrm{N}$ & $80^{\circ} 14.638^{\prime} \mathrm{W}$ & \\
\hline Great Isaac 1 & $26^{\circ} 02^{\prime} \mathrm{N}$ & $79^{\circ} 05^{\prime} \mathrm{W}$ & \\
\hline $\mathrm{J}-1$ & $30^{\circ} 33.0^{\prime} \mathrm{N}$ & $81^{\circ} 00.0^{\prime} \mathrm{W}$ & JOIDES Boreholes \\
\hline $\mathrm{J}-2$ & $30^{\circ} 21.0^{\prime} \mathrm{N}$ & $80^{\circ} 20.0^{\prime} \mathrm{W}$ & No logs \\
\hline $\mathrm{J}-3$ & $28^{\circ} 30.0^{\prime} \mathrm{N}$ & $77^{\circ} 31.0^{\prime} \mathrm{W}$ & Bunce et al. (1965) \\
\hline $\mathrm{J}-4$ & $31^{\circ} 03.0^{\prime} \mathrm{N}$ & $77^{\circ} 45.0^{\prime} \mathrm{W}$ & Charm et al. (1969) \\
\hline $\mathrm{J}-5$ & $30^{\circ} 23.0^{\prime} \mathrm{N}$ & $80^{\circ} 08.0^{\prime} \mathrm{W}$ & \\
\hline$J-6$ & $30^{\circ} 05.0^{\prime} \mathrm{N}$ & $79^{\circ} 15.0^{\prime} \mathrm{W}$ & \\
\hline ASP 3 & $29^{\circ} 54.7^{\prime} \mathrm{N}$ & $76^{\circ} 44.6^{\prime} \mathrm{W}$ & Atlantic Slope Project \\
\hline ASP 5 & $33^{\circ} 09.7^{\prime} \mathrm{N}$ & $77^{\circ} 15.5^{\prime} \mathrm{W}$ & Poag (1978) \\
\hline 6002 & $31^{\circ} 08.57^{\prime} \mathrm{N}$ & $80^{\circ} 31.05^{\prime} \mathrm{W}$ & USGS Drilling Program \\
\hline 6004 & $32^{\circ} 03.98^{\prime} \mathrm{N}$ & $79^{\circ} 05.86^{\prime} \mathrm{W}$ & No logs \\
\hline 6005 & $33^{\circ} 15.10^{\prime} \mathrm{N}$ & $78^{\circ} 44.08^{\prime} \mathrm{W}$ & Hathaway et al. (1979) \\
\hline 6006 & $34^{\circ} 41.40^{\prime} \mathrm{N}$ & $75^{\circ} 43.00^{\prime} \mathrm{W}$ & Poppe (1981) \\
\hline Site A Alvin-1054 & $30^{\circ} 06.0^{\prime} \mathrm{N}$ & $76^{\circ} 02.0^{\prime} \mathrm{W}$ & Alvin Dives on Blake Escarpment \\
\hline Alvin-1055 & $30^{\circ} 07.0^{\prime} \mathrm{N}$ & $76^{\circ} 02.0^{\prime} \mathrm{W}$ & Dillon et al. (1987) \\
\hline Alvin- 1056 & $30^{\circ} 08.0^{\prime} \mathrm{N}$ & $76^{\circ} 03.0^{\prime} \mathrm{W}$ & Dillon et al. (1988) \\
\hline Alvin- 1057 & $30^{\circ} 08.0^{\prime} \mathrm{N}$ & $76^{\circ} 02.0^{\prime} \mathrm{W}$ & \\
\hline Site B Alvin- 1058 & $29^{\circ} 02.0^{\prime} \mathrm{N}$ & $76^{\circ} 43.0^{\prime} \mathrm{W}$ & \\
\hline Alvin-1059 & $29^{\circ} 02.0^{\prime} \mathrm{N}$ & $76^{\circ} 44.0^{\prime} \mathrm{W}$ & \\
\hline Alvin-1060 & $29^{\circ} 03.0^{\prime} \mathrm{N}$ & $76^{\circ} 44.0^{\prime} \mathrm{W}$ & \\
\hline Site C Alvin-1061 & $28^{\circ} 23.0^{\prime} \mathrm{N}$ & $76^{\circ} 36.0^{\prime} \mathrm{W}$ & \\
\hline Alvin- 1062 & $28^{\circ} 24.0^{\prime} \mathrm{N}$ & $76^{\circ} 38.0^{\prime} \mathrm{W}$ & \\
\hline Alvin-1063 & $28^{\circ} 23.0^{\prime} \mathrm{N}$ & $76^{\circ} 39.0^{\prime} \mathrm{W}$ & \\
\hline E-9-66-7 & $28^{\circ} 57.5^{\prime} \mathrm{N}$ & $76^{\circ} 45.0^{\prime} \mathrm{W}$ & Dredge Samples on Blake Escarpment \\
\hline E-9-66-4 & $28^{\circ} 59.0^{\prime} \mathrm{N}$ & $76^{\circ} 43.5^{\prime} \mathrm{W}$ & Heezen and Sheridan (1966) \\
\hline E-9-66-3 & $28^{\circ} 59.5^{\prime} \mathrm{N}$ & $76^{\circ} 45.0^{\prime} \mathrm{W}$ & Sheridan et al. (1971) \\
\hline E-9-66-12 & $30^{\circ} 15.0^{\prime} \mathrm{N}$ & $76^{\circ} 21.0^{\prime} \mathrm{W}$ & \\
\hline E-11067 & $27^{\circ} 11.0^{\prime} \mathrm{N}$ & $76^{\circ} 27.0^{\prime} \mathrm{W}$ & \\
\hline E-11070 & $26^{\circ} 55.0^{\prime} \mathrm{N}$ & $76^{\circ} 32.0^{\prime} \mathrm{W}$ & \\
\hline E-11072 & $26^{\circ} 52.5^{\prime} \mathrm{N}$ & $76^{\circ} 38.0^{\prime} \mathrm{W}$ & \\
\hline E-11073 & $26^{\circ} 53.0^{\prime} \mathrm{N}$ & $76^{\circ} 38.2^{\prime} \mathrm{W}$ & \\
\hline E-13548 & $26^{\circ} 53.0^{\prime} \mathrm{N}$ & $76^{\circ} 36.0^{\prime} \mathrm{W}$ & \\
\hline E-13549 & $26^{\circ} 53.0^{\prime} \mathrm{N}$ & $76^{\circ} 38.0^{\prime} \mathrm{W}$ & \\
\hline
\end{tabular}

${ }^{1}$ Information from DSDP 533 and 534 was used instead of DSDP holes 102, 103, 104 (Hollister, Ewing et al., 1972) because of better line ties to BT-1. 
TABLE 4: Independent Velocity Information

\begin{tabular}{|c|c|c|c|}
\hline ID & $\begin{array}{l}\text { Crossing } \\
\text { MCS line }\end{array}$ & Reference & Comment \\
\hline COST GE-1 & TD-5 & Anderson and Taylor (1979) & Sonic Log \\
\hline DSDP 391 & TD-3 & Leg 44 Science Party (1978) & Physical Properties \\
\hline 72 & FC-4 & Sheridan et al. (1988) & 11-55 of Hersey et al. (1959) \\
\hline $\mathrm{BA}-3$ & FC-4 & Holbrook et al. (1994) & \\
\hline 78 & FC-5 & Sheridan et al. (1988) & 12-55 of Hersey et al. (1959) \\
\hline 67 & FC-5 & Sheridan et al. (1988) & 10-54 of Hersey et al. (1959) \\
\hline 16 & TD-1 & Sheridan et al. (1988) & 3-56 of Hersey et al. (1959) \\
\hline 124 & TD-1 & Sheridan et al. (1988) & 29-55 of Hersey et al. (1959) \\
\hline 11 & TD-1 & Sheridan et al. (1988) & 2-56 of Hersey et al. (1959) \\
\hline $\mathrm{BA}-6$ & TD-1 & Holbrook et al. (1994) & \\
\hline 2301 & TD-1 & Dowling (1968) & also Dillon and McGinnis (1983) \\
\hline 83 & TD-1 & Sheridan et al. (1988) & 13-54 of Hersey et al. (1959) \\
\hline 219 & FC-10 & Sheridan et al. (1988) & 99 of Sheridan et al. (1966) \\
\hline 127 & FC-10 & Sheridan et al. (1988) & 30-55 of Hersey et al. (1959) \\
\hline 144 & FC-9 & Sheridan et al. (1988) & 36-55 of Hersey et al. (1959) \\
\hline 146 & BT-8 & Sheridan et al. (1988) & 37-55 of Hersey et al. (1959) \\
\hline $\mathrm{BA}-6$ & BT-8 & Holbrook et al. (1994) & \\
\hline 131 & TD-2 & Sheridan et al. (1988) & 31-55 of Hersey et al. (1959) \\
\hline 251 & TD-2 & Sheridan et al. (1988) & G15 of Ewing and Ewing (1959) \\
\hline $3-54$ & TD-6 & Hersey et al. (1959) & \\
\hline 77 & TD-6 & Sheridan et al. (1988) & 12-54 of Hersey et al. (1959) \\
\hline $\mathrm{NC}-3$ & Line 32 & Grim et al. (1980) & from Woollard et al. (1957) \\
\hline 77 & Line 32 & Sheridan et al. (1988) & 12-54 of Hersey et al. (1959) \\
\hline 2302 & Line 32 & Dowling (1968) & \\
\hline $\mathrm{L} 2$ & Line 32 & Trehu et al. (1989) & \\
\hline $\mathrm{Ll}$ & Line 32 & Trehu et al. (1989) & \\
\hline 46 & Line 32 & Sheridan et al. (1988) & 7-8 of Houtz and Ewing (1963) \\
\hline 27 & $\mathrm{FC}-7$ & Sheridan et al. (1988) & 4-55 of Hersey et al. (1959) \\
\hline 89 & BT-4 & Sheridan et al. (1988) & 14-55 of Hersey et al. (1959) \\
\hline
\end{tabular}




\begin{tabular}{|l|l|l|l||}
\hline 11 & BT-4 & Sheridan et al. (1959) & 2-56 of Hersey et al. (1959) \\
\hline 11 & FC-8 & Sheridan et al. (1959) & 2-56 of Hersey et al. (1959) \\
\hline 27 & FC-8 & Sheridan et al. (1988) & $4-55$ of Hersey et al. (1959) \\
\hline 72 & TD-5 & Sheridan et al. (1988) & $11-55$ of Hersey et al. (1959) \\
\hline 39 & TD-5 & Sheridan et al. (1988) & $6-55$ of Hersey et al. (1959) \\
\hline 127 & TD-5 & Sheridan et al. (1988) & $30-55$ of Hersey et al. (1959) \\
\hline 251 & TD-5 & Sheridan et al. (1988) & G15 of Ewing and Ewing (1959) \\
\hline 221 & FC-3 & Sheridan et al. (1988) & 102 of Sheridan et al. (1966) \\
\hline 107 & TD-4 & Sheridan et al. (1988) & 19 of Sheridan et al. (1966) \\
\hline 59 & TD-4 & Sheridan et al. (1988) & 9 of Sheridan et al. (1966) \\
\hline 219 & TD-4 & Sheridan et al. (1988) & 99 of Sheridan et al. (1966) \\
\hline 220 & TD-4 & Sheridan et al. (1988) & 100 of Sheridan et al. (1966) \\
\hline 217 & TD-3 & Sheridan et al. (1988) & 97 of Sheridan et al. (1966) \\
\hline Trehu & TD-3 & Trehu (1984, 1985) & \\
\hline 23 & FC-1 & Sheridan et al. (1988) & 4 of Sheridan et al. (1966) \\
\hline 122 & FC-1 & Sheridan et al. (1988) & 24 of Sheridan et al. (1966) \\
\hline \hline
\end{tabular}

Figure 8: Map showing the locations of velocity scan control points. Velocities between these control points were linearly interpolated. 


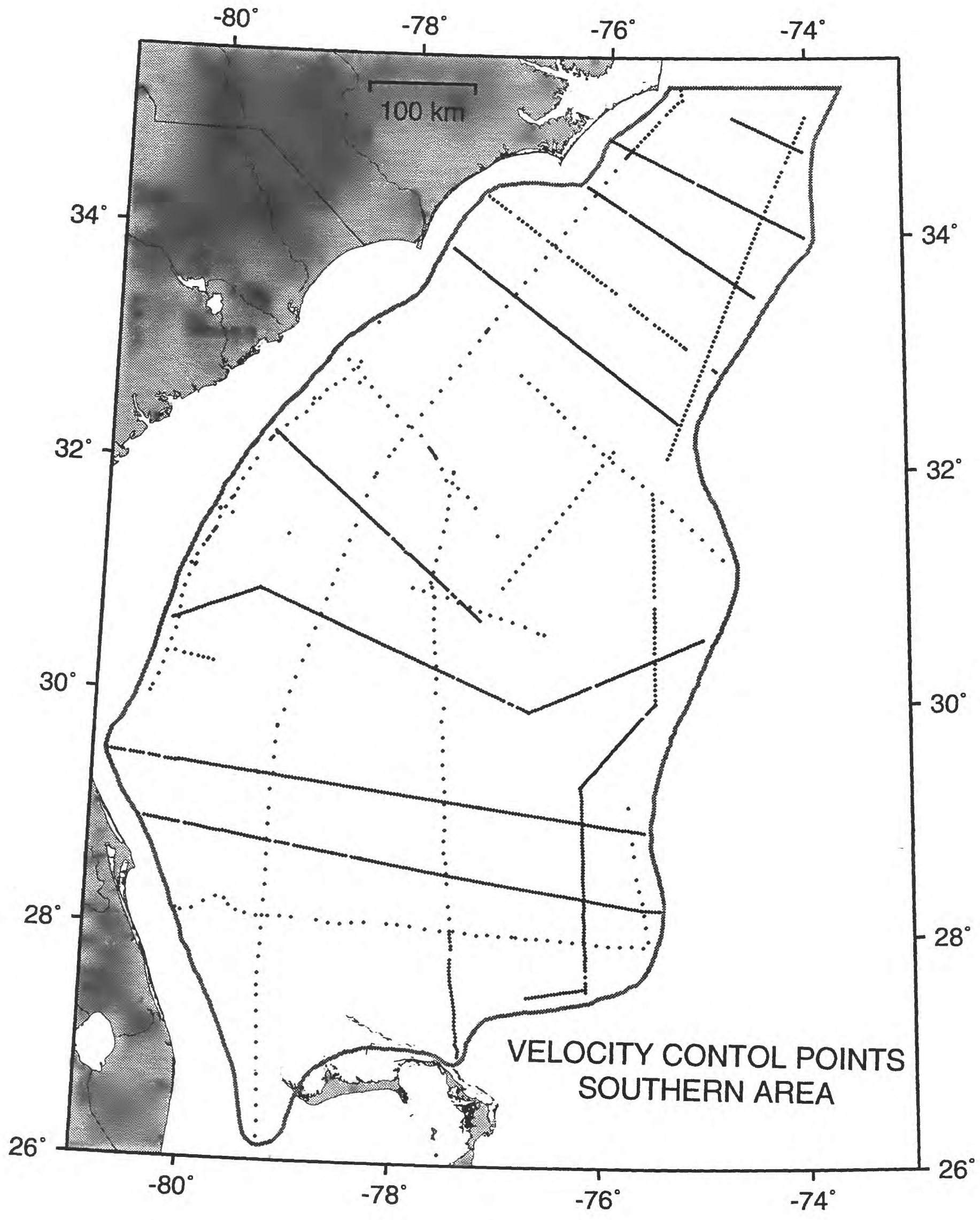


Figure 9: Map showing the locations of independent velocity information from seismic refraction profiles and their intersections with the multichannel seismic reflection tracklines. 


\section{Locations of Refraction Data Sets}

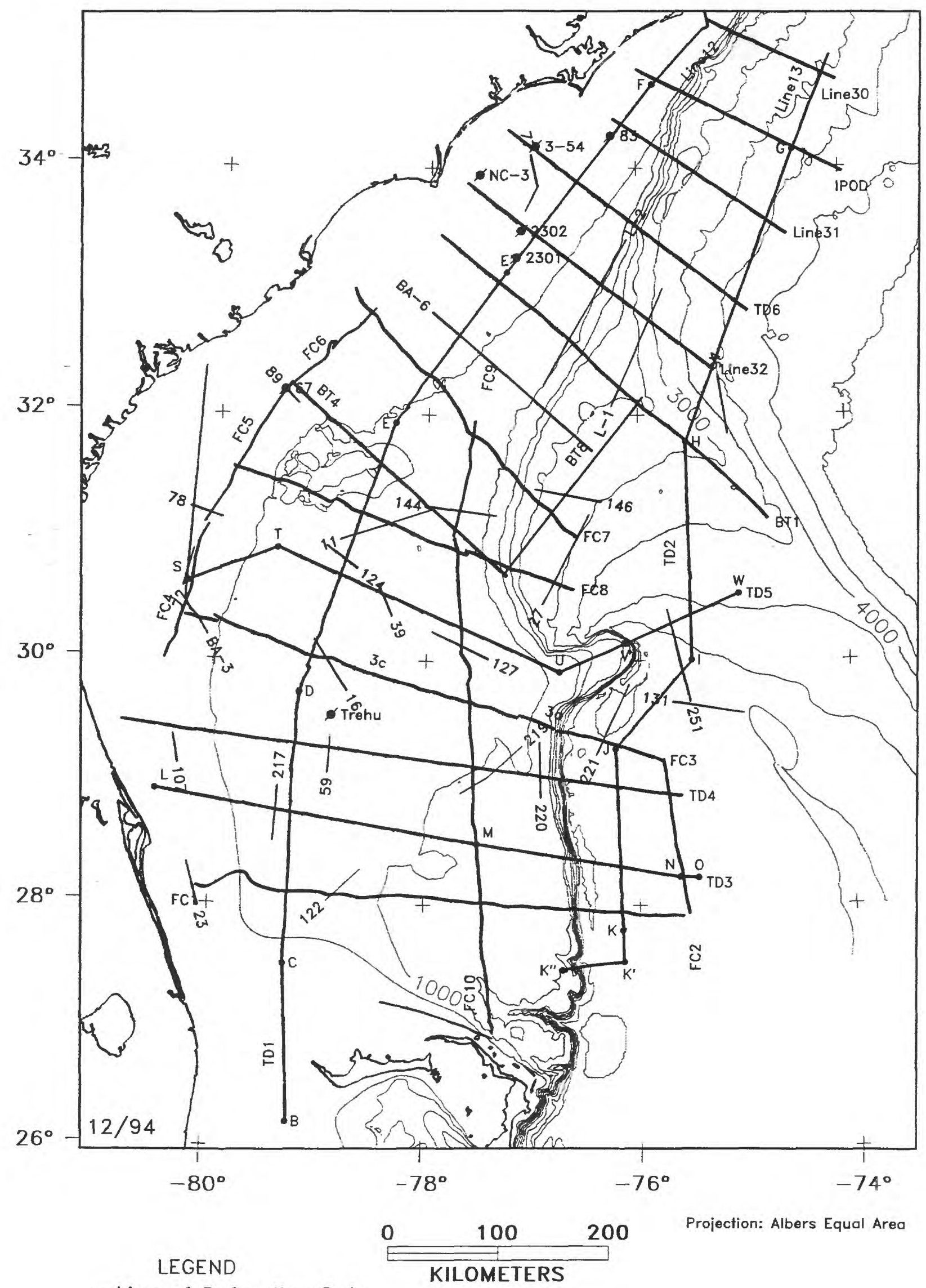

- Line of Refraction Data

- Point of Refraction Data 
Figure 10: Map showing locations and contoured surface grain size information (in units of phi) for the continental margin south of Cape Hatteras. The surface grain size values for core 11 and core 12 are 9.14 and 9.29 phi respectively. 


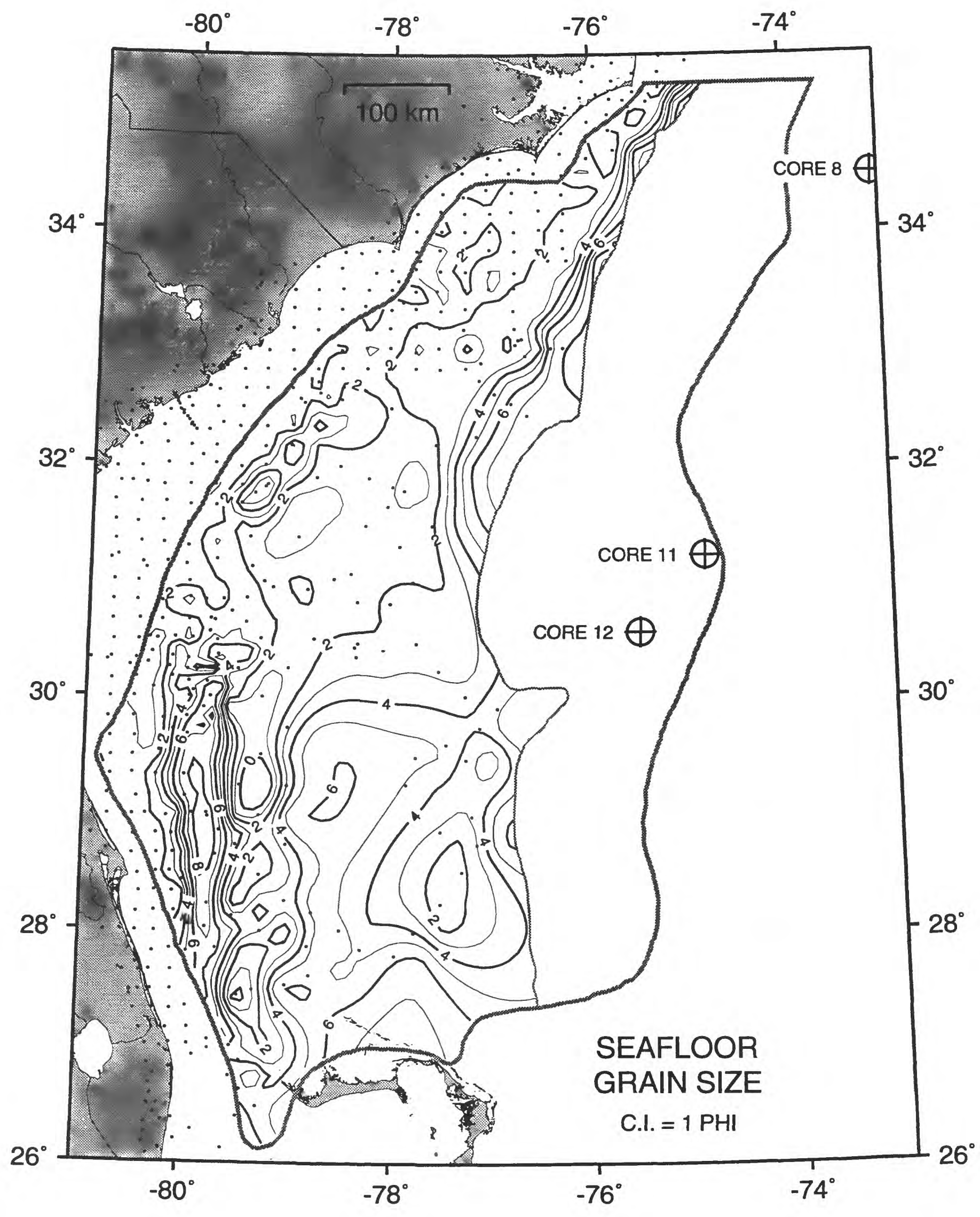




\section{CONSTRUCTION OF GRIDS}

\section{Overview}

All of the grids developed for this project are based on a latitude/longitude grid cell size of 5 minutes, which is approximately $9.23 \mathrm{~km}$ (north/south) by $7.96 \mathrm{~km}$ (east/west). Figure 14 shows the locations of grid nodes within the study area. Table 5 gives selected statistics about each unit. A minimum-curvature cubic-spline technique (Smith and Wessel, 1990) with a tension of zero was used for gridding all data. Because of our convention that the horizon is mapped as the base of a unit, then the existence of horizon $T(n)$ requires that unit $T(n)$ will also exist. Unit $\mathrm{T}(\mathrm{n})$ contains material that, in age, is always between the next younger horizon $T(n-1)$ and $T(n)$. Six grids were generated for each of the 18 numbered horizons:

(a) Isochron: two-way travel time through the unit above $T(n)$ in seconds.

(b) Interval velocity: interval velocity of the unit above $T(n)$ in meters/second.

(c) Thickness: product of one-half the isochron (i.e., time thickness) and velocity grids for the unit above $T(n)$, in meters.

(d) Structure Map - Time: two-way travel time to horizon $T(n)$ from the sea surface, in seconds.

(e) Structure Map - Depth: depth to horizon T(n) from the sea surface, in meters.

(f) Lithology: simple classification of unit above T(n) according to Table 6 .

\section{Polygons}

Polygons (i.e., boundaries) are drawn on each map to show the areal distribution of the data. A master polygon showing the location of the maximum area that could be gridded with the available trackline coverage bounds the grid nodes shown in Figure 14.

In addition, polygons which define the subcrop limits for each unit and horizon are drawn within the master polygon. These individualized polygons define regions where the unit or horizon does not exist, i.e., where values are set to either zero or null, because the unit has been eroded or was never deposited initially. The polygons associated with each horizon and unit were drawn using three types of information: (a) the distribution of data points mapped from the profile data; (b) surficial outcrop locations mapped by Paull et al. (1980), Popenoe(1993), and Popenoe (unpublished map of geologic subcrop); and (3) maps by Poag (1991). The polygons that define a horizon are identical to those that define the overlying unit.

For the horizons and units deeper than 105 (mid-Cretacous unconformity), stippling has been added along the Carolina slope and Blake Escarpment to show regions where the data contain artifacts because of the gridding methodology, or are otherwise unreliable because of imaging difficulties associated with the carbonate paleo- shelf edge and steep slopes.

Figure 11: Zero-tension gridding of bathymetry using sea floor depths constrained only at the locations of the multichannel seismic reflection data. Artifacts produced by undersampling include scalloping of the contours (Blake Escarpment), incorrect (broader) shape of the Blake Spur, a more rounded appearance of the Blake Ridge, and incorrect shape of the sea floor north of the Bahamas. This figure can be compared with the bathymetry in Figure 3 or the gridded -contoured sea floor in travel time in Appendix IV. 


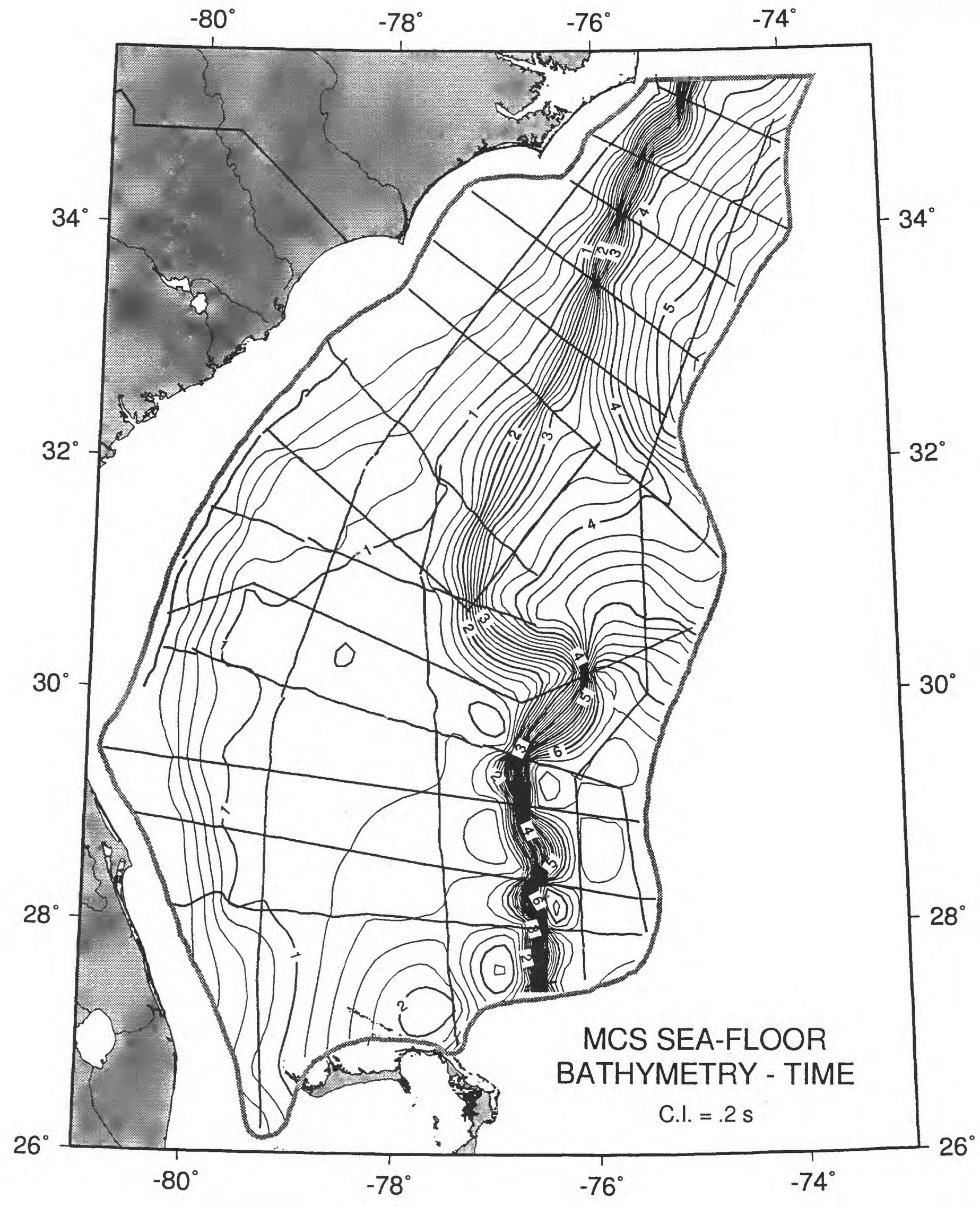


Figure 12: Example of maximum-tension gridding of bathymetry across the Blake Escarpment and Carolina continental margin using sea-floor depths constrained only at the locations of the multichannel seismic reflection profiles. In general, the artifacts (scalloping of the contours) is more extreme than the minimum-tension gridding illustrated in Figure 10. 


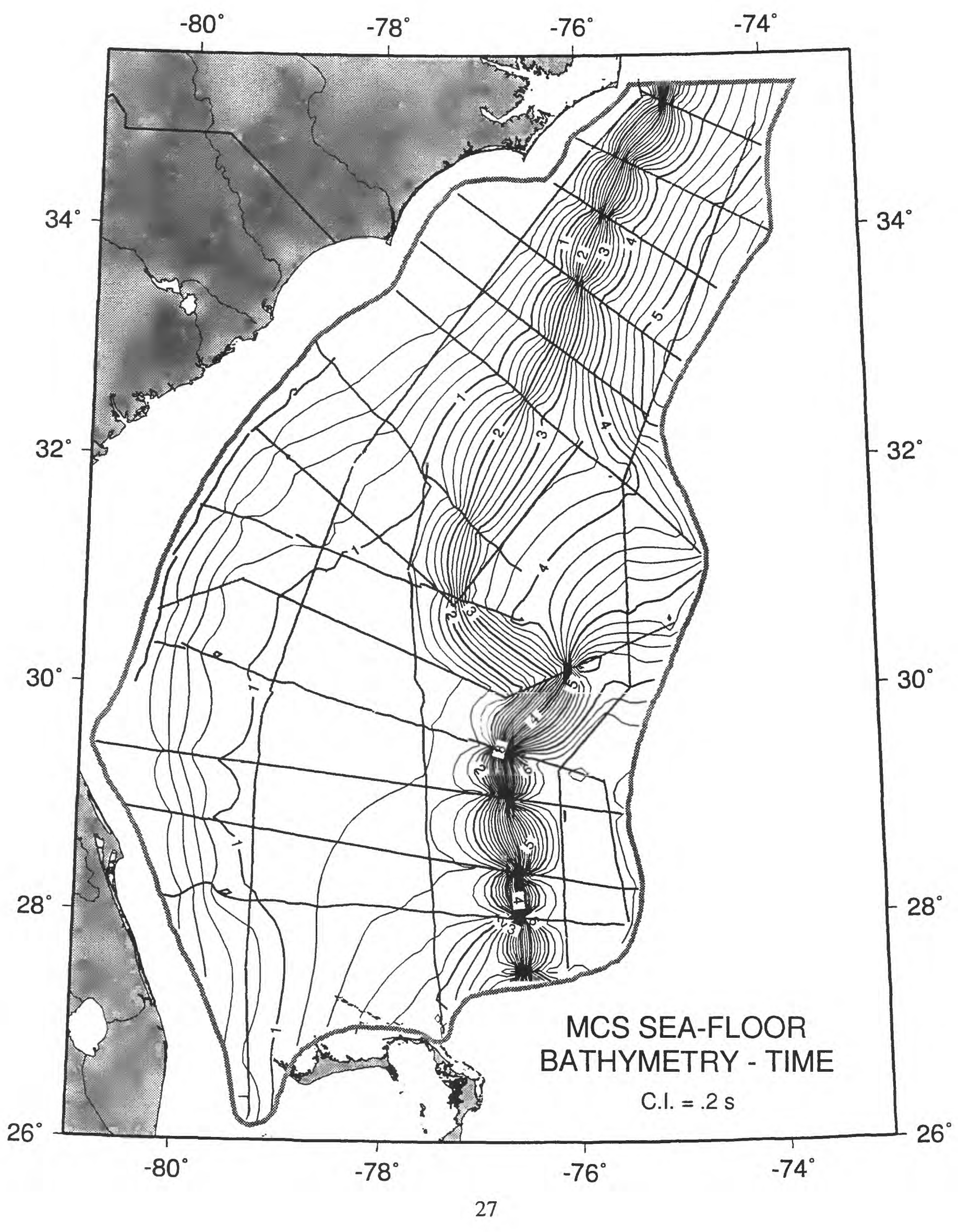


Figure 13: Map showing the distribution of salt diapirs along the Carolina trough (after Dillon et al., 1983). 


\section{Location of Salt Diapirs}

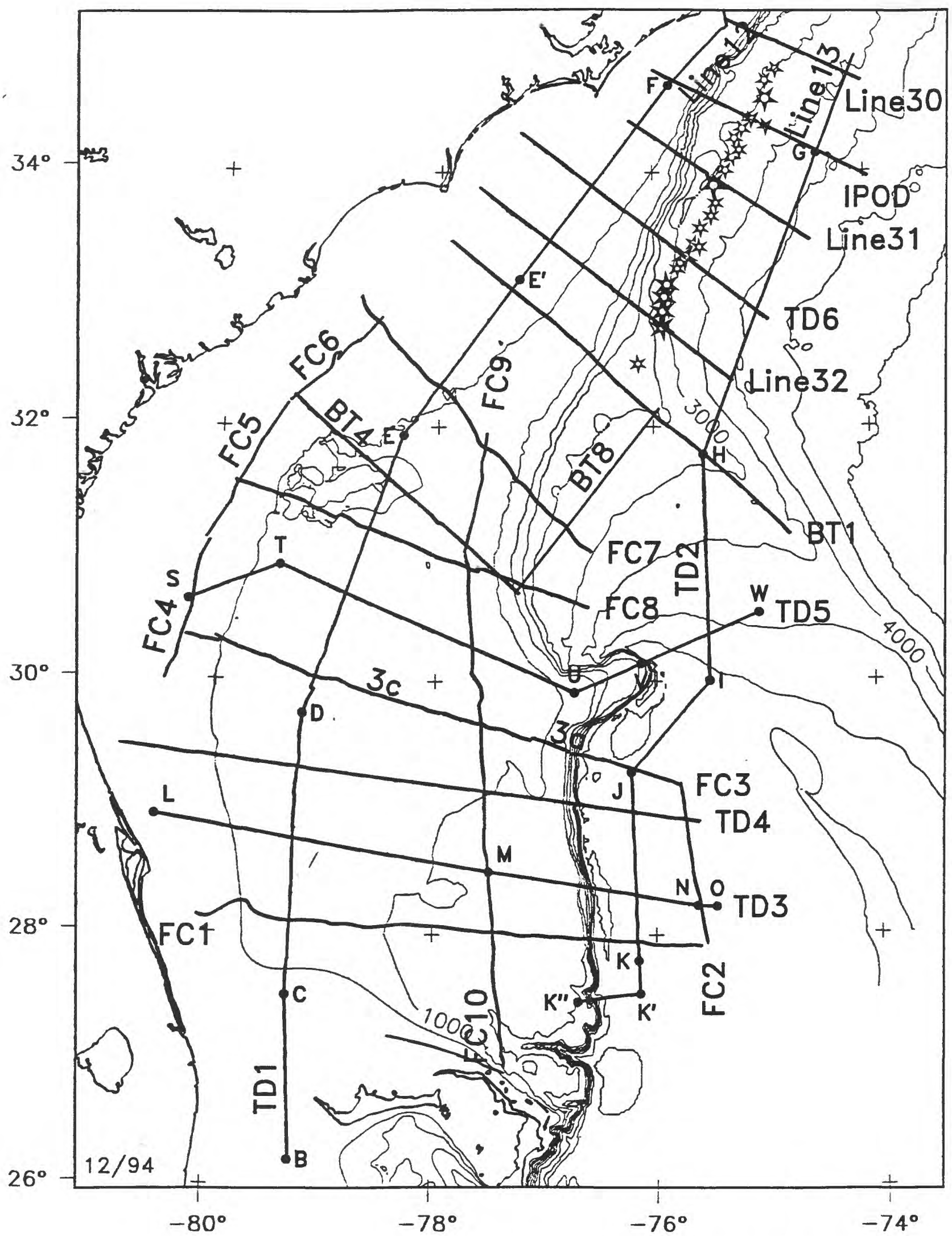

$\Varangle$ Salt Diapir

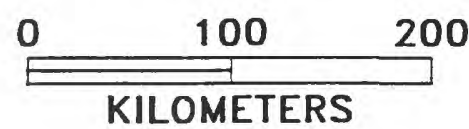


Figure 14: Map showing the locations of grid nodes within the study area. 


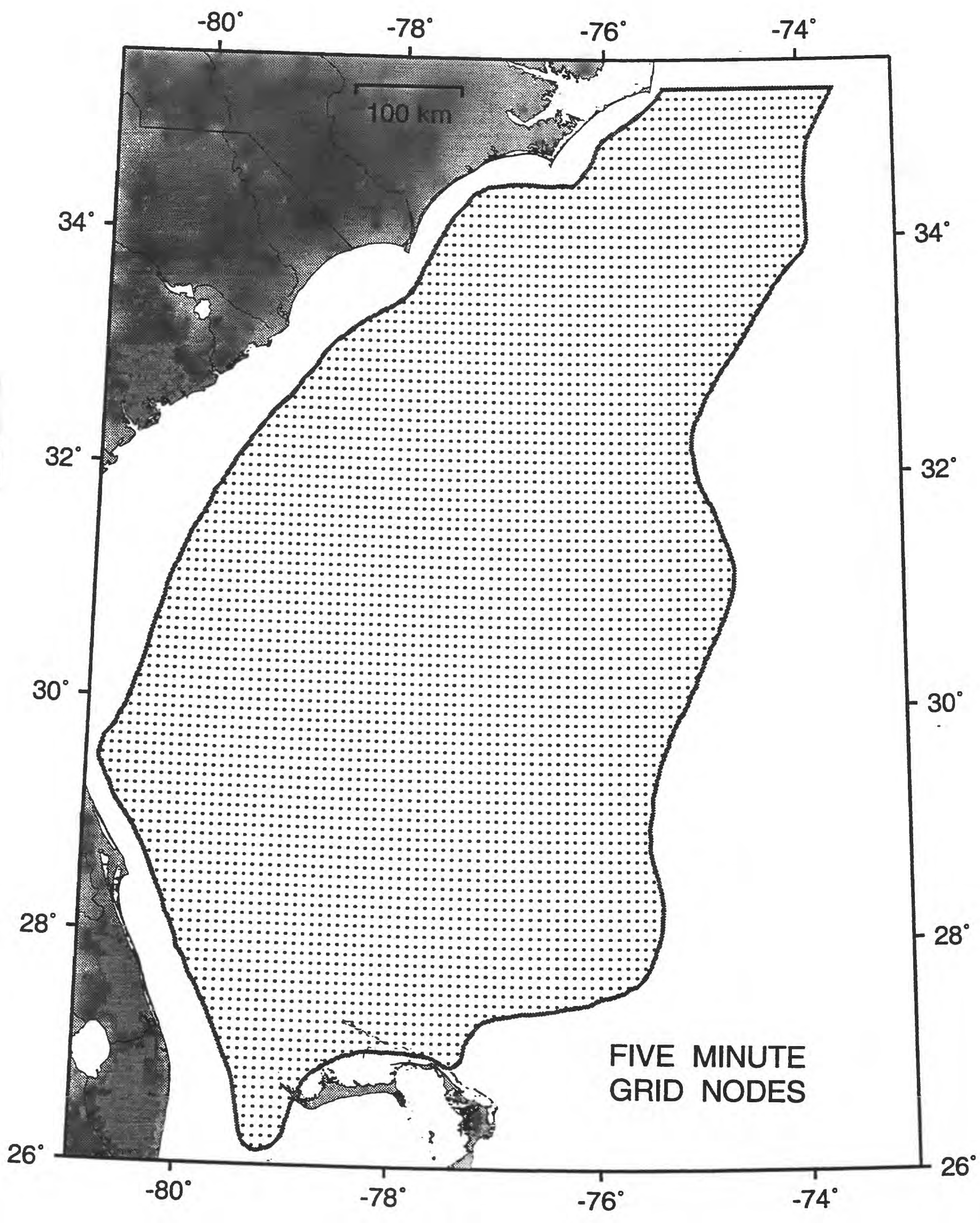


Table 5A: Statistics about Isochrons for each Unit

\begin{tabular}{|c|c|c|c|c|c|c||}
\hline Unit & $\begin{array}{c}\text { Minimum } \\
(\mathrm{sec} .)^{1}\end{array}$ & $\begin{array}{c}\text { Maximum } \\
(\mathrm{sec} .)^{1}\end{array}$ & $\begin{array}{c}\text { Mean } \\
(\mathrm{sec} .)^{1,2}\end{array}$ & $\begin{array}{c}\text { Std.Dev. } \\
(\mathrm{sec} .)^{3}\end{array}$ & $\begin{array}{c}\text { Total } \\
\text { Points }^{4}\end{array}$ & $\begin{array}{c}\text { Nonzero } \\
\text { Points }\end{array}$ \\
\hline \hline 1 & 0.02 & 6.617 & 2.273 & 2.167 & 110798 & $8092^{5}$ \\
\hline 20 & 0 & 0.715 & 0.131 & 0.102 & 25261 & 4099 \\
\hline 30 & 0 & 3.804 & 0.297 & 0.280 & 1732 & 1539 \\
\hline 40 & 0 & 1.491 & 0.297 & 0.331 & 12974 & 4390 \\
\hline 45 & 0 & 2.090 & 0.575 & 0.437 & 3900 & 3228 \\
\hline 50 & 0 & 0.740 & 0.335 & 0.152 & 4984 & 2535 \\
\hline 60 & 0 & 0.734 & 0.189 & 0.116 & 17389 & 5214 \\
\hline 70 & 0 & 1.032 & 0.204 & 0.122 & 17493 & 5601 \\
\hline 80 & 0 & 0.852 & 0.181 & 0.126 & 8197 & 6553 \\
\hline 90 & 0 & 0.728 & 0.216 & 0.119 & 10444 & 6026 \\
\hline 105 & 0 & 0.85 & 0.209 & 0.098 & 11216 & 6771 \\
\hline 110 & 0 & 0.401 & 0.101 & 0.049 & 8875 & 3740 \\
\hline 120 & 0 & 1.000 & 0.406 & 0.195 & 8618 & 7841 \\
\hline 140 & 0 & 1.484 & 0.500 & 0.268 & 11255 & 7760 \\
\hline 150 & 0 & 1.380 & 0.310 & 0.161 & 10868 & 6830 \\
\hline 170 & 0 & 1.140 & 0.578 & 0.296 & 14185 & 5494 \\
\hline 180 & 0 & 1.937 & 0.690 & 0.337 & 13474 & 4725 \\
\hline 190 & 0 & 1.913 & 0.263 & 0.226 & 3957 & 426 \\
\hline \hline
\end{tabular}

1 Minimum, Maximum, and Mean refer to the two-way travel time through the unit.

2 Mean estimated using nonzero values only.

3 Standard Deviation estimated using nonzero values only.

4 Total points includes zero values interpolated along polygon edges.

${ }^{5}$ For Horizon 1 (bathymetry) only, this value is the number of data points along multichannel seismic profiles. The larger value given in the column for Total Points is the actual number of points used in generating grids of the water layer, as described in the text. 
Table 5A: Statistics about Interval Velocity for each Unit

\begin{tabular}{||c|c|c|c|c|c||}
\hline Unit & $\begin{array}{c}\text { Minimum } \\
(\mathrm{m} / \mathrm{s})\end{array}$ & $\begin{array}{c}\text { Maximum } \\
(\mathrm{m} / \mathrm{s})\end{array}$ & $\begin{array}{c}\text { Mean } \\
(\mathrm{m} / \mathrm{s})\end{array}$ & $\begin{array}{c}\text { Std. Dev. } \\
(\mathrm{m} / \mathrm{s})\end{array}$ & $\begin{array}{c}\text { Total } \\
\text { Points }\end{array}$ \\
\hline 1 & 1492 & 1508 & 1500 & 1 & 8092 \\
\hline 20 & 1524 & 2079 & 1702 & 141 & 4103 \\
\hline 30 & 1327 & 1835 & 1723 & 68 & 1621 \\
\hline 40 & 1583 & 2432 & 1905 & 216 & 4395 \\
\hline 45 & 1680 & 2358 & 1970 & 150 & 3235 \\
\hline 50 & 1797 & 2633 & 2112 & 207 & 2540 \\
\hline 60 & 1861 & 2639 & 2403 & 141 & 5224 \\
\hline 70 & 2096 & 2917 & 2641 & 153 & 5613 \\
\hline 80 & 2404 & 3138 & 2854 & 167 & 6557 \\
\hline 90 & 2466 & 3412 & 3013 & 254 & 6032 \\
\hline 105 & 2766 & 3893 & 3420 & 343 & 6773 \\
\hline 110 & 2961 & 4568 & 4170 & 473 & 3745 \\
\hline 120 & 3036 & 5134 & 4125 & 768 & 7847 \\
\hline 140 & 3426 & 5585 & 4509 & 791 & 7765 \\
\hline 150 & 3606 & 5829 & 4827 & 794 & 6840 \\
\hline 170 & 3795 & 6120 & 5277 & 753 & 5505 \\
\hline 180 & 3957 & 6392 & 5654 & 708 & 4734 \\
\hline 190 & 4695 & 6604 & 5480 & 617 & 427 \\
\hline
\end{tabular}

\section{Methodology}

The major limitation described in the section on Spatial Aliasing and Limitations was the undersampling of information across large bathymetric discontinuities such as the Blake Spur and Blake Escarpment. Rather than gridding structure maps directly on each horizon, we chose a strategy of summing grids of layer isochrons and thicknesses to derive structure maps (Figure 15). This approach minimized the magnitude of the discontinuities during gridding because the thickness changes across any individual unit were generally much less than the depth changes along the horizons bounding those units.

A consequence of this approach is that each unit has two basic observational data types: 
isochron (travel time through the unit) and interval velocity. Even though stacking velocities are taken directly from the multichannel seismic data, stacking velocities have no physical significance other than in processing the seismic records (Cordier, 1985). Hence, using velocity in a derivative form - as interval velocities - was the preferred choice for gridding. Summing the isochron grids yields structure maps along horizons in travel time. Thickness maps from each unit were produced by combining the isochron and interval velocity grids (thickness $=$ one-half isochron times interval velocity). Summing the thickness grids yields structure maps along horizons in depth.

The starting isochron, for the water layer, was constructed from digital bathymetry from four sources: (a) contours digitized from 18 NOS sheets at a scale of 1:250,000 that were utilized in EEZ-scan '87 (1991); (b) additional short segments of inner shelf contours digitized from the regional NOS map at 1:1,000,000 (NOS, 1986); (c) digital bathymetric data from the Blake Spur and northern Blake Escarpment compiled by Gilbert and Dillon (1981); and (d) contours of the Bahamas digitized from the regional NOS chart at a scale of 1:1,000,000 (NOS, 1986). The digital contours and data points were combined into one large data file that was gridded at the 5 ' interval for the study area. This bathymetric grid was converted to two-way travel time assuming a velocity of sound in water of $1500 \mathrm{~m} / \mathrm{s}$. Note that the grid map of bathymetry presents the special case where the structure maps and isochron/thickness maps are identical.

After edits to the isochron data (described below) and generation of the isochron grids, all other grids were automatically calculated. In actuality, all grids for a particular horizon were completed before proceeding with the next deeper horizon in order to ensure that no additional edits were warranted, as shown in the flow chart diagram of processing (Figure 15). The final step in completing the grids was to set values to zero or null in regions where the respective unit or horizon did not exist (i.e., within regions defined by the polygons for each horizon).

\section{Edits}

One of the underlying goals of this project was to minimize tedious editing of either the data or the grids, in order to avoid time consuming and inefficient steps. Many artifacts in the gridding may not necessarily indicate "wrong" results that need to be edited, but only represent the "best guess" of the assumptions behind the particular gridding technique. Therefore, we developed a set of edits that allowed us to minimize these artifacts while simultaneously showing the raw data in its most geologically realistic form. The final grids developed for this project contain the following edits performed to improve the quality of the maps:

(1) Zero values: All of the polygon points defining the subcrop limit of each unit were added to the original input isochron data as zero values before gridding to help constrain the shape of the zero contour.

Figure 15: Flow chart showing the steps used in constructing the grids from the digitized profile data. 


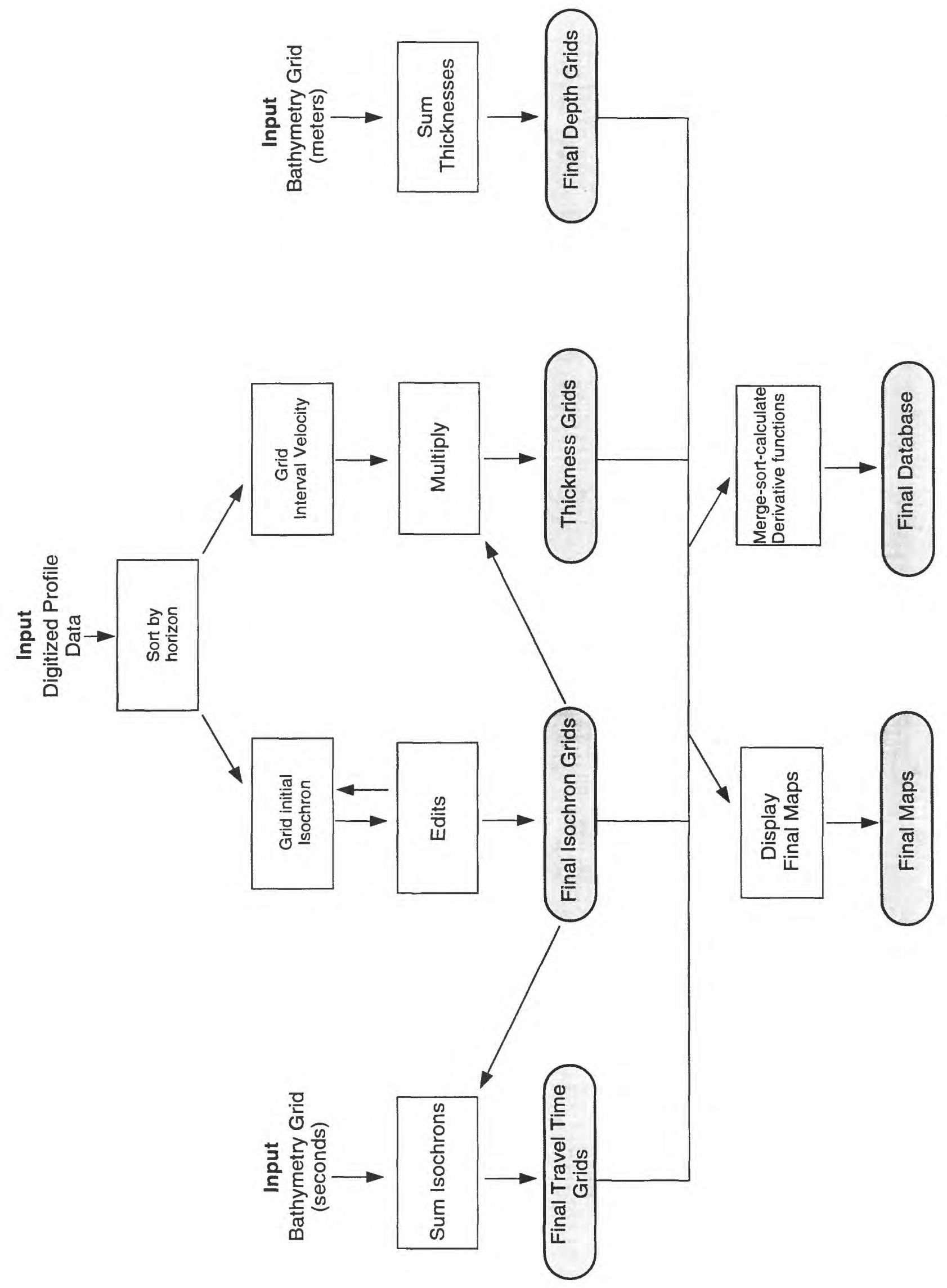


(2) Isochron contour edits: Two conditions arose that required editing the isochron contours: (a) Unwarranted maximum and miminum peaks in areas of no data control that occurred because of the gridding assumption of zero tension; and (b) contour lines that crossed into or across the zones of pinchout because the zone of pinchout was narrower than or equivalent to the grid dimension $(7-9 \mathrm{~km})$. Narrow zones of pinchout were common at sites of erosion near the paleo-shelf edge in the Carolina trough and across the Blake Escarpment. For these situations (most units deeper than 40), the grids were edited to generate contours and contour shapes that either removed/minimized the unnecessary peaks or illustrated the existence of zero values at the pinchout. These edits generally affected less than $10 \%$ of the map area and consisted of digitizing new contour shapes and values, then regridding and recontouring that portion of the map.

(3) Final zeroing and nulling: Final grids and maps were generated by setting all isochron and thickness grid values to zero in regions of zero thickness, by setting all interval velocity and lithology grid values to null in regions of zero thickness, and by setting the structure map grid values to null where the particular horizon does not exist.

In this way, the only substantive edits to the grids were performed during gridding of the isochron values. All other grids could be automatically computed as soon as the isochron grids were generated.

\section{Unedited Artifacts}

Some of the structure maps on horizons older than mid-Cretaceous show exaggerated and unrealistic short-wavelength undulations in the contours near the Carolina slope and Blake Escarpment. These anomalies are spatially associated with erosion at the paleo-shelf edge and are most obvious in regions of no data (between lines). These anomalies are the result of the gridding strategy of summing grids in areas where overlapping pinchouts occur. These zones are shown with stippling on the maps of horizons 105 (mid-Cretaceous) to 190 (Middle Jurassic). Even though the data values at these grid points are poor, they have been left in the data base because (a) they illustrate limitations of the gridding strategy; and (b) smoothing would have required iterative edits on the structure and isochron maps to make an internally consistent data set. Adjusting the isochrons at this step would have been a tedious job that violated our goal of streamlining the gridding so that the isochron maps were the simplest representation of the original observational data.

\section{MAPS}

All of the grids associated with development of the database are shown in map form in Appendices 1 - 6 for each numbered horizon. All maps are shown at the same scale and each set of maps uses the same contour interval and display parameters.

\section{Isochron Maps}

The isochron maps (Appendix 1) are illustrated at a contour interval of $.1 \mathrm{~s}$. This interval represents thicknesses of 75-100 m per contour for the shallower units and increases to about $250-300 \mathrm{~m}$ per contour for the deeper units. Total two-way travel times through the Cenozoic to middle Cretaceous units (units 20-110) tend to be less than $.3 \mathrm{~s}$, whereas travel times through the Lower Cretaceous and Jurassic units (units 120-190) are larger (.6 s or 
greater). Distribution patterns of the units show that very little deposition has occurred on the continental shelf and Blake Plateau since Miocene times, in contrast to widespread and thick occurences of many of the Cretaceous and Jurassic units across the entire margin.

\section{Interval Velocity Maps}

The interval velocity grids (Appendix 2) are shown with a contour interval of $50 \mathrm{~m} / \mathrm{s}$, which emphasizes the trends in velocity anomalies, even though many of the velocity data may not be accurate to better than $50 \mathrm{~m} / \mathrm{s}$ (Hutchinson et al., 1995). No polygon boundaries other than the master polygon are shown in the velocity maps so that velocity trends are not interrupted with the subcrop bounding lines. Because velocity contours originally may have been be continuous across regions of erosion, unlike thickness contours, this display provides the most logical display of velocity trends.

Velocities show a range of values for each unit. This range can be small (1800-1900 $\mathrm{m} / \mathrm{s}$ for unit 40 ) or large $(4500-6300$ for unit 180$)$. Within any unit, velocities tend to be higher in the Blake Plateau than in the Carolina trough, which reflects the higher carbonate contents found within the Plateau; and they also tend to be higher on the shelf than in the abyssal plain for any unit, which probably reflects the greater depth of burial of the shelf deposits compared to their deep-water equivalents. These observations lead to the general pattern of higher velocities at similar depths beneath the Blake Plateau than the Carolina trough and beneath the shelf than further offshore. Most of the deeper units (units 120-180) show a velocity maximum elongated down the axis of the Carolina trough, which indicates the approximate position of the reef complex that developed along the Jurassic-Cretaceous paleoshelf edge (Poag, 1991).

\section{Thickness Maps}

The thickness grids (Appendix 3) for each unit were constructed by combining the isochron and interval velocity grids (with a multiplier of .5 to account for two-way travel time). The contour interval on these maps $(50 \mathrm{~m})$ is used to highlight trends in depositional and erosional patterns (particularly of the thinner units), although the uncertainty in unit thickness probably exceeds $50 \mathrm{~m}$ for the deeper units (Hutchinson et al., 1995).

The magnitude and locus of thickest deposition varies considerably through time: In the Middle Jurassic (unit 170), deposits in excess of $3 \mathrm{~km}$ were deposited in the central Blake Plateau, whereas the Upper Cretaceous (unit 90) contains maximum thicknesses of about 750 $\mathrm{m}$ beneath the Carolina slope and along the Florida Hatteras slope near the inner Blake Plateau. By the end of Jurassic time, thicknesses change from greater than 1-3 km to generally less than $1 \mathrm{~km}$ thick. The notable exception is when more than $2 \mathrm{~km}$ of deposits accumulated on the Blake Ridge in mid-Miocene time (unit 45). The reduced thicknesses of deposits in the Cenozoic and their distribution in deep water reflects the combined effects of greater current activity and changing sea-level conditions that have caused sediments to bypass the shelf for deeper water (e.g., Dillon and Popenoe, 1988).

\section{Structure Maps - Time}

The structure maps in travel time (Appendix 4) were generated by summing the isochron grids for each successive unit, starting with the bathymetry isochron grid. These structure maps represent total travel times from the sea surface to a horizon. The contour 
interval of $.2 \mathrm{~s}$ is consistent with the interval used by Klitgord et al. (1994) for the area north of Cape Hatteras.

These maps show the general configuration of increasing travel times to successively deeper horizons. Because of the dominating effect of the low-velocity, thick water column, these maps tend to be dominated by the shape of the water surface and travel times to horizons beneath the abyssal plain always exceed those beneath the shelf. For this reason, the structure maps in depth are better for investigating areal variations in the shape and geometry of the horizons. The maps for horizons 105-190 show the regions where gridding across discontinuities in thickness (at the paleo-shelf edge and the Blake Escarpment) are introducing short-wavelength anomalies in areas of no data control (stippled areas).

\section{Structure Maps - Depth}

The structure maps in depth (Appendix 5) are identical to the structure maps in time except they are constructed by summing the thickness grids. They show the depth of a horizon below sea level. The contour interval used for these maps is $200 \mathrm{~m}$. Somewhat worse contouring artifacts exist in these maps than for the equivalent structure maps in time because inaccuracies in both travel time (isochron grids) and velocity (interval velocity grids) are compounded. Stippling on the maps of horizons 105 to 190 flags the regions of contouring artifacts.

The depth maps show several prominent features and trends. The base of the oldest deposits is about $3 \mathrm{~km}$ deeper in the Blake Plateau (at about $13.5 \mathrm{~km}$ ) than in the Carolina trough (at about $10.5 \mathrm{~km}$ ). In contrast, the maximum depth of Cretaceous deposits is several kilometers shallower beneath the Blake Plateau $(4 \mathrm{~km})$ than beneath the Carolina trough $(7$ $\mathrm{km}$ ). The Jurassic paleo-shelf edge served to trap huge thicknesses of sediment into Early Cretaceous time. The Cretacous horizons show the effects of widespread erosion; Cretaceous horizons are best preserved beneath the shelf and Blake Plateau and are often non-existent beneath the rise and abyssal plain. The maximum depths to the top of Cretaceous deposits are shallower beneath the Blake Plateau $(1.5 \mathrm{~km})$ than beneath the Carolina trough $(5-6 \mathrm{~km})$. Cenozoic time has been characterized by deposition primarily in deep water. Very few Cenozoic horizons are mappable on the Blake Plateau. Through time, the shelf edge has migrated landward in the northern Carolina trough.

These patterns in the depths to horizons are the result of shifting sediment supplies, differences in sea level, variations in subsidence history (related to contrasting rift histories and basement types), changes in climate, and changes in current regimes (Dillon and Popenoe, 1988).

\section{Lithology Maps}

The final set of grids, shown as lithology maps in Appendix 6, show simplified lithologic information for each unit. These maps were compiled from limited drill and sample information available (Table 3) and seismic facies analysis from the interpretation of the multichannel seismic profiles (e.g., Poag and Valentine, 1988; Dillon and Popenoe, 1988; Poag, 1985, 1991). Seismic facies analysis can be highly subjective (e.g., Vail et al., 1977), therefore the maps used in this project have been purposely kept simple. Only six lithologies are 
identified (Table 6). No attempt was made to show gradational changes between lithologies, although such gradations are likely to occur.

These maps show how Jurassic, Cretaceous, and early Cenozoic deposits (units 190 70) are dominated by carbonate deposition (limestone, chalk, and dolomite) with variable amounts of clastic input, whereas Cenozoic deposits (units 20 - 70) are progressively more clastic (shale and silt/sand). The carbonate paleo-shelf/reef trend mapped by Poag (1991) can be seen in the maps of Jurassic units in the Carolina trough (units $120-180$ ), but is not identifiable in the Cretaceous maps (units 80 - 110). Salt is identified only in the deepest unit (190) in the northern Carolina trough.

A geographic pattern also emerges in that the Blake Plateau is more carbonate-rich than the Carolina trough, which is more transitional with a clastic regime (e.g., units 105 and 80). Coarser terrigenous lithologies (such as silt/sand) tend to be located along the shelf and inner shelf. Finer terrigenous deposits (shale) tend to be in deeper water seaward of the sand/silt deposits. Many of the Cenozoic silt/sand deposits are delta/fan complexes that developed during high-stands of sea level when the Suwanee current crossed northern Florida and the Gulf Stream was intensifying (e.g., Popenoe, 1985, 1987; Dillon and Popenoe, 1988).

Table 6: General Lithologic Types

\begin{tabular}{|c|c|}
\hline ROCK TYPE & NUMERICAL CODE \\
\hline \hline Silt/Sand & 02 \\
\hline Clay/Shale & 04 \\
\hline Chalk & 06 \\
\hline Limestone & 08 \\
\hline Dolomite & 10 \\
\hline Halite/Anhydrite & 12 \\
\hline
\end{tabular}

\section{CONSTRUCTION OF GEOACOUSTIC DATABASE}

\section{Geoacoustic Parameters}

The suite of acoustic parameters developed for the database and the formulas for calculating them are given in Table 7. The calculations estimated directly from the velocity and thickness information of the grids were density (Hamilton, 1978) and shear-wave velocity (Hamilton, 1979).

In order to estimate compressional- and shear-wave attenuation, surface sediment grain-size information must be known. The map of surface sediment grain size (Figure 10) shows the dense sampling on the continental shelf and Blake Plateau, and the paucity of data 
from the abyssal plain. Surface compressional-wave attenuation (Figure 16) was estimated from surface sediment grain size information using the Biot-Stoll model (Table 8), which is applicable only for frequencies below $1 \mathrm{kHz}$ (Stoll, 1985). Because of the lack of sediment grain-size information on the abyssal plain, and the assumption that grain size changes very little along the abyssal plain south of Hatteras, a value of $0.04 \mathrm{~dB} / \mathrm{m}$ was assigned to the entire deep-water region. Surface attenuation was then used as one of the inputs to estimating the compressional-wave attenuation of the deeper layers (Mitchell and Gocke, 1980; Stoll, 1985). Shear-wave attenuation was estimated directly from the compressional-wave attenuation using the relationships developed by Hamilton (1976a, 1976b) and Castagna et al. (1985).

\section{Methodology}

The database was compiled by merging the digital grids (isochron, interval velocity, thickness, structure maps in time, structure maps in depth, lithology, and surface grain-size) into one large file, sorting each grid point by latitude and longitude, performing the derivative calculations using the formulas cited in Table 7, and outputting the results into two formats (described below). All numeric calculations were performed using programs and scripts developed by USGS using MATLAB (registered trademark of the Math Works, Inc.).

\section{Formats}

The data base is sorted first by latitude, then longitude, so that each row of grid points is listed from west to east, progressing from south to north. The data base is stored in two formats:

(a) By grid node (Table 9), which lists all the horizon information relative to a particular grid node. Latitude and longitude are given in the first two lines followed by a line containing thirteen fields associated with each horizon number defined at that node point (starting at the sea floor). Blank lines separate each grid node from the next, and headers explaining each field are printed for each grid node.

(b) By horizon number (Table 10), which lists 15 fields of data for each horizon. This format is ordered identically to the grid-node format, except that latitude and longitude are given as the first two fields of each line, as opposed to being the first two lines of the data. This format is compressed relative to the grid node format because latitude/longitude are not stored on separate lines and because headers and blank lines are not included at each new grid node. A single explanatory header exists in the first line of the file.

Figure 16: Map of surface compressional-wave attenuation. This map was constructed using the grain-size information (Figure 10) converted to attenuation using the relationships described in Table 8. 


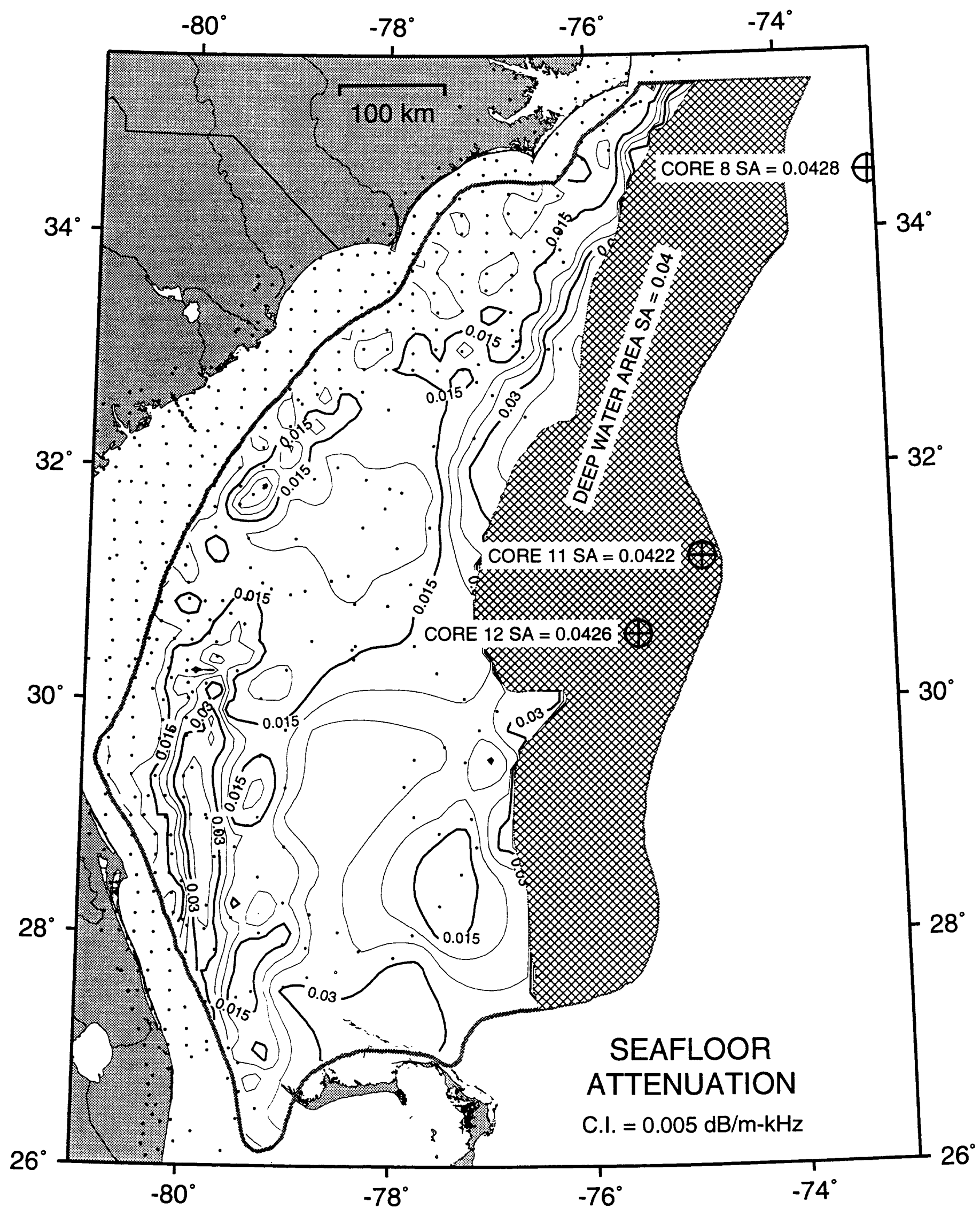


Table 8: Surficial Sediment Type and Surface Attenuation

\begin{tabular}{||l|c|c|c||}
\hline Sediment Type & $\begin{array}{c}\text { Phi } \\
\text { Class }\end{array}$ & Grain Size (mm) & $\begin{array}{c}\text { Surface } \\
\text { Attenuation }\end{array}$ \\
\hline \hline Coarse sand & $<1$ & $>0.5$ & 0.005 \\
\hline Medium sand & $<2$ & $0.25-0.5$ & 0.010 \\
\hline Fine sand & $<3$ & $0.125-0.25$ & 0.015 \\
\hline Sandy silt & $<4$ & $0.0625-0.125$ & 0.020 \\
\hline Silty sand & $<5$ & $0.0312-0.0625$ & 0.025 \\
\hline Silt & $<6$ & $0.0156-0.0312$ & 0.030 \\
\hline Silty clay & $<7$ & $0.0078-0.0156$ & 0.035 \\
\hline Clayey silt & $<8$ & $0.0039-0.0078$ & 0.040 \\
\hline Clay & $<9$ & $0.00195-0.0039$ & 0.045 \\
\hline
\end{tabular}

${ }^{1}$ Sediment types in order of decreasing grain size.

2 Attenuation $\left(\mathrm{k}_{0}\right)$ values are compressional-wave surface attenuation in $\mathrm{dB} / \mathrm{m}-\mathrm{kHz}$ where $\alpha=\mathrm{k}_{0} \mathrm{f}^{\mathrm{m}}$ based on the Biot-Stoll model and applicable only below $1 \mathrm{kHz}$ (Stoll, 1985).

Table 9: Database Format by Grid Node

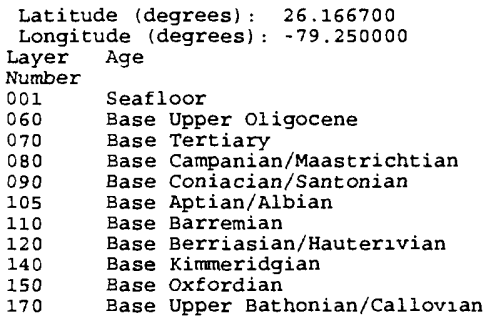

$\begin{array}{ccc}\text { Travel } & \text { Depth } \\ \text { Time } & (\mathrm{m}) & \begin{array}{c}\text { Thickness } \\ (\mathrm{m})\end{array} \\ 0.579 & 434 & 434 \\ 1.032 & 985 & 551 \\ 1.247 & 1275 & 290 \\ 1.576 & 1749 & 473 \\ 1.668 & 1899 & 150 \\ 1.762 & 2080 & 180 \\ 1.802 & 2170 & 90 \\ 2.156 & 3081 & 911 \\ 2.845 & 4991 & 1909 \\ 2.892 & 5125 & 133 \\ 2.909 & 5179 & 53 \\ & & \end{array}$

$\begin{array}{ccc}\text { Density } & \text { RMS } & \text { Velocity } \\ (\mathrm{gm} / \mathrm{cm} \star 3) & \text { Velocity } & \text { P-Wave } \\ 1.000 & 1500 & 1500 \\ 2.253 & 1964 & 2432 \\ 2.343 & 2109 & 2701 \\ 2.396 & 2291 & 2878 \\ 2.501 & 2357 & 3297 \\ 2.594 & 2459 & 3834 \\ 2.653 & 2524 & 4551 \\ 2.747 & 3109 & 5141 \\ 2.810 & 3843 & 5543 \\ 2.843 & 3881 & 5751 \\ 2.881 & 3898 & 5989\end{array}$

$\begin{array}{cc}\text { Velocity } & \text { Surf-Atten } \\ \text { S-Wave } & (\mathrm{db} / \mathrm{m}-\mathrm{kHz}) \\ 0 & 0.019 \\ 935 & : \\ 1145 & : \\ 1283 & : \\ 1610 & : \\ 2029 & : \\ 2588 & : \\ 3048 & : \\ 3361 & : \\ 3524 & : \\ 3709 & :\end{array}$

P-Atten
$(\mathrm{db} / \mathrm{m}-\mathrm{kHz})$
0.000
0.059
0.074
0.010
0.010
0.010
0.010
0.010
0.010
0.010
0.010

S-Atten
(db/m-kHz)
0.000
0.067
0.059
0.007
0.005
0.004
0.003
0.002
0.002
0.002
0.002

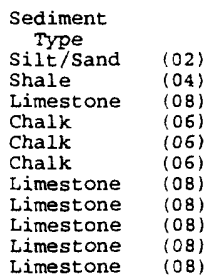

Table 10: Database Format by Horizon Number

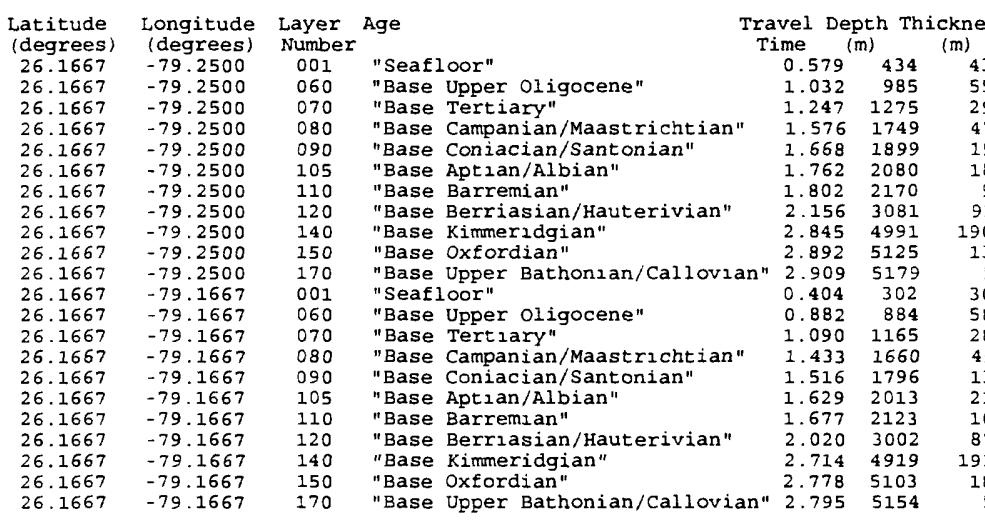

\begin{tabular}{|c|c|c|c|c|c|}
\hline $\begin{array}{l}\text { ravel De } \\
\text { Time }\end{array}$ & n) & $\begin{array}{l}\text { ckness } \\
\text { (m) }\end{array}$ & $\begin{array}{l}\text { Density } \\
\left(\mathrm{gm} / \mathrm{cm}^{\star} \star 3\right)\end{array}$ & $\begin{array}{l}\text { RMS V } \\
\text { Velocity }\end{array}$ & $\begin{array}{l}\text { Jelocity } \\
\text { y p-Wave }\end{array}$ \\
\hline 0.579 & 434 & 434 & 1.000 & 1500 & 1500 \\
\hline 1.032 & 985 & 551 & 2.253 & 1964 & 2432 \\
\hline 1.247 & 1275 & 290 & 2.343 & 2109 & 2701 \\
\hline 1.576 & 1749 & 473 & 2.396 & 2291 & 2878 \\
\hline 1.668 & 1899 & 150 & 2.501 & 2357 & 3297 \\
\hline 1.762 & 2080 & 180 & 2.594 & 2459 & 3834 \\
\hline 1.802 & 2170 & 90 & 2.653 & 2524 & 4551 \\
\hline 2.156 & 3081 & 911 & 2.747 & 3109 & 5141 \\
\hline 2.845 & 4991 & 1909 & 2.810 & 3843 & 5543 \\
\hline 2.892 & 5125 & 133 & 2.843 & 3881 & 5751 \\
\hline 2.909 & 5179 & 53 & 2.881 & 3898 & 5989 \\
\hline 0.404 & 302 & 302 & 1.000 & 1500 & 1500 \\
\hline 0.882 & 884 & 581 & 2.254 & 2059 & 2434 \\
\hline 1.090 & 1165 & 280 & 2.343 & 2196 & 2701 \\
\hline 1.433 & 1660 & 495 & 2.398 & 2379 & 2885 \\
\hline 1.516 & 1796 & 135 & 2.497 & 2437 & 3283 \\
\hline 1.629 & 2013 & 217 & 2.592 & 2558 & 3821 \\
\hline 1.677 & 2123 & 109 & 2.652 & 2636 & 4544 \\
\hline 2.020 & 3002 & 879 & 2.744 & 3199 & 5128 \\
\hline 2.714 & 4919 & 1917 & 2.808 & 3929 & 5531 \\
\hline 2.778 & 5103 & 183 & 2.841 & 3979 & 5739 \\
\hline 2.795 & 5154 & 51 & 2.880 & 3995 & 5982 \\
\hline
\end{tabular}

locity Sur
0
935
1145
1283
1610
2029
2588
3048
3361
3524
3709
0
936
1145
1288
1599
2018
2582
3038
3352
3514
3704

-Atten
P-Att-kHz)
$(\mathrm{db} / \mathrm{m}$
0.019
0.019
0.019
0.019
0.019
0.019
0.019
0.019
0.019
0.019
0.019
0.020
0.020
0.020
0.020
0.020
0.020
0.020
0.020
0.020
0.020
0.020

$\begin{array}{ccc}\text { Sen } & \text { S-Atten Sedimen } \\ \text { m-kHz) } & (\mathrm{db} / \mathrm{m}-\mathrm{kHz}) & \text { Typ } \\ 0.000 & 0.000 & 0 \\ 0.059 & 0.067 & 04 \\ 0.074 & 0.059 & 0 \\ 0.010 & 0.007 & 0 \\ 0.010 & 0.005 & 0 \\ 0.010 & 0.004 & 0 \\ 0.010 & 0.003 & 0 \\ 0.010 & 0.002 & 0 \\ 0.010 & 0.002 & 0 \\ 0.010 & 0.002 & 0 \\ 0.010 & 0.002 & 0 \\ 0.000 & 0.000 & 0 \\ 0.052 & 0.059 & 0 \\ 0.012 & 0.010 & 0 \\ 0.010 & 0.007 & 0 \\ 0.010 & 0.005 & 0 \\ 0.010 & 0.004 & 0 \\ 0.010 & 0.003 & 0 \\ 0.010 & 0.002 & 0 \\ 0.010 & 0.002 & 0 \\ 0.010 & 0.002 & 0 \\ 0.010 & 0.002 & 0\end{array}$




\section{DISCUSSION}

This digital compilation of stratigraphic information from south of Cape Hatteras completes the digitization of the major sedimentary basins from the offshore U.S. Atlantic continental margin (Klitgord et al., 1994). Despite artifacts included in the grids, this compilation offers excellent opportunities for undertaking three-dimensional visualization and modelling studies of nearly an entire passive continental margin, particularly if combined with other regional geophysical data, such as gravity, magnetics, and crustal-structure information. These digital data will make it possible to investigate the three-dimensional partitioning between tectonic, depositional, erosional, magmatic, and eustatic processes in the development of the continental margin.

A compilation of this magnitude requires compromises and choices at nearly every step of the analysis. Part of the reason this was such a time consuming project was the manual nature of many of the steps in the process: e.g., digitizing and hand-editing horizons from the profile data (Hutchinson et al., 1995) and digitizing contours and regridding for the gridding portion of the project. Generally these were done with separate software packages that each used separate internal storage formats (e.g., Wright and Hosom, 1977; Smith and Wessel, 1990). The person processing the data had multiple files in multiple formats to track and save at nearly every step. A clear improvement in the process would be automating the profile digitizing process and combining the digitizing and gridding steps in one software package. Unfortunately, such an all-encompassing software package was not available at the start of this project, but these packages are widely available and utilized most frequently by the petroleum industry for exploration purposes. The single biggest recommendation from this project would be to encourage future compilations from other continental margins of the world to purchase and utilize these new-generation software packages.

\section{SUMMARY}

This report describes the gridding of digital stratigraphic and lithologic information and the calculation of derivative acoustic information for the U.S. Atlantic continental margin between Florida and Cape Hatteras. It complements an earlier report describing the profile data on which the gridding is based (Hutchinson et al., 1995). The area to the north, between Cape Hatteras and Georges Bank has been summarized in Klitgord and Schneider (1994) and Klitgord et al. (1994).

(1) Two of the large offshore post-Middle Jurassic sedimentary basins are included in this compilation: the Blake Plateau basin, which is the widest, most equidimensional, and most carbonate-rich of the U.S. Atlantic offshore basins, and the Carolina trough, which is the narrowest, most linear basin and is transitional between carbonate deposition to the south and more clastic, terrigenous regions to the north.

(2) Digital maps for 17 post-Middle Jurassic units (18 horizons) are developed using a grid-node spacing of 5 minutes $(9.23 \times 7.96 \mathrm{~km})$. The units consist of the water column plus 7 Cenozoic, 5 Cretaceous, and 5 Jurassic units. Maps are included for isochron, interval velocity, thickness, lithology, and structure maps in both travel time and depth. 
(3) Spatial aliasing occurs because the sample rate along lines $(250 \mathrm{~m})$ is much greater than the distance between lines $(30-40 \mathrm{~km})$. Because of this undersampling, and the rather large grid interval, features such as large discontinuities (Blake Escarpment), certain non-twodimensional features (Blake Spur), narrow linear features (faults or reefs), and point source features (diapirs) are not always properly imaged in the gridding process.

(4) The strategy adopted to minimize the editing during gridding and also realistically to present the data and geology, was to grid layer thicknesses, then sum grids to estimate depths to horizons. This strategy resulted in short-wavelength anomalies along the axis of the Carolina Slope and Blake Escarpment that are not geologically probable, and these are most noticeable for middle Cretaceous and older horizons.

(5) From the digital stratigraphic, velocity, and thickness information, derivative calculations of density, shear-wave velocity, and compressional- and shear-wave attenuation were made. 


\section{REFERENCES CITED}

Anderson, R.C., and Taylor, D.J., 1979, Geophysical studies, in P.A. Scholle, ed., Geological studies of the COST GE-1 well, United States South Atlantic Outer Continental Shelf area. U.S. Geological Survey Circular 800, p. 93-96.

Behrendt, J.C., Hamilton, R.M., Ackermann, H.D., Henry, V.J., and Bayer, K.C., 1983, Marine multichannel seismic-reflection evidence for Cenozoic faulting and deep crustal structure near Charleston, South Carolina, in Gohn, G.S., ed., Studies related to the Charleston, South Carolina, earthquake of 1886 - tectonics and seismicity: U.S. Geological Survey Professional Paper 1313, p. J-1 - J-29.

Behrendt, J.C., and Yuan, A., 1986, The Helena Banks strike-slip (?) fault and the relation to other Cenozoic faults along reactivated Triassic (?) basin boundary fault zones in the Charleston, S.C., earthquake area -- results from a marine high-resolution multichannel seismic reflection survey: Geological Society of America Bulletin, v. 98, p. 591-601.

Benson, W.E., Sheridan, R.E., et al., 1978, Initial Reports of the Deep Sea Drilling Project, v. 44: Washington (U.S. Government Printing Office), 1005 pp.

Bryan, G.M., 1970, Hydrodynamic model of the Blake Outer Ridge: Journal of Geophysical Research, v. 75 , p. 4530 - 4537.

Bryan, G.M, Markl, R.G., and Sheridan, R.E., 1980, IPOD site surveys in the Blake Bahamas basin: Marine Geology, v. 35, p. 43 - 63.

Bunce, E.T., Emery, K.O., Gerard, R.D., Knott, S.T., Lidz, L., Saito, T., and Schlee, J., 1965, Ocean Drilling on the Continental Margin: Science, v. 150, p. 709-716.

Castagna, J.P., Batzle, M.L., and Eastwood, R.L., 1985, Relationships between compressionalwave and shear-wave velocities in clastic silicate rocks: Geophysics, v. 50, p. 571-581.

Charm, W.B., Nesteroff, W.D., and Valdes, S., 1969, Detailed stratigraphic description of the JOIDES cores on the continental margin off Florida: U.S. Geological Survey Professional Paper 581-D, 13 pp.

Cordier, J.-P., 1985, Velocities in Reflection Seismology; Dordrecht, Holland, D. Reidel Publishing Co., $201 \mathrm{p}$.

Dillon, W.P., Fehlhaber, K., Coleman, D.F., Lee, M.W., and Hutchinson, D.R., 1995, Maps showing gas-hydrate distribution off the East Coast of the United States: U.S. Geological Survey Miscellaneous Field Studies Map MF-2268, 1:1,000,000, 2 sheets.

Dillon, W.P., Lee, M.W., and Coleman, D.F., 1994, Identification of marine hydrates in situ and their distribution off the Atlantic coast of the United States: Annals of the New York Academy of Sciences, v. 715, p. $364-380$. 
Dillon, W.P., and McGinnis, L.D., 1983, Basement structure indicated by seismic-refraction measurements offshore from South Carolina and adjacent areas: U.S. Geological Survey Professional Paper 1313, p. O1 - O7.

Dillon, W.P., Paull, C.K., and Gilbert L.E., 1985, History of the Atlantic Continental Margin off Florida; The Blake Plateau basin, in Poag, C.W., ed., Geologic evolution of the United States Atlantic margin: New York, Van Nostrand Reinhold, p. 189-215.

Dillon, W.P., and Popenoe, P., 1988, The Blake Plateau Basin and Carolina Trough, in Sheridan, R.E., and Grow, J.A., eds., The Atlantic Continental Margin, U.S.: Geological Society of America, The Geology of North America, v. I-2, p. 291 - 328.

Dillon, W.P., Popenoe, P., Grow, J.A., Klitgord, K.D., Swift, B.A., Paull, C.K. and Cashman, K.V., 1983, Growth faulting and salt diapirism, their relationships and control in the Carolina Trough, eastern North America, in Watkins, J.S., and Drake, C.L., eds., Studies in continental margin geology: American Association of Petroleum Geologists Memoir 34, p. 21-46.

Dillon, W.P., Sheridan, R.E., and Fail, J.P., 1976, Structure of the western Blake Bahama Basin as shown by 24 channel CDP profiling: Geology, v. 4, p. 459-462.

Dillon, W.P., Trehu, A.M., Valentine, P.C., and Ball, M.M., 1988, Eroded carbonate platform margin - the Blake Escarpment off Southeastern United States: in Bally, A.W., ed., Atlas of Seismic Stratigraphy: American Association of Petroleum Geologists Studies in Geology \#27, v. 2, p. 140-147.

Dillon, W.P., Valentine, P.C., and Paull, C.K., 1987, The Blake Escarpment -- a product of erosional processes in the deep ocean, in Cooper, R.A., and Shepard, A.N., eds., Science Applications of Current Diving Technology on the U.S. Continental Shelf: NOAA Symposium Series Undersea Research, v. 2, p. 177 - 190 (NOAA Undersea Research Program, Rockville, MD).

Dix, C.H., 1955, Seismic velocities from surface measurements,: Geophysics, v. 20, p. 68-86.

Dowling, J.J., 1968, The East Coast onshore-offshore experiment, II. Seismic refraction measurements on the continental shelf between Cape Hatteras and Cape Fear: Bulletin of the Seismological Society of America, v. 58, p. $821-834$.

EEZ-Scan '87, 1991, Atlas of U.S. Exclusive Economic Zone, Atlantic Continental Margin: U.S. Geological Survey Miscellaneous Investigations Series I-2054, 174 pp.

Ewing, J.L., and Ewing, M., 1959, Seismic refraction measurements in the Atlantic Ocean basins, in the Mediterranean Sea, on the Mid-Atlantic Ridge, and in the Norwegian Sea: Geological Society of America Bulletin, v. 70, p. 291-318.

Gilbert, L.E., and Dillon, W.P., 1981, Bathymetric map of the Blake Escarpment: U.S. Geological Survey Miscellaneous Field Studies Map MF-1362, 1:250,000, 1 sheet. 
Grim, M.S., Dillon, W.P., and Mattick, R.E., 1980, Seismic reflection, refraction, and gravity measurements from the continental shelf offshore from North and South Carolina: Southeastern Geology, v. 21, p. 239 - 249.

Grow, J.A., Mattick, R.E., and Schlee, J.S., 1979, Multichannel seismic depth sections and interval velocities over outer continental shelf and upper continental slope between Cape Hatteras and Cape Cod, in Watkins, J.S., Montadert, L., and Dickerson, P.W., eds., Geological and geophysical investigations of continental margins: American Association of Petroleum Geologists Memoir 29, p. 65-83.

Hamilton, E.L., 1976a, Sound attenuation as a function of depth in the sea floor: Journal of the Acoustical Society of America, v. 59, p. 528-535.

Hamilton, E.L., 1976b, Attenuation of shear waves in marine sediments: Journal of the Acoustical Society of America, v. 60, p. 334-338.

Hamilton, E.L., 1978, Sound velocity-density relations in sea-floor sediments and rocks: Journal of the Acoustical Society of America: v. 63, p. 366-377.

Hamilton, E.L., 1979, $\mathrm{V}_{\mathrm{p}} / \mathrm{V}_{\mathrm{s}}$ and Poisson's ratios in marine sediments and rocks: Journal of the Acoustical Society of America, v. 66, p. 1093-1101.

Hamilton, E.L., 1980, Geoacoustic modelling of the sea floor: Journal of the Acoustical Society of America, v. 68, p. 1313-1340.

Hamilton, E.L., and Bachman, R.T., 1982, Sound velocity and related properties of marine sediments: Journal of the Acoustical Society of America, v. 72, p. 1891-1904.

Hatcher, R.D., jr., Colquhoun, D.J., Secor, D.T., jr., Cook, F.A., Dillon, W.P., Klitgord, K.D., Popenoe, P., Merschat, C.E., Wiener, L.S., Milici, R.C., Nelson, A.E., Sheridan, R.E., and Snoke, A.W., 1994, North American continent-ocean transect E-4 Cumberland Plateau to Blake Plateau: Geological Society of America Centennial Continent/Ocean Transect \#18, 1:1,000,000, 56 pp.

Hathaway, J.C., 1994, Sediment Database, Sample Collection and Texture Data: Digital Database: U.S. Geological Survey, Woods Hole, MA. (access via the Internet is http://woodshole.er.usgs.gov/data1/SEDIMENTS/hathaway/).

Hathaway, J.C., 1971, Data file - continental margin program Atlantic coast of the United States Vol. 2 - Sample collection and analytical data: Woods Hole Oceanographic Institution Ref. No. 71-15, 496 pp.

Hathaway, J.C., Poag, C.W., Valentine, P.C., Miller, R.R., Schultz, D.M., Manheim, F.T., Kohout, F.A., Bothner, M.H., and Sangrey, D.A., 1979, U.S. Geological Survey core drilling on the Atlantic shelf: Science, v. 206, p. 515-527.

Heezen, B.C., and Sheridan, R.E., 1966, Lower Cretaceous rocks (Neocomian - Albian) 
dredged from Blake Escarpment: Science, v. 154, p. 1644 - 1647.

Hersey, J.B., Bunce, E.T., Wyrick, R.F., and Dietz, F.T., 1959, Geophysical investigation of the continental margin between Cape Henry, Virginia, and Jacksonville, Florida: Geological Society of America Bulletin, v. 70, p. 437-466.

Holbrook, W.S., and Keleman, P.B., 1993, Large igneous province on the U.S. Atlantic margin and implications for magmatism during continental break up: Nature, v. 364 , p. 433 436.

Holbrook. W.S., Reiter, E.C., Purdy, G.H., Sawyer, D., Stoffa, P.L., Austin, J.A. Jr., Oh, J., and Makris, J., 1994, Deep structure of the U.S. Atlantic continental margin, offshore South Carolina, from coincident ocean bottom and multichannel seismic data: Journal of Geophysical Research, v. 99, p. 9155, 9178.

Houtz, R.E., and Ewing, J.I., 1963, Detailed sedimentary velocities from seismic refraction profiles in the western North Atlantic: Journal of Geophysical Research, v. 68, p. 5233 5258.

Hollister, C.D., Ewing, J.I., et al., 1972, Initial Reports of Deep Sea Drilling v. 11: Washington (U.S. Government Printing Office), 1077 pp.

Hutchinson, D.R., Grow, J.A., Klitgord, K.D., and Swift, B.A., 1983, Deep structure and evolution of the Carolina Trough, in Watkins, J.S., and Drake, C.L., eds., Studies in Continental Margin Geology: American Association Petroleum Geologists Memoir 34, p. $129-152$.

Hutchinson, D.R., Poag, C.W., and Popenoe, P., 1995, Geophysical database of the East Coast of the United States: Southern Atlantic margin - stratigraphy and velocity from multichannel seismic profiles: U.S. Geological Survey Open-File Report OF 95-27, 180 pp.

Kekko, B., Kelly, E., Ross, C., and Rogers, R., 1992, Results of laboratory analyses for fourteen cores collected off Florida coastline during the January - February 1991 USNS Kane Cruise 270290: Naval Oceanographic Office Marine Geological Laboratory Report No. 738.

Klitgord, K.D., and Behrendt, J.C., 1979, Basin structure of the U. S. Atlantic margin: American Association Petroleum Geologists Memoir 29, p. 85-112.

Klitgord, K.D., Hutchinson, D.R., and Schouten, H., 1988, U.S. Atlantic continental margin; Structural and tectonic framework, in Sheridan, R.S., and Grow, J.A., eds., The Atlantic Continental Margin, U.S., The Geology of North America, v. I-2, Geological Society of America, v. I-2, ch. 3, p. 19-55.

Klitgord, K.D., Poag, C.W., Schneider, C.M., and North, L., 1994, Geophysical database of the East Coast of the United States northern Atlantic continental margin: cross sections and 
gridded database (Georges Bank basin, Long Island platform, and Baltimore Canyon trough): U.S. Geological Survey Open-File Report 94-637, 187 p.

Klitgord, K.D., and Schneider, C.M., 1994, Geophysical Database of the East Coast of the United States Northern Atlantic Margin: Velocity Analyses, U.S. Geological Survey, Open File Report \#94-192, 74 pp.

Kvenvolden, K.A., 1993, Gas hydrates - geological perspective and global change: Reviews of Geophysics, v. 31, p. $173-187$.

Lee, M.W., Hutchinson, D.R., Agena, W.F., Dillon, W.P., Miller, J.J., and Swift, B.A., 1994, Seismic Character of Gas Hydrates on the Southeastern U.S. Continental Margin: Marine Geophysical Researches 16: p. 163-184.

Leg 44 Shipboard Scientific Party, 1978, Site 391: Blake Bahama Basin, in Benson, W.E., Sheridan, R.E., and others, Initial reports of the Deep Sea Drilling Project, Leg 44: Washington (U.S. Government Printing Office), p. 153-336.

Markl, R.G., and Bryan, G.M., 1983, Stratigraphic evolution of the Blake Outer Ridge: American Association of Petroleum Geologists Bulletin, v. 67, p. 666-683, 1488-1490.

Markl, R.G., Bryan, G.M., and Ewing, J.L., 1970, Structure of the Blake-Bahama outer ridge: Journal of Geophysical Research, v. 75, p. 4539-4555.

Mitchell, S.K., and Focke, K.C., 1980, New measurements of compressional-wave attenuation in deep ocean sediments: Journal of the Acoustical Society of America, v. 67, p. 15821589 .

Mountain, G.S., and Tucholke, B.E., 1985, Mesozoic and Cenozoic geology of the Atlantic continental slope and rise, in Poag, C.W., ed., Geologic evolution of the United States Atlantic margin: New York, Van Nostrand Reinhold, p. 293-341.

NOS (National Ocean Service), 1986, Bathymetric Map of the Atlantic Ocean, southeastern United States: Washington (U.S. Department of Commerce, National Oceanic and Atmospheric Administration), 1:1,000,000.

Palmer, A.W., 1983, The Decade of North American Geology 1983 - Geologic Timescale: Geology, v. 11, p. 503-504.

Paull, C.K., Popenoe, P., Dillon, W.P., and McCarthy, S.M., 1980, Geologic subcrop map of the Florida-Hatteras shelf and slope and inner Blake Plateau. U.S. Geological Survey Miscellaneous Field Studies Map MF-1171, 1;500,000.

Payton, C.E., ed., 1977, Seismic stratigraphy - Applications to hydrocarbon exploration: American Association of Petroleum Geologists Memoir 26, 516 pp.

Pinet, P.R., Popenoe, P., and Nelligan, D.F., 1981, Reconstruction of Cenozoic flow patterns 
over the Blake Plateau: Geology, v. 9, no. 6, p. 266-270.

Poag, C.W., 1978, Stratigraphy of the Atlantic continental shelf and slope of the United States: Annual Review of Earth and Planetary Sciences, v. 6, p. $251-280$.

Poag, C.W., 1985, Depositional history and stratigraphic reference section for central Baltimore Canyon Trough, in Poag, C.W., ed., Geologic Evolution of the United States Atlantic Margin: p. 217-263.

Poag, C.W., 1991, Rise and demise of the Bahama-Grand Banks gigaplatform, northern margin of the Jurassic proto-Atlantic seaway, Marine Geology, 102, p. 63-130.

Poag, C.W., and Schlee, J.S., 1984, Depositional sequences and stratigraphy gaps on submerged United States Atlantic margin, in Schlee, J.S., ed., Interregional Unconformities and Hydrocarbon Accumulation, The American Association of Petroleum Geologists Memoir 36, p. 165-182.

Poag, C.W., and Valentine, P., 1988, Mesozoic and Cenozoic stratigraphy of the United States Atlantic continental shelf and slope, in Sheridan, R.S. and Grow, J.A., eds., The Atlantic Continental Margin, U.S., The Geology of North America, Vol. I-2, Geological Society of America, p. 67-85.

Poag, C.W., and Ward, L.W., 1993, Allostratigraphy of the U.S. Middle Atlantic Continental Margin--characteristics, distribution and depositional history of principal unconformitybounded Upper Cretaceous and Cenozoic sedimentary units: U.S. Geological Survey Professional Paper 1542, $81 \mathrm{pp}$.

Popenoe, P. 1985, Cenozoic depositional and structural history of the North Carolina margin from seismic-stratigraphic analyses, in Poag, C.W., ed., Geologic Evolution of the United States Atlantic Margin: New York, Van Nostrand Reinhold Co., Inc., p. 125187.

Popenoe, P., 1987, Paleo-oceanography and paleogeography of the Miocene of the southeastern United States, in Burnett, W.C., and Riggs, S.R., eds., World phosphate deposits, Volume 3, Neogene phosphorites of the southeastern United States: Cambridge University Press.

Popenoe, P., 1993, Bottom Character of the northeastern Blake Plateau. U.S. Geological Survey Open File Report 93-724, 36p.

Poppe, L.J., ed., 1981, Data File - Atlantic Margin Coring Project (AMCOR) of the U.S. Geological Survey: U.S. Geological Survey Open-File Report 81-239, 96 pp.

Rankin, D.W., Dillon, W.P., Black, D.F.B., Boyer, S.E., Daniels, D.L., Goldsmith, R., Grow, J.A., Horton, J.W., jr., Hutchinson, D.R., Klitgord, K.D., McDowell, R.C., Milton, D.J., Owens, J.P., and Phillips, J.D.. 1991, North American continent-ocean transect E-4 Central Kentucky to the Carolina trough: Geological Society of America Centennial 
Continent/Ocean transect \#16, 1:1,000,000, $41 \mathrm{pp}$.

Schlager, W., Bourgeois, F., Mackenzie, G., and Smit, J., 1988, Boreholes at Great Isaac and site 626 and the history of the Florida Straits, in Austin, J.A., Jr., and Schlager, W., et al., Proceedings of the Ocean Drilling Program, Scientific Results, v. 101, p. 425-437.

Scholle, P.A., ed., 1979, Geological studies of the COST GE-1 well, United States outer continental shelf area: U.S. Geological Survey Circular 800, $114 \mathrm{pp}$.

Sheridan, R.E., Berman, R.M., and Corman, D.B., 1971, Faulted limestone block dredged from Blake Escarpment: Bulletin Geological Society of America, v. 82, p. $199-206$.

Sheridan, R.E., Crosby, J.T., Bryan, G.M., and Stoffa, P.L., 1981, Stratigraphy and structure of the southern Blake Plateau, northern Florida Straits and northern Bahama Platform from multichannel seismic-reflection data: American Association of Petroleum Geologists Bulletin, v. 65, p. 2571 - 2593.

Sheridan, R.E., Drake, C.L., Nafe, J.E., and Hennion, J., 1966, Seismic refraction study of continental margin east of Florida: American Association of Petroleum Geologists Bulletin, v. 50, p. 1972 - 1991.

Sheridan, R.E., and Enos, P., 1979, Stratigraphic evolution of the Blake Plateau after a decade of scientific drilling, in Talwani, M., Hay, W., and Ryan, W.B.F., eds., Deep drilling results in the Atlantic Ocean: Continental margins and paleoenvironment: Maurice Ewing Series, v. 3, American Geophysical Union Geophysical Monograph, p. 109-122.

Sheridan, R.E., Gradstein, F.M., et al., 1983, Initial Reports of Deep Sea Drilling Program v. 76: Washington (U.S. Government Printing Office), $947 \mathrm{pp}$.

Sheridan, R.A., Grow, J.A., and Klitgord, K.D., 1988, Geophysical data, in Sheridan R.S., and Grow, J.A., eds., The Atlantic Continental Margin, U.S., The Geology of North America, v. I-2, Geological Society of America, p. 177-196.

Smith, W.H.F., and Wessel, P., 1990, Gridding with continuous curvature splines in tension: Geophysics, v. 55, p. 293-305.

Stoll, R.D., 1980, Theoretical aspects of sound transmission in sediments: Journal of the Acoustical Society of America, v. 68, p. 1341-1350.

Stoll, R.D., 1985, Acoustic waves in ocean sediments: Geophysics, v. 42, p. 715-725.

Tator, B.A., and Hatfield, L.E., 1975a, Bahamas present complex geology (Part 1): Oil and Gas Journal, v. 73(43), p. 172 - 176.

Tator, B.A., and Hatfield, L.E., 1975b, Bahamas present complex geology (Part 2): Oil and Gas Journal, v. 73(44), p. 120 - 122. 
Trehu, A.M., Ballard, A., Dorman, L.M., Gettrust, J.F., Klitgord, K.D., and Schreiner, A., 1989, Structure of the lower crust beneath the Carolina trough, U.S. Atlantic Margin: Journal of Geophysical Research, v. 94, p. 10,585 - 10,600.

Vail, P.R., Mitchum, R.M., Jr., Todd, R.G., Widmier, J.M., Thompson III, S., Sangree, J.B., Bubb, J.N., and Hatlelid, W.G., 1977, Seismic stratigraphy and global changes of sealevel, in Payton, C.E., ed., Seismic stratigraphy - Applications to hydrocarbon exploration: American Association of Petroleum Geologists Memoir 26, p. 49 - 212.

Wessel, P., and Smith, W.H.F., 1991, Free software helps map and display data: Transactions of the American Geophysical Union, EOS, v. 72, pp. 441, 445-446.

Wise, R.A., and Oliver, H.L., 1988, Reprocessing of marine multichannel seismic reflection profile line 12, Cape Hatteras, North Carolina, to Shell Mohawk Well, Canada: U.S. Geological Survey Open-File Report 88-51, 17 pp.

Woollard, G.P., Bonini, W.E., and Meyer, R.P., 1957, A seismic refraction study of the subsurface geology of the Atlantic Coastal Plain and continental shelf between Virginia and Florida: University of Wisconsin Technical Report, Contract No. N7ONR-28512, $128 \mathrm{pp}$.

Wright, E.L., and Hosom, J.P., 1986, Seismic-reflector database software, Steiger, D., ed., Proceedings: IEZEE, 1986 Working Symposium on Oceanographic Data Systems, La Jolla, California, p. 184-190. 


\section{APPENDIX 1}

\section{Gridded Data - Isochron Maps}

In this appendix are maps showing the travel time (isochron) through units $20-190$. The contour interval for all maps is .1 seconds. The isochron of the water column is identical to that of the structure map in time of the seafloor (Appendix 4). 


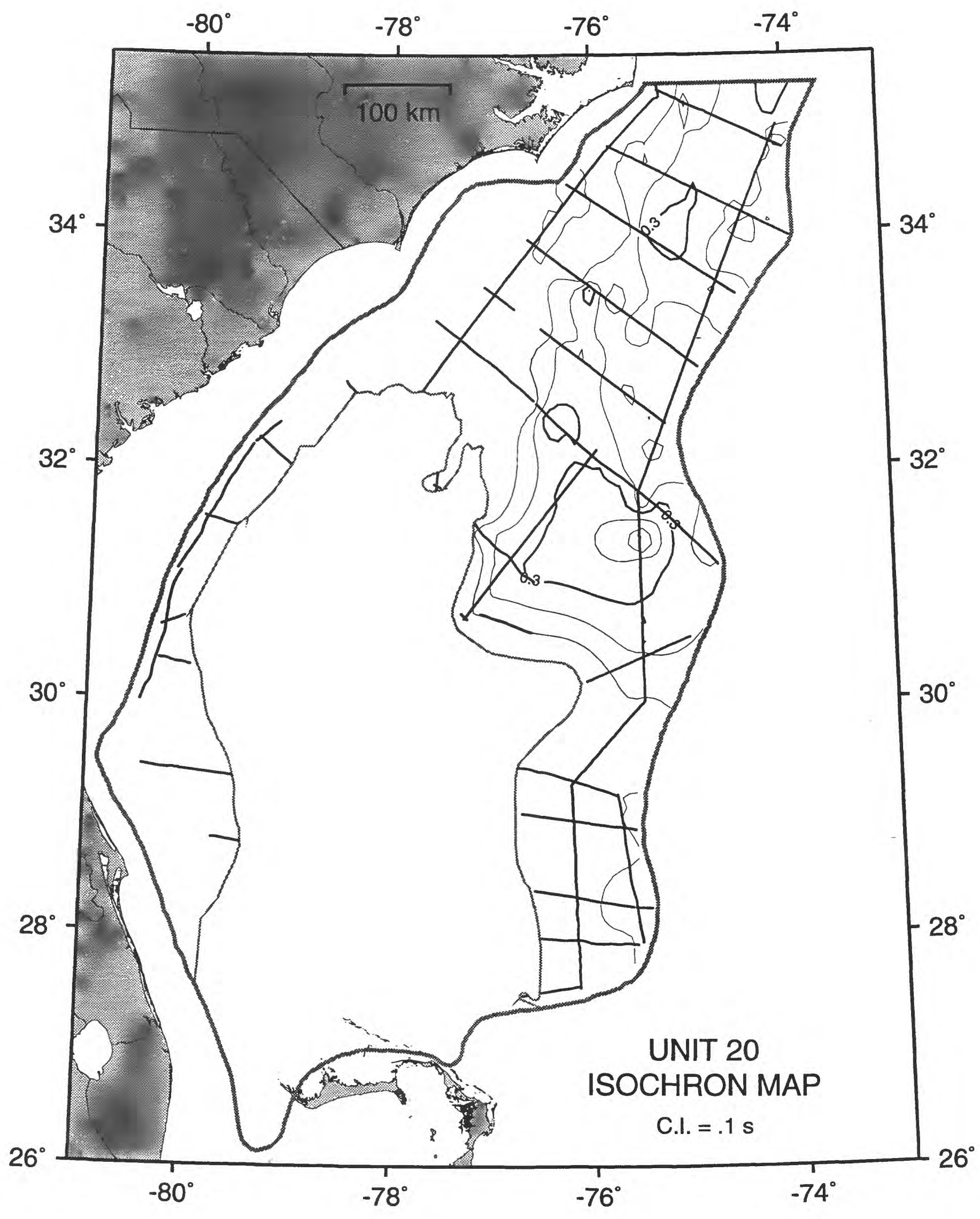




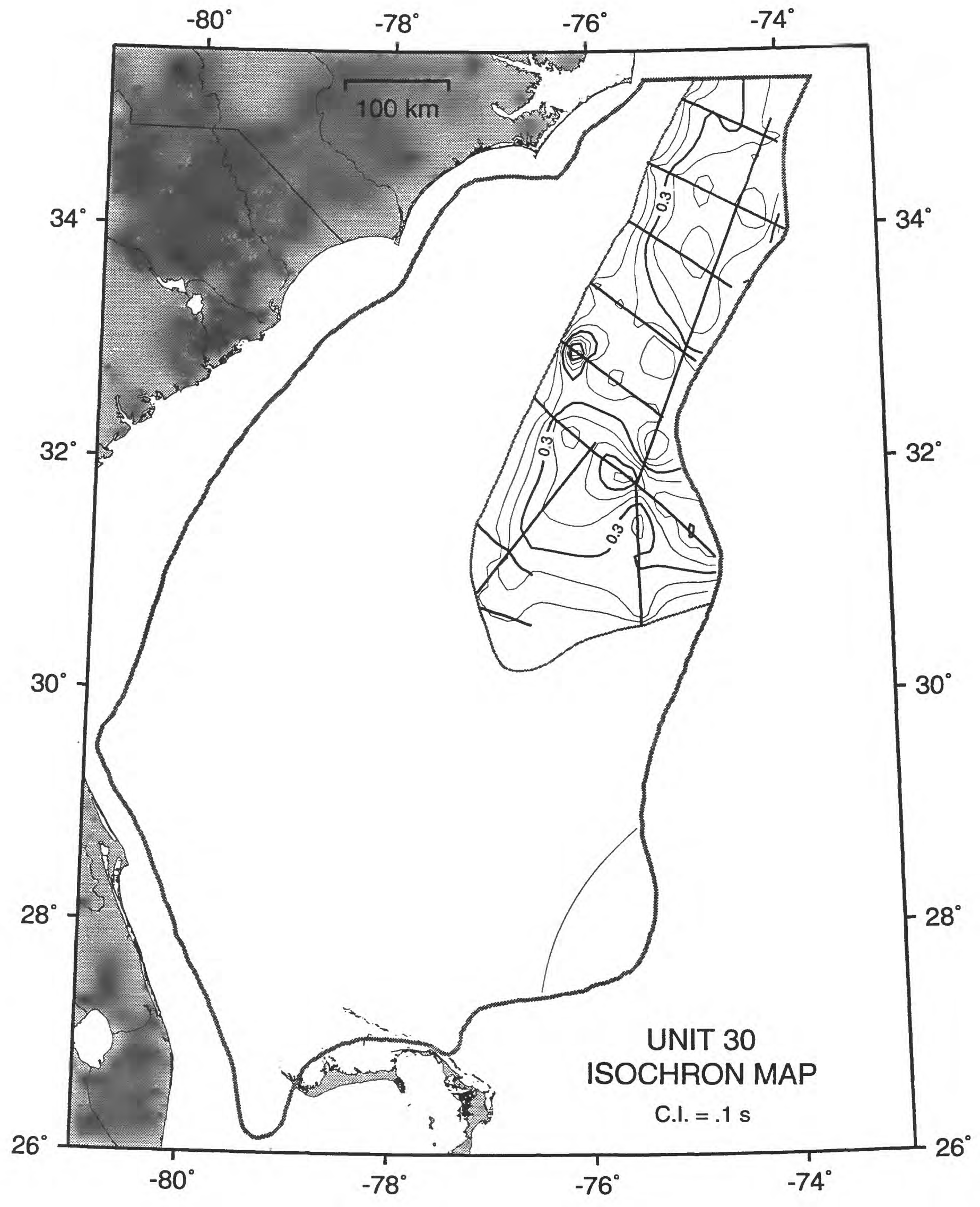




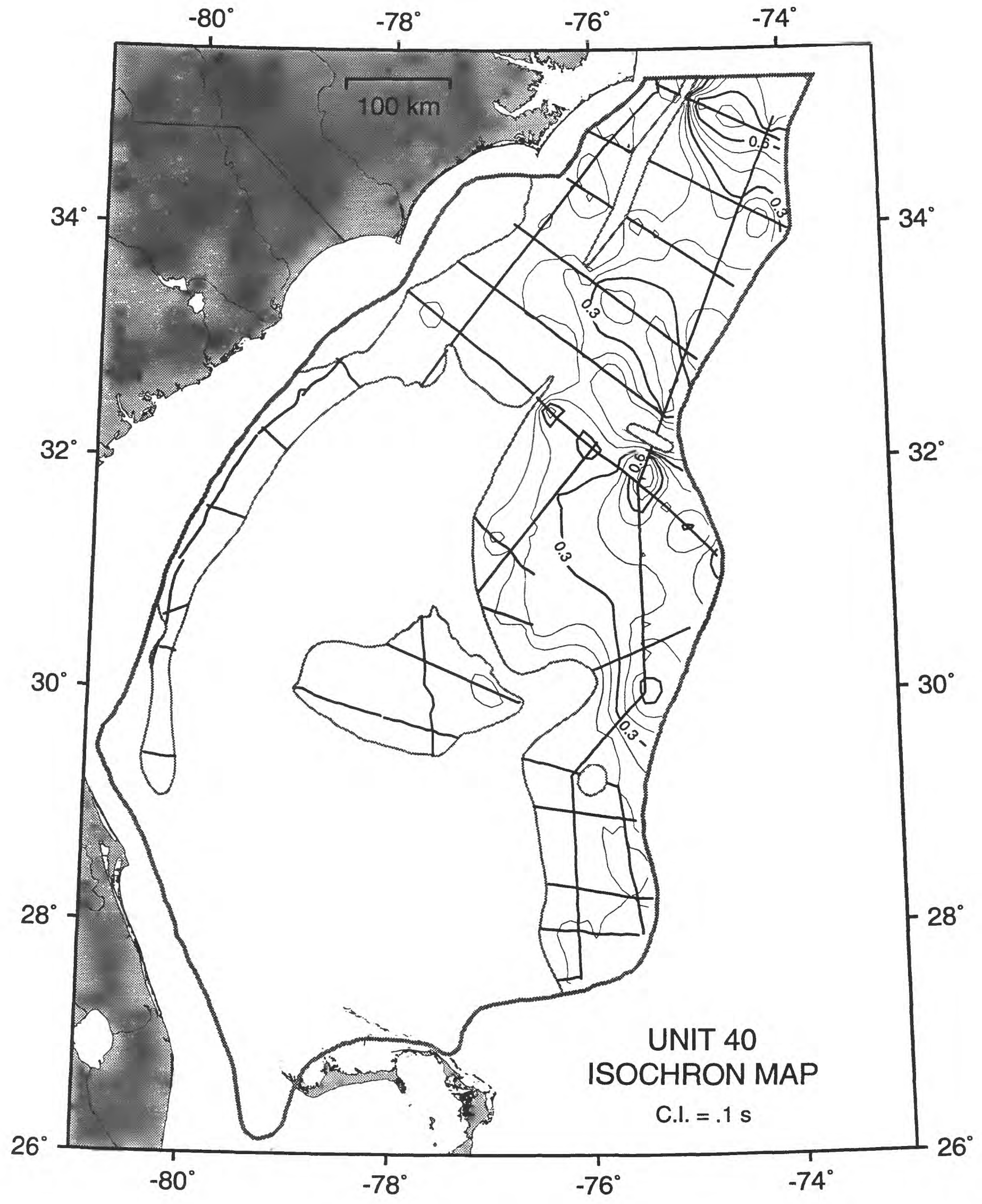




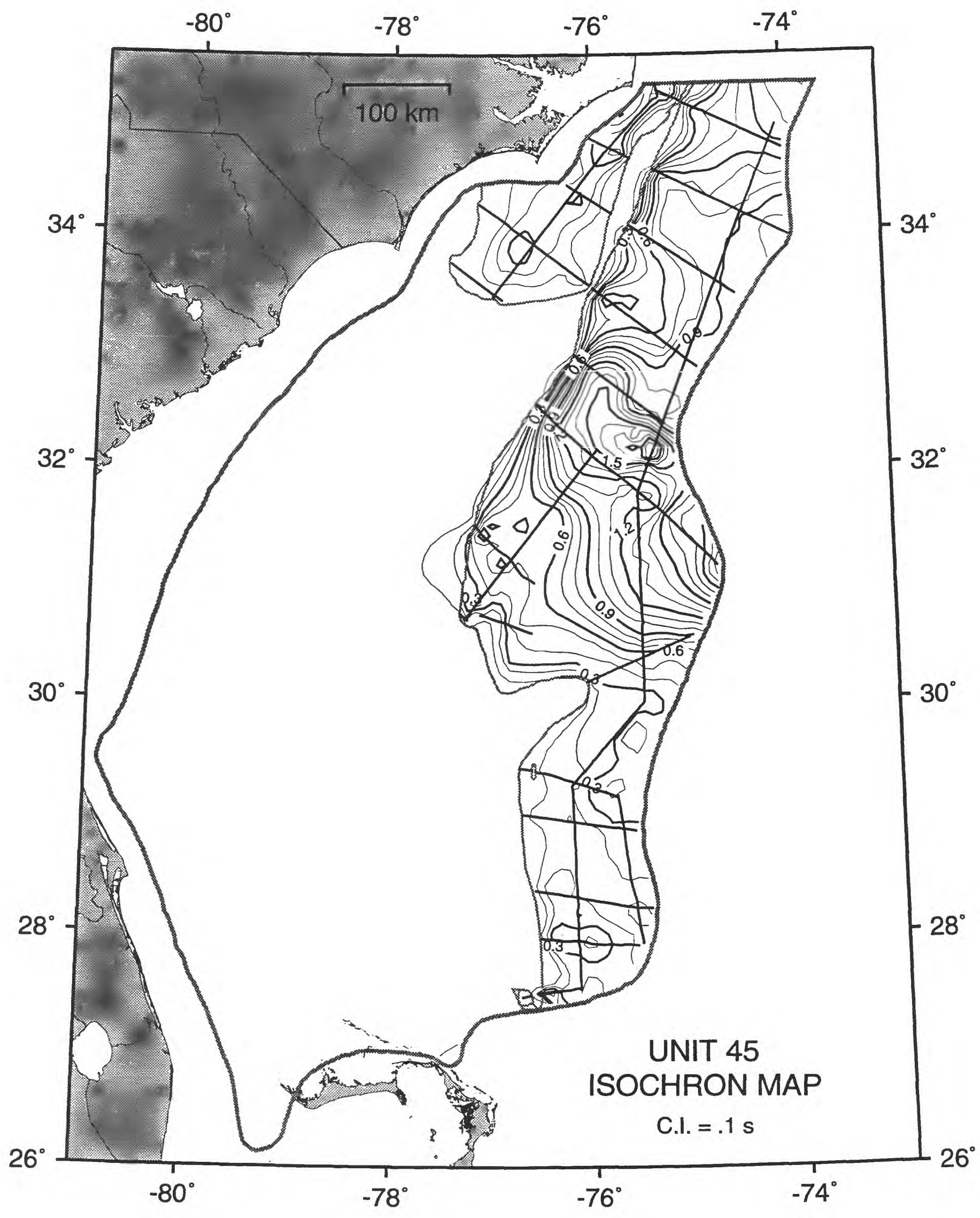




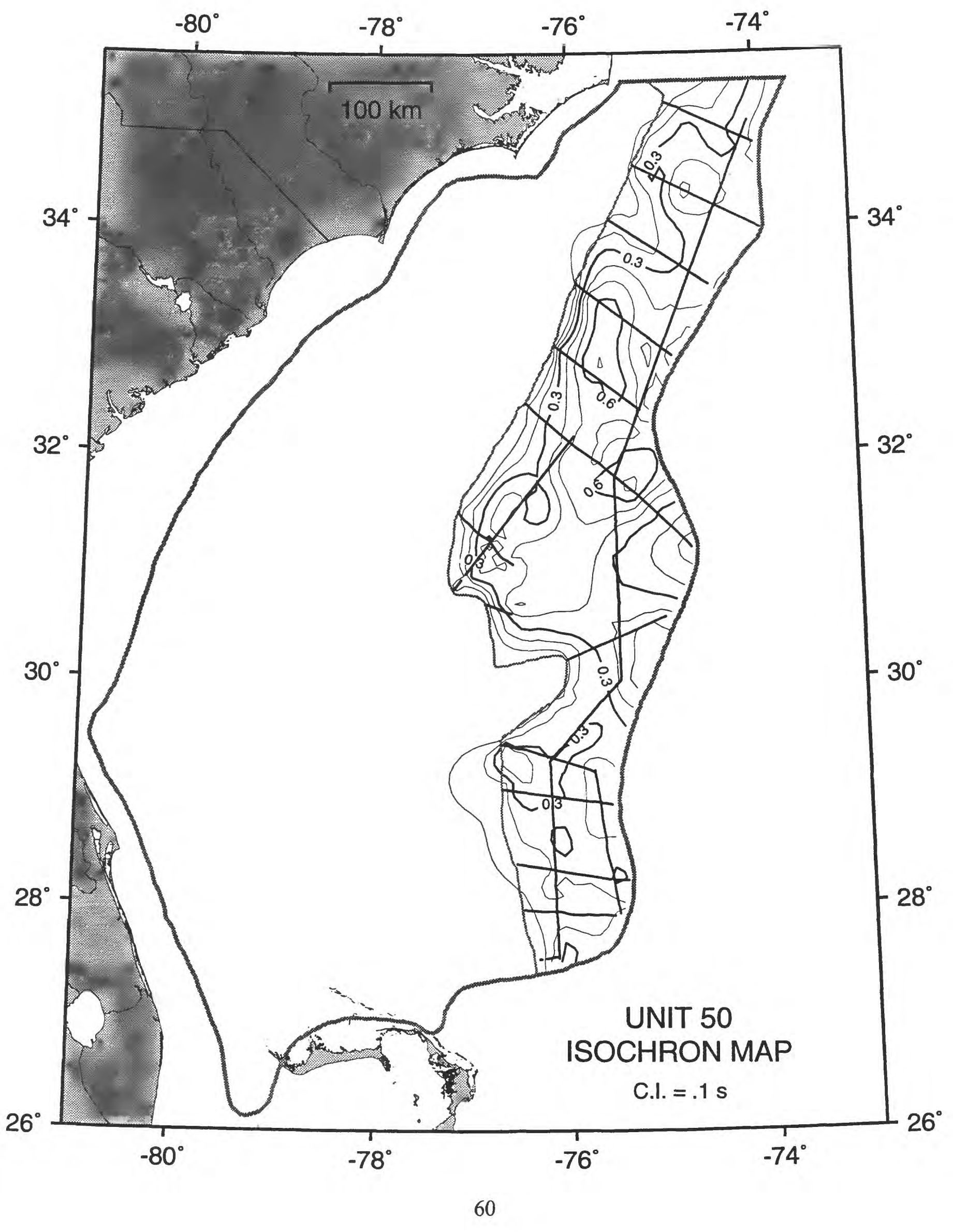




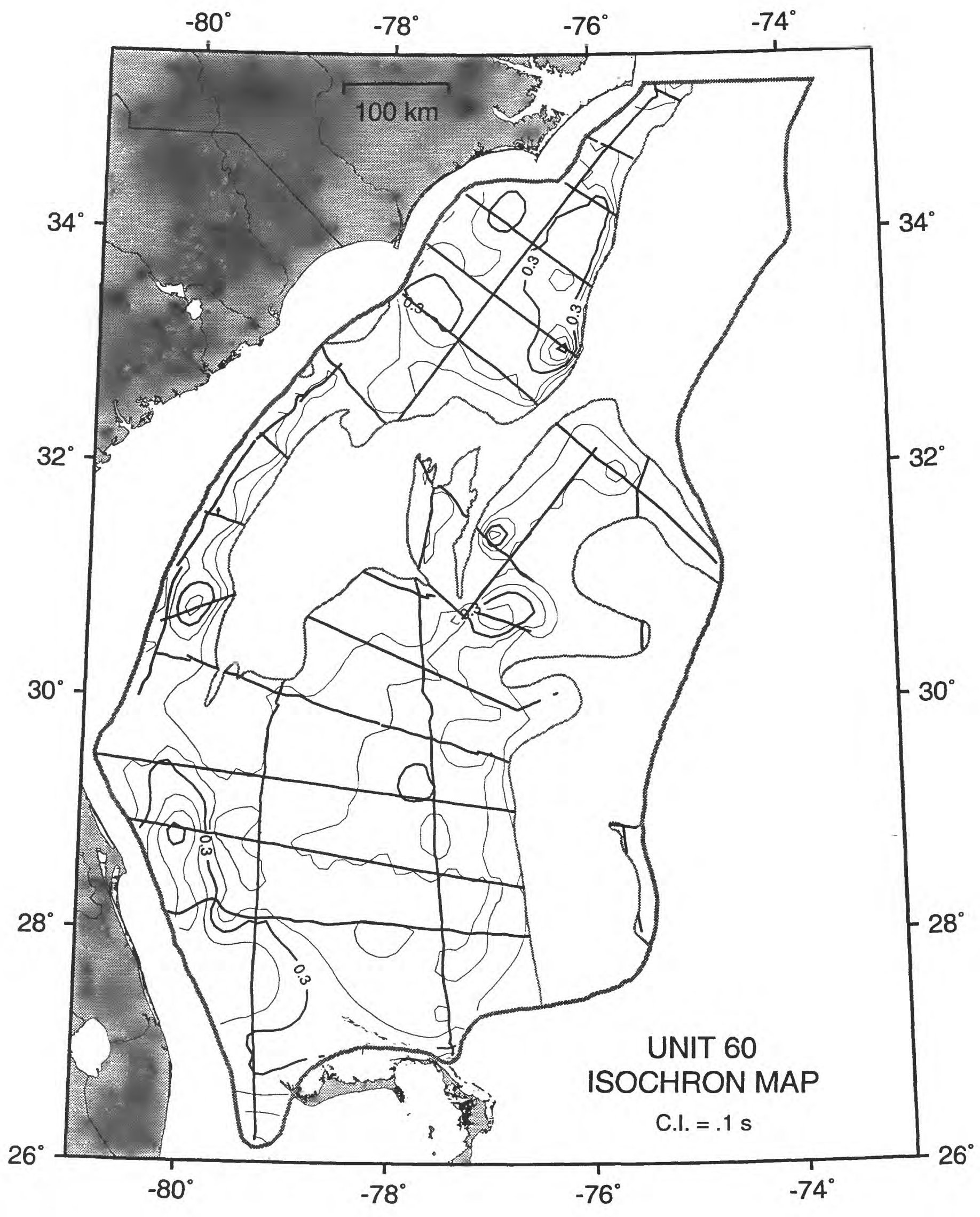




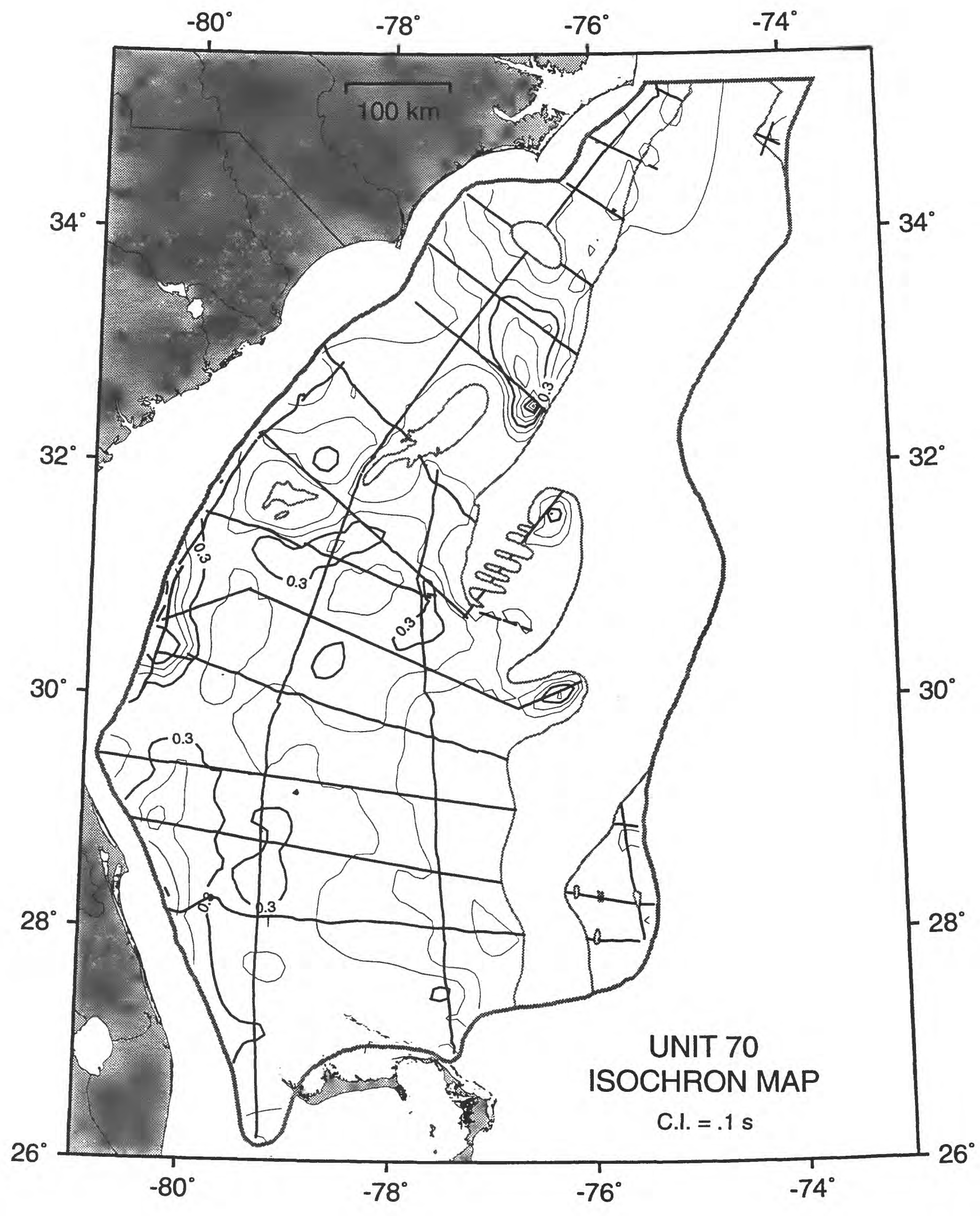




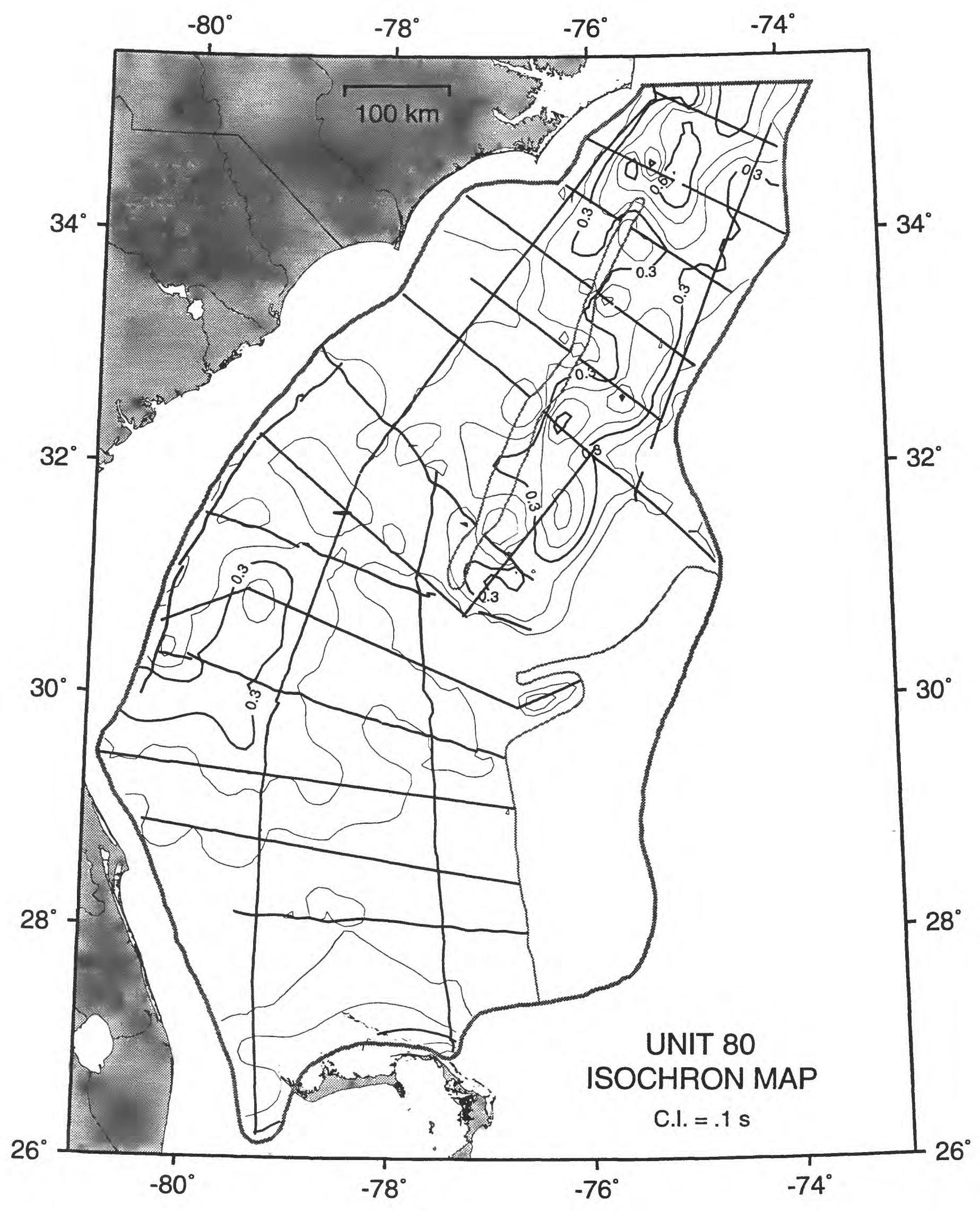




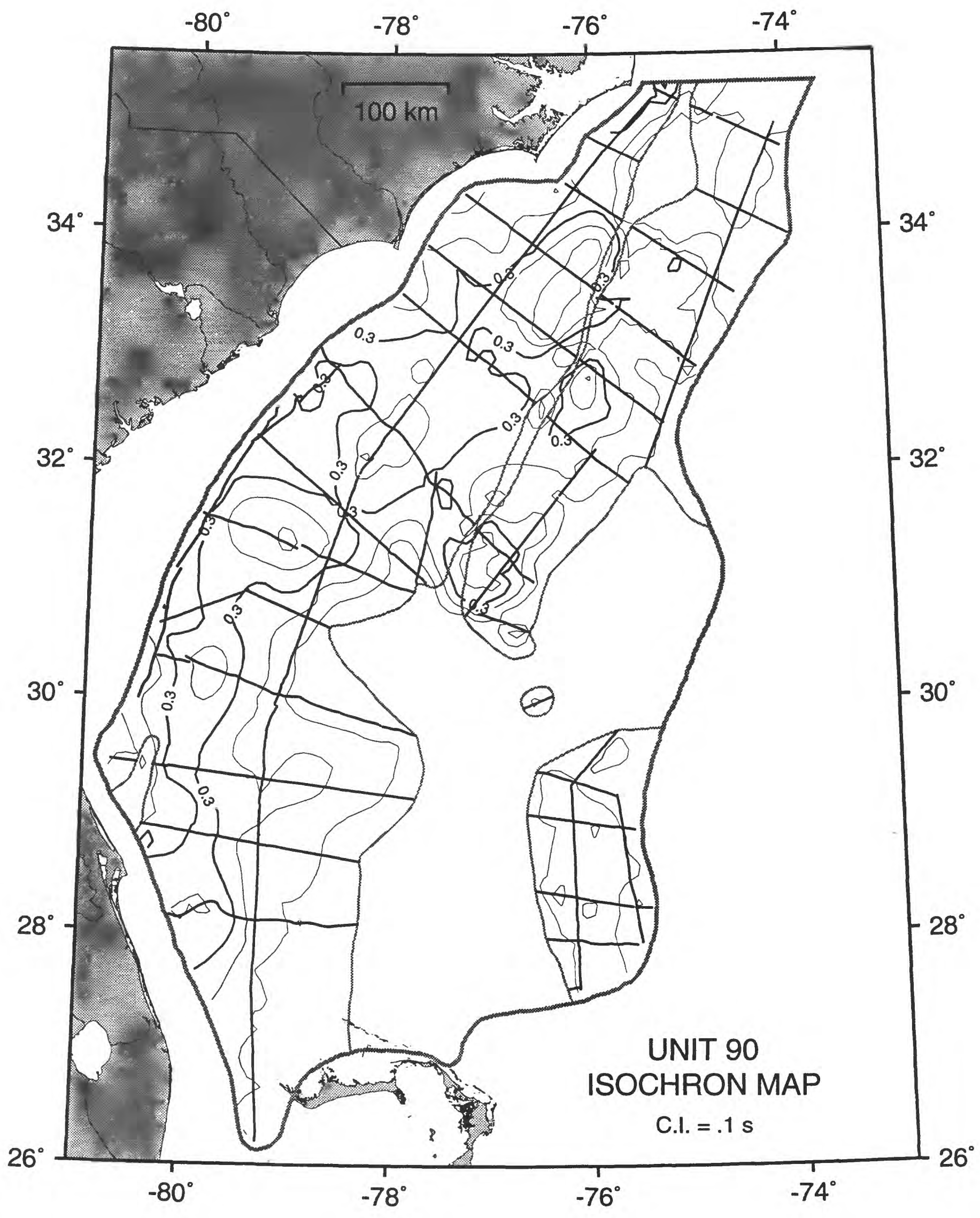




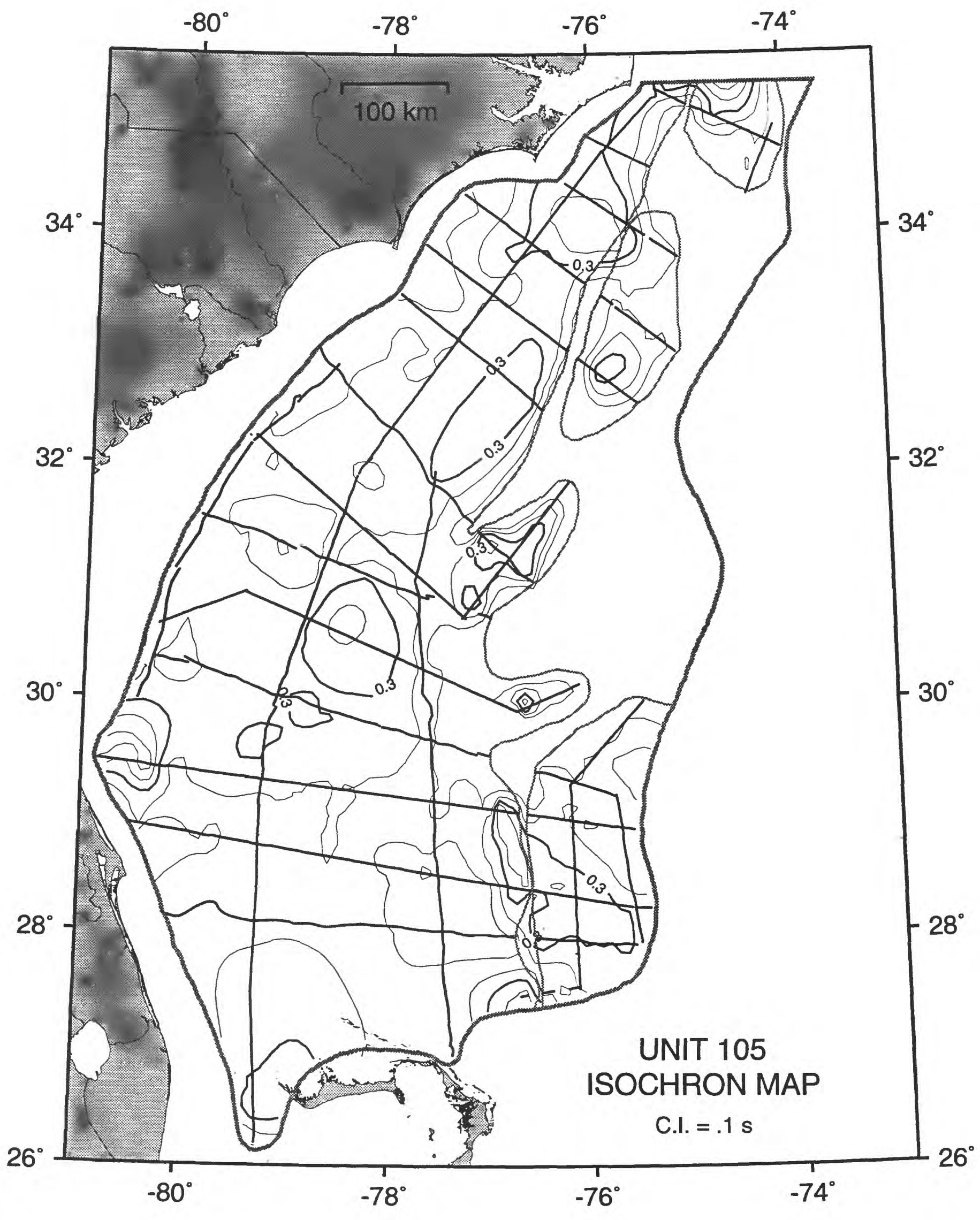




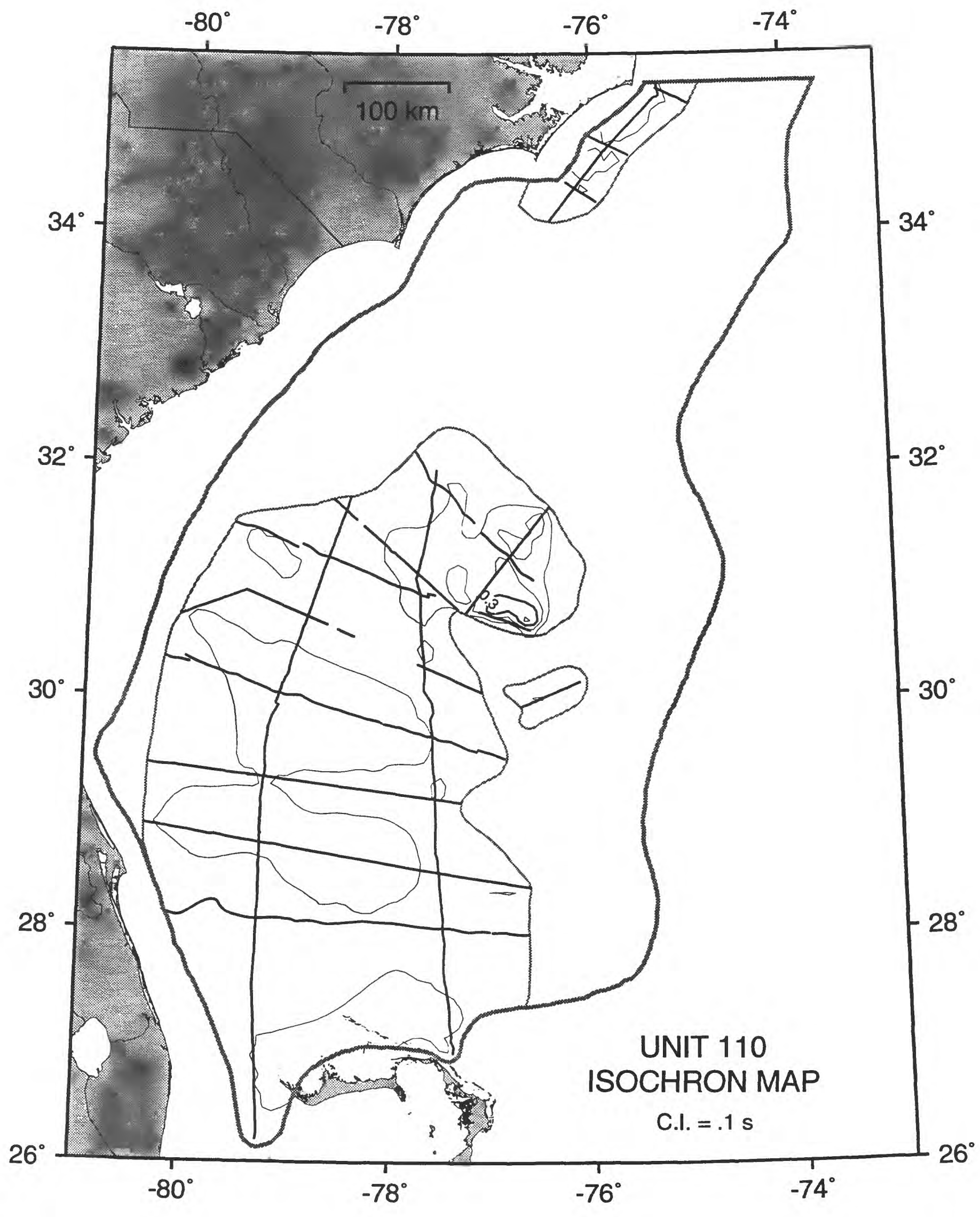




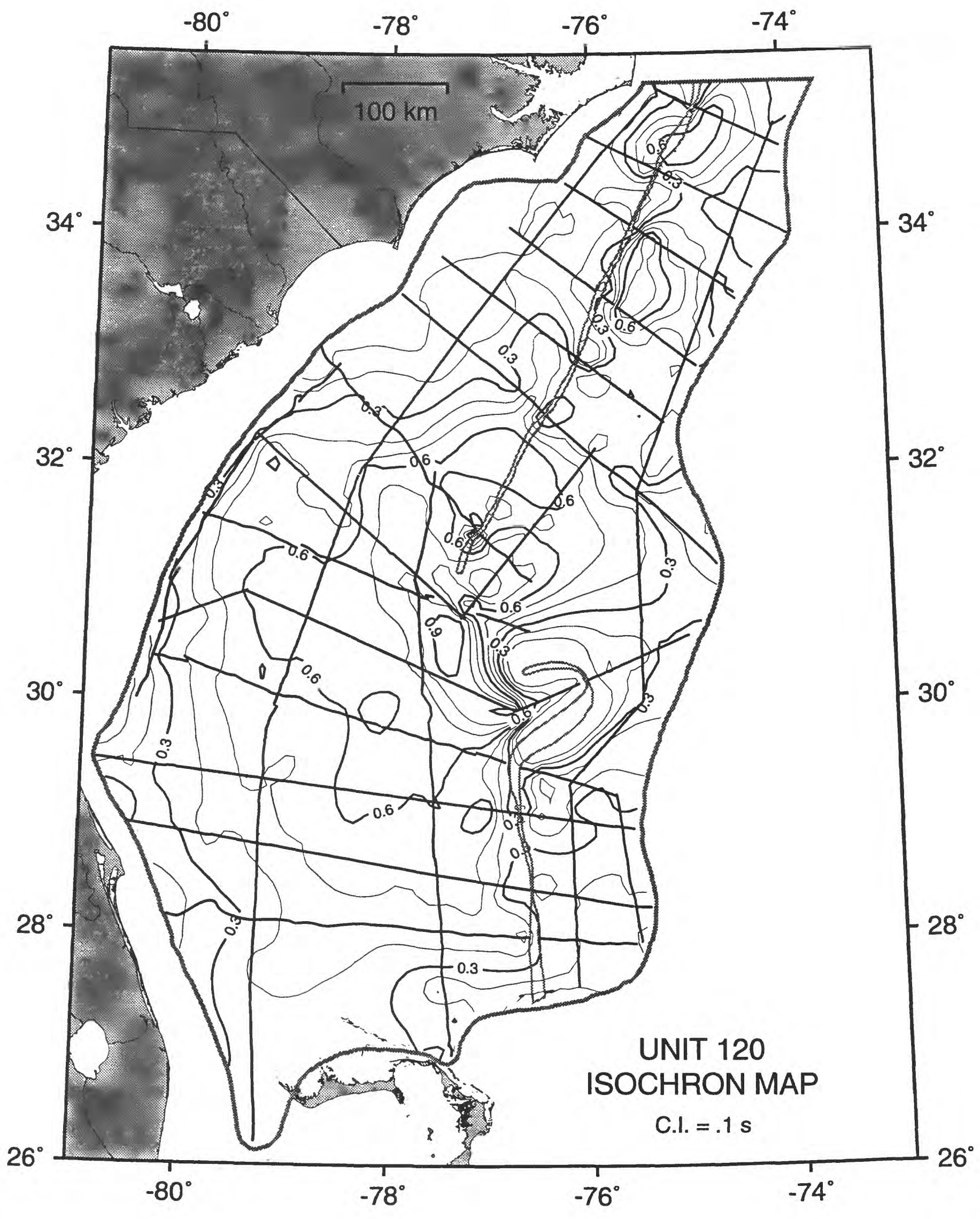




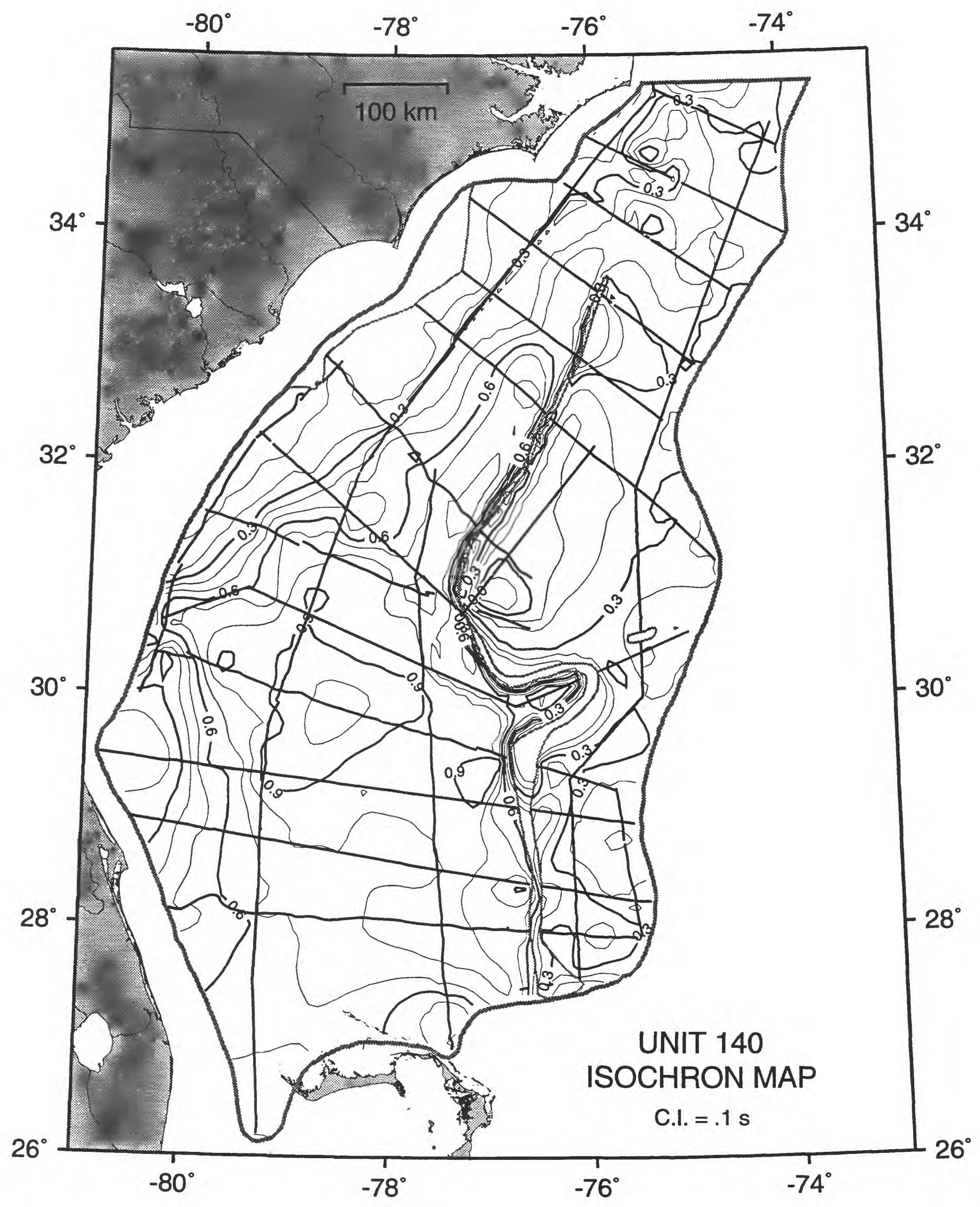




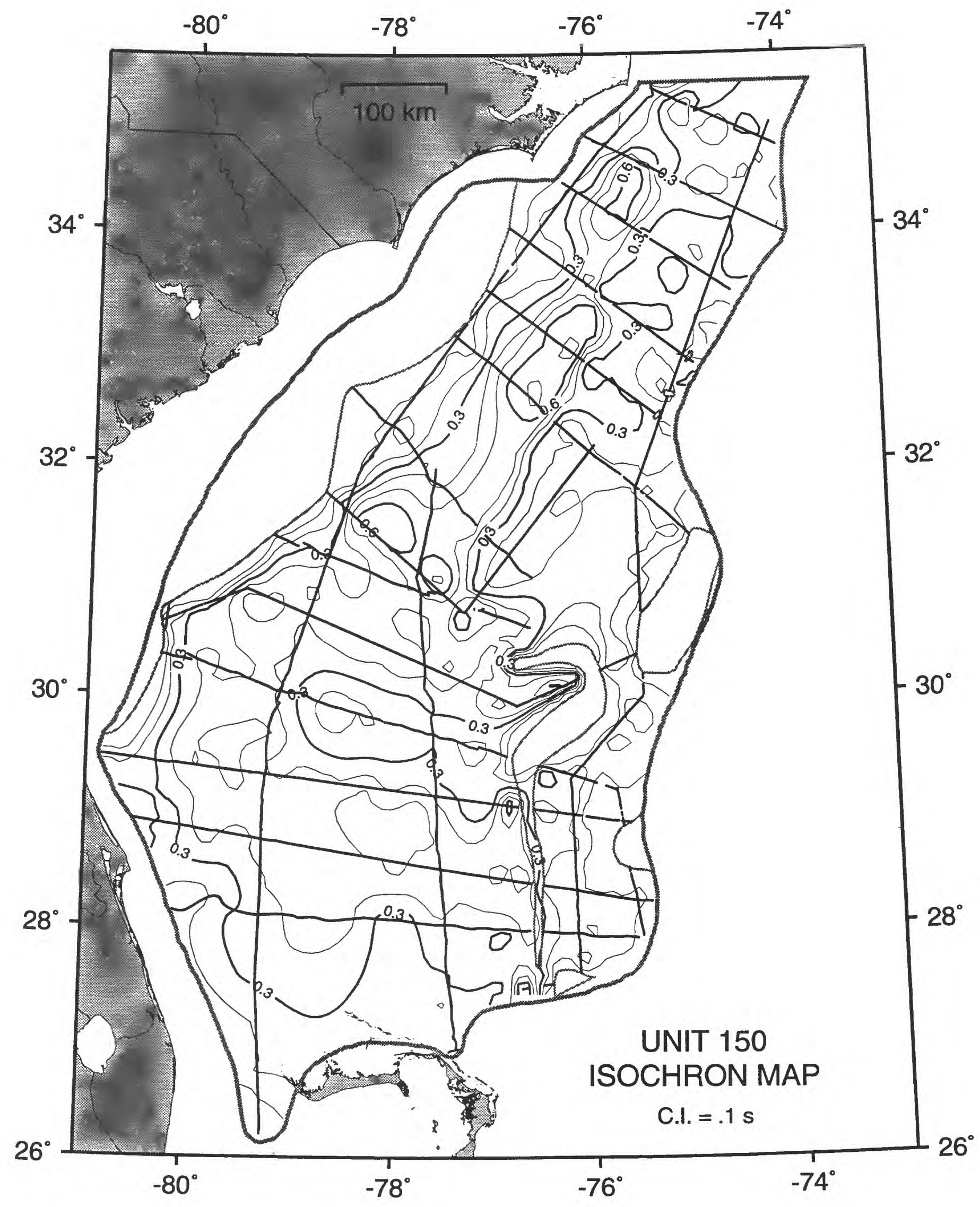




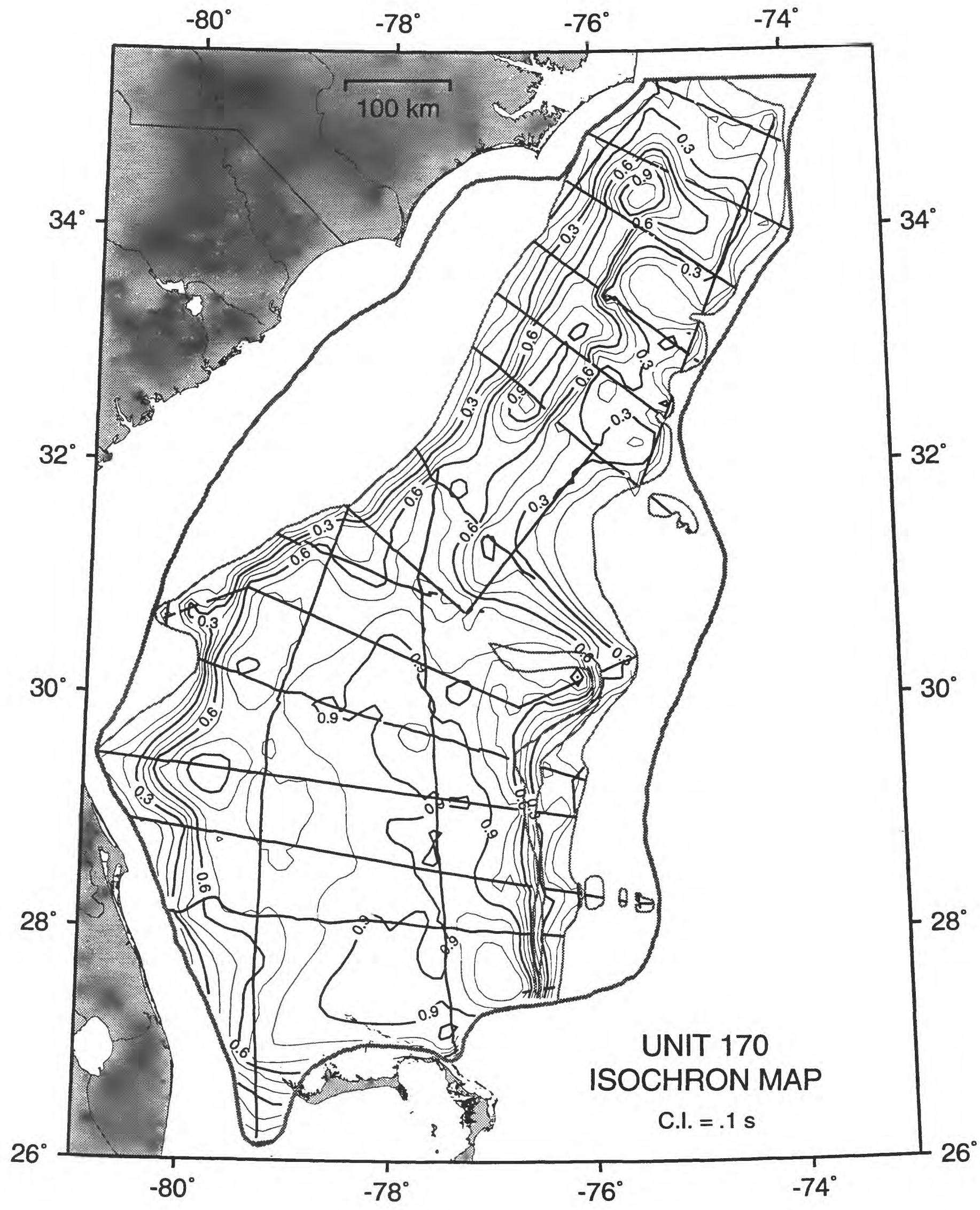




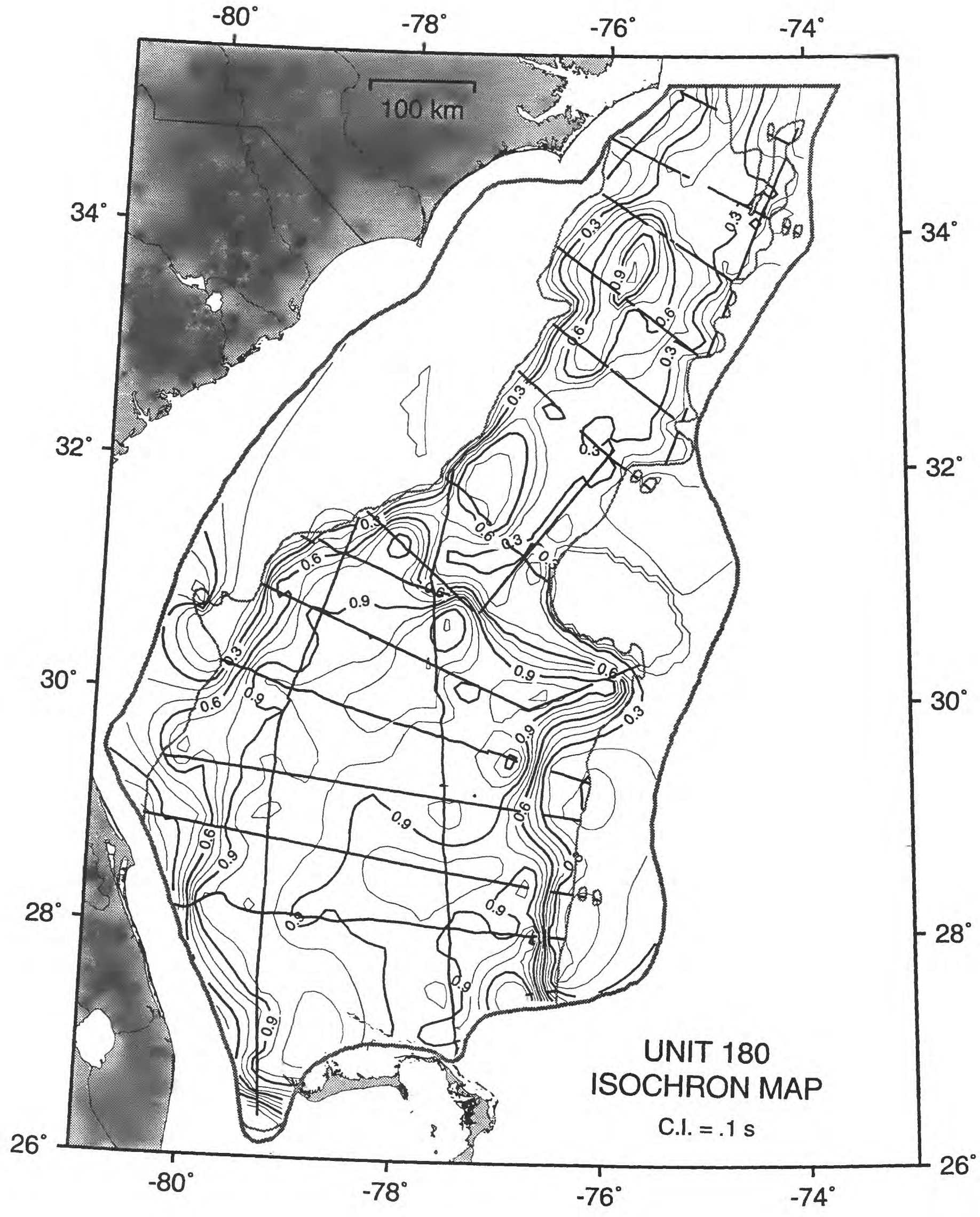




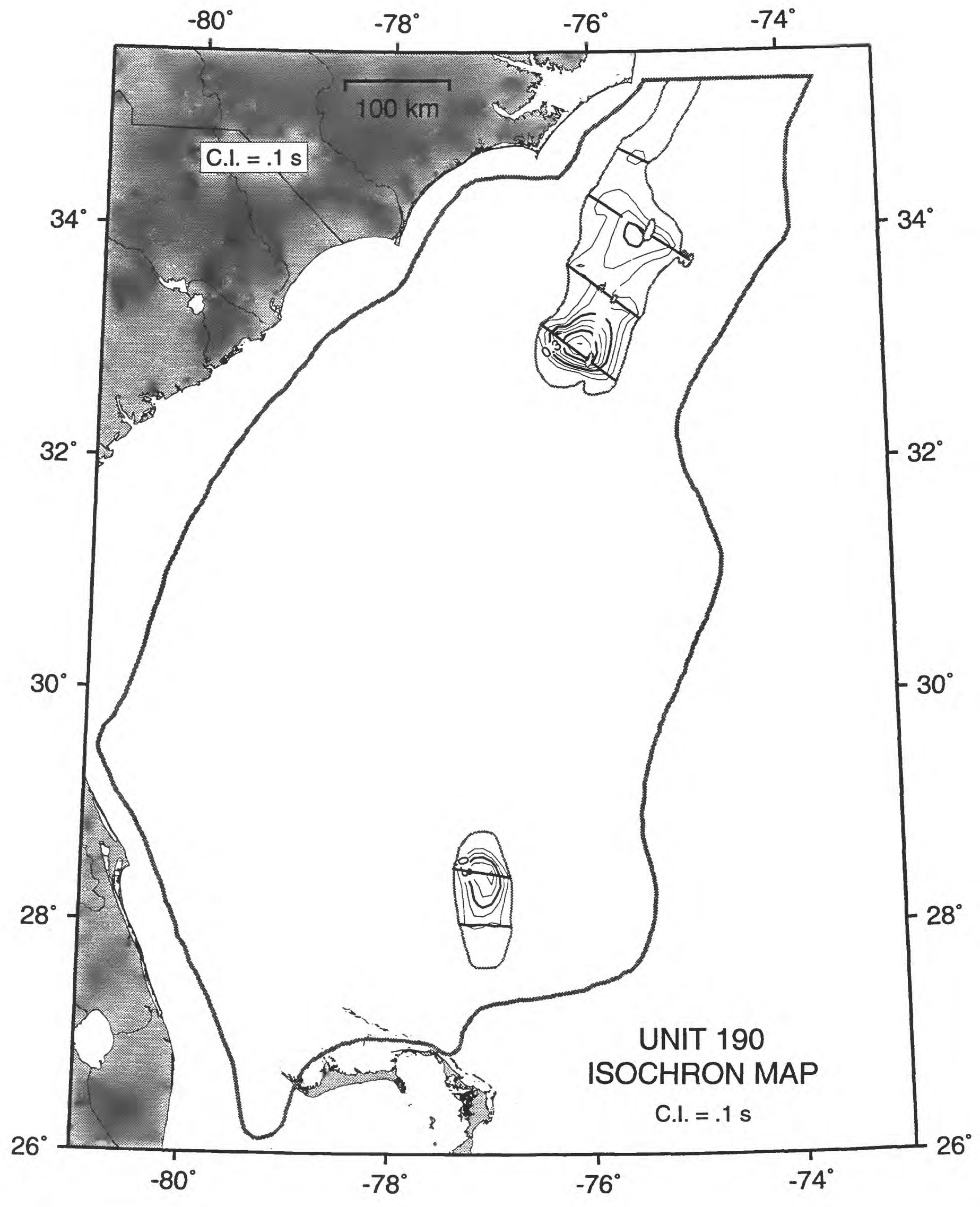




\section{APPENDIX 2}

\section{Gridded Data - Interval Velocity Maps}

Maps of interval velocity for each acoustic unit are shown in this appendix. Tracklines of the seismic profiles used to constrain the velocities are shown by heavy black line segments. Regions where the unit is absent are not contoured. The velocity of the water column above the sea floor is assumed to be constant at $1500 \mathrm{~m} / \mathrm{s}$. Contour interval is $50 \mathrm{~m} / \mathrm{s}$. 


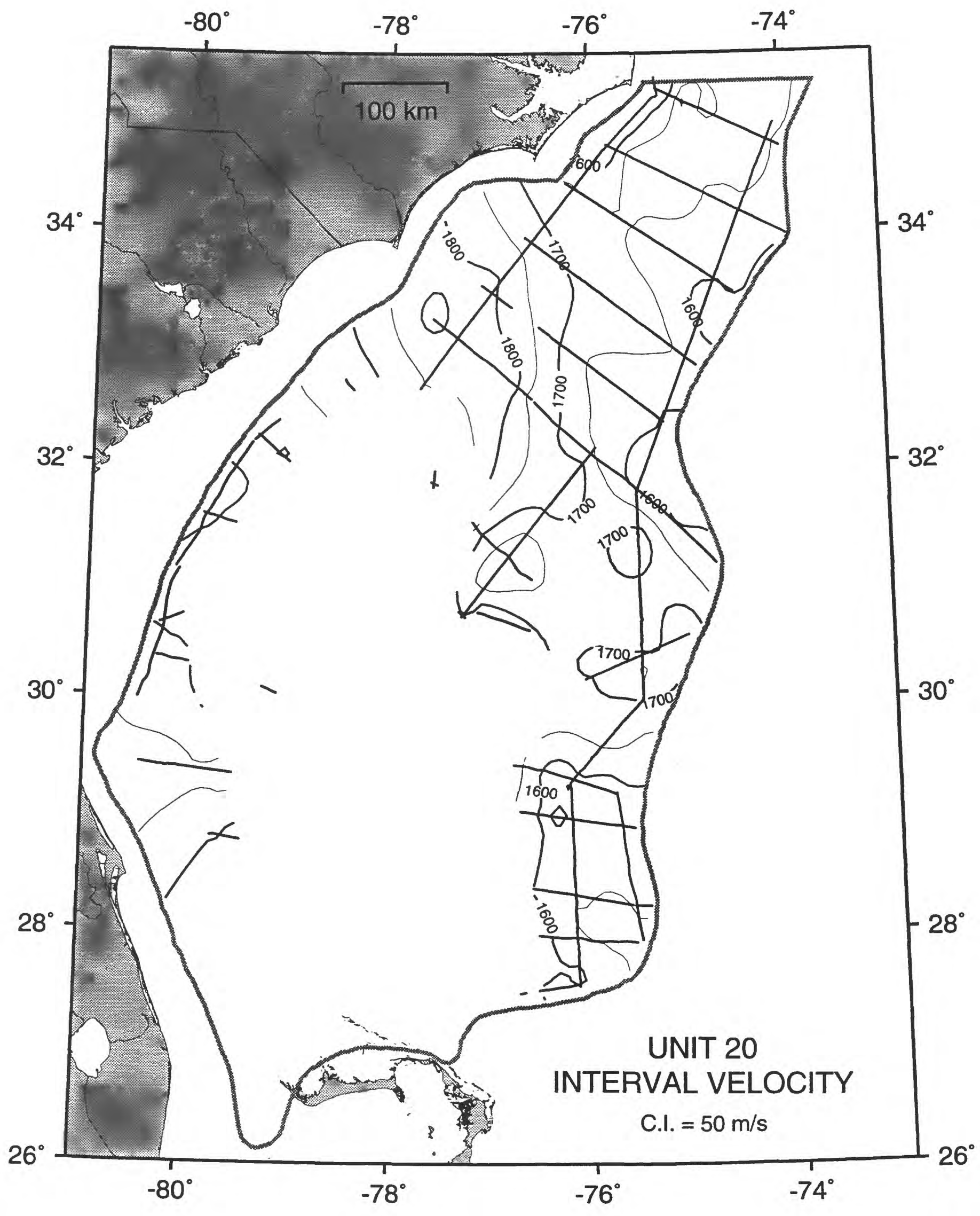




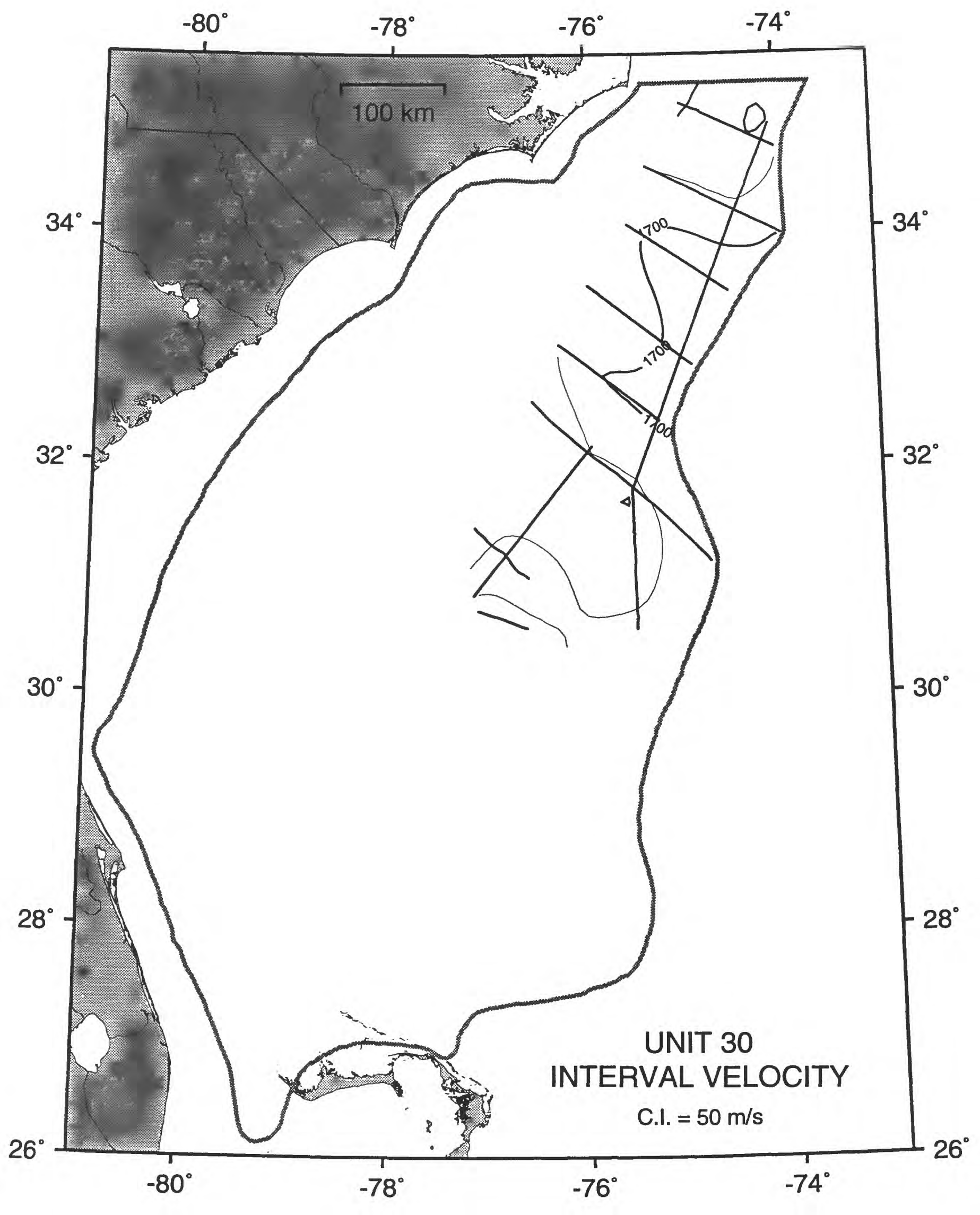




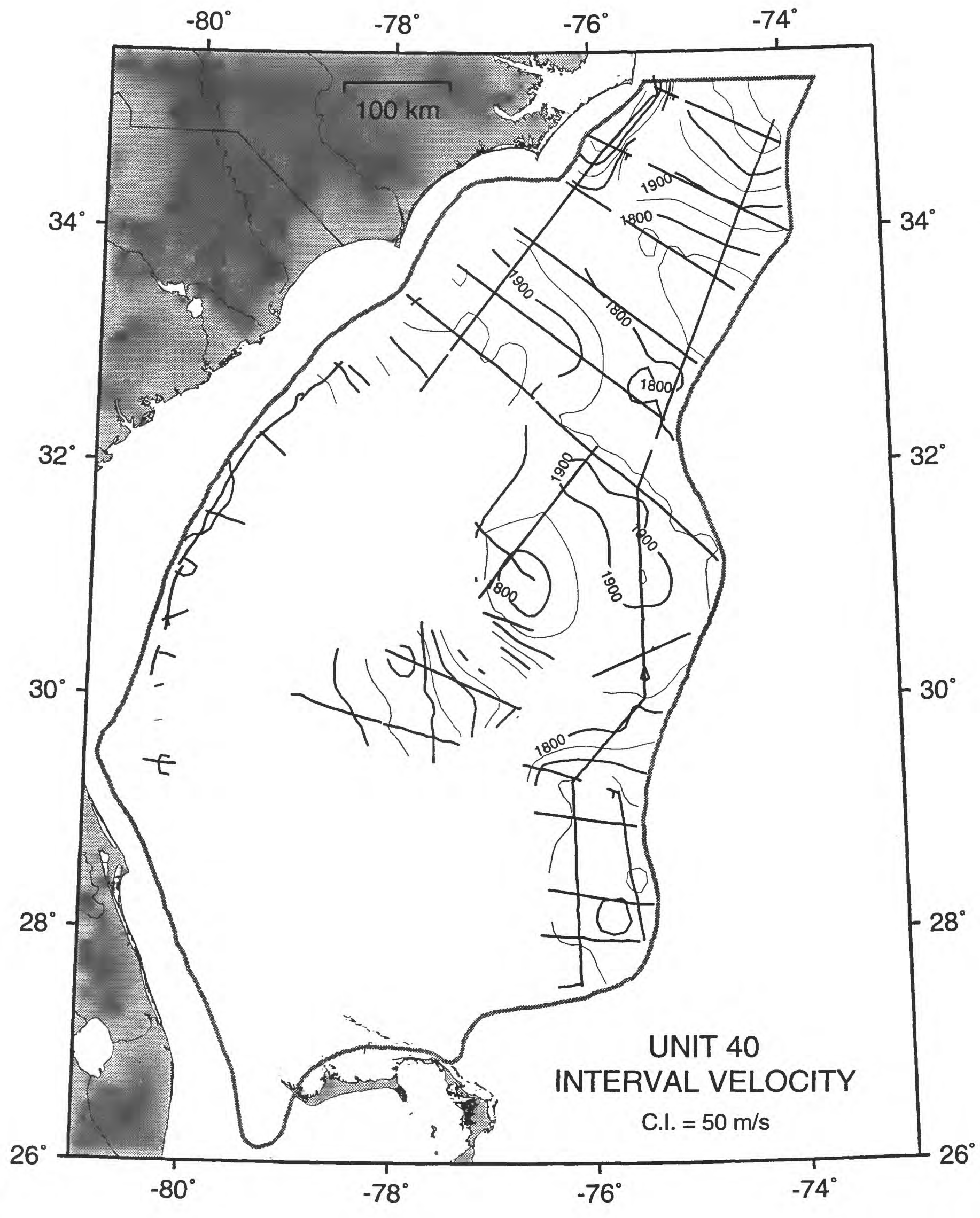




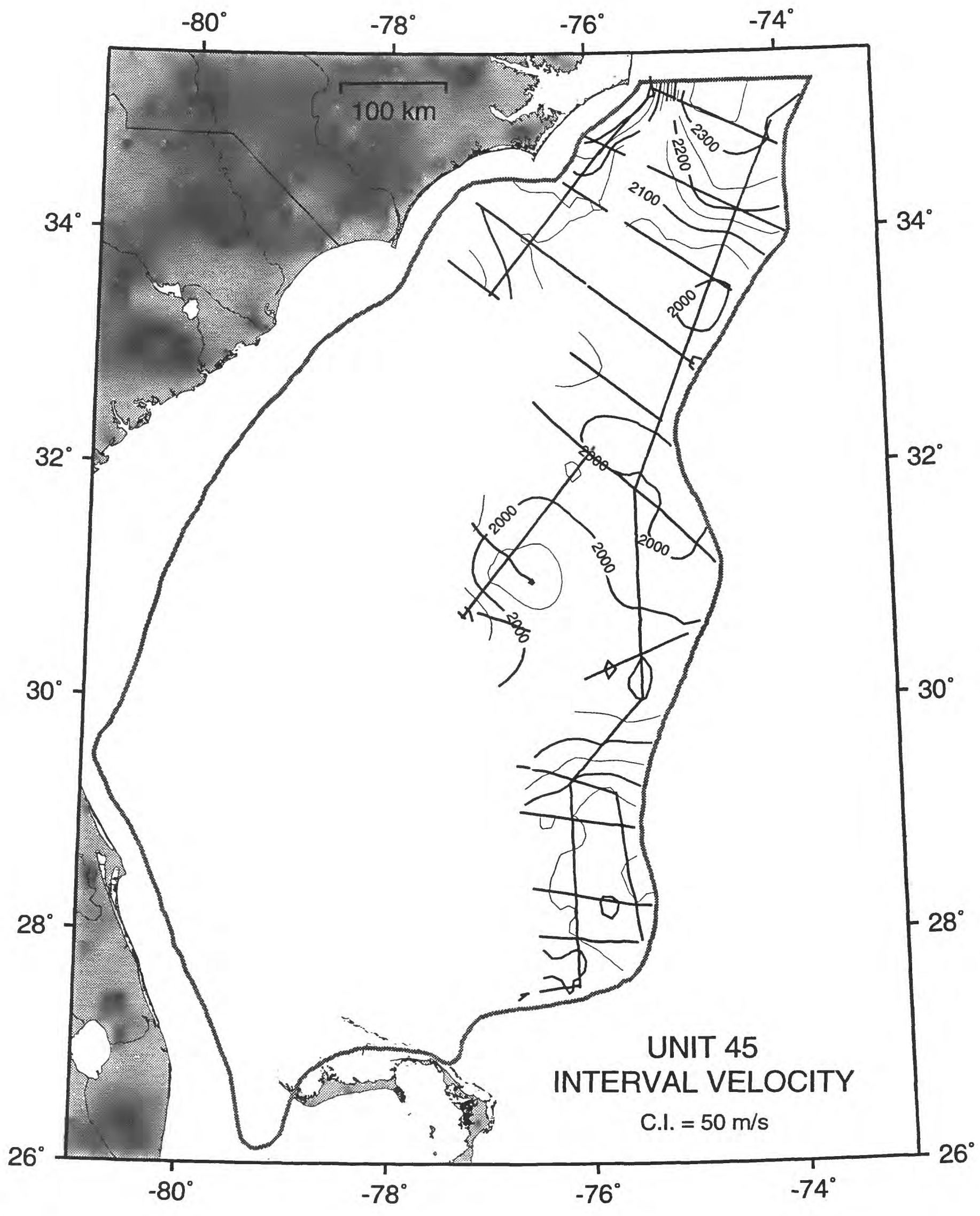




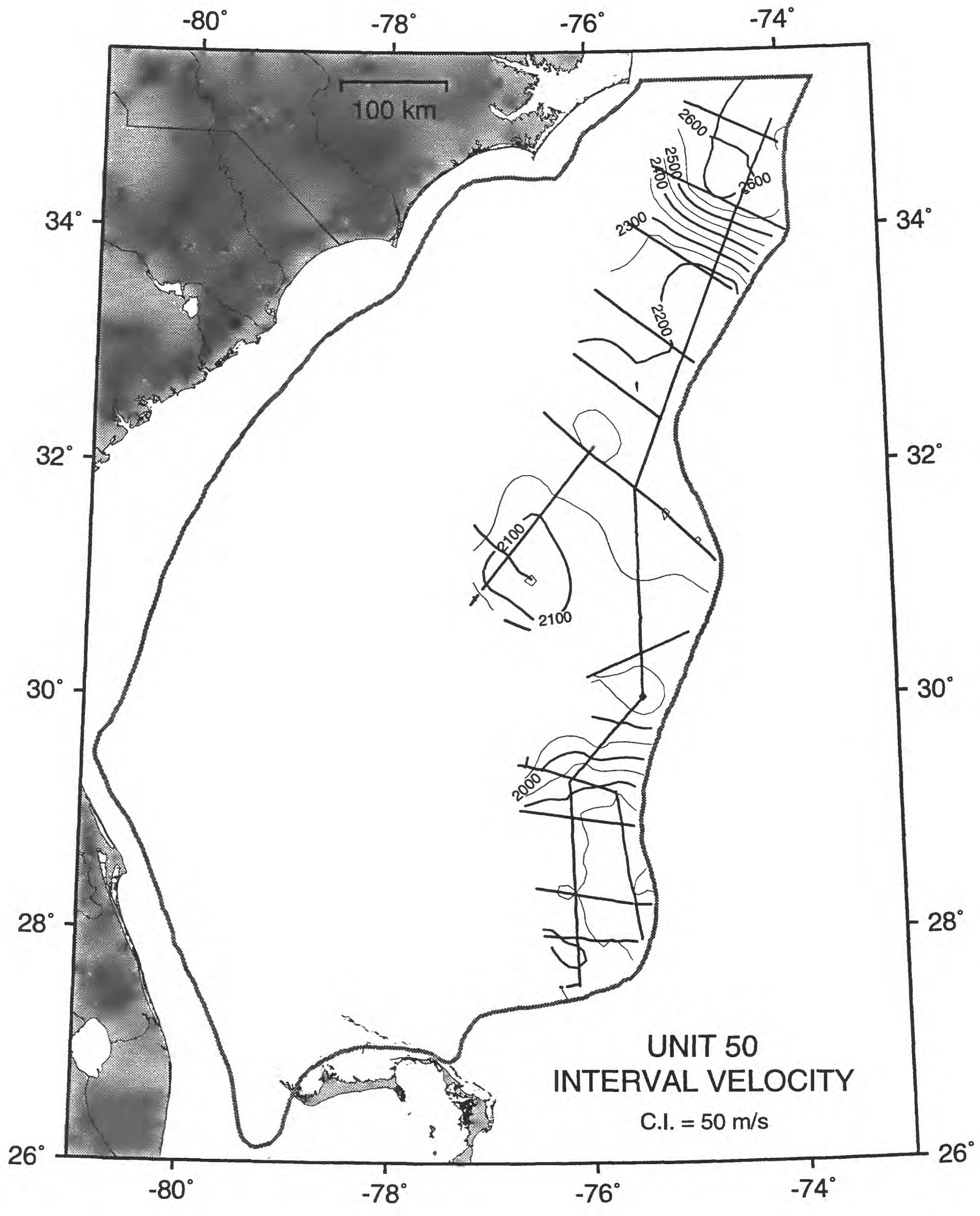




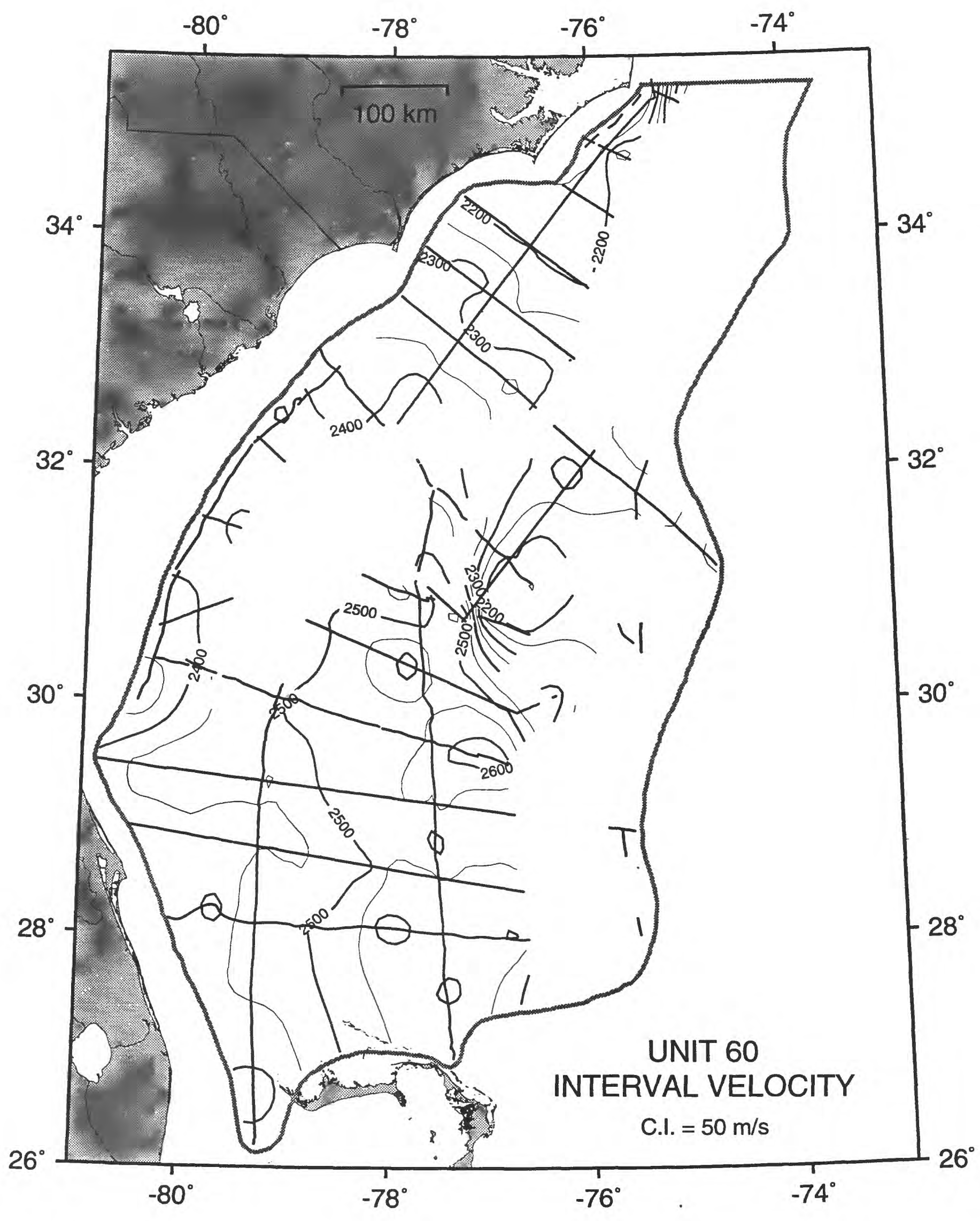




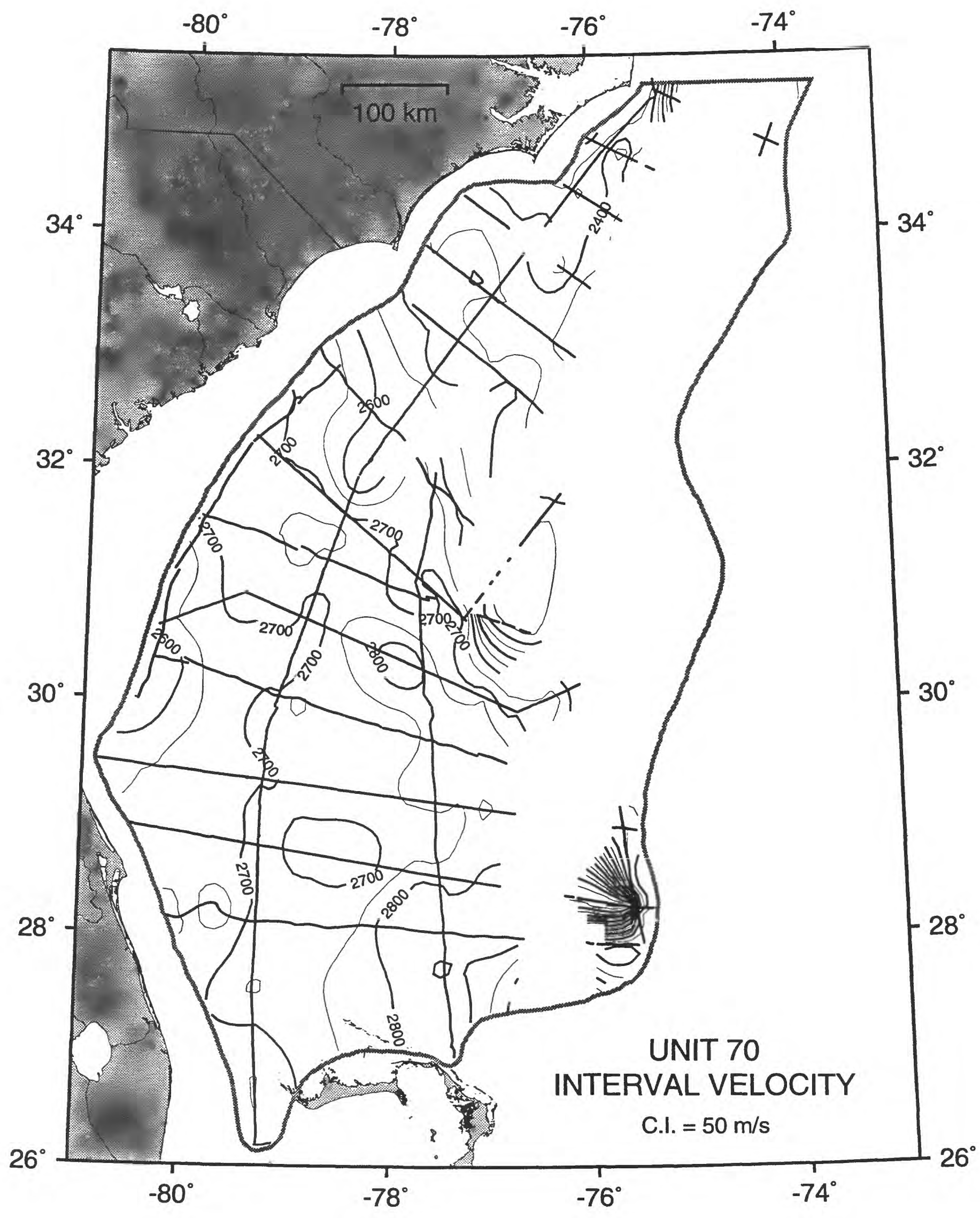




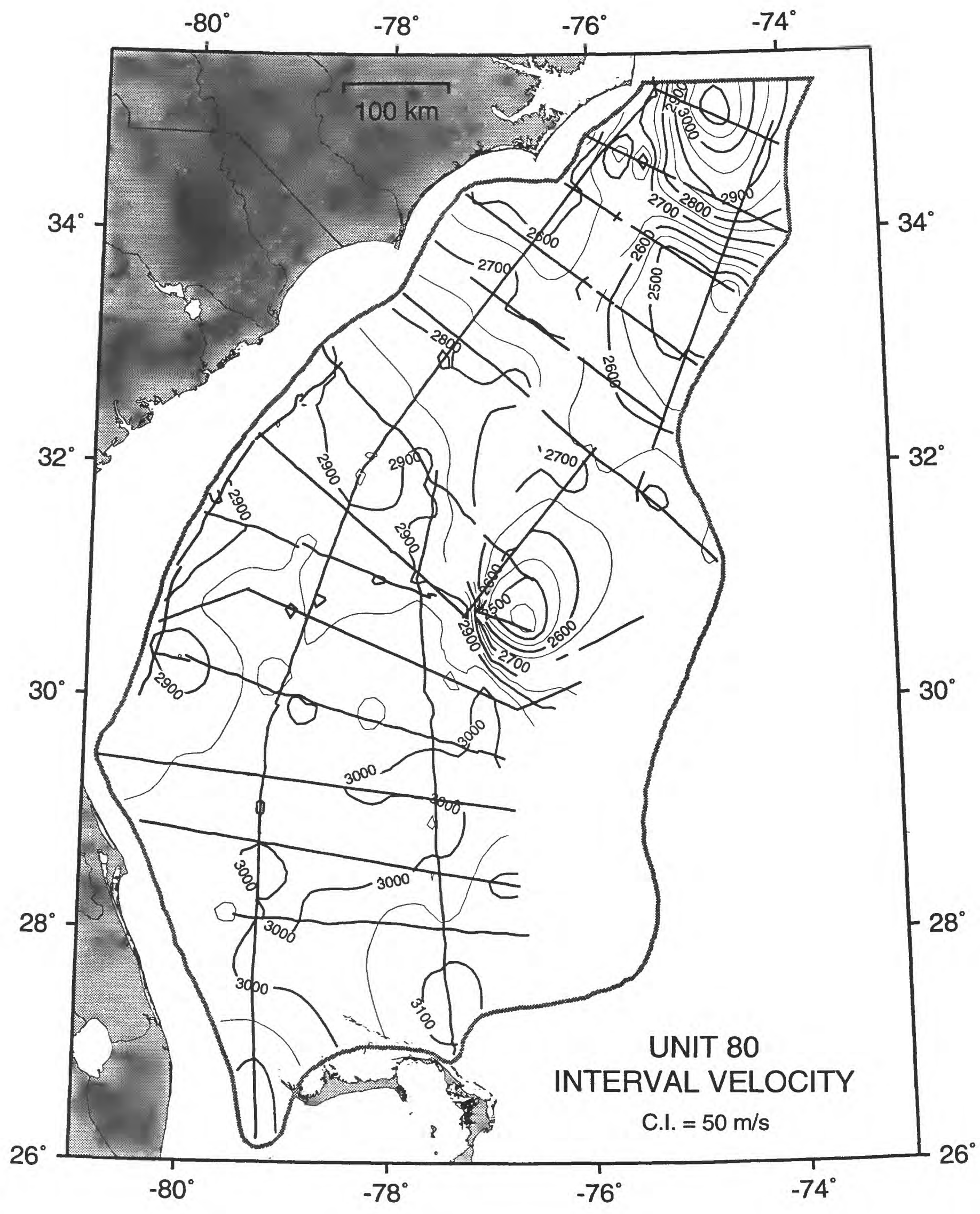




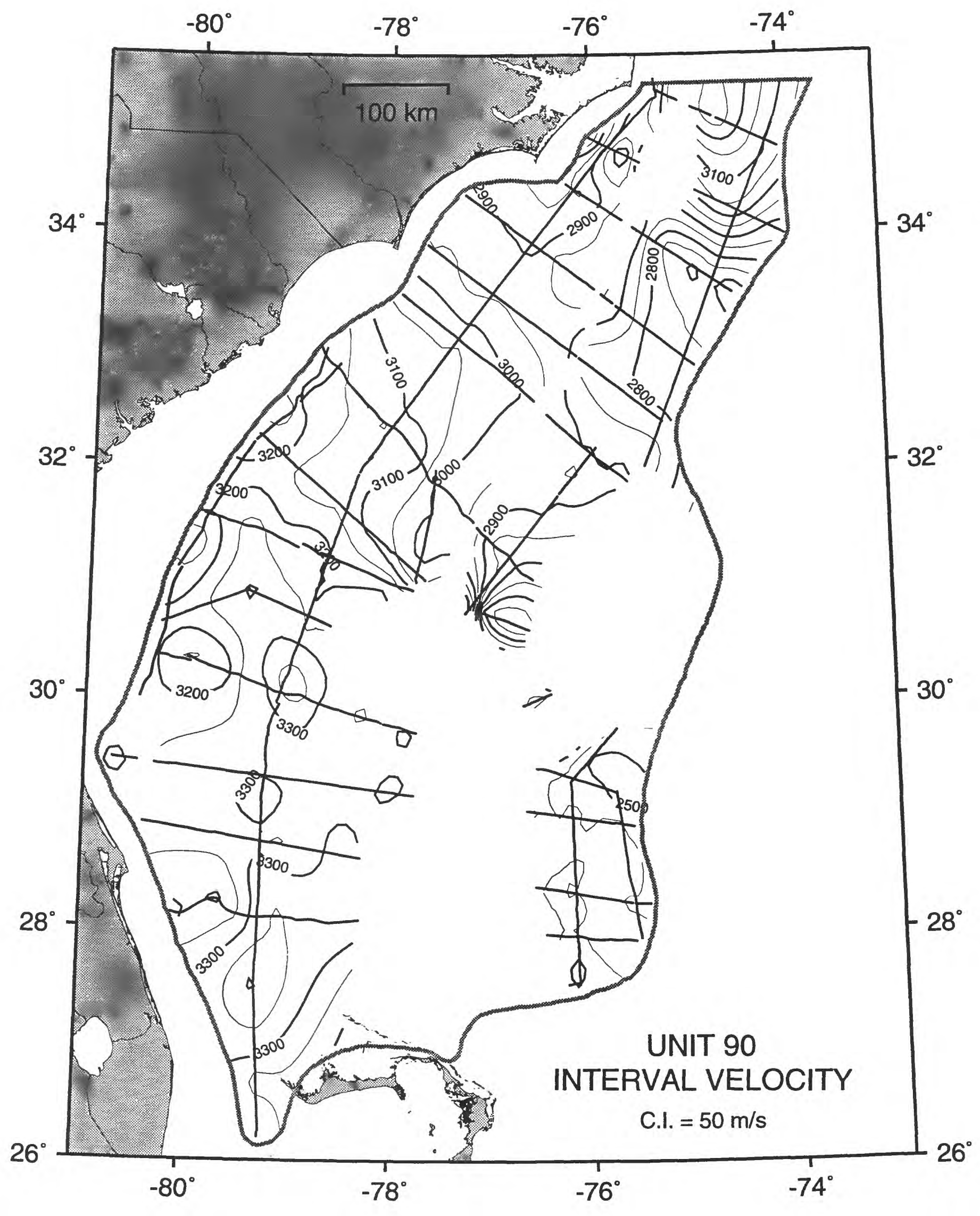




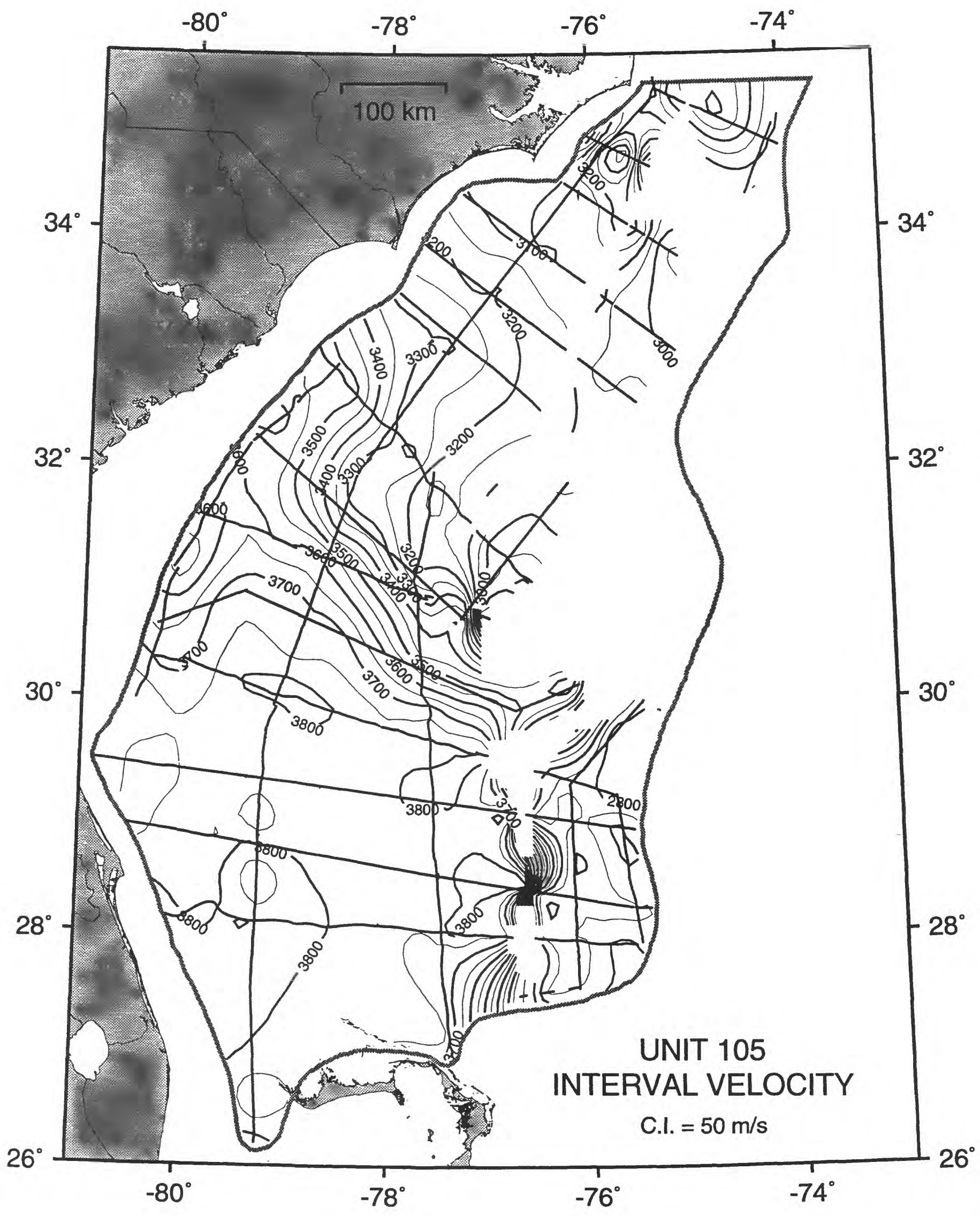




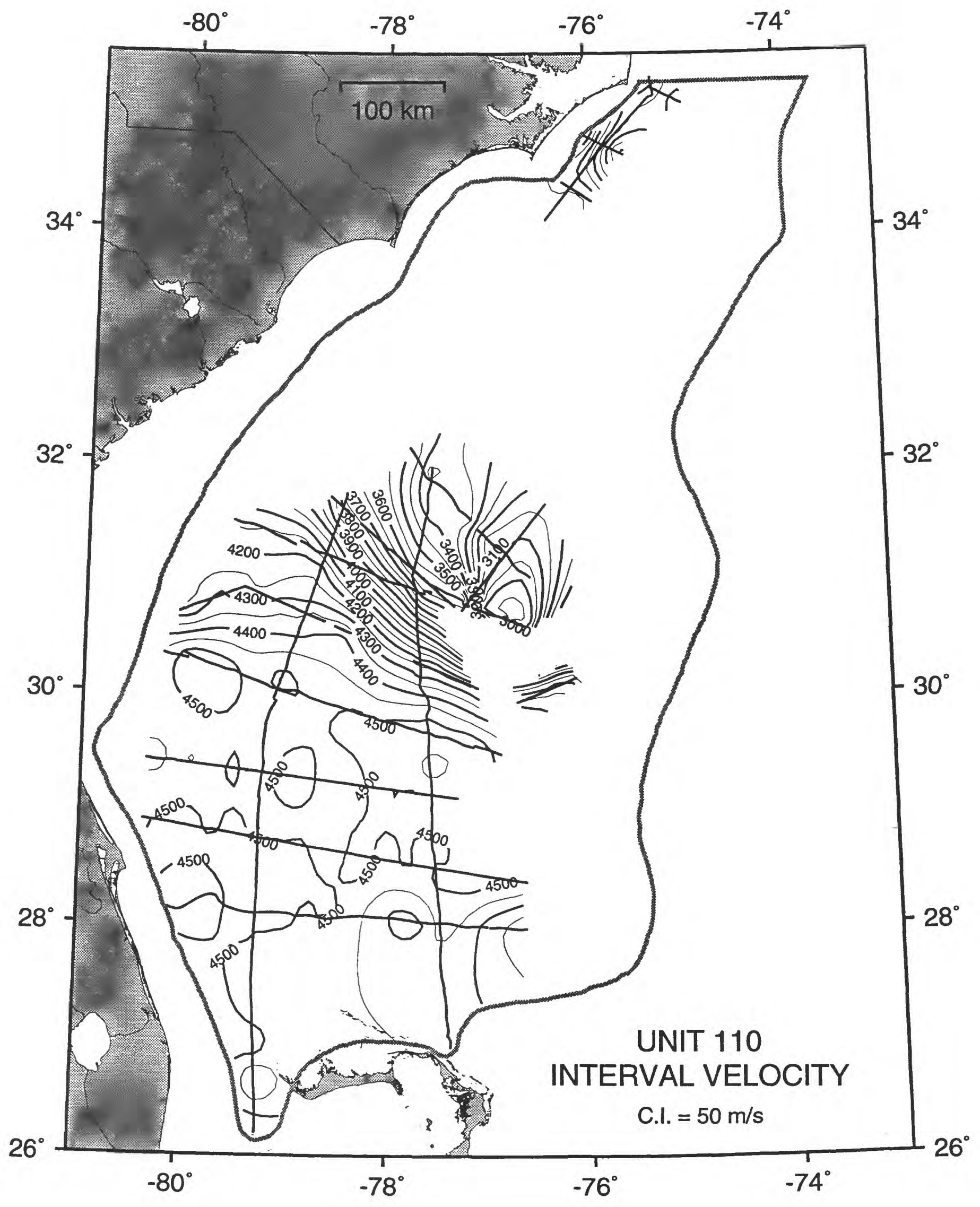




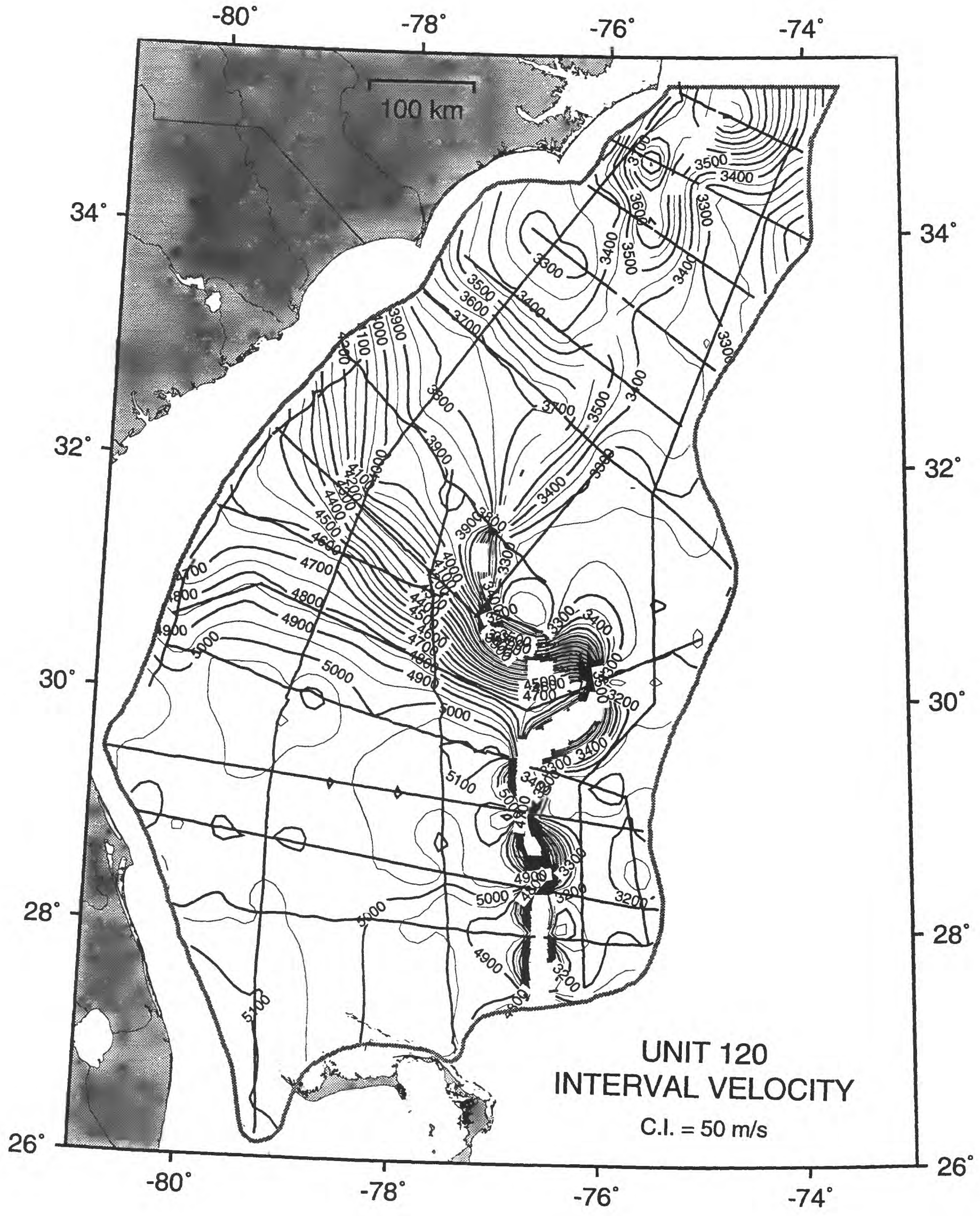




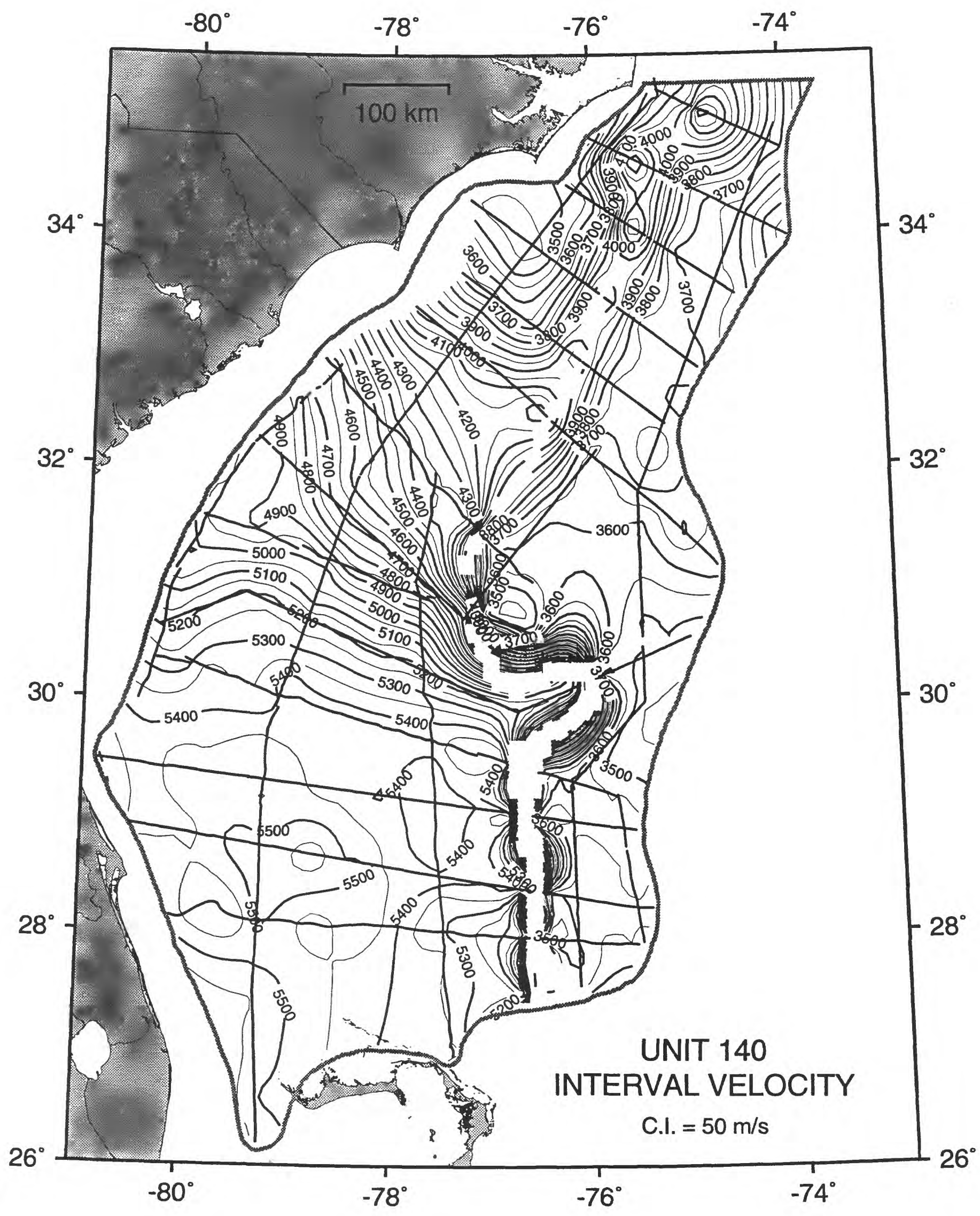




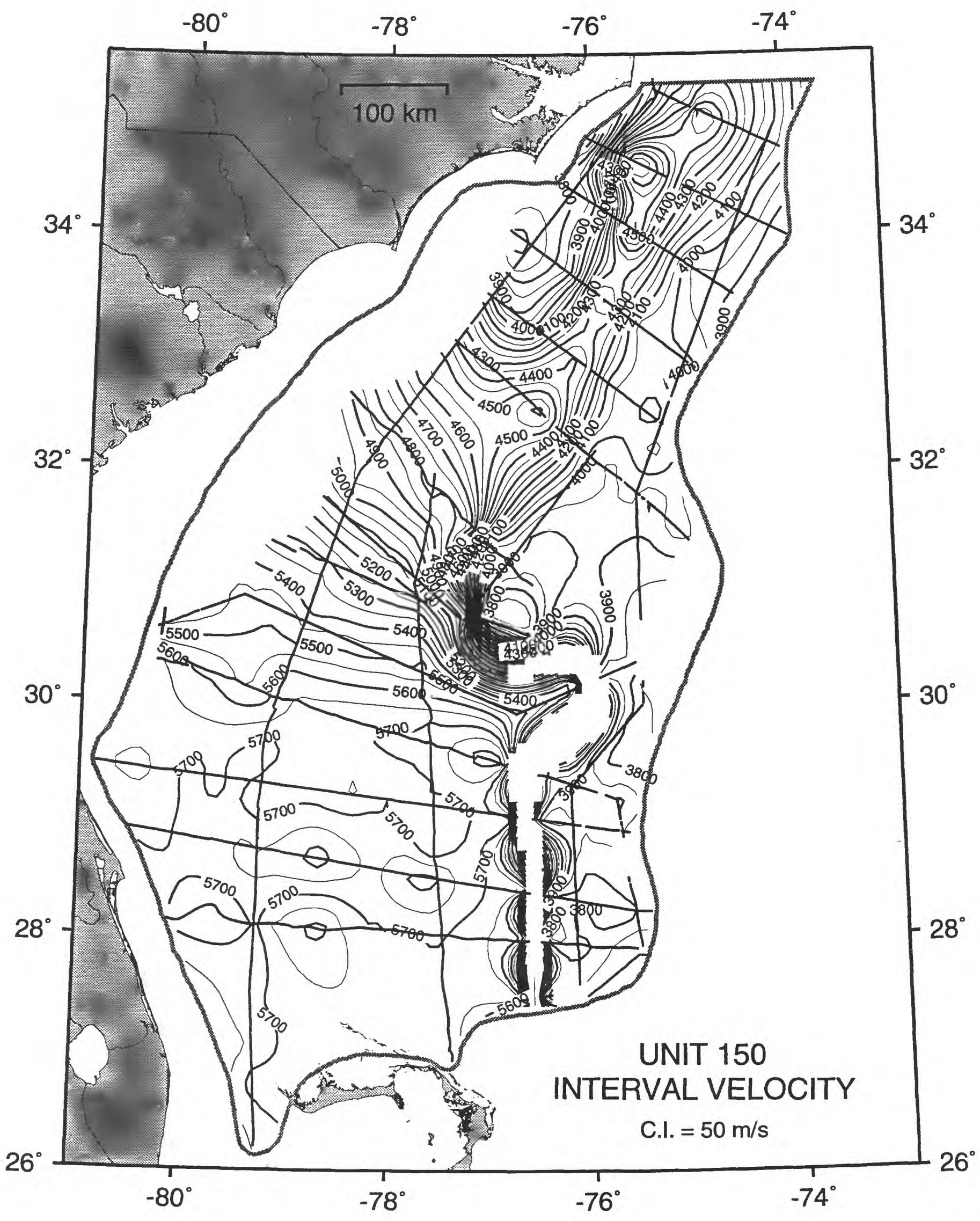




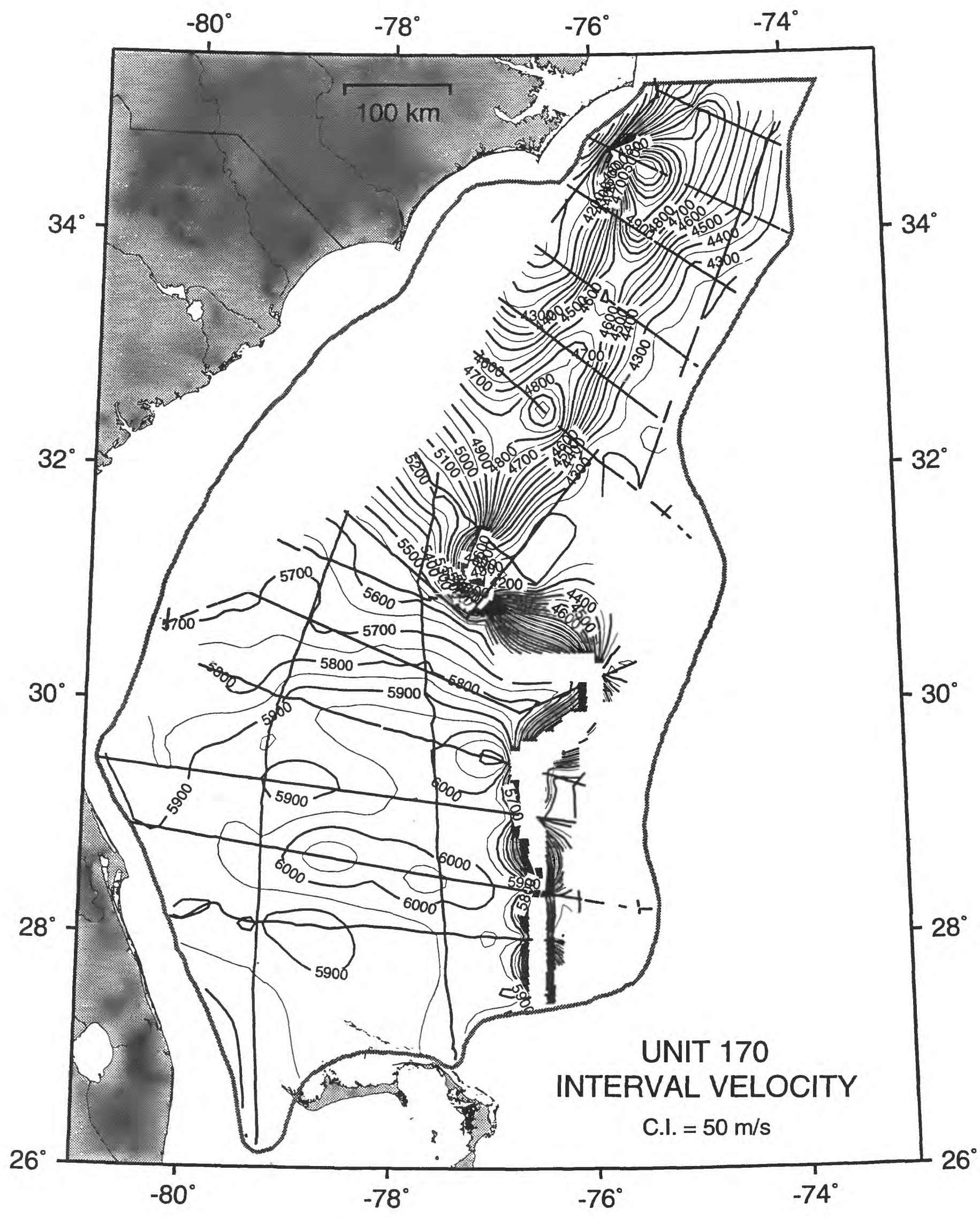




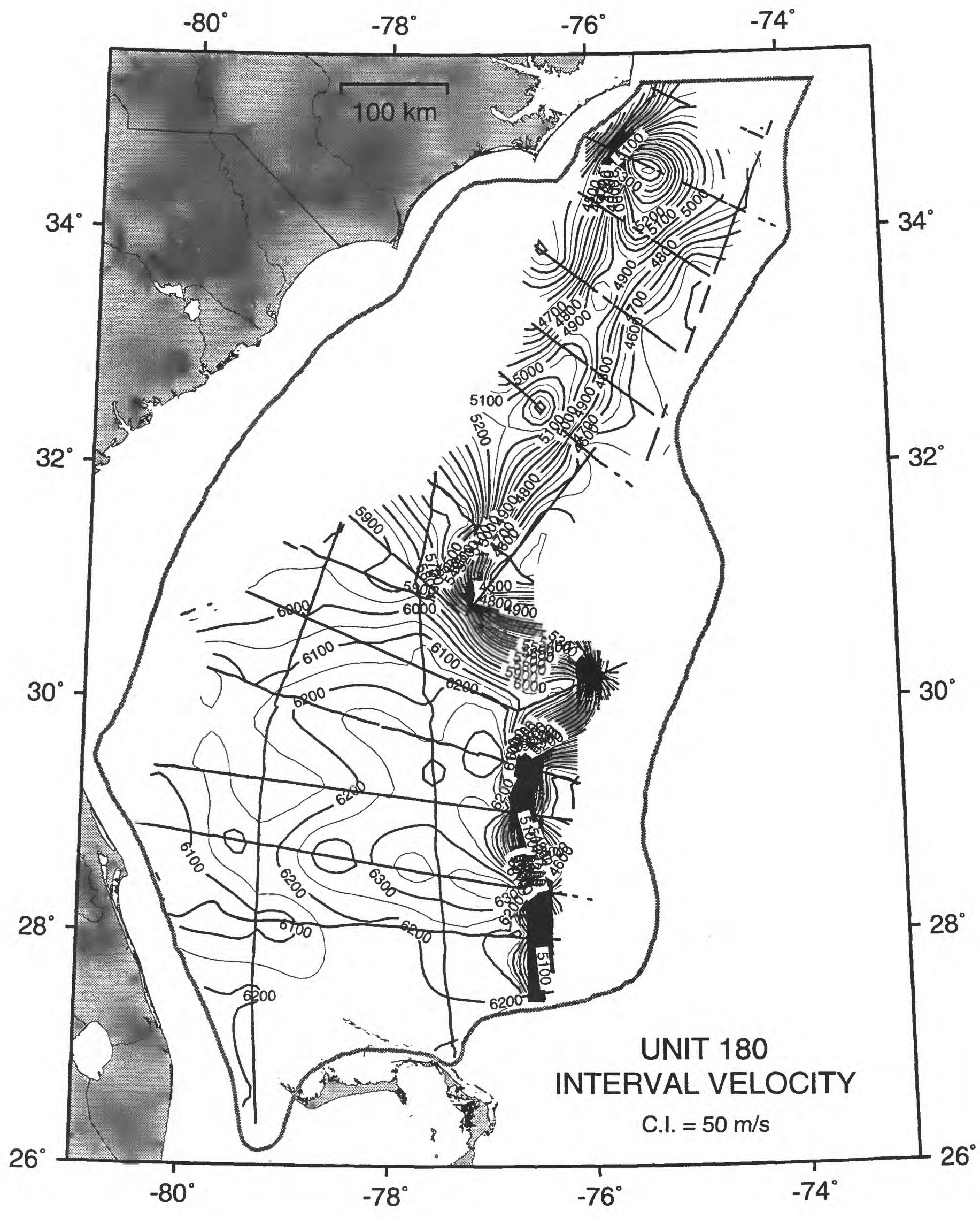




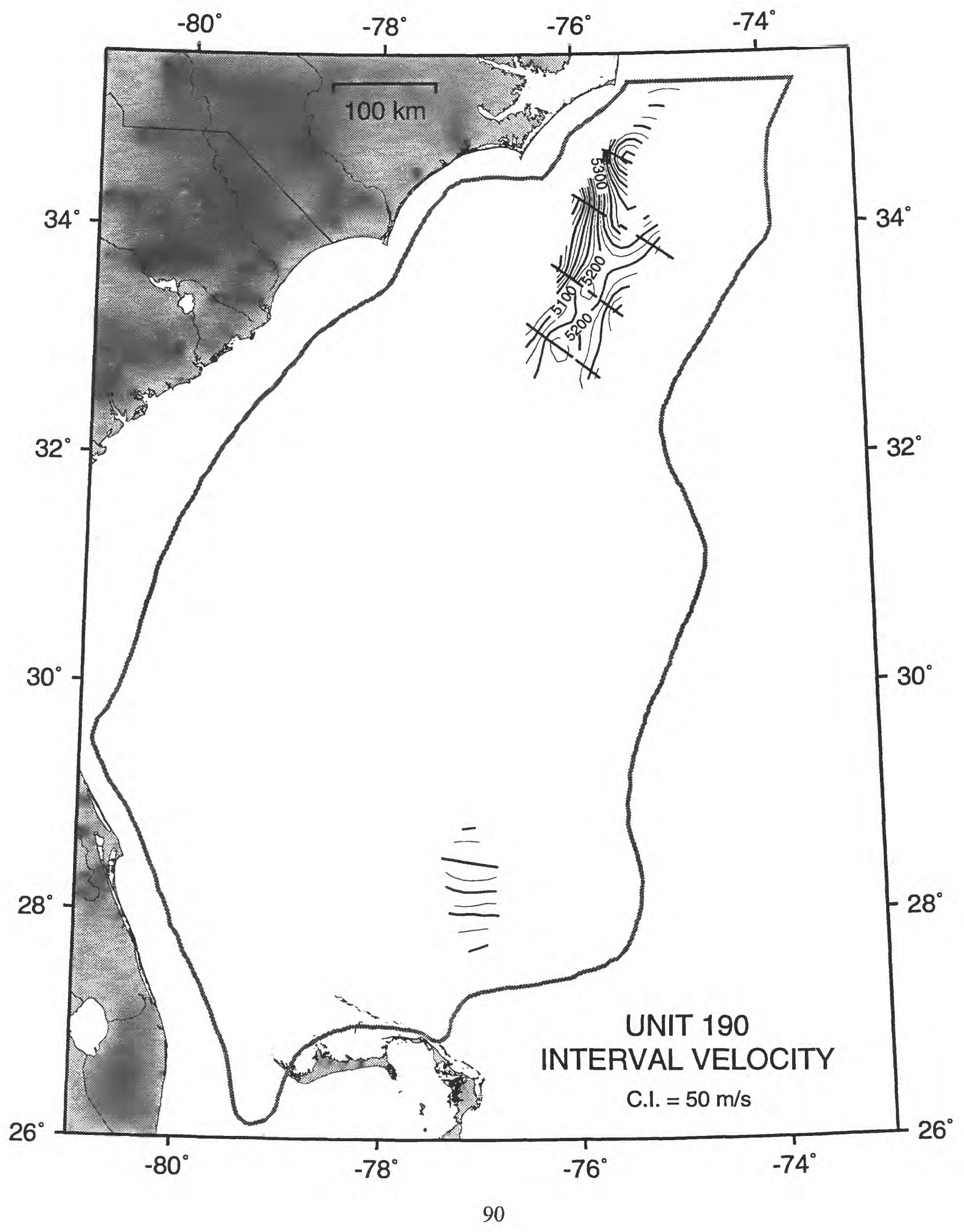




\section{APPENDIX 3}

\section{Gridded Data - Thickness Maps}

Maps showing the thicknesses of acoustic units $20-190$ are shown in this appendix. Tracklines showing seismic control are plotted with a heavy black line. Regions of no contours are outlined by a gray line and represent locations where the unit is absent. Grid nodes within these blank regions are set to zero. Contour interval is $50 \mathrm{~m}$. 


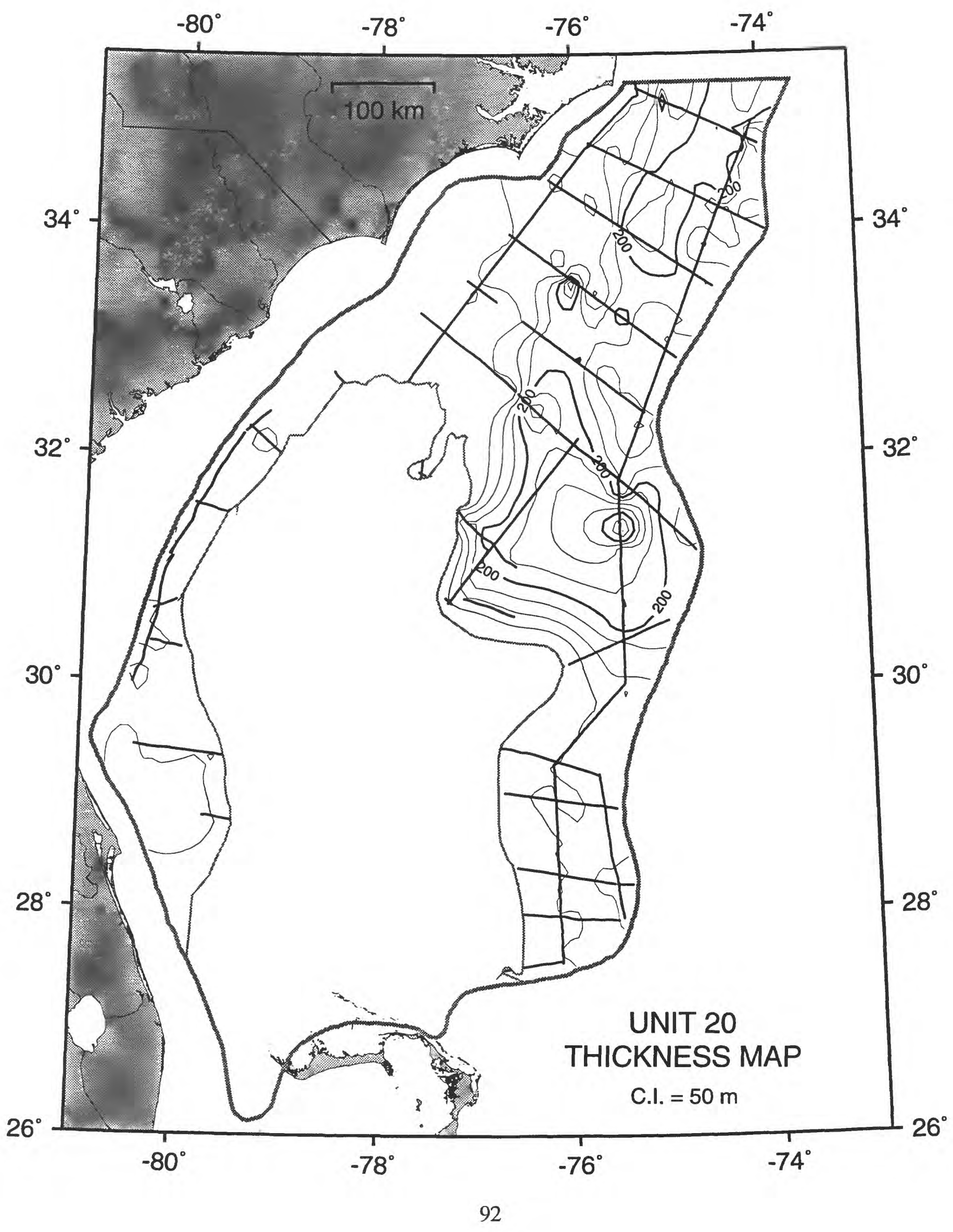




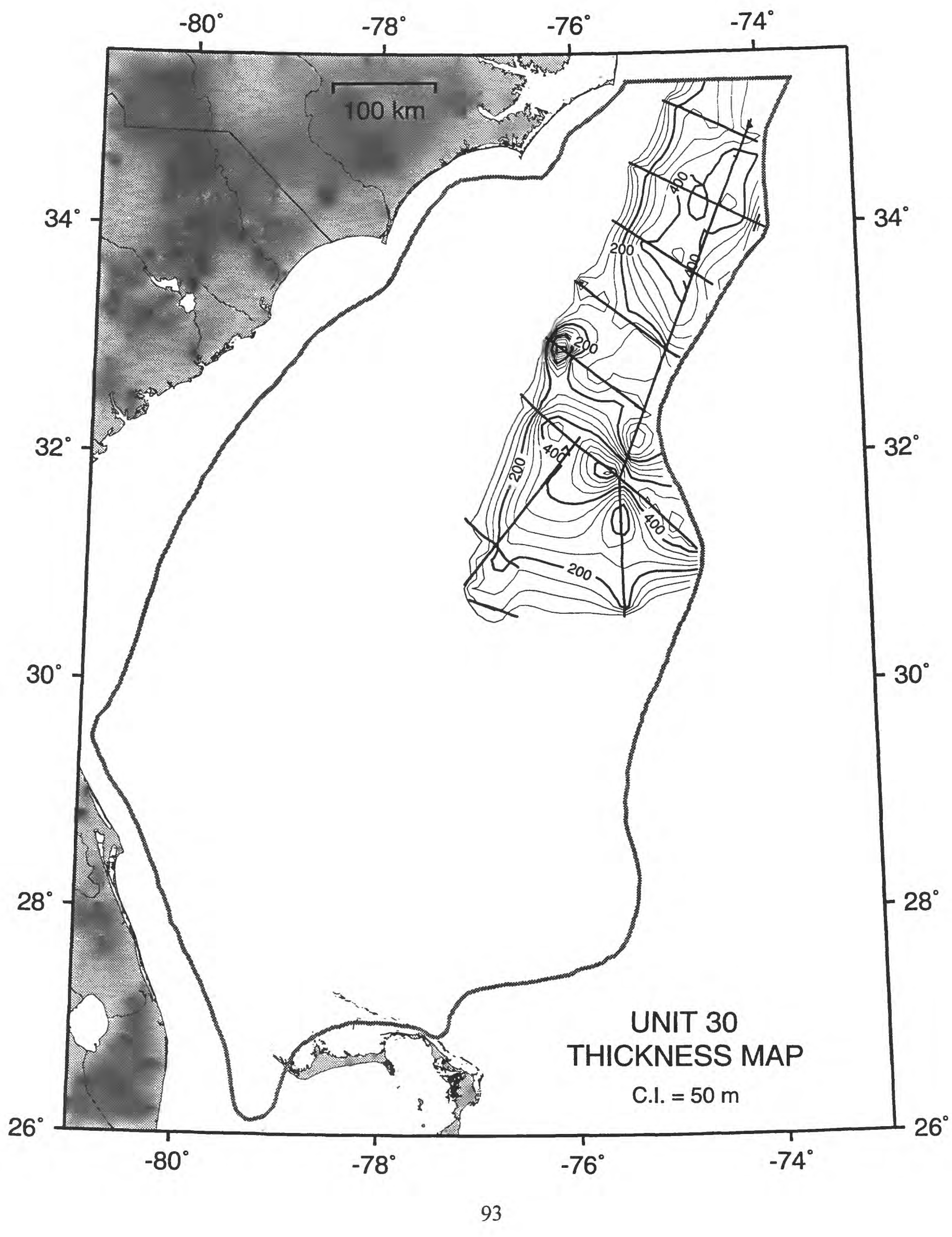




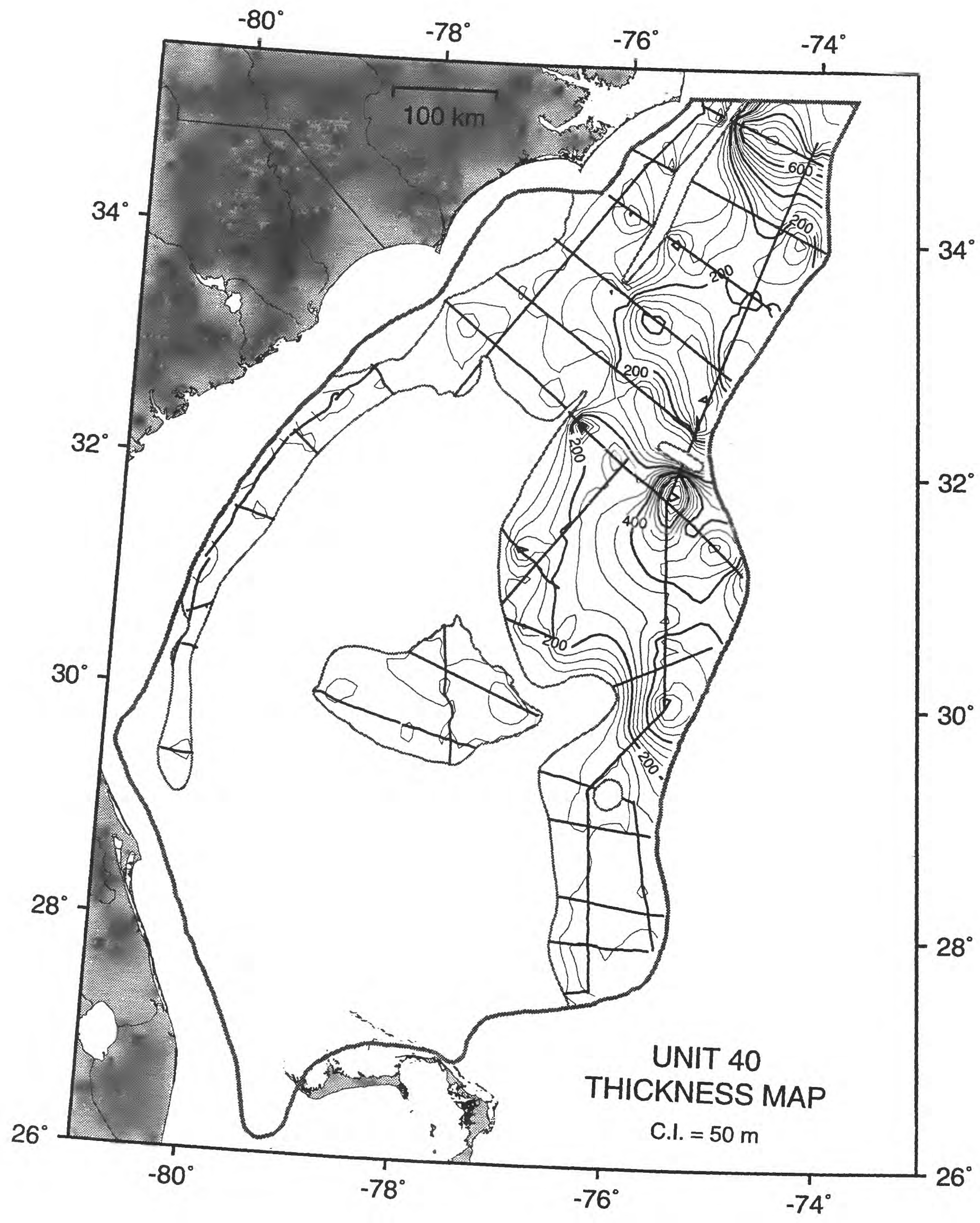




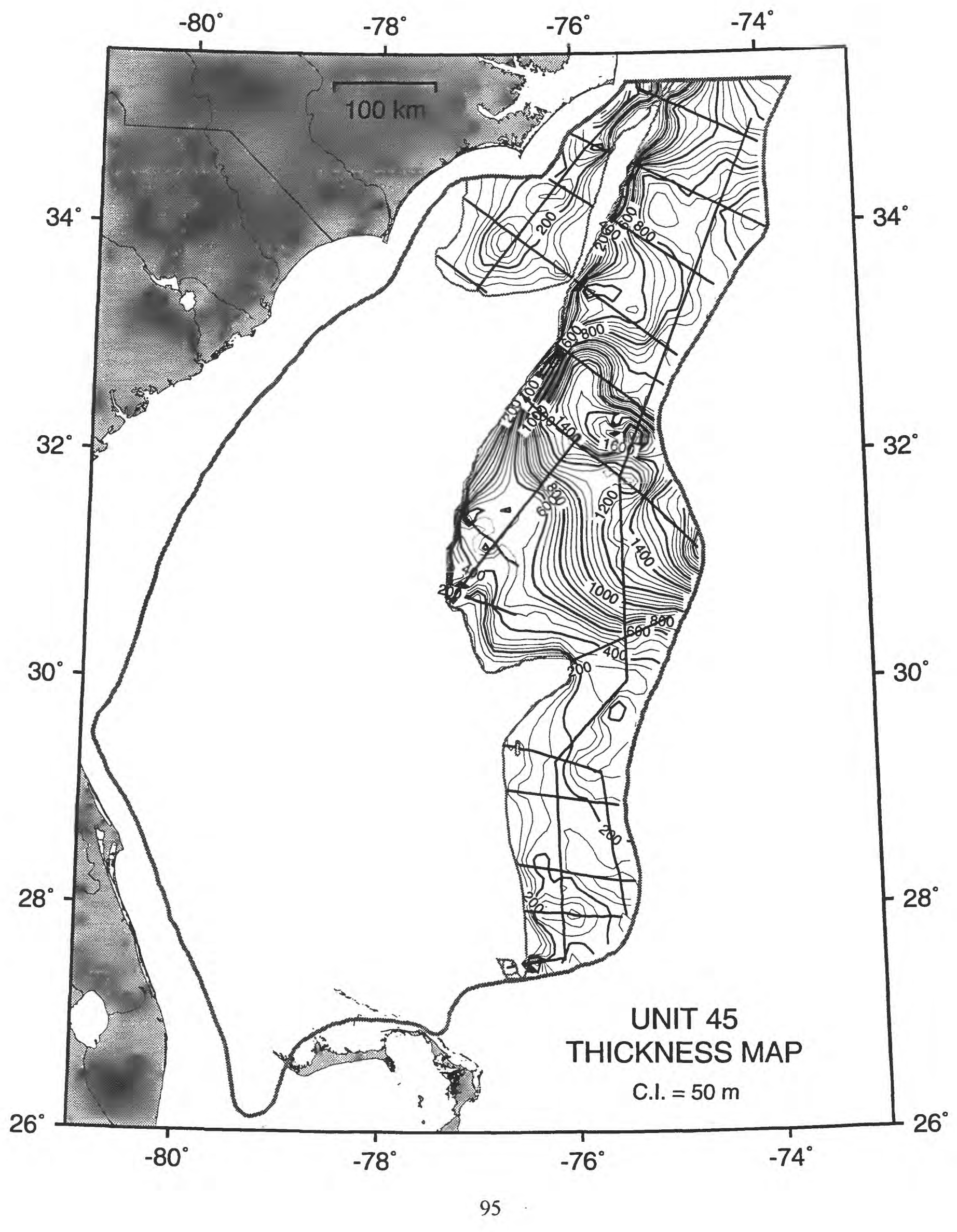




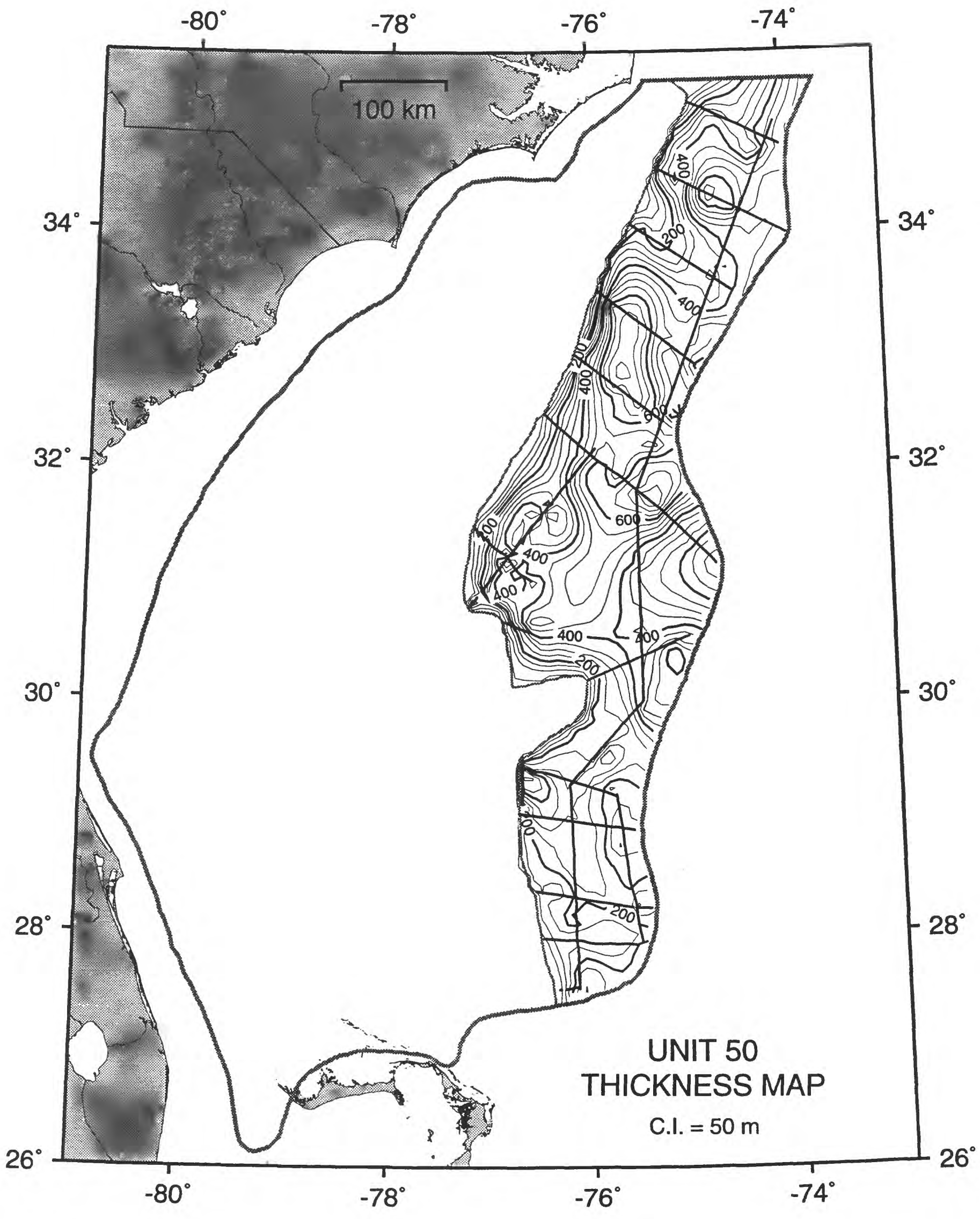




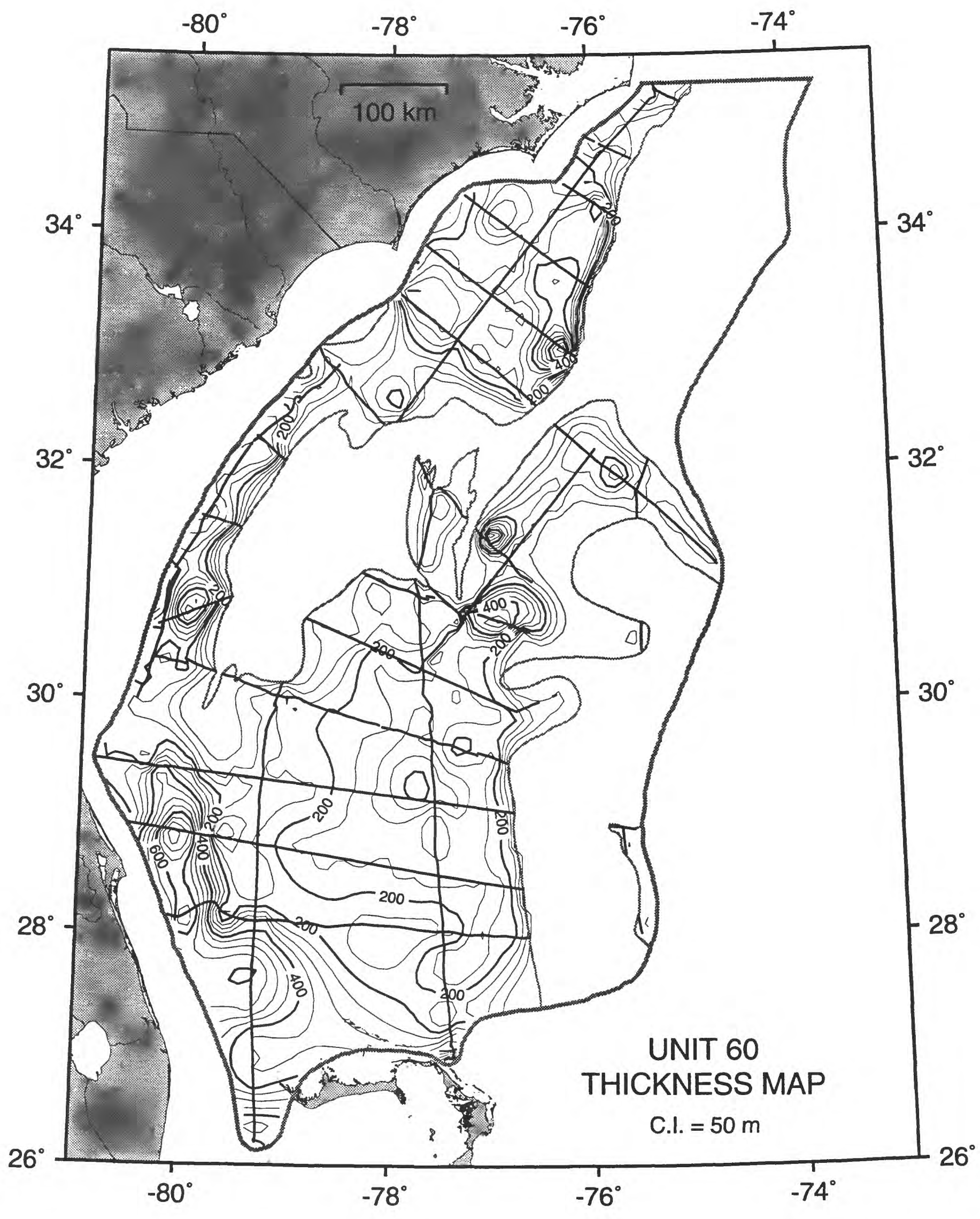




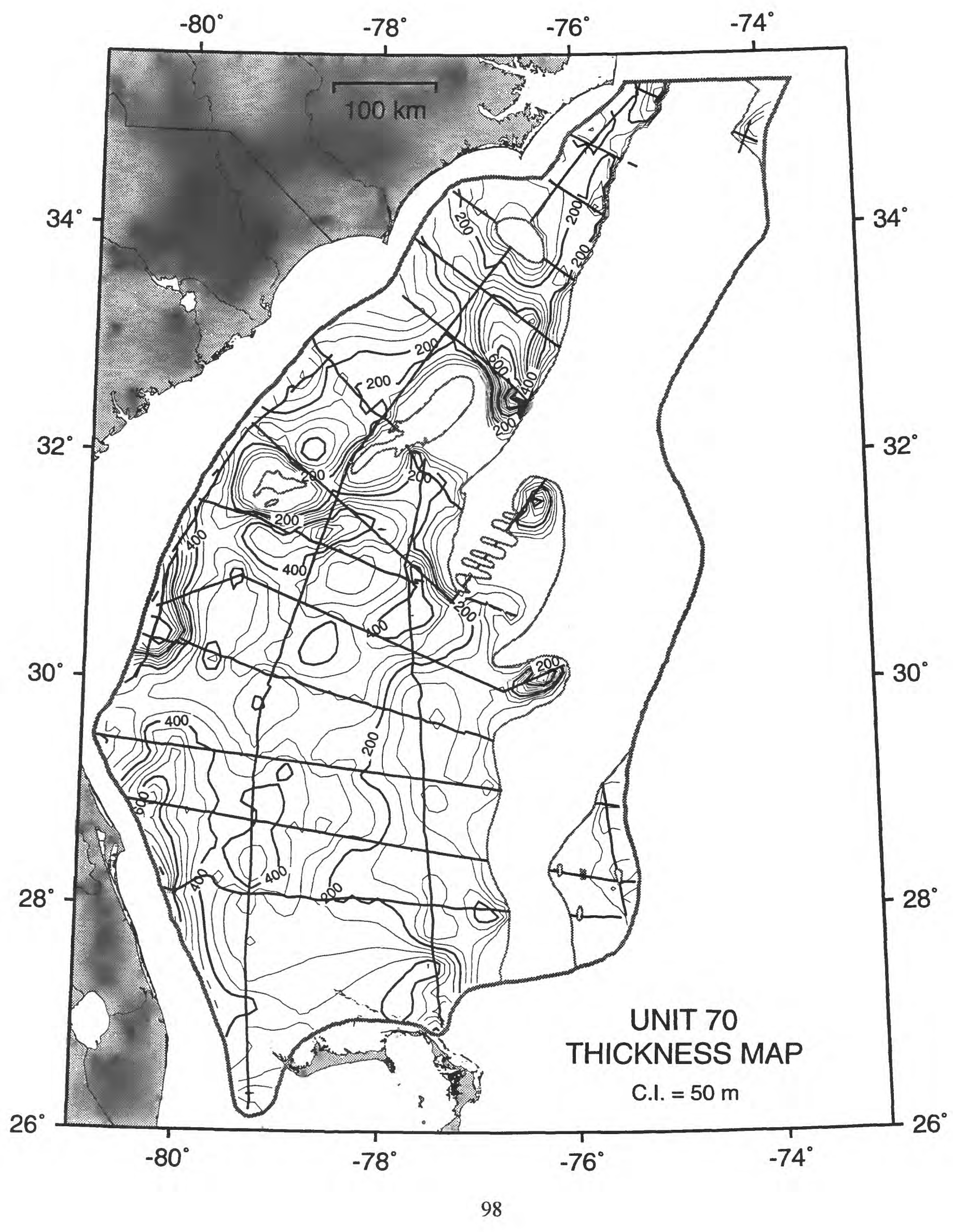




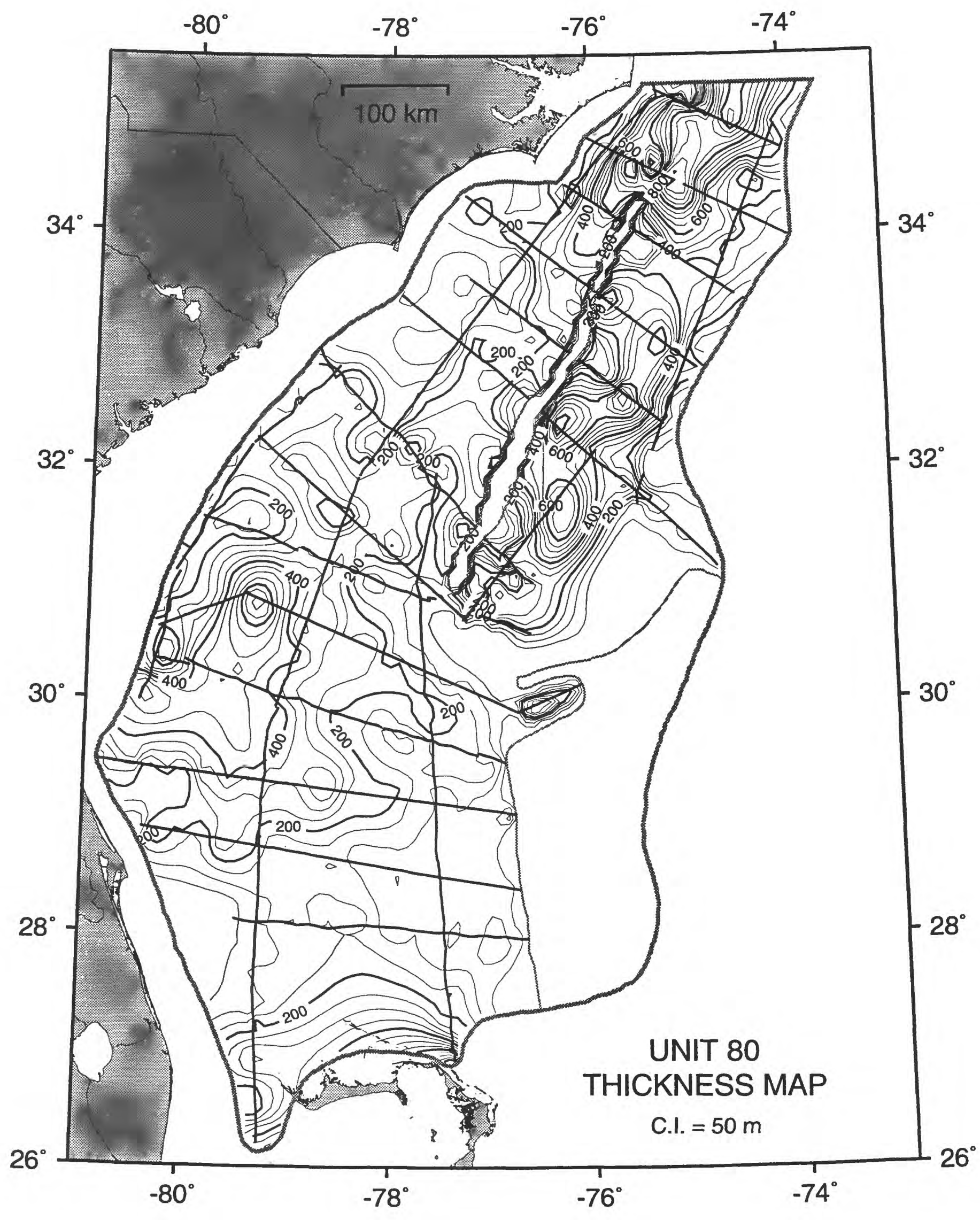




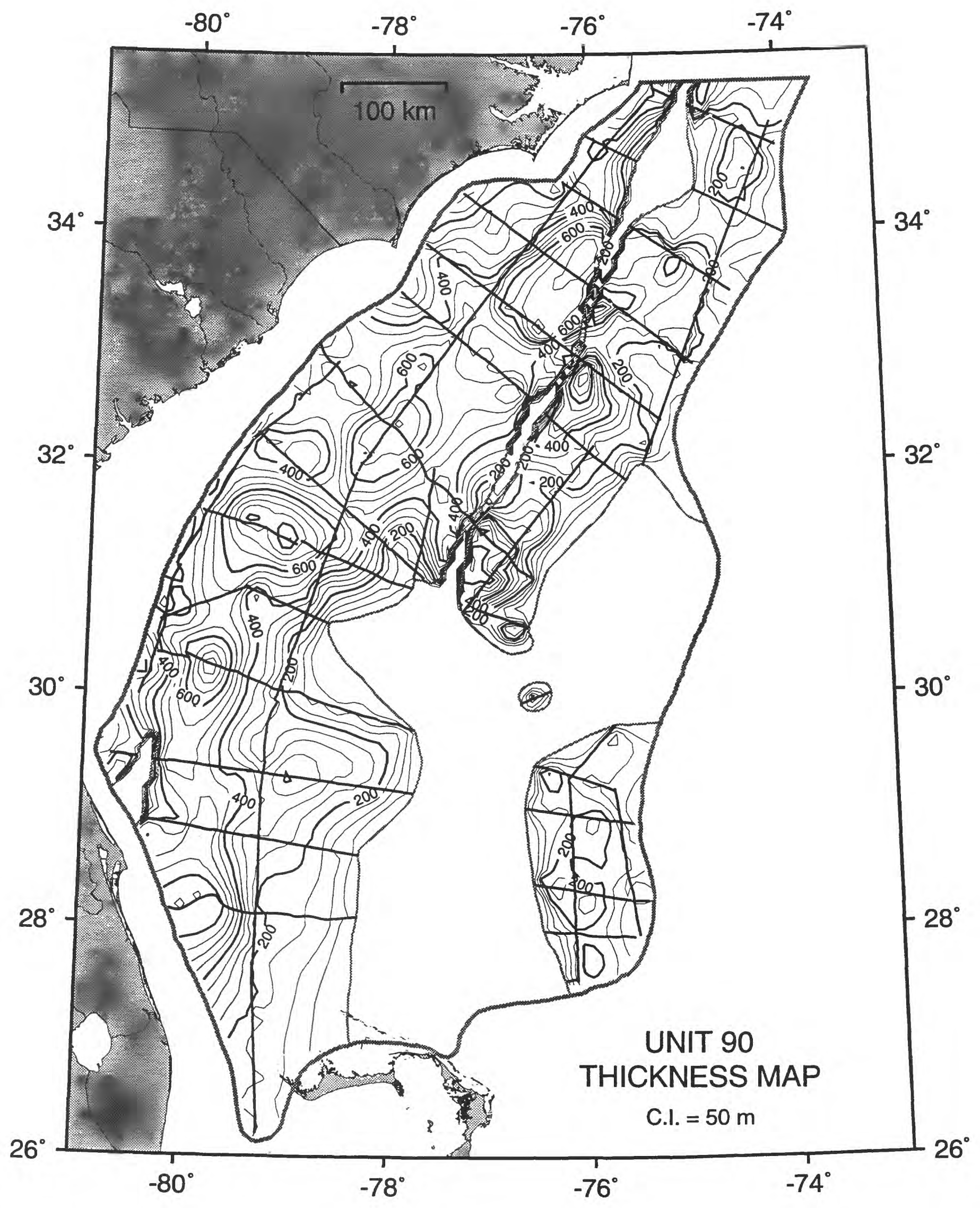




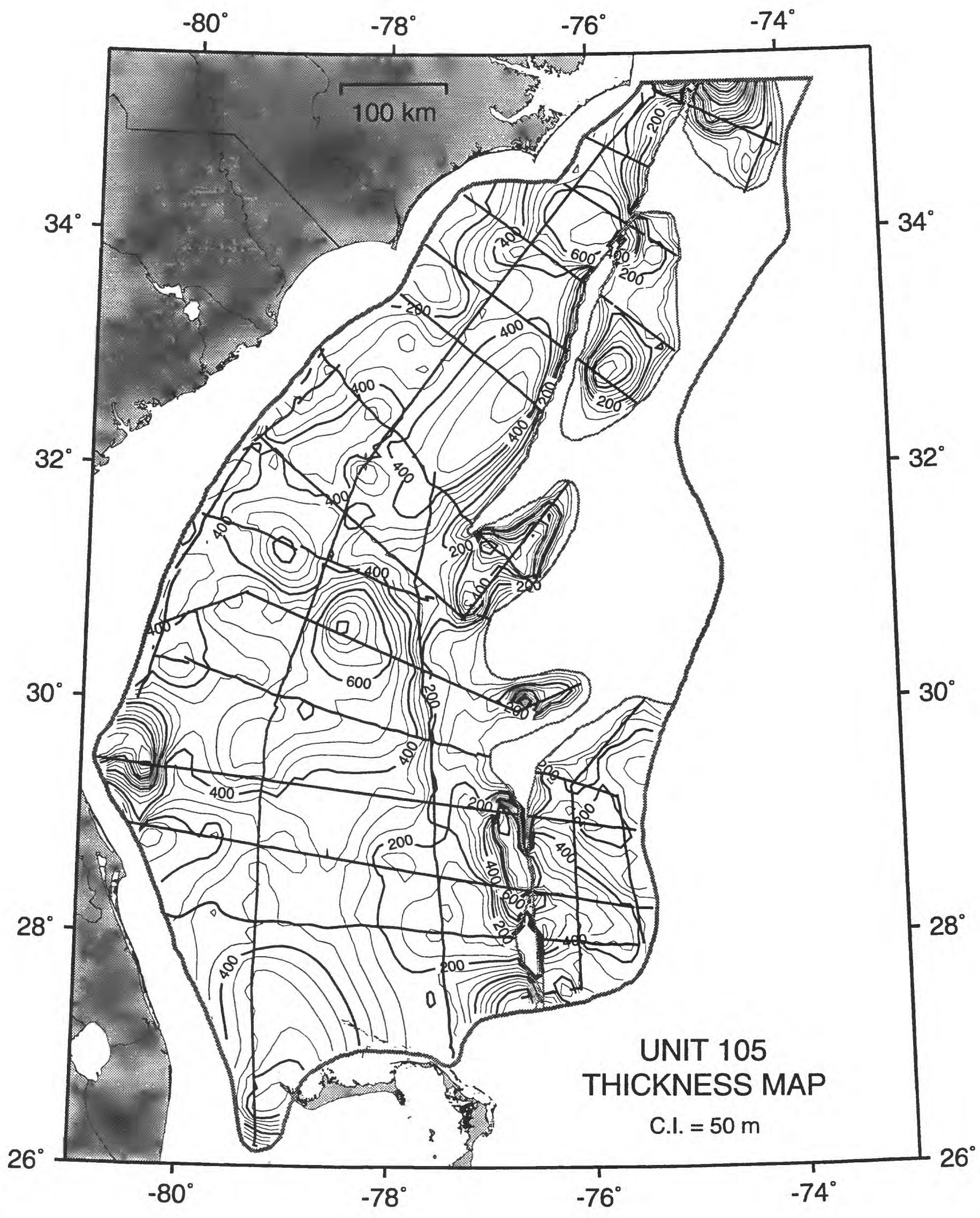




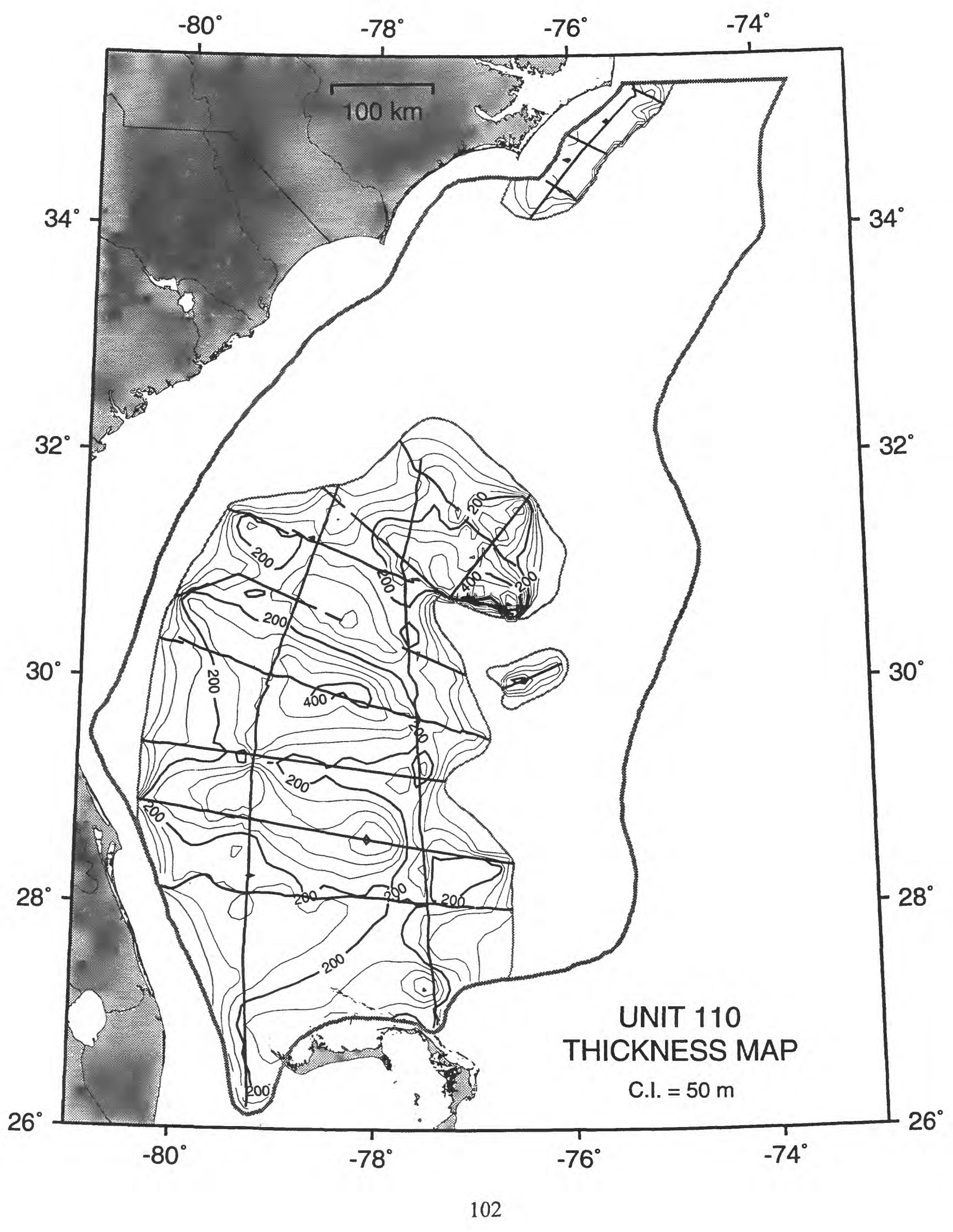




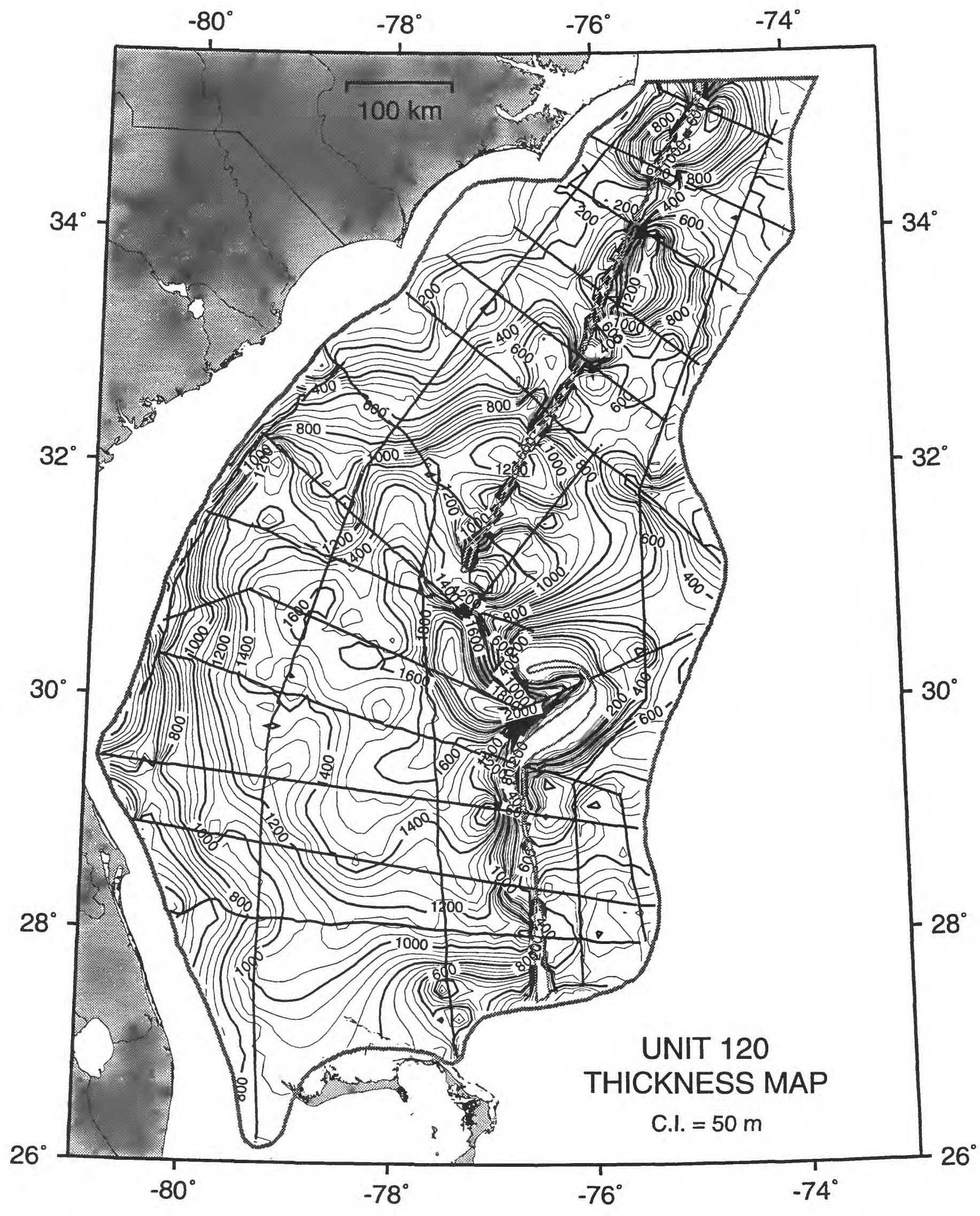




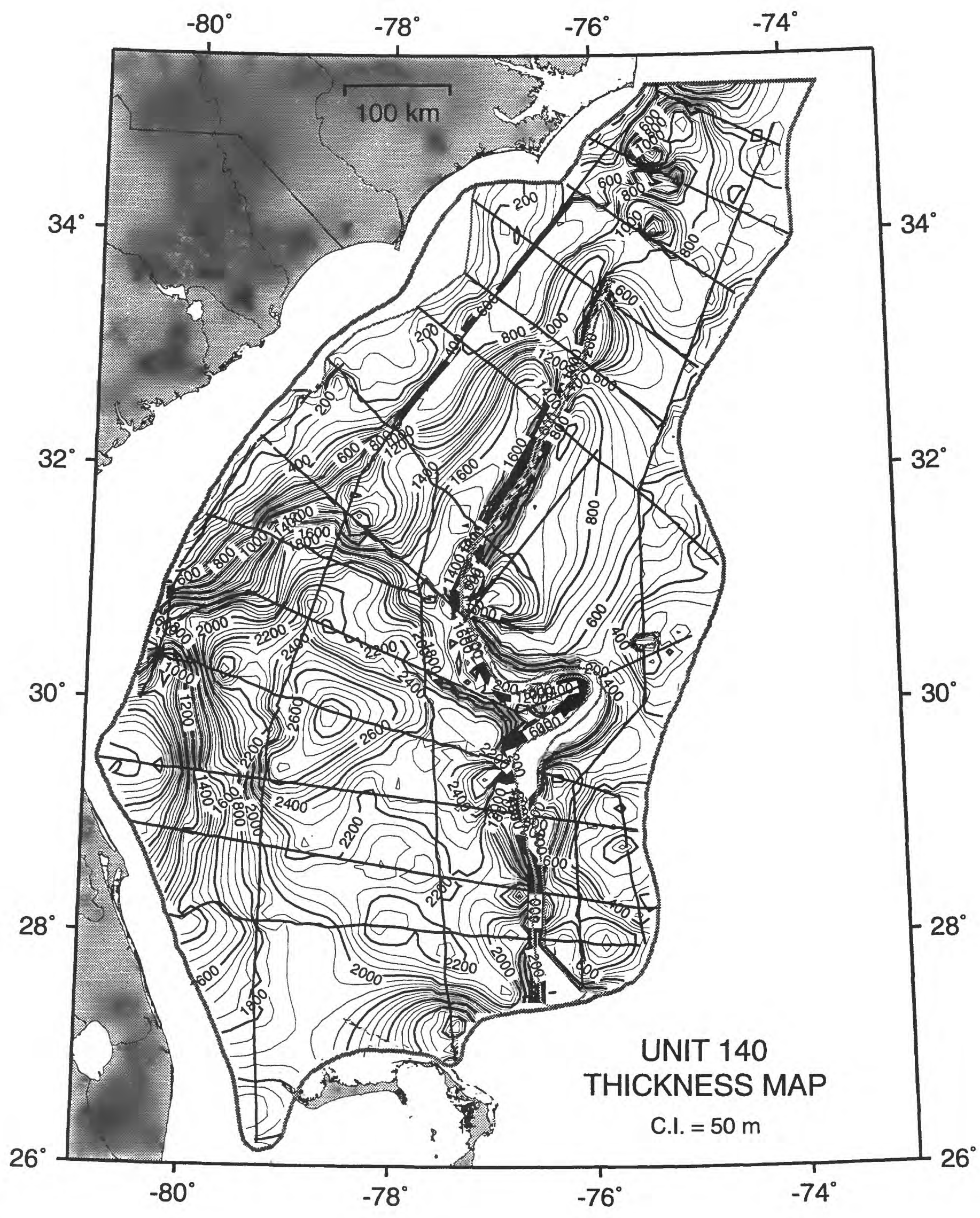




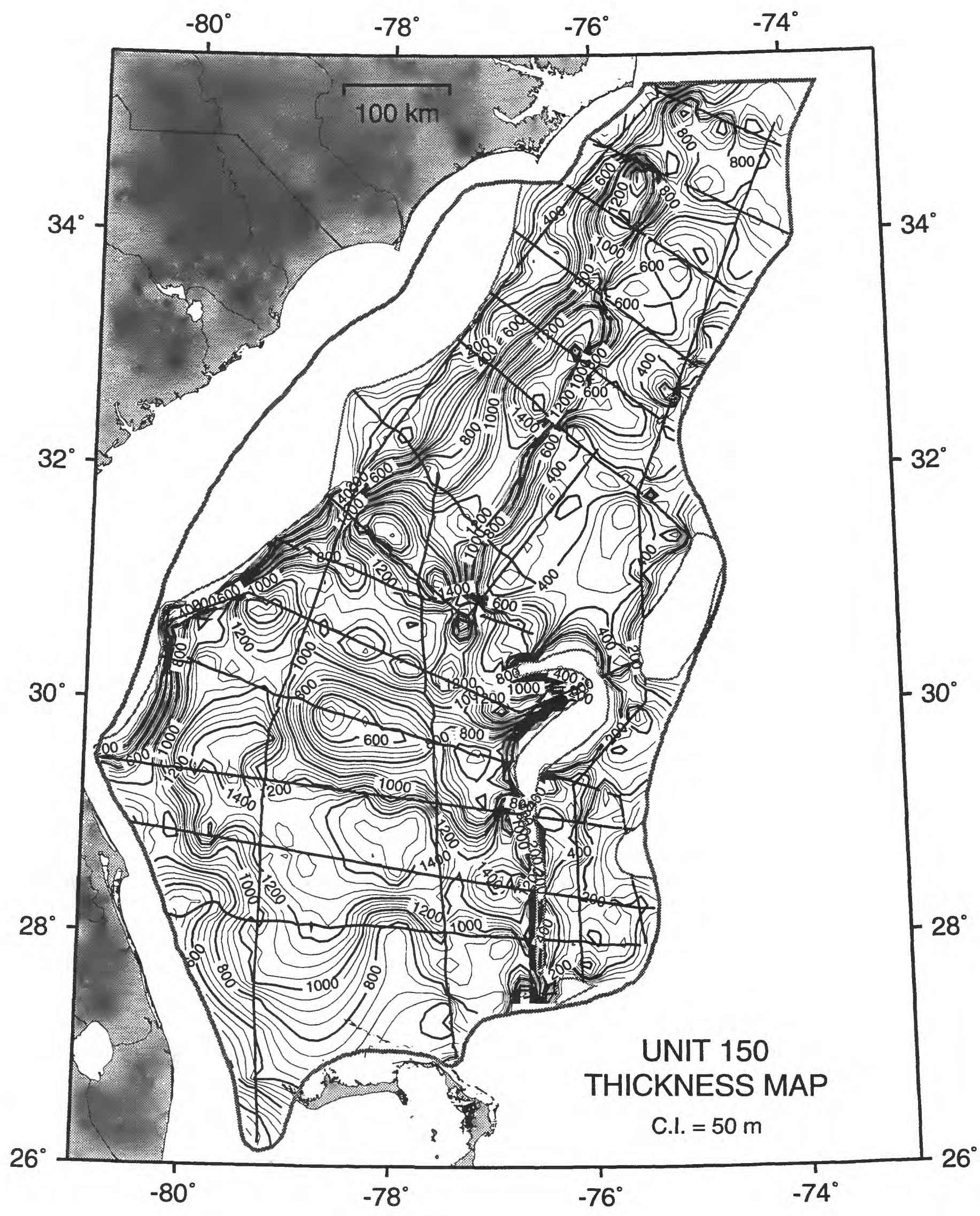




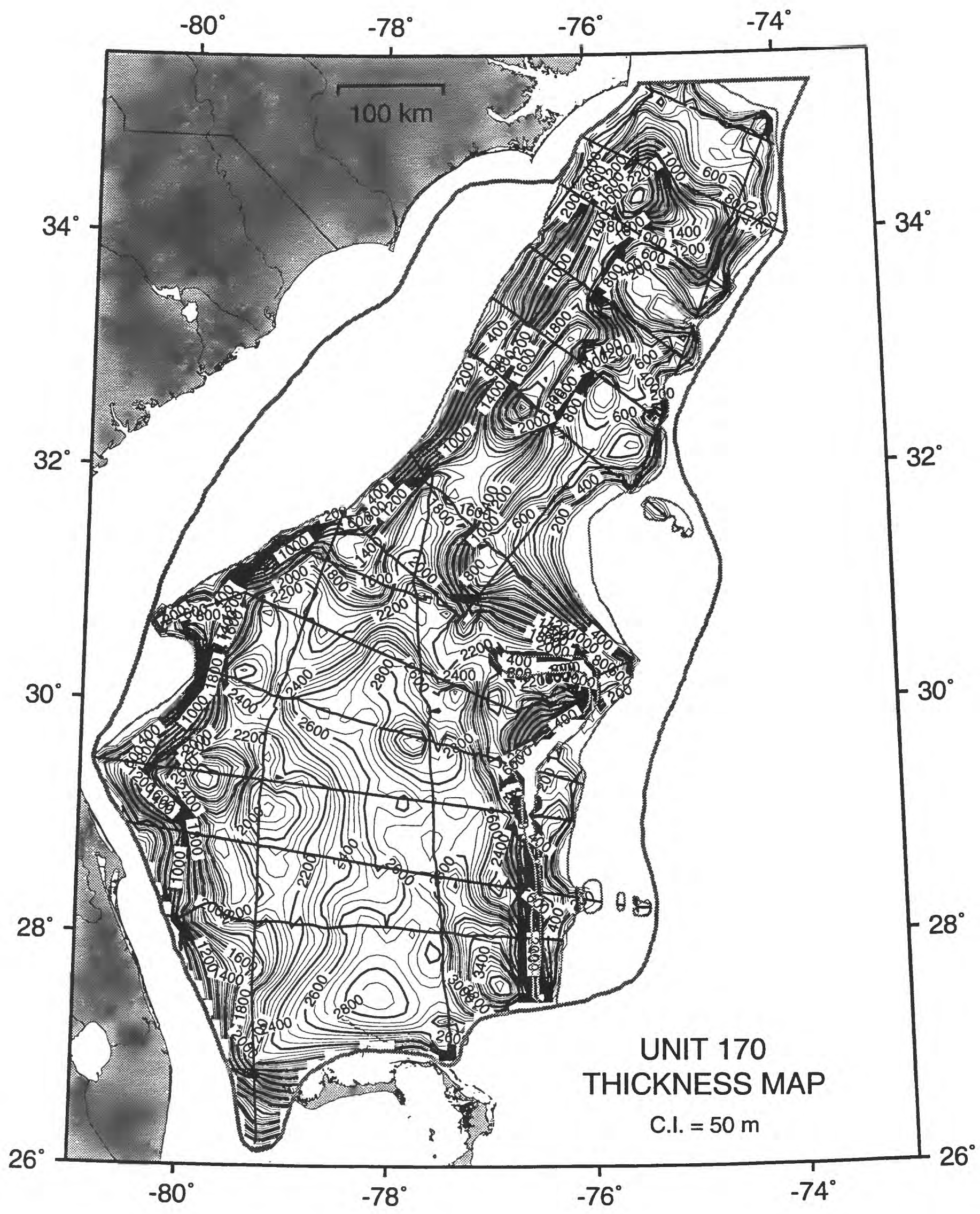




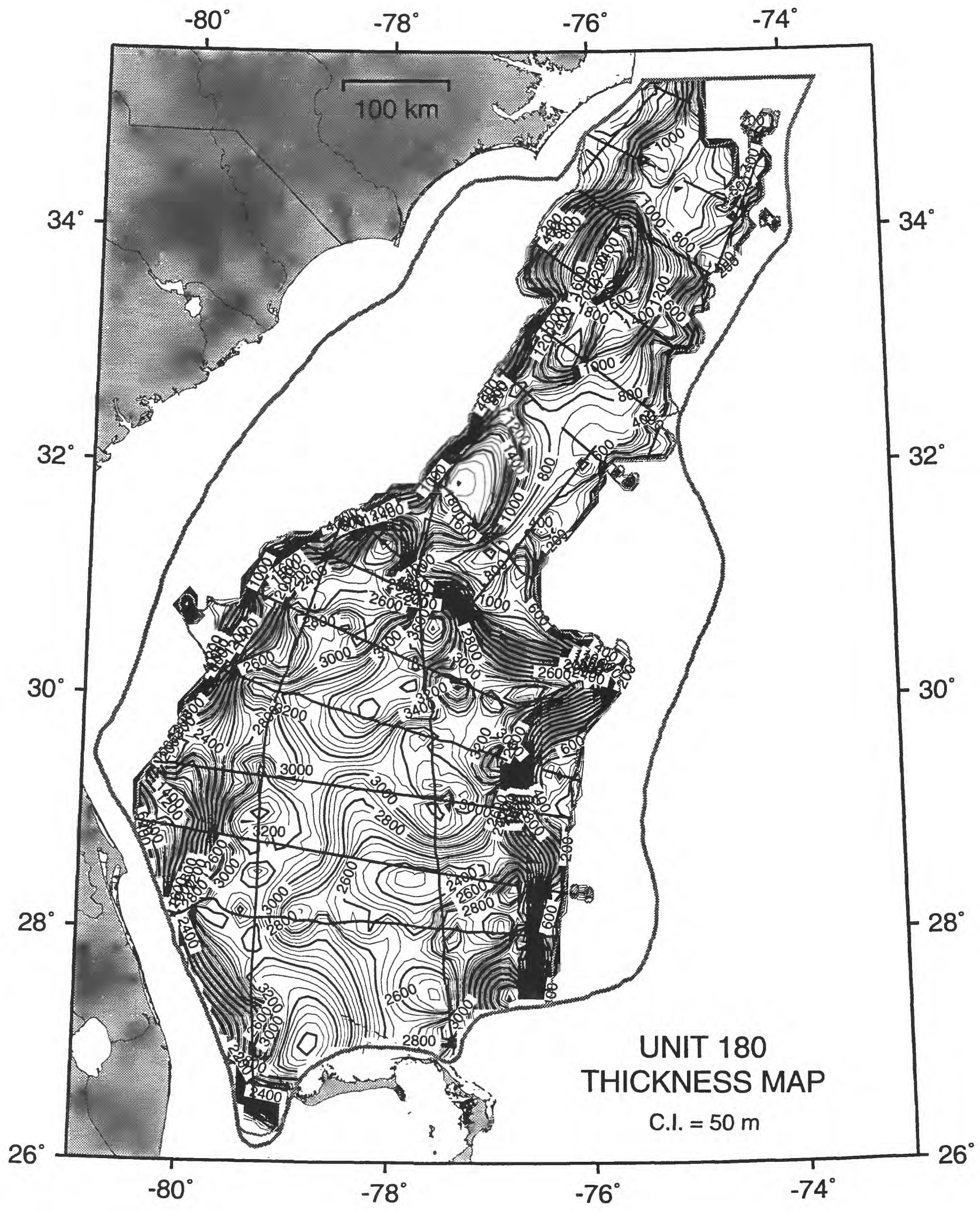




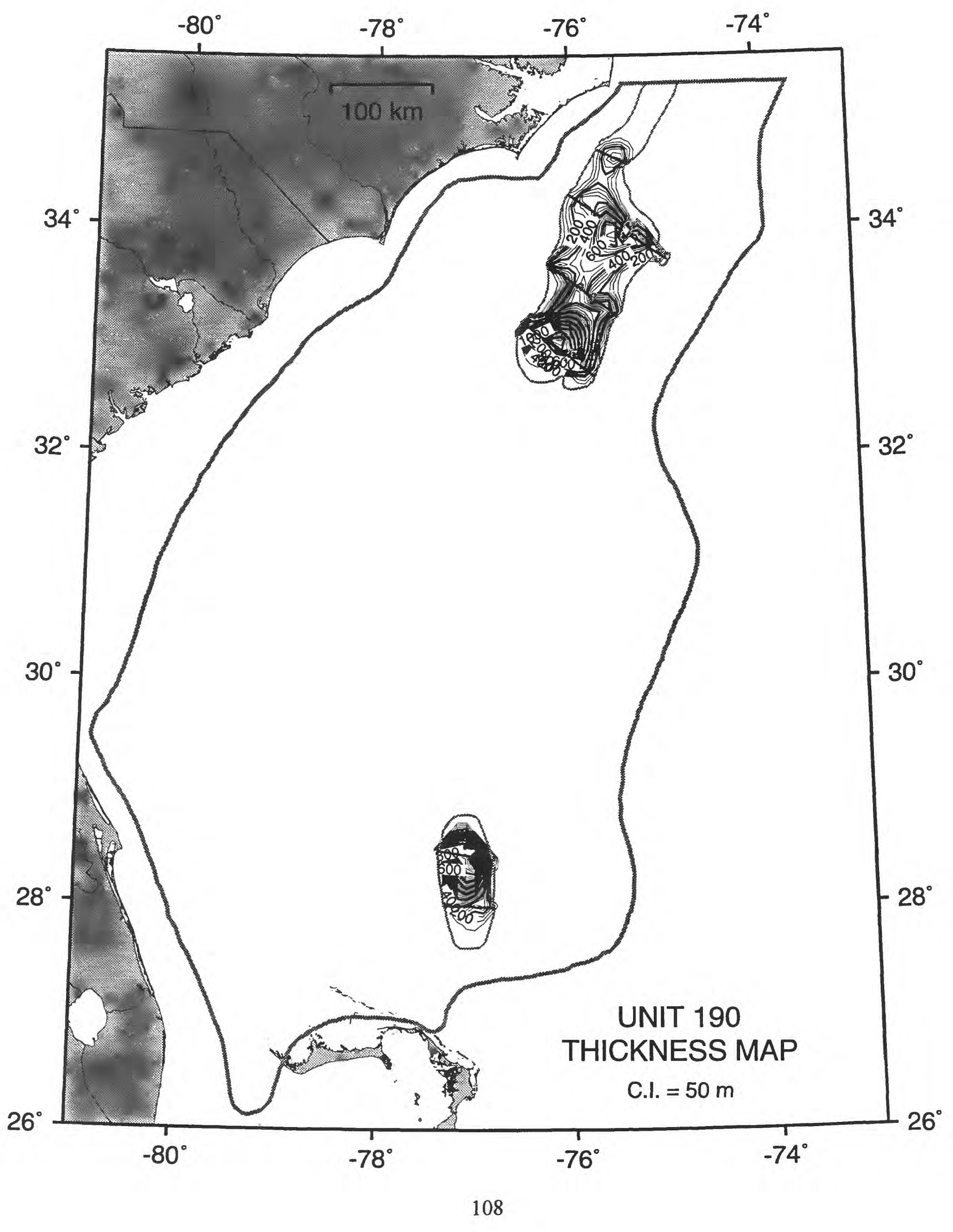




\section{APPENDIX 4}

\section{Gridded Data - Structure Maps in Time}

This appendix gives contour maps of the two-way travel times to the base of each acoustic unit in this data base. The heavy black lines represent locations of seismic profiles used to generate the maps. Regions of no contours are outlined and indicate places where the surface is absent. Maps for reflectors 105 - 190 include stippling along the Carolina Slope and Blake Escarpment to show areas where artifacts in the gridding and contouring exist. Contour interval is .2 seconds. 


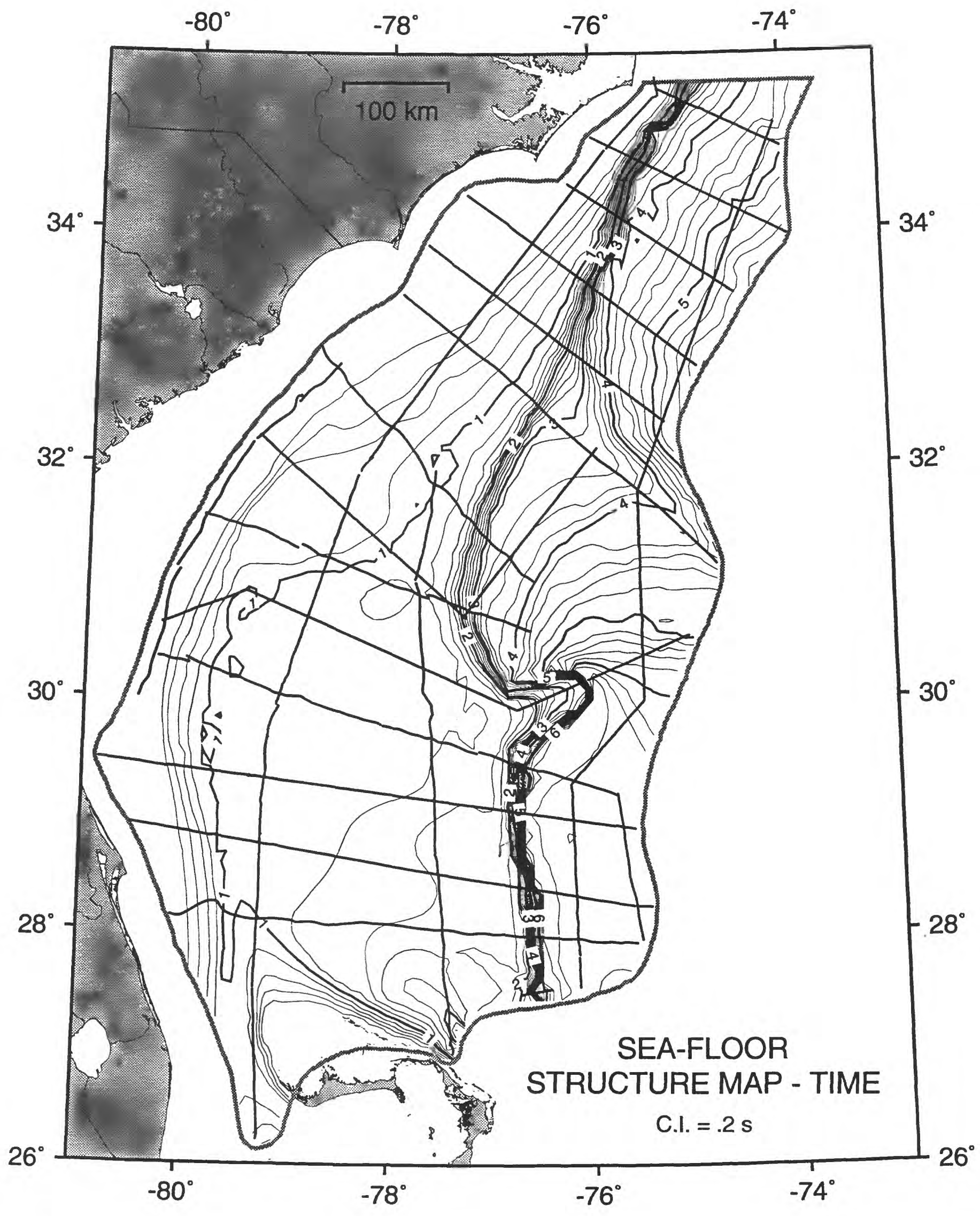




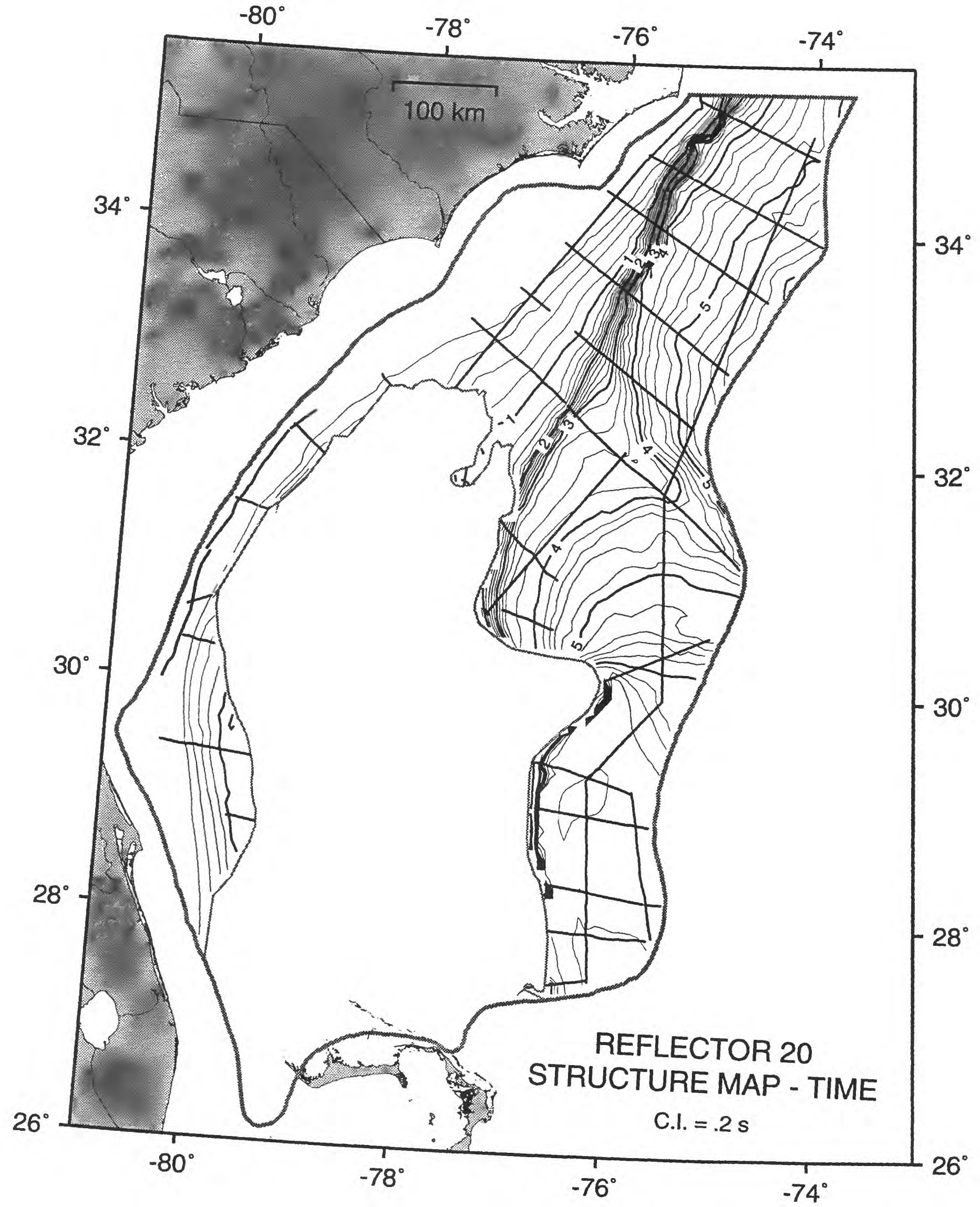




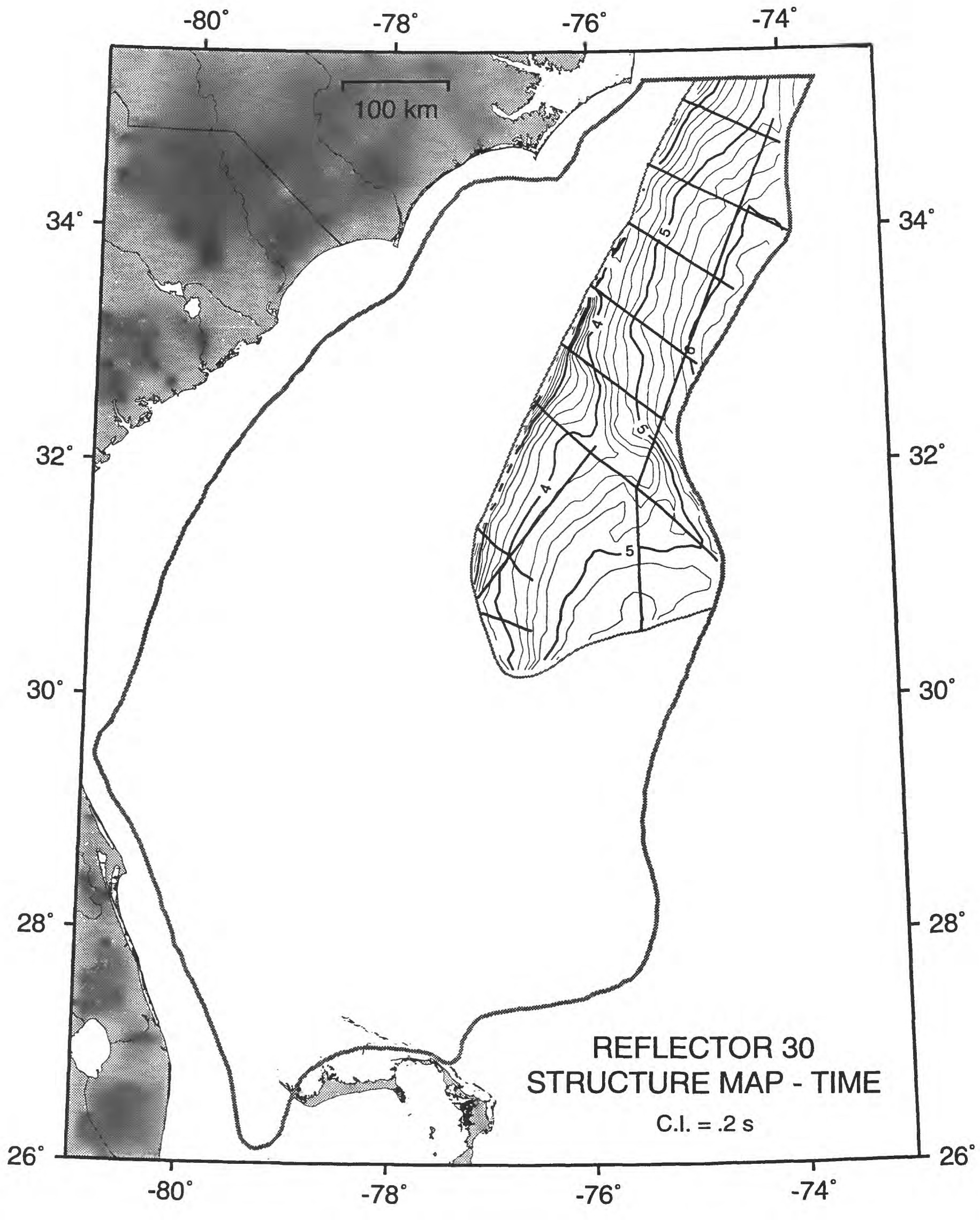




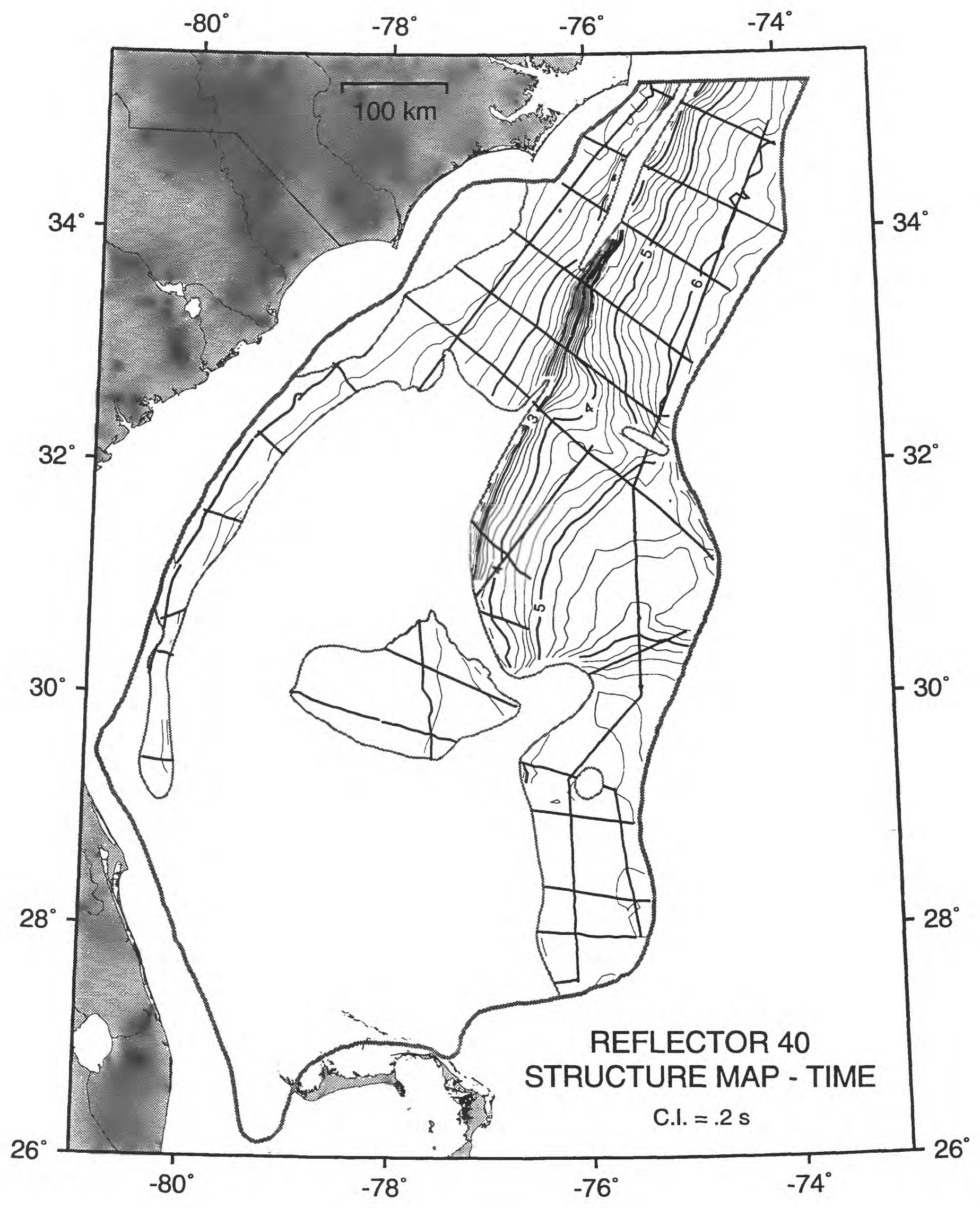




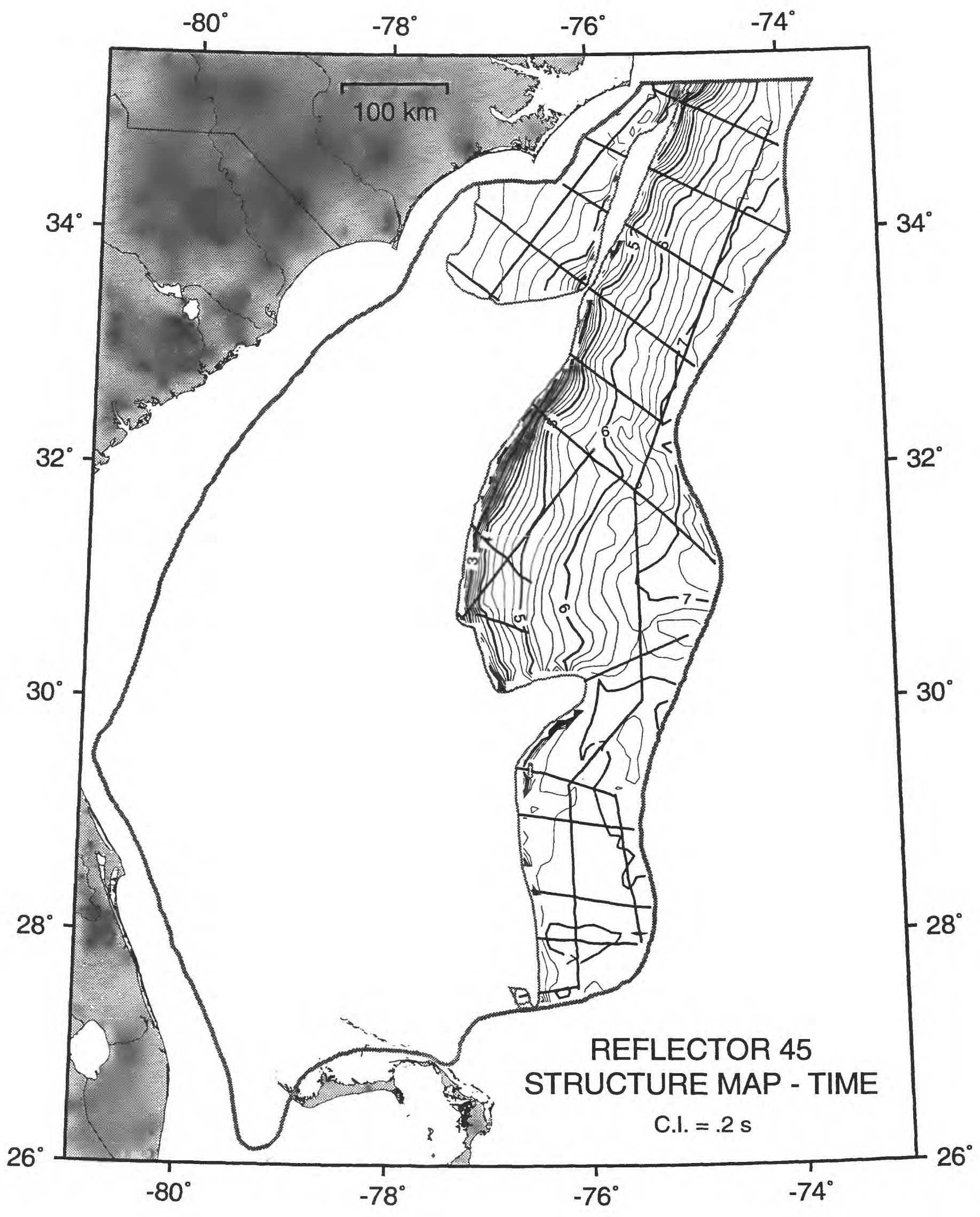




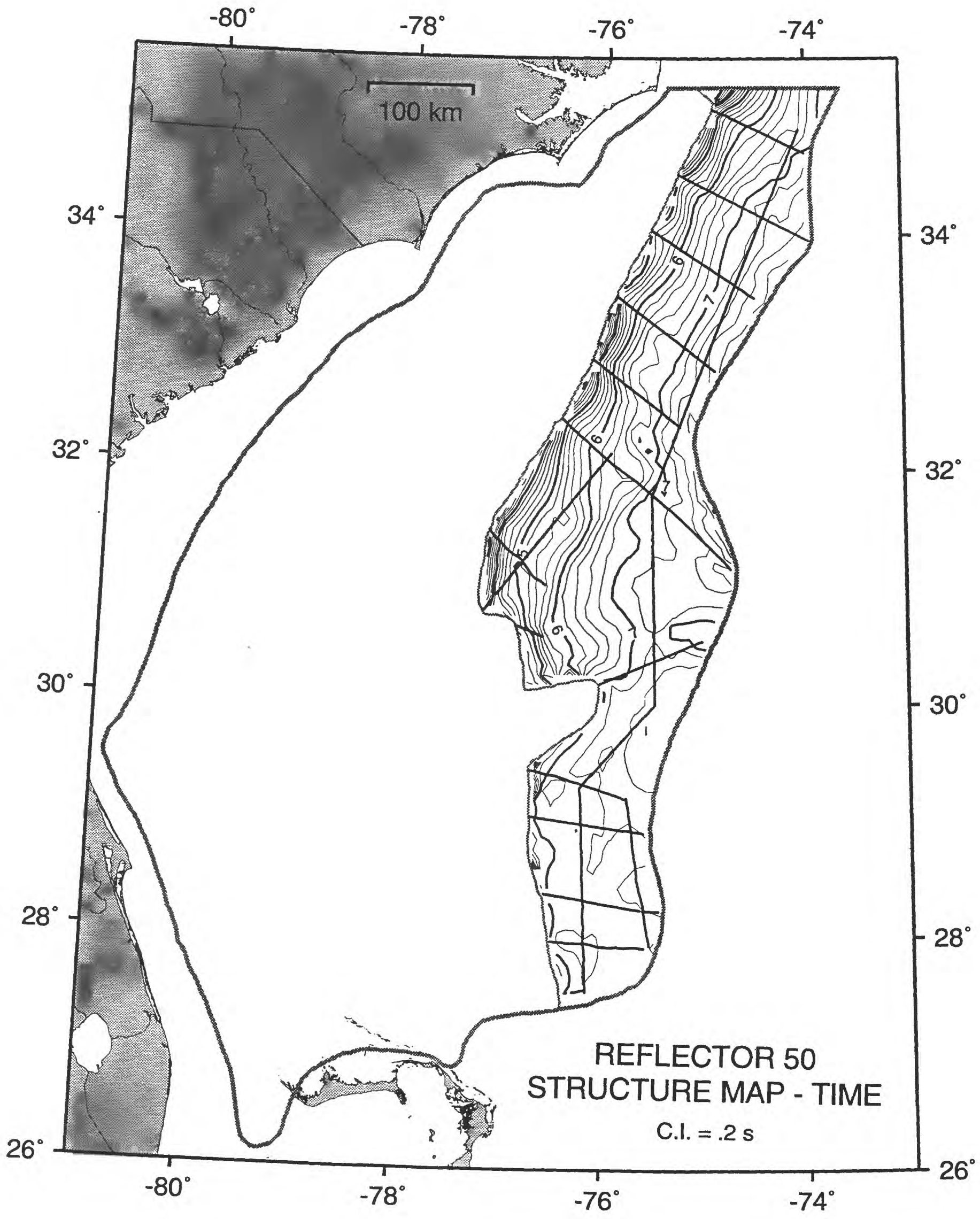




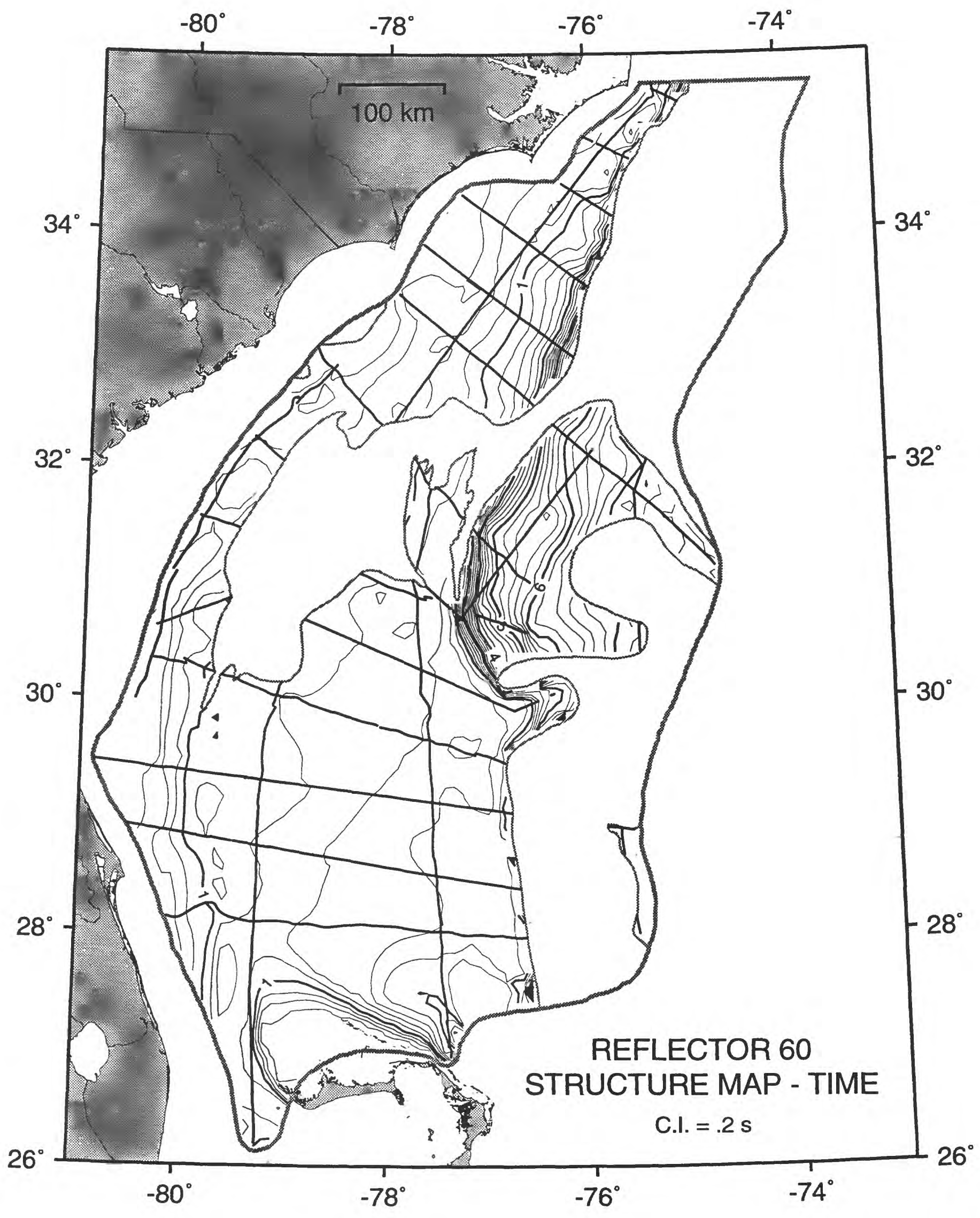




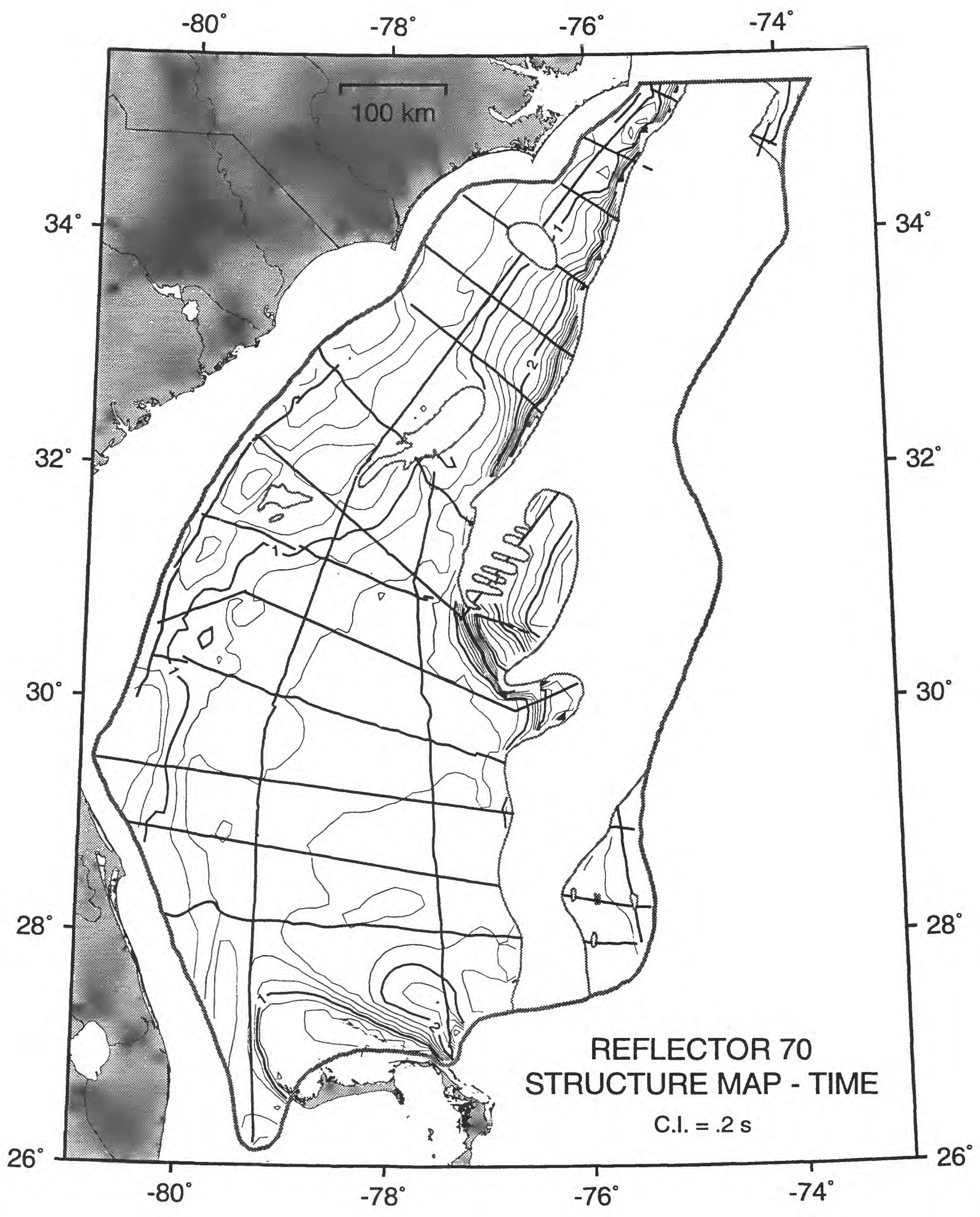




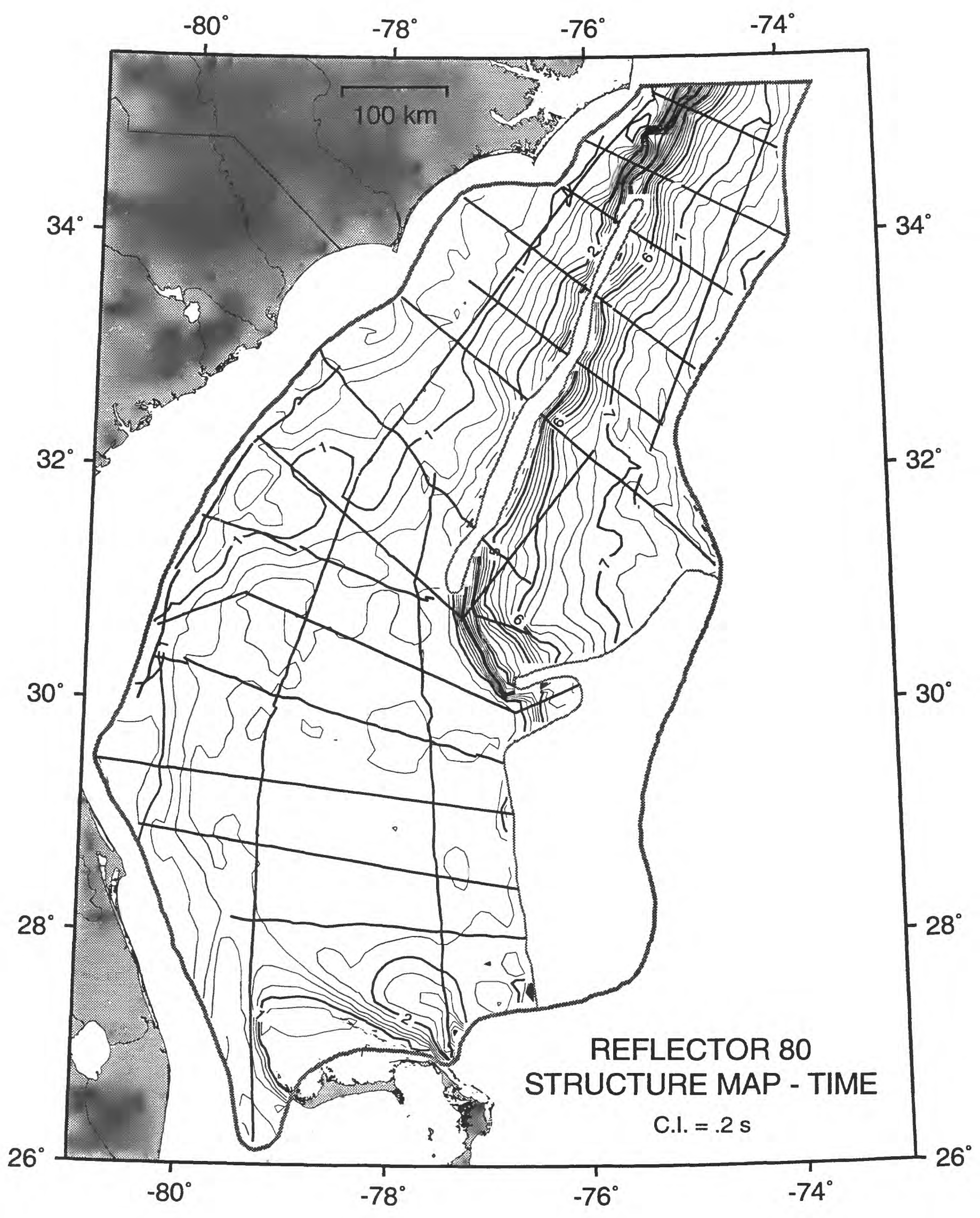




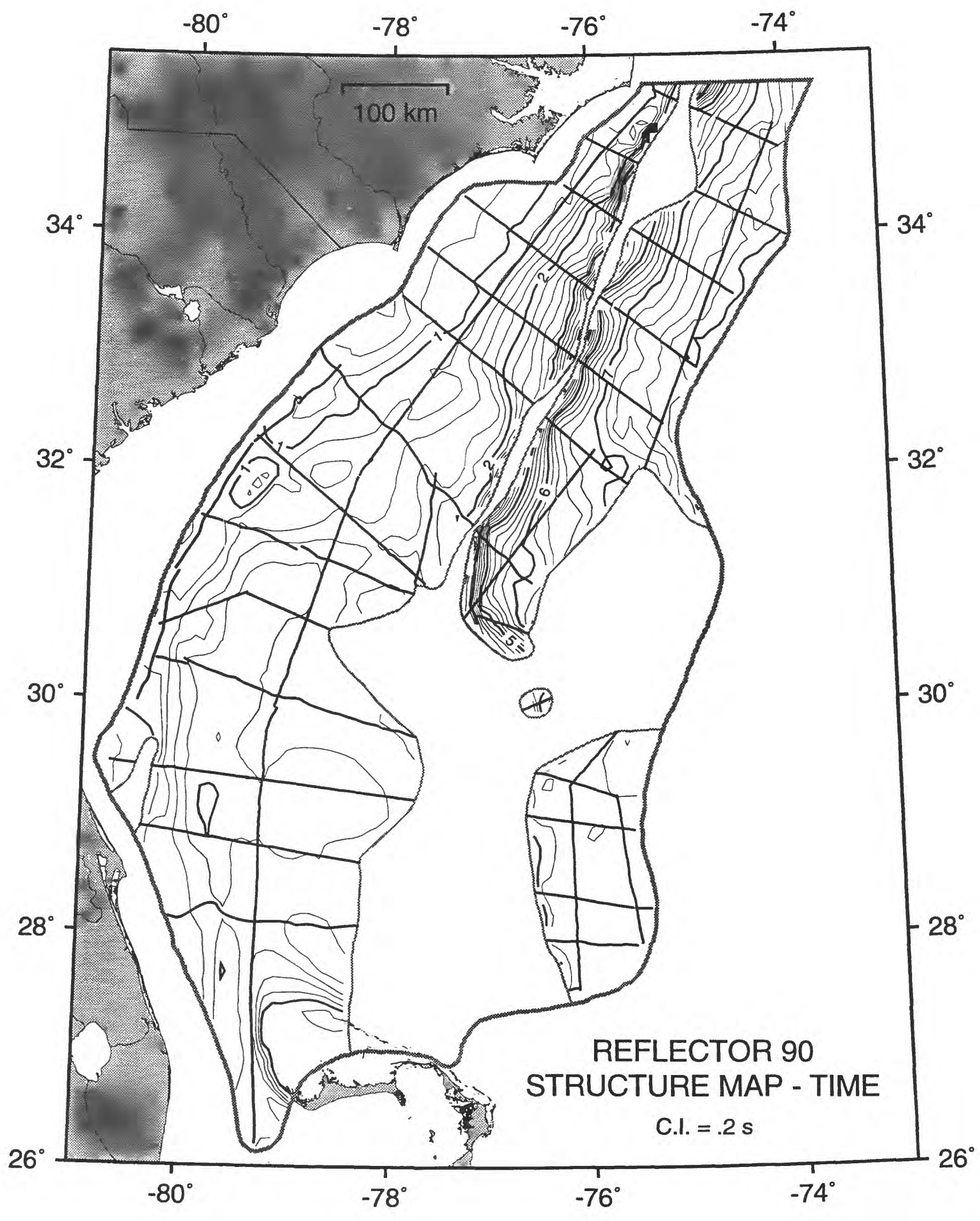




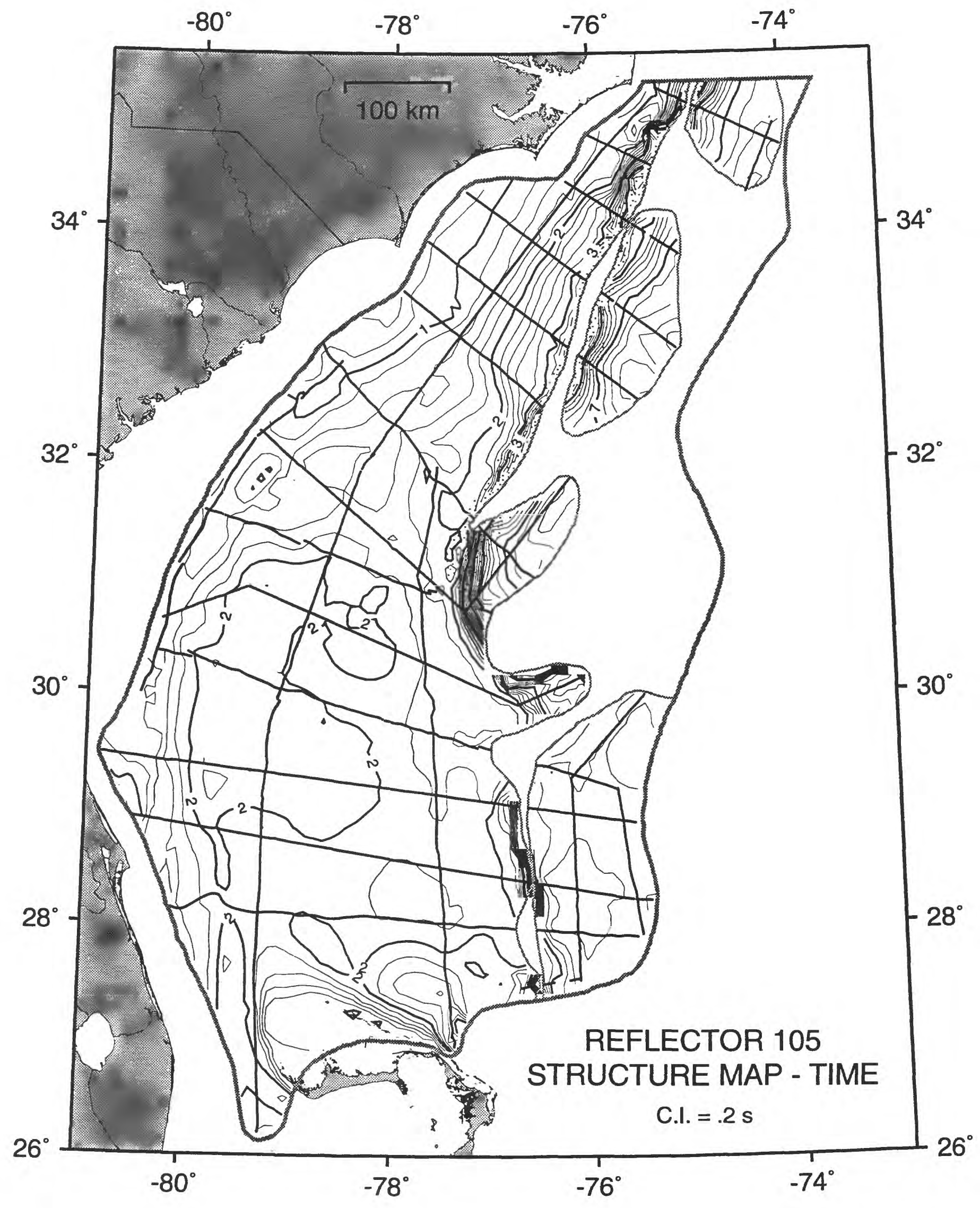




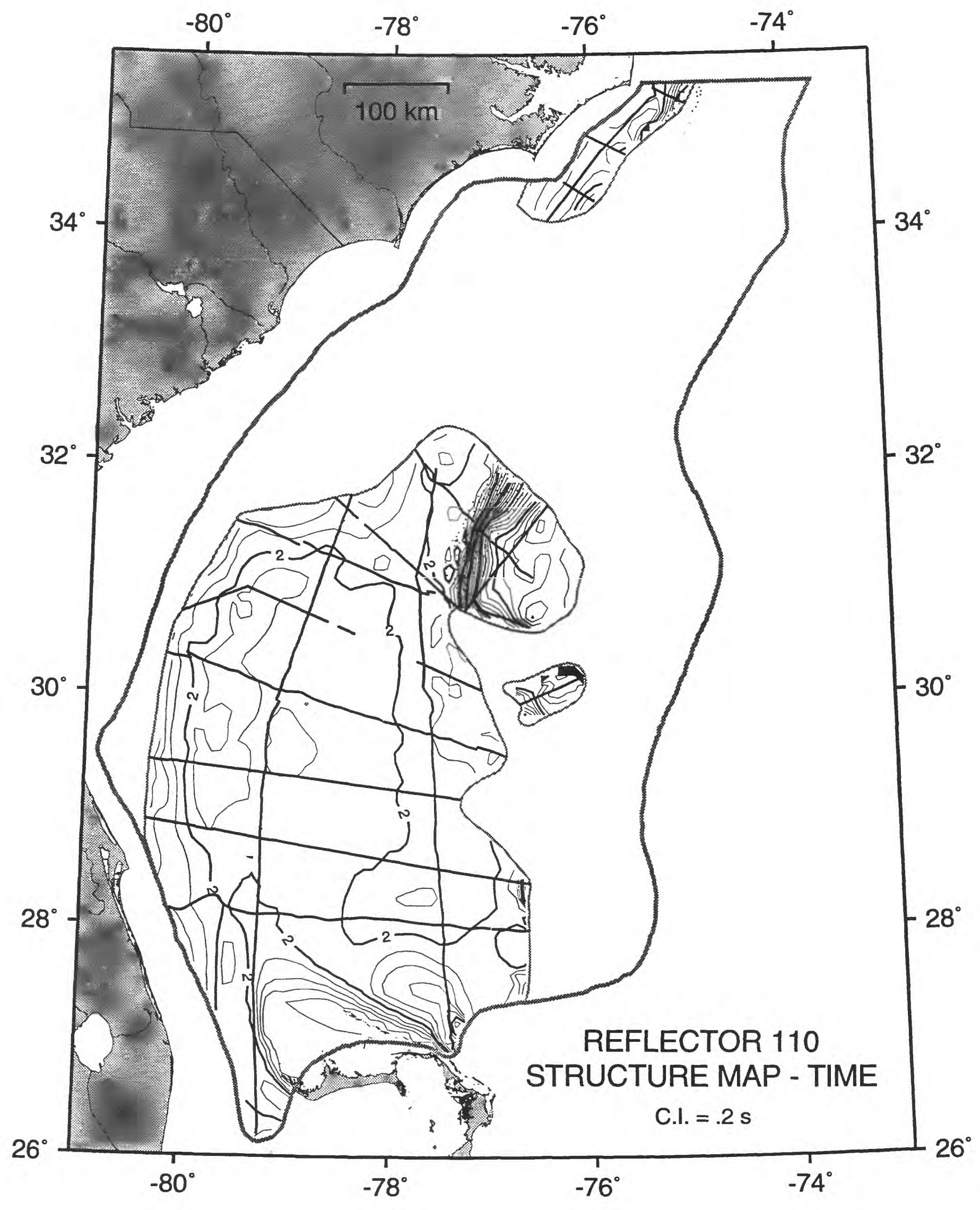




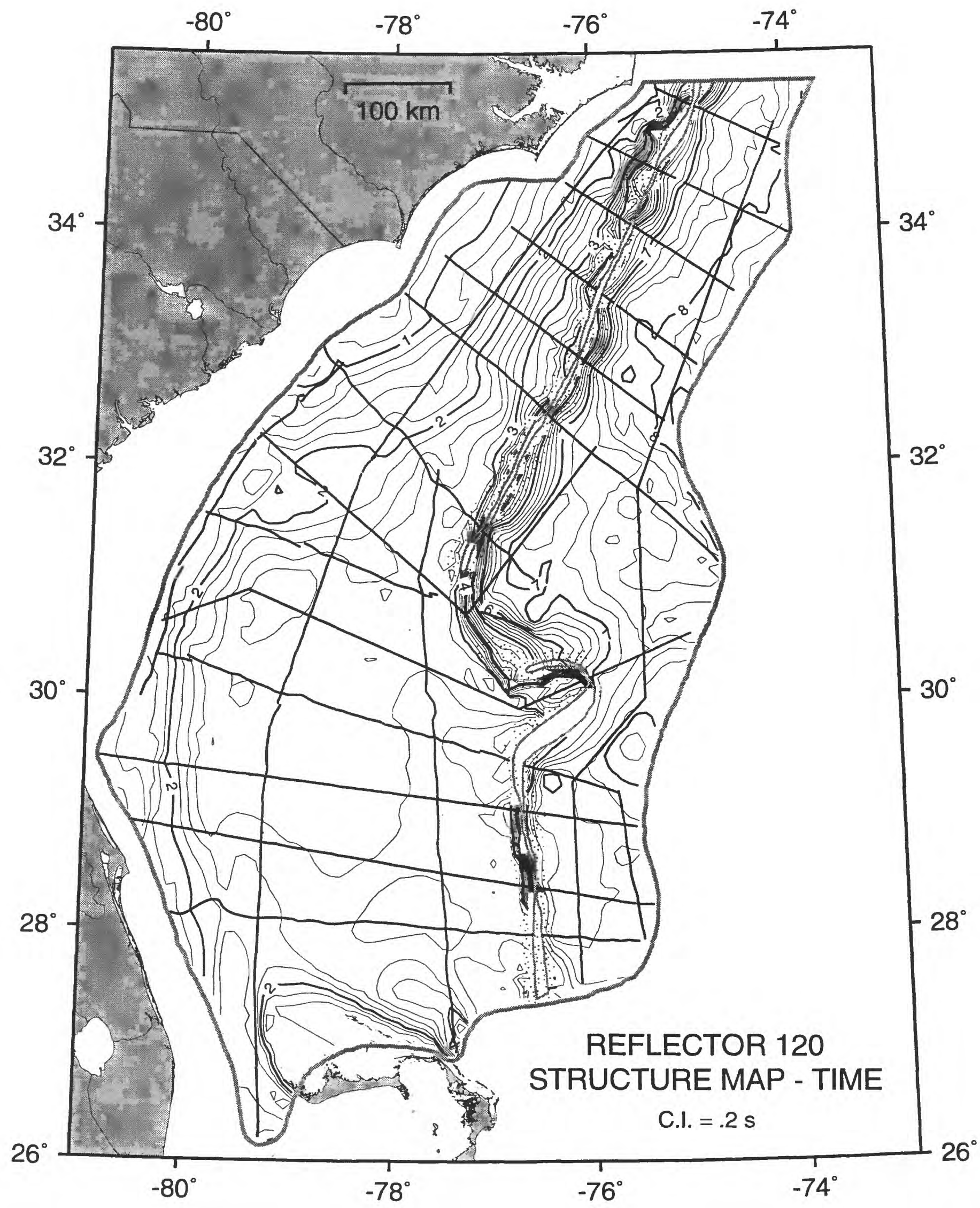




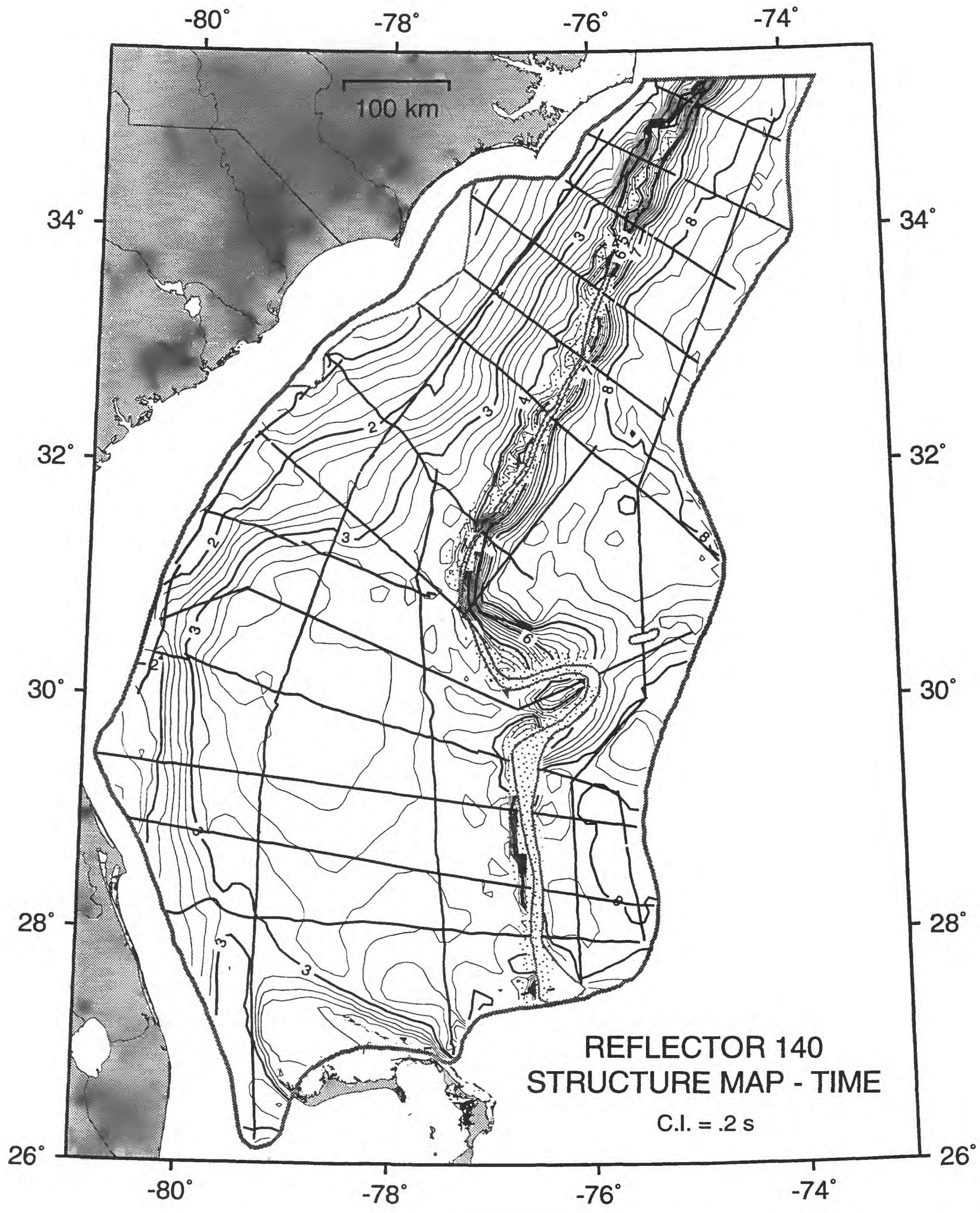




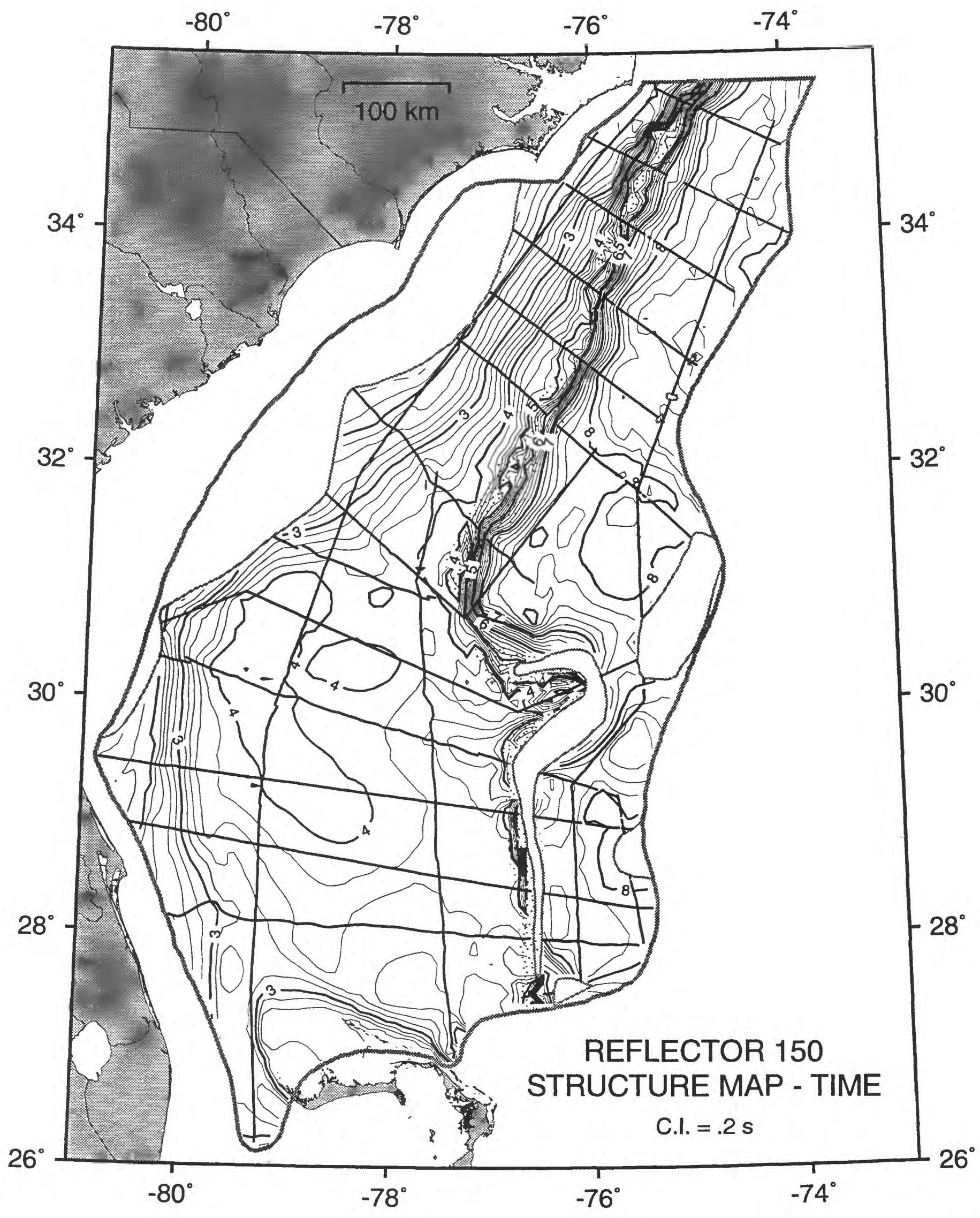




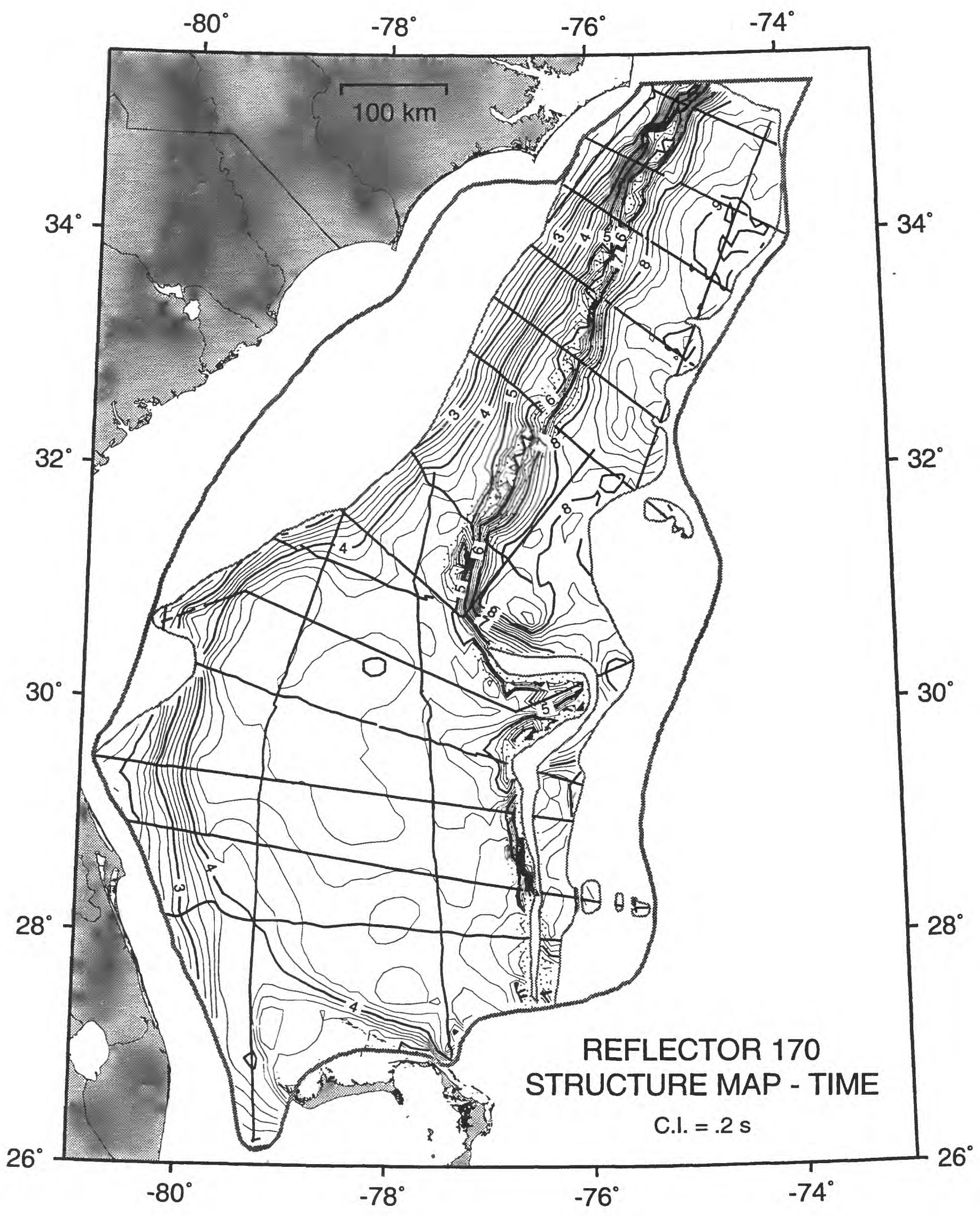




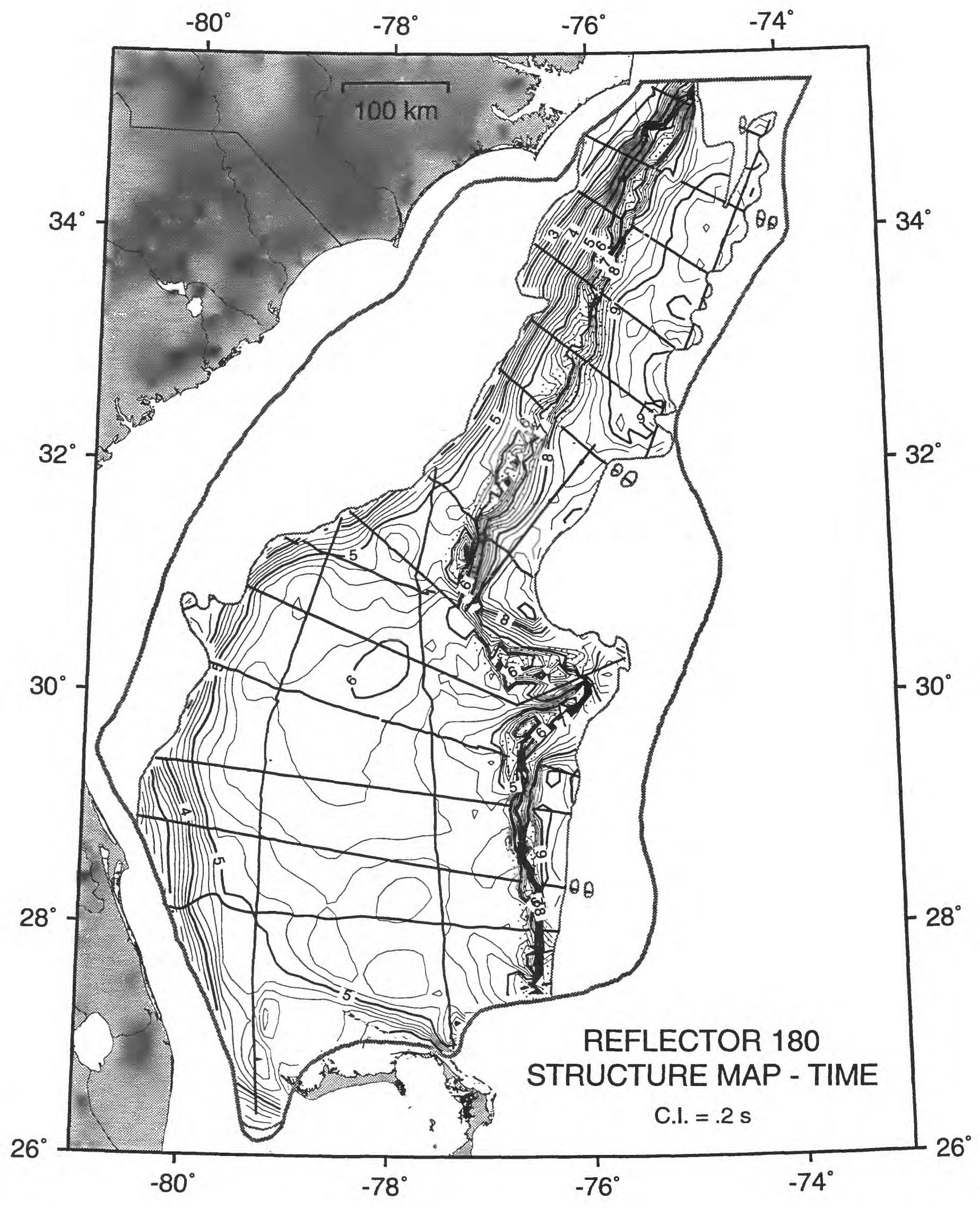




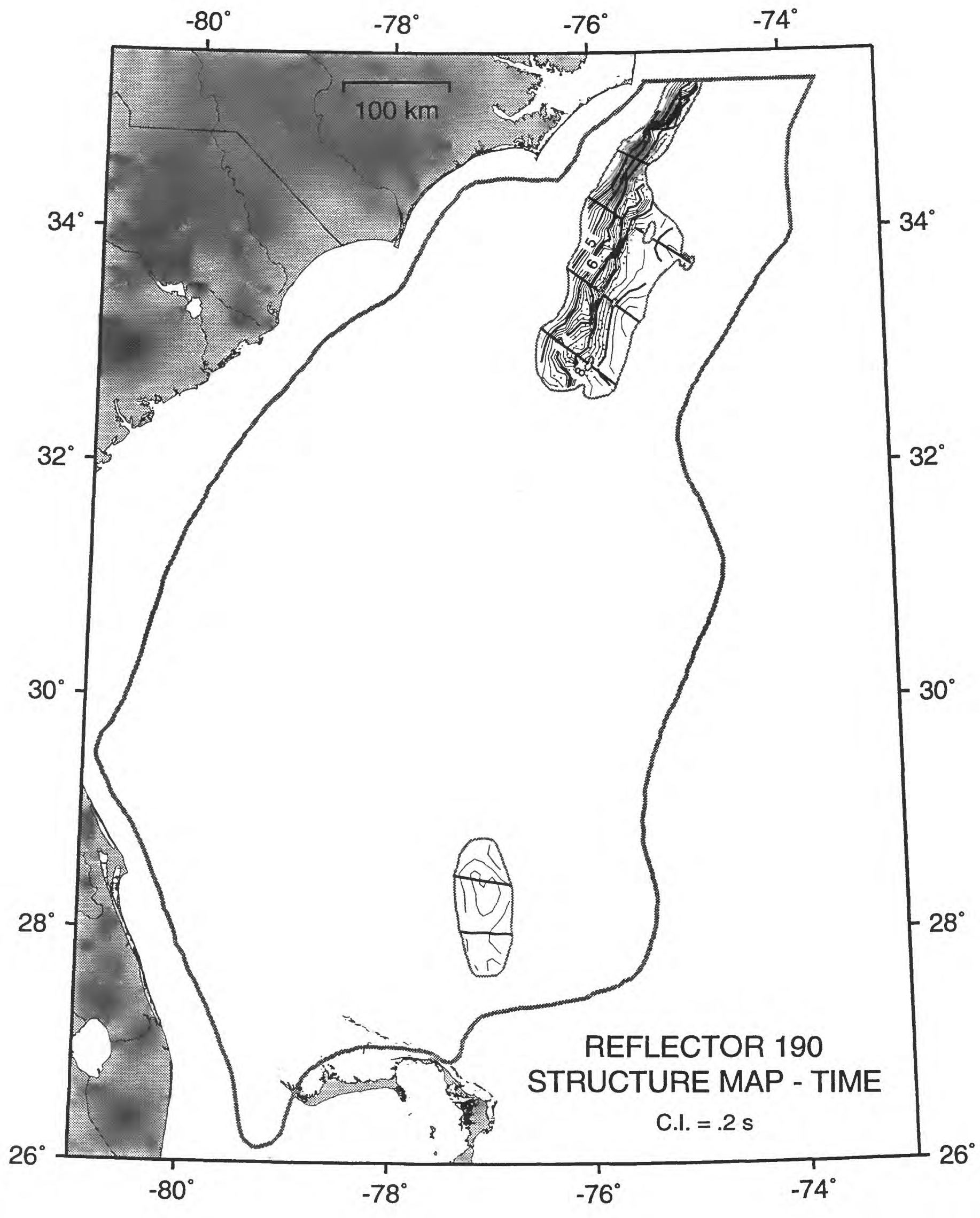




\section{APPENDIX 5}

\section{Gridded Data - Structure Maps in Depth}

This appendix gives contour maps of the depth in meters to the base of each acoustic unit in this data base. The heavy black lines represent locations of seismic profiles used to generate the maps. Regions of no contours are outlined and indicate places where the surface is absent. Maps for reflectors 105 - 190 include stippling along the Carolina Slope and Blake Escarpment to show areas where artifacts in the gridding and contouring exist. Contour interval is $200 \mathrm{~m}$. 


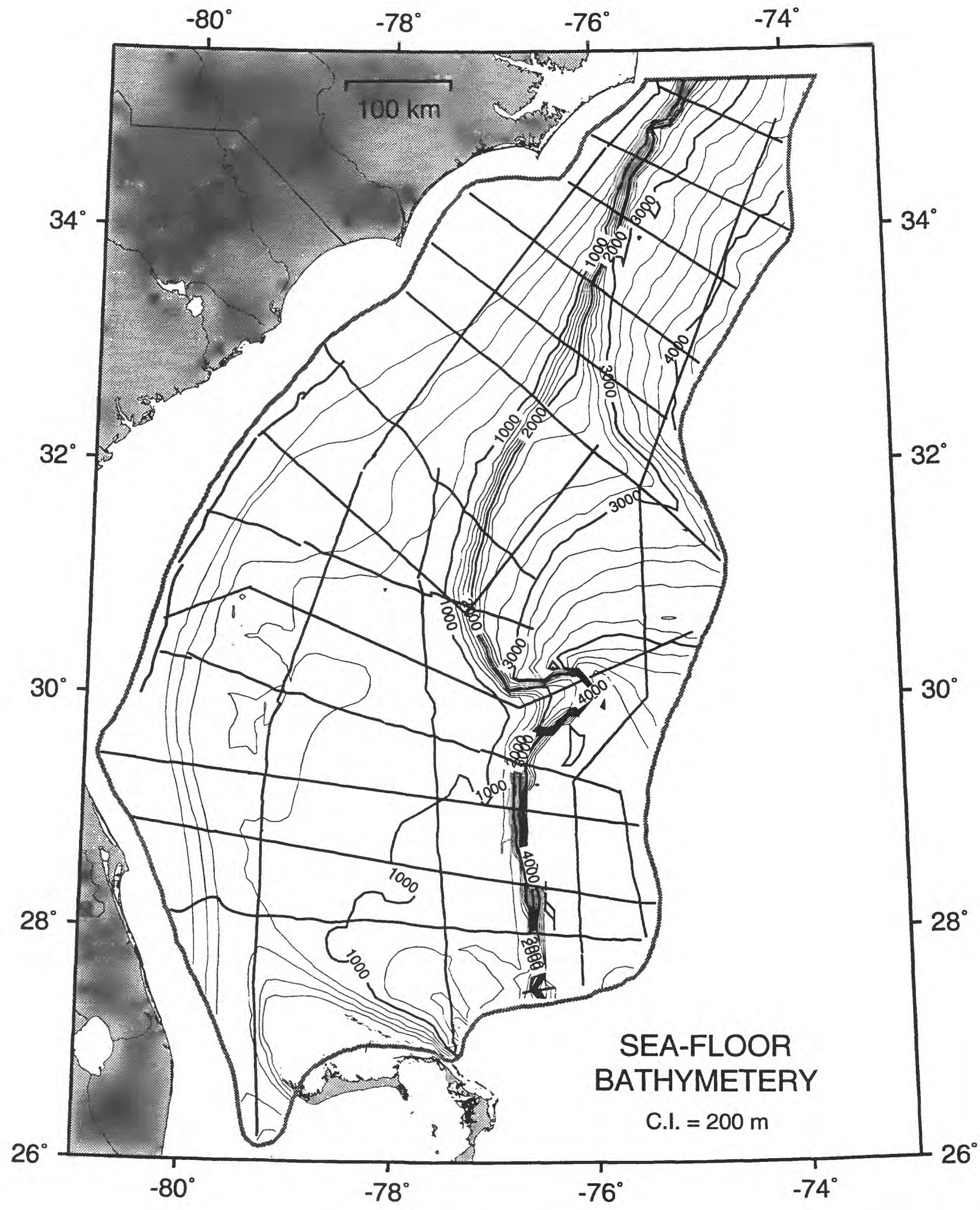




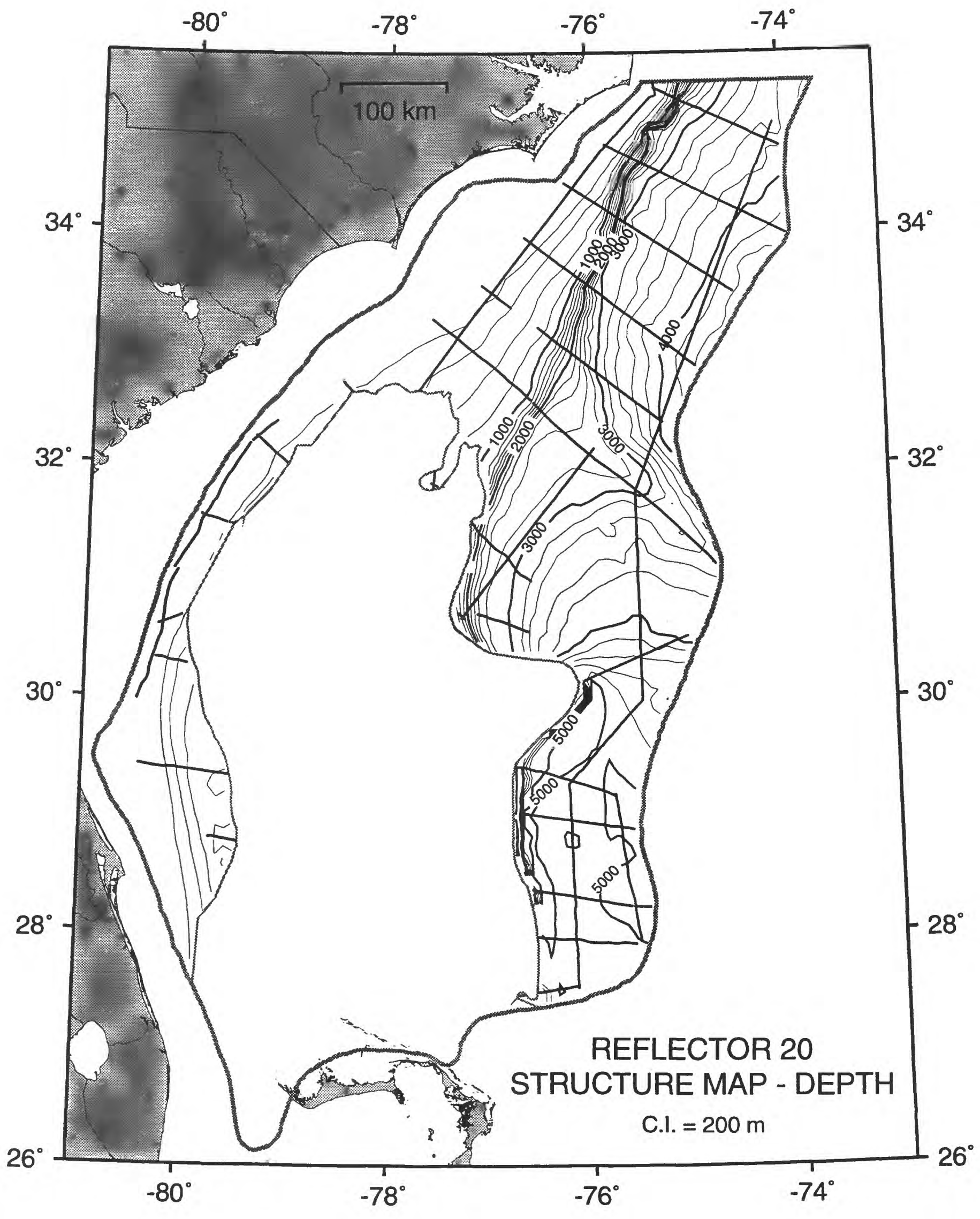




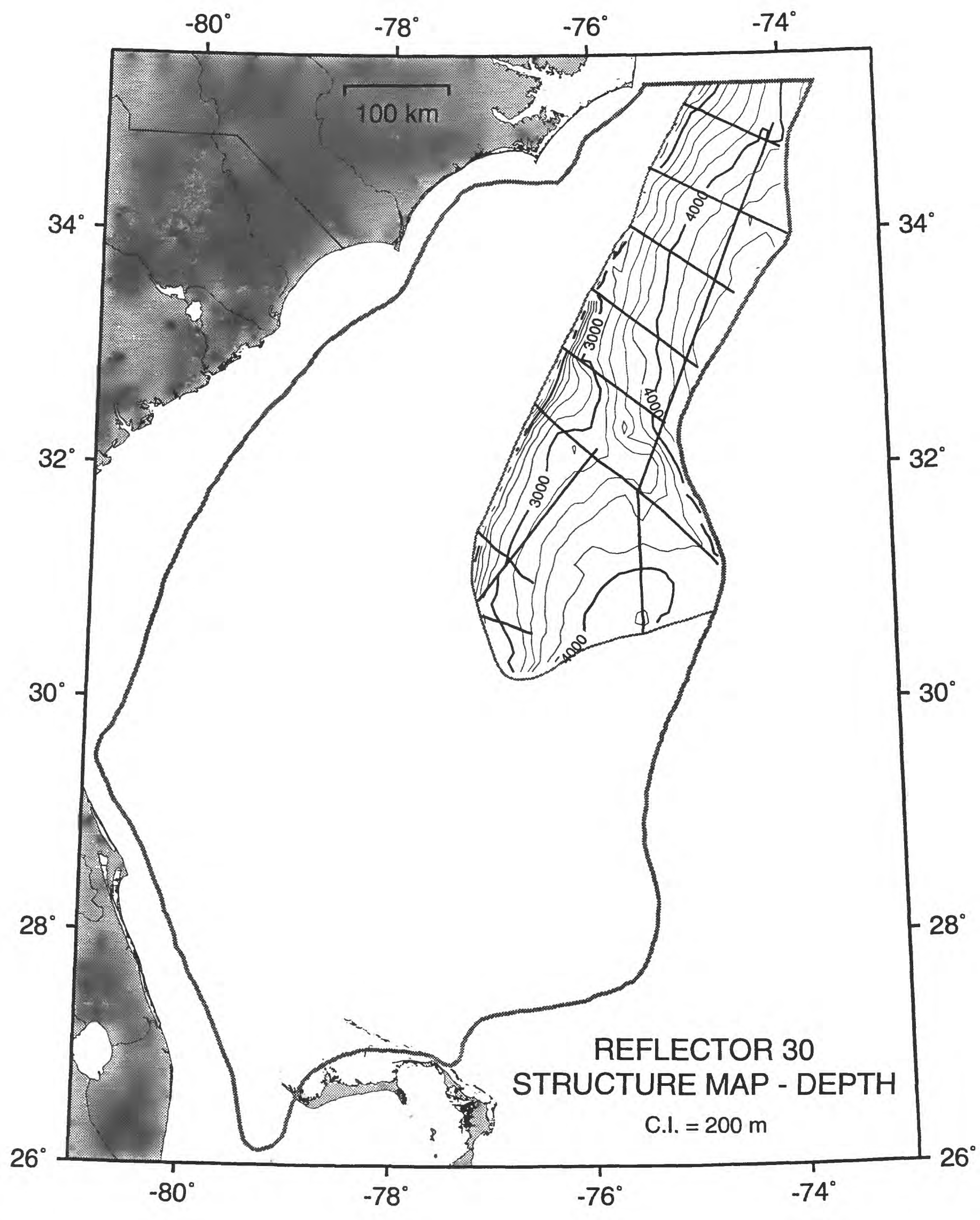




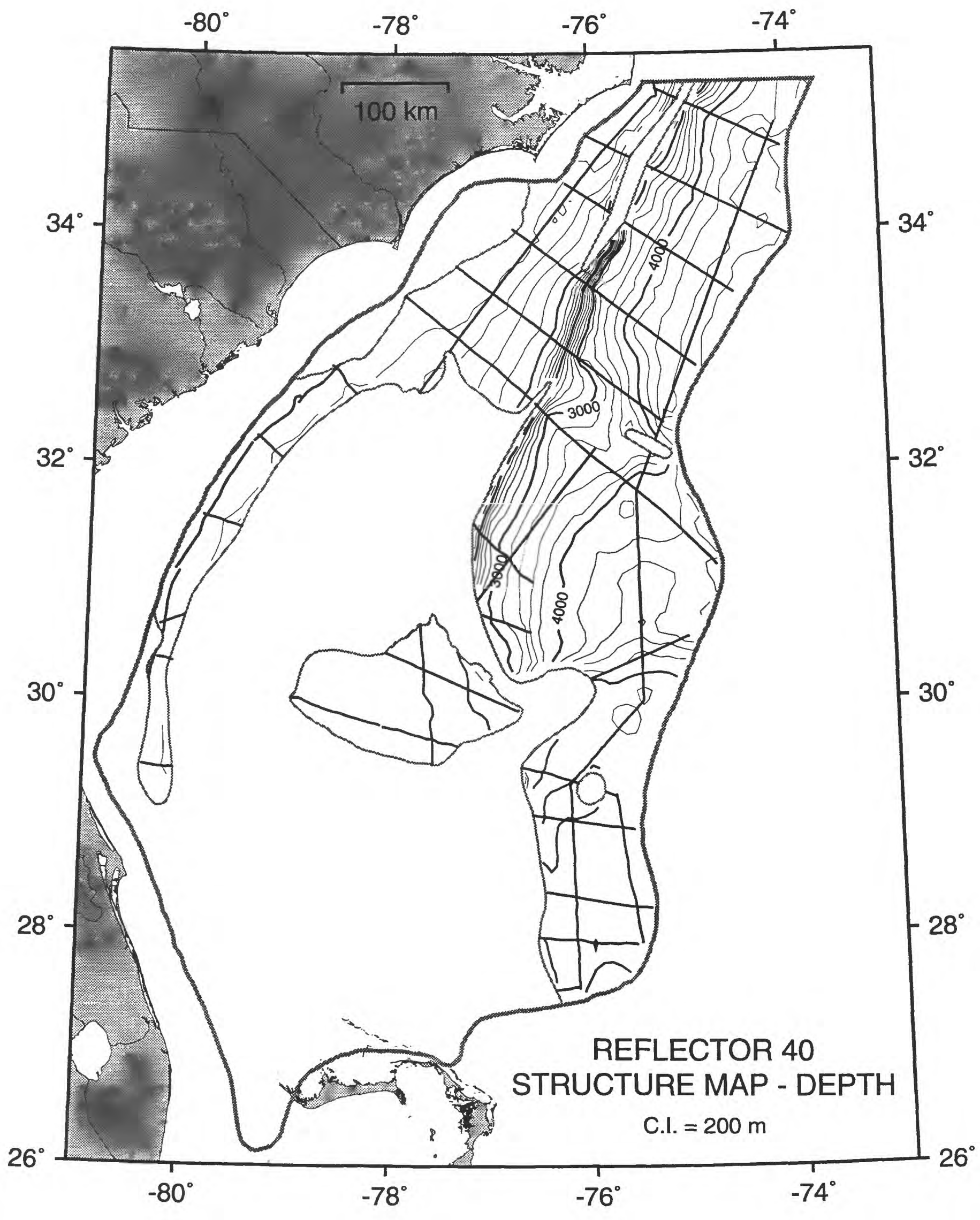




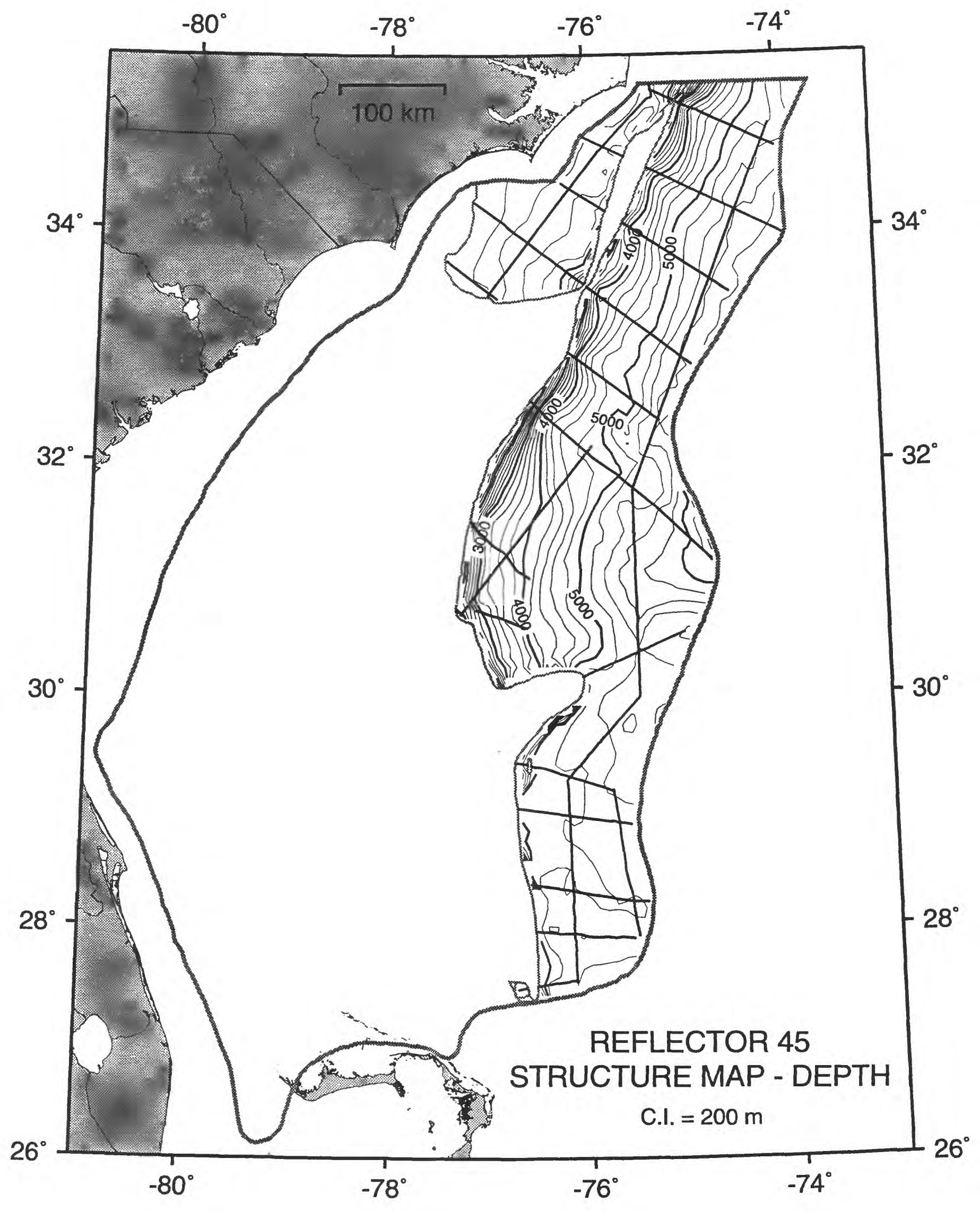




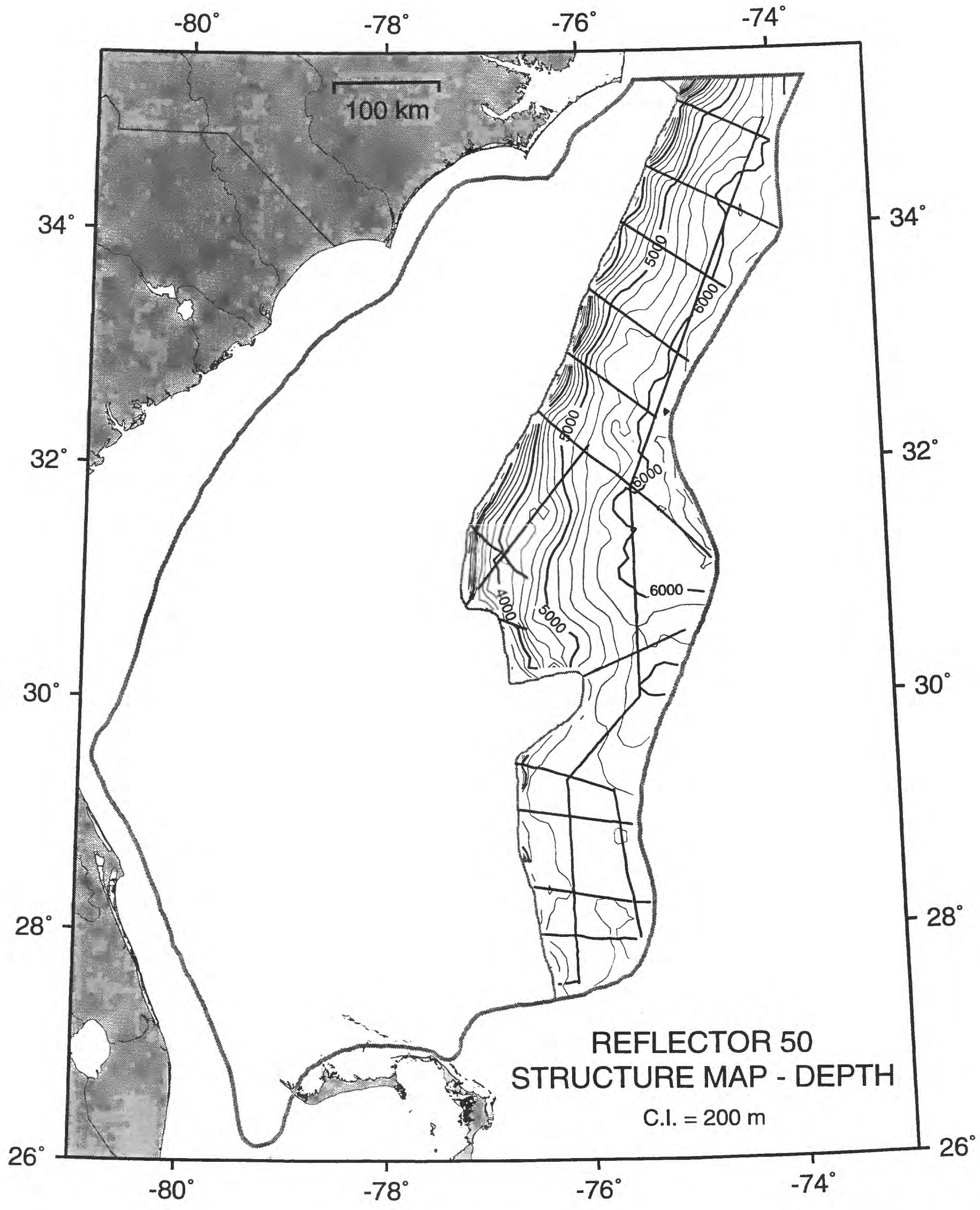




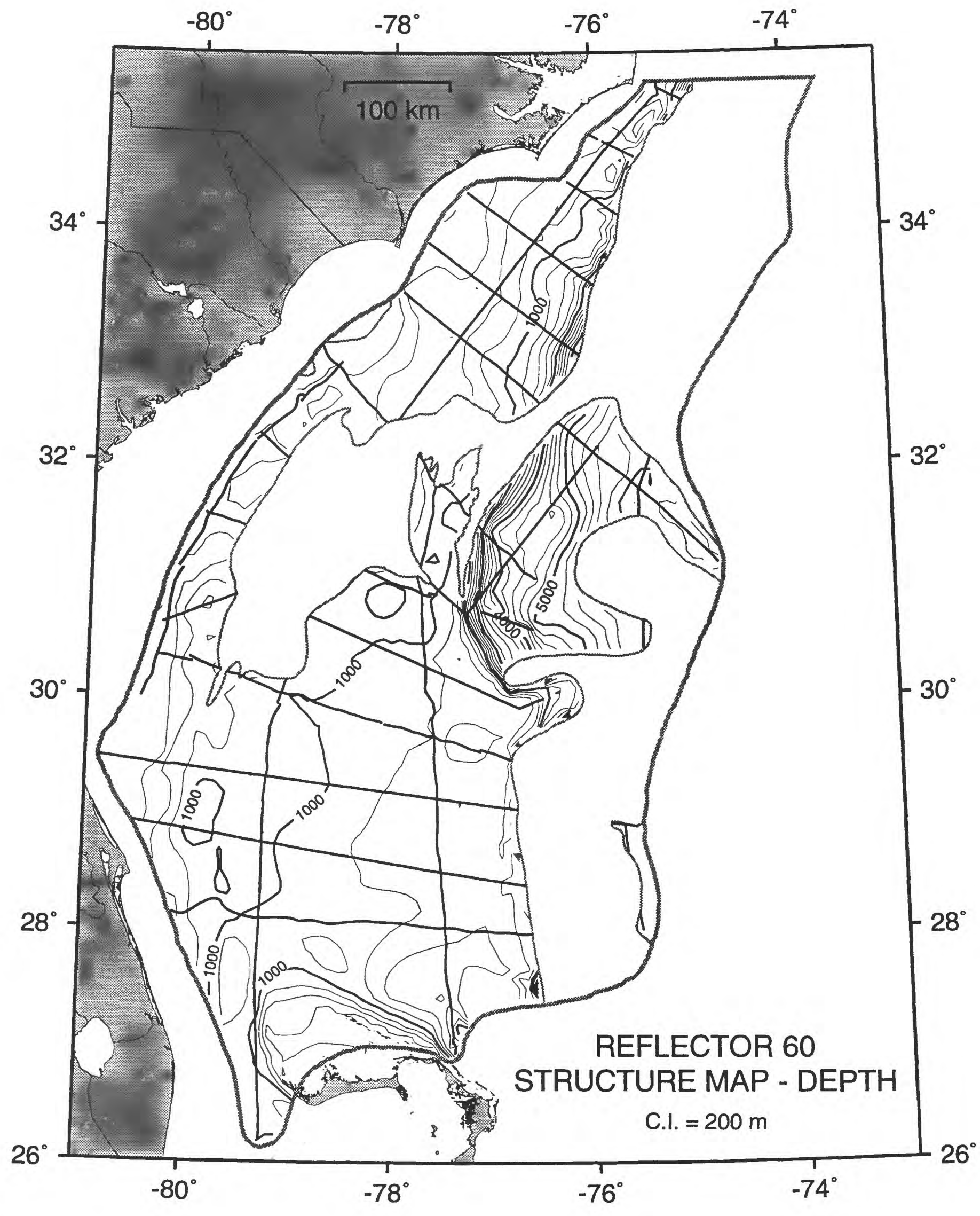




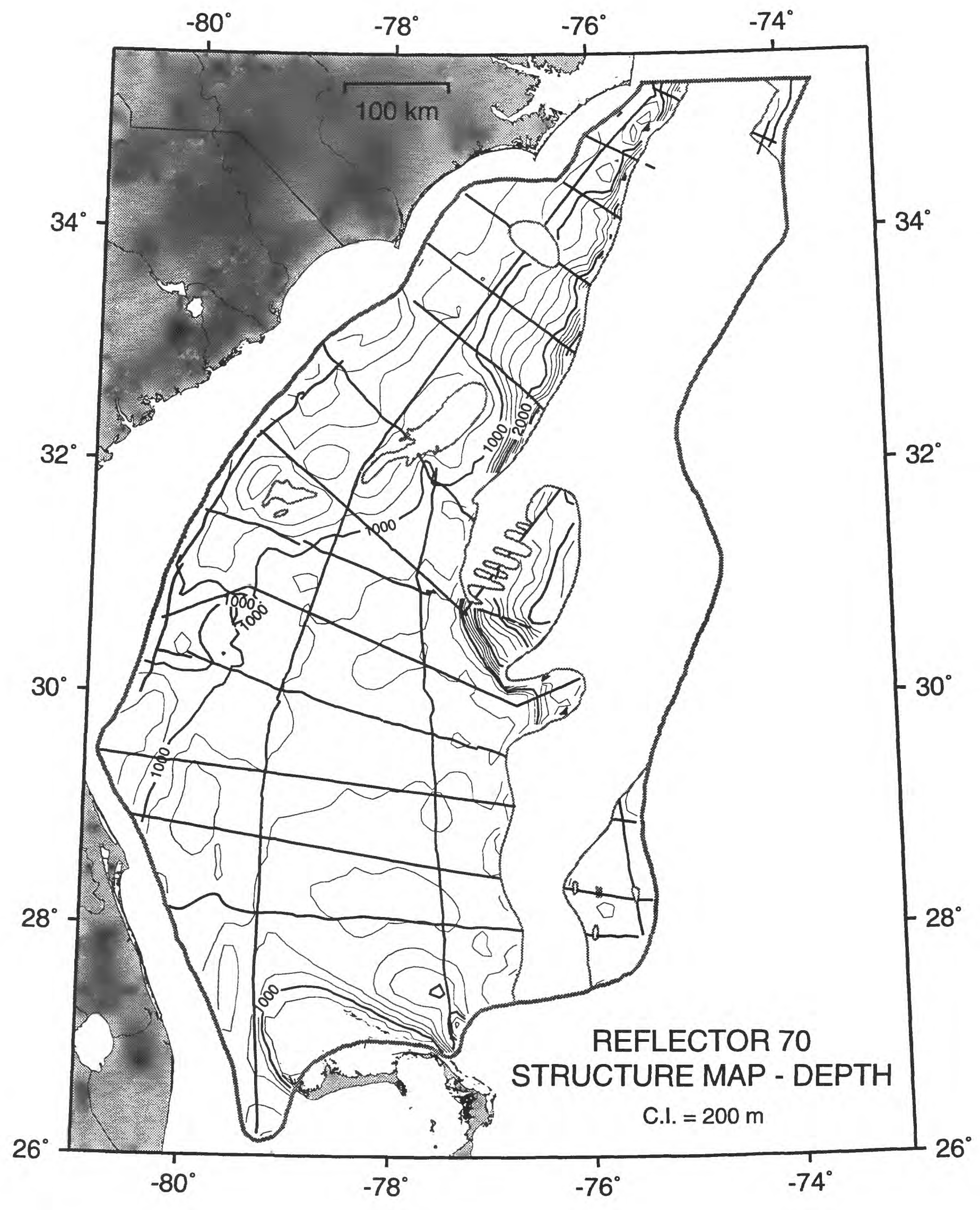




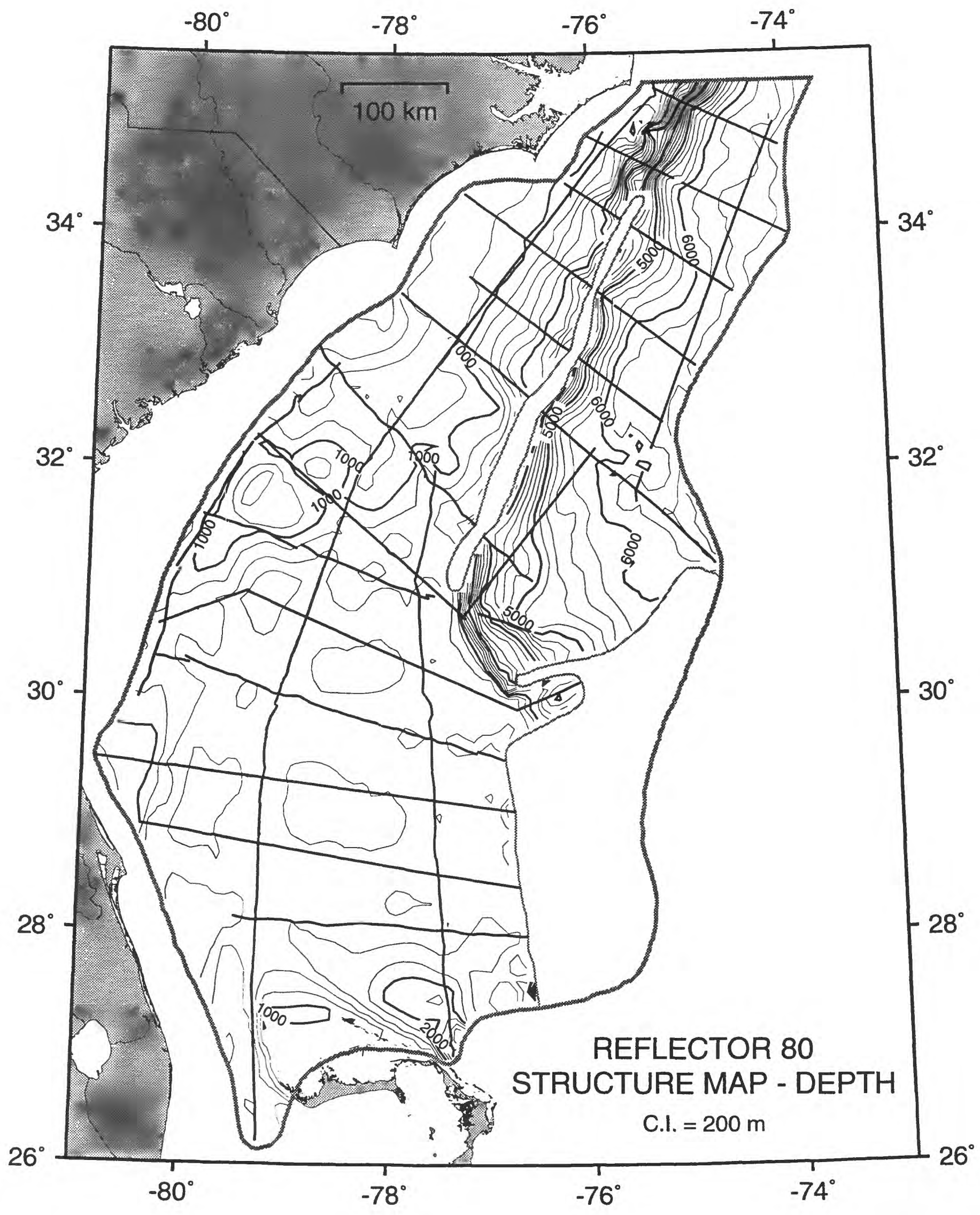




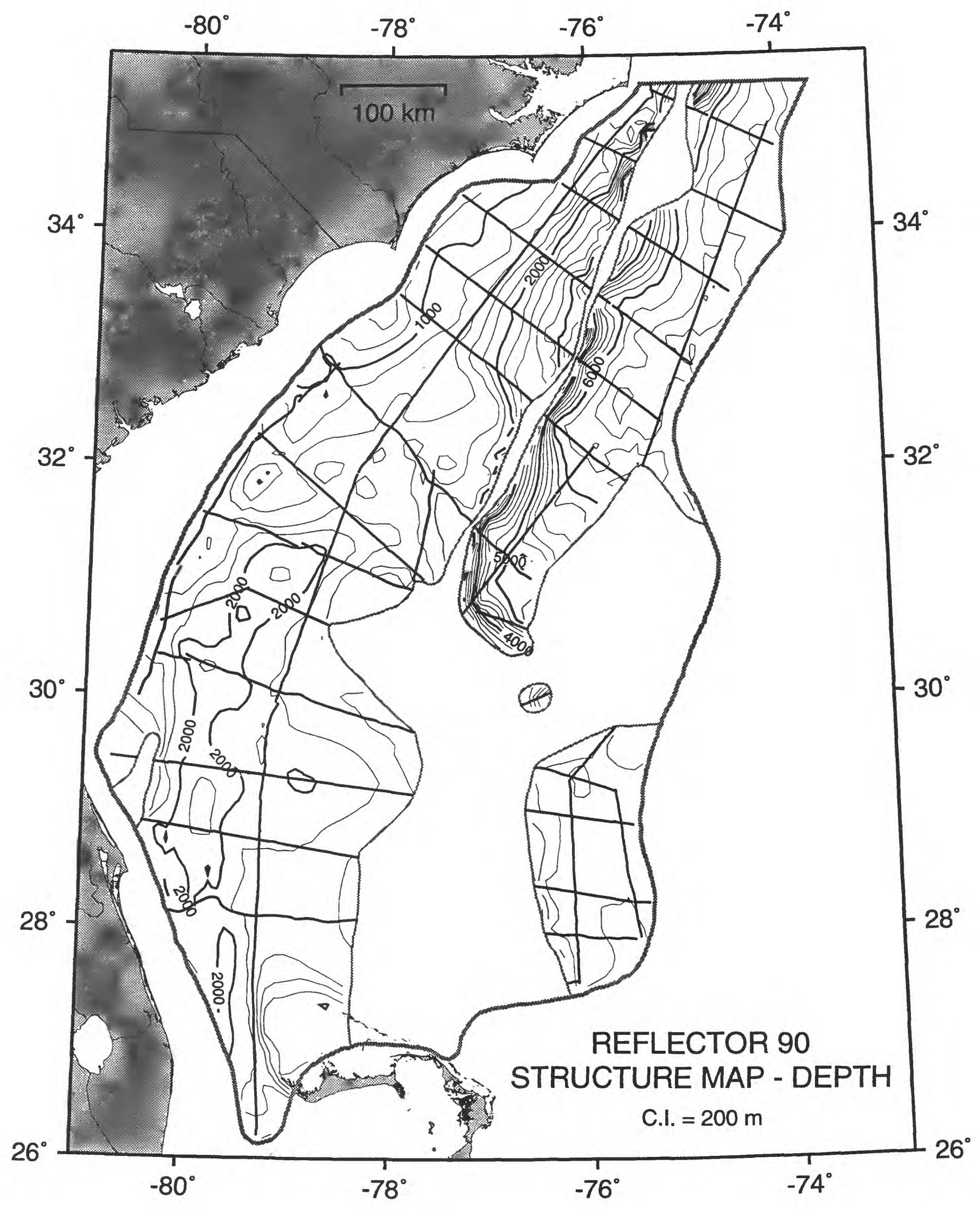




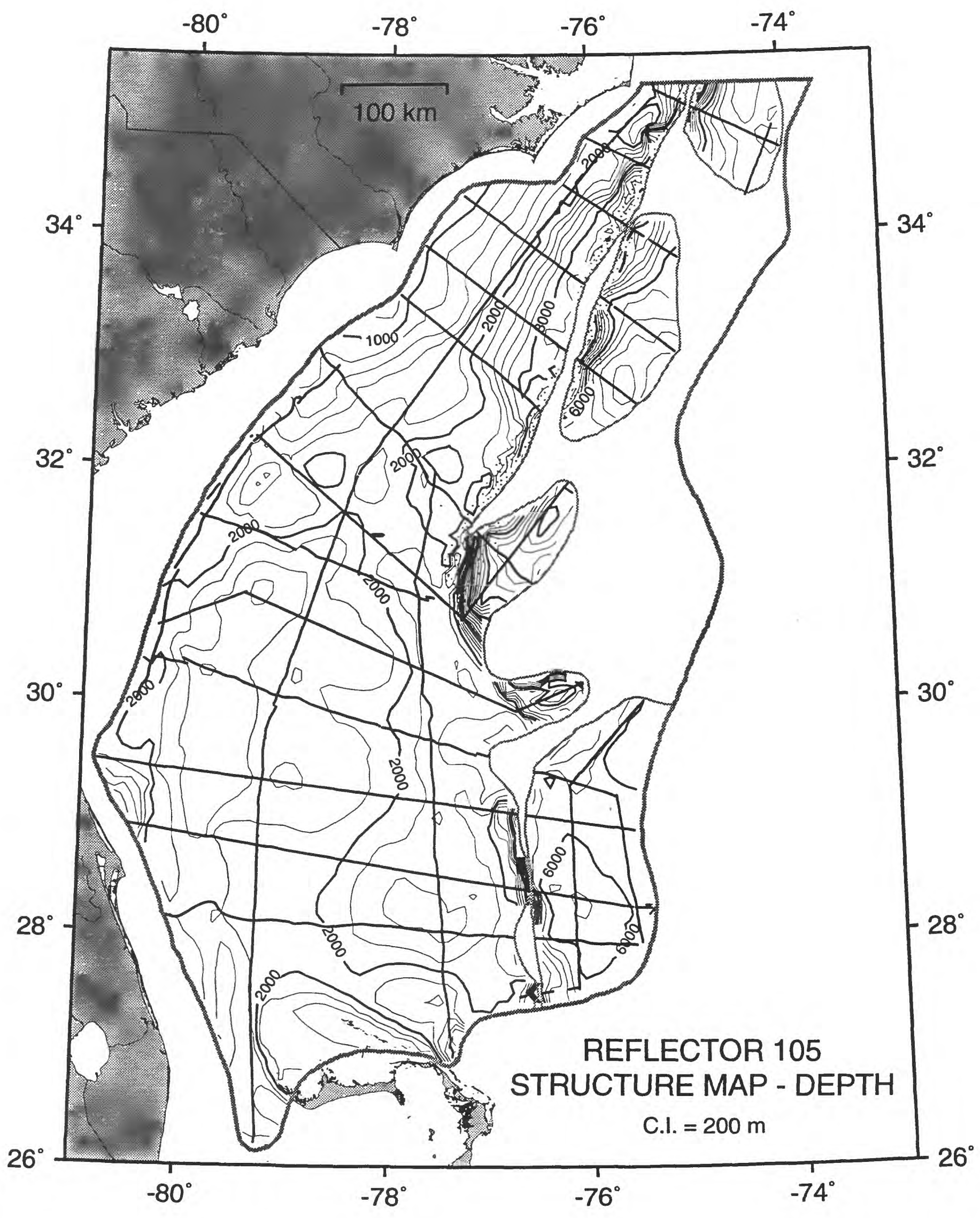




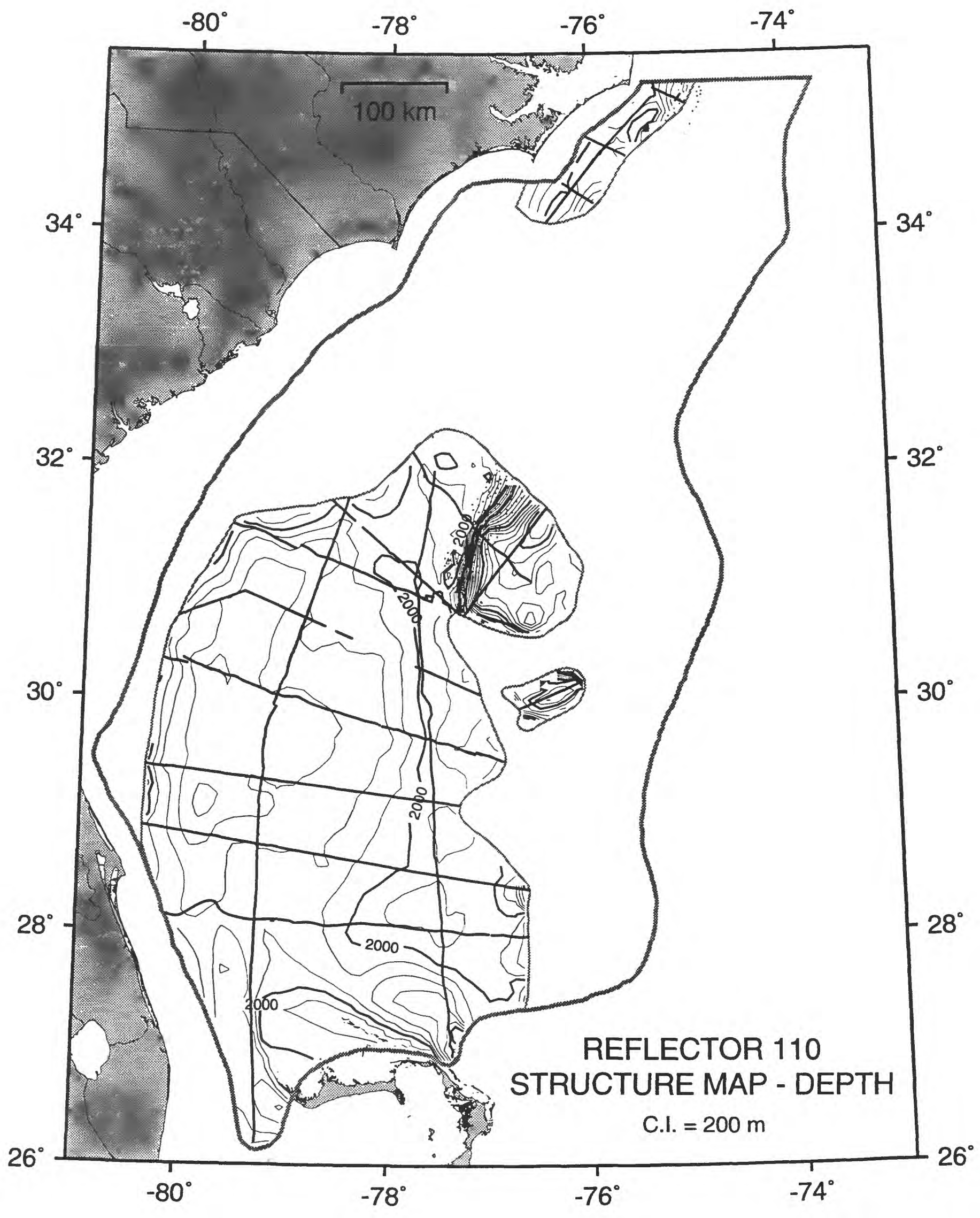




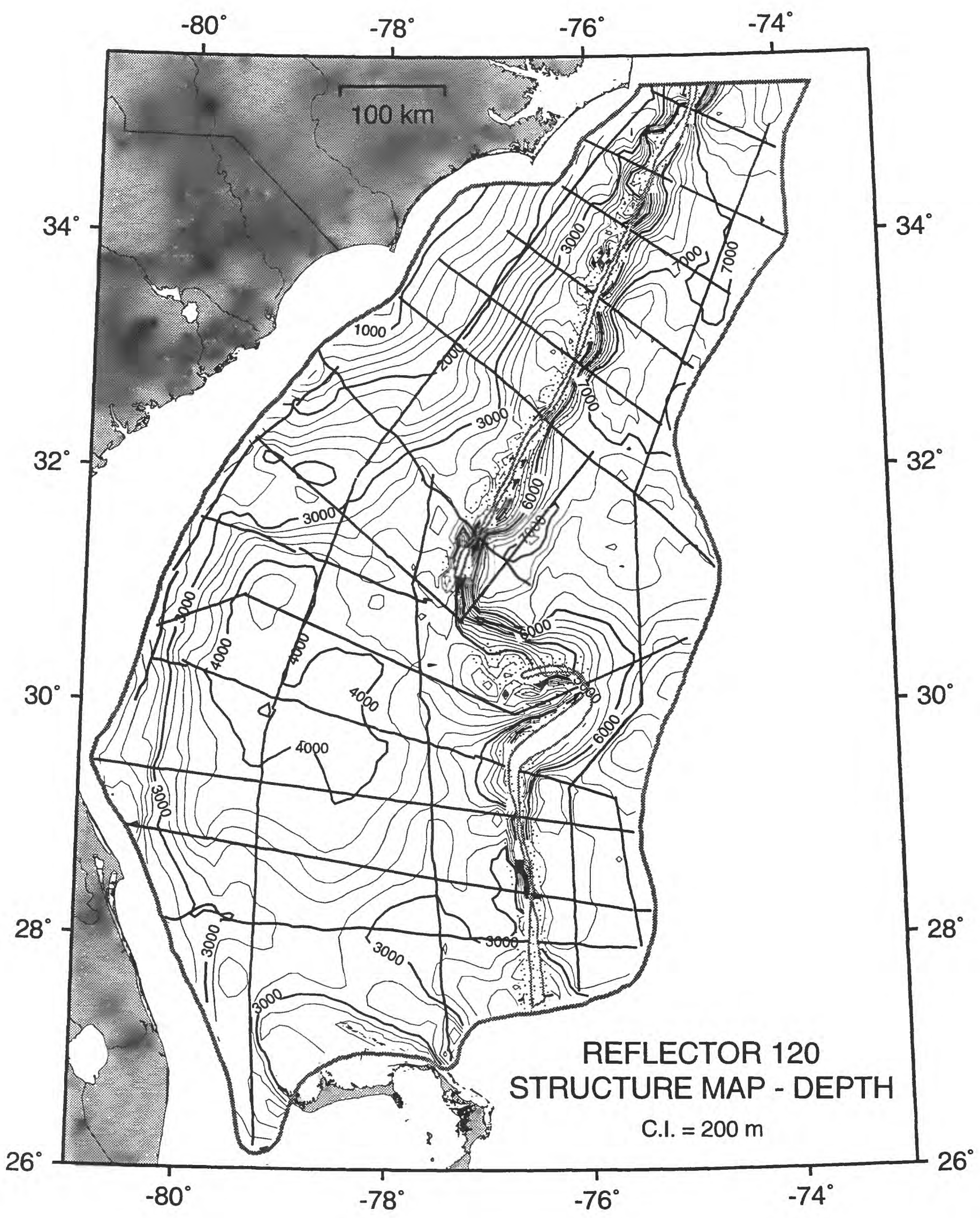




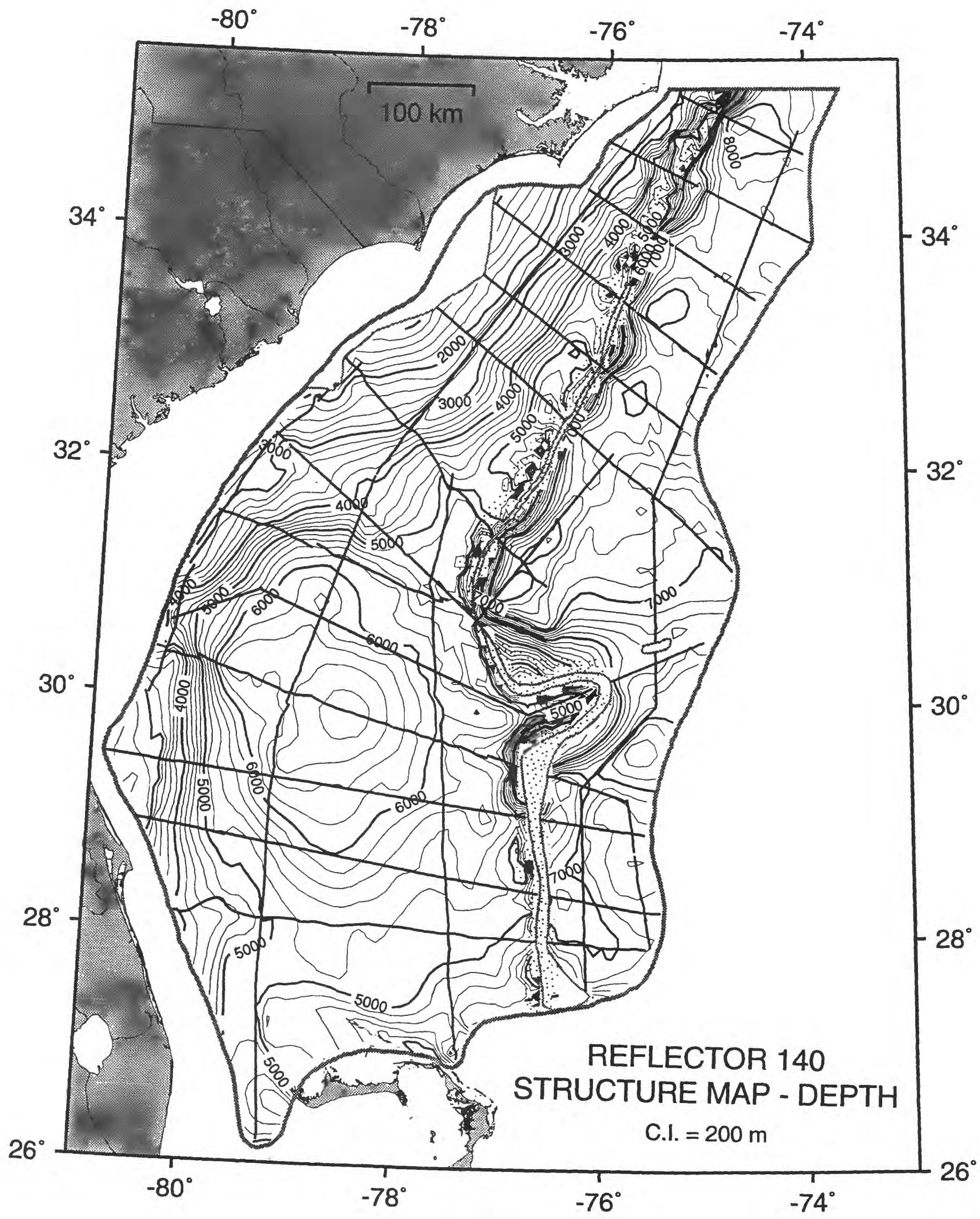




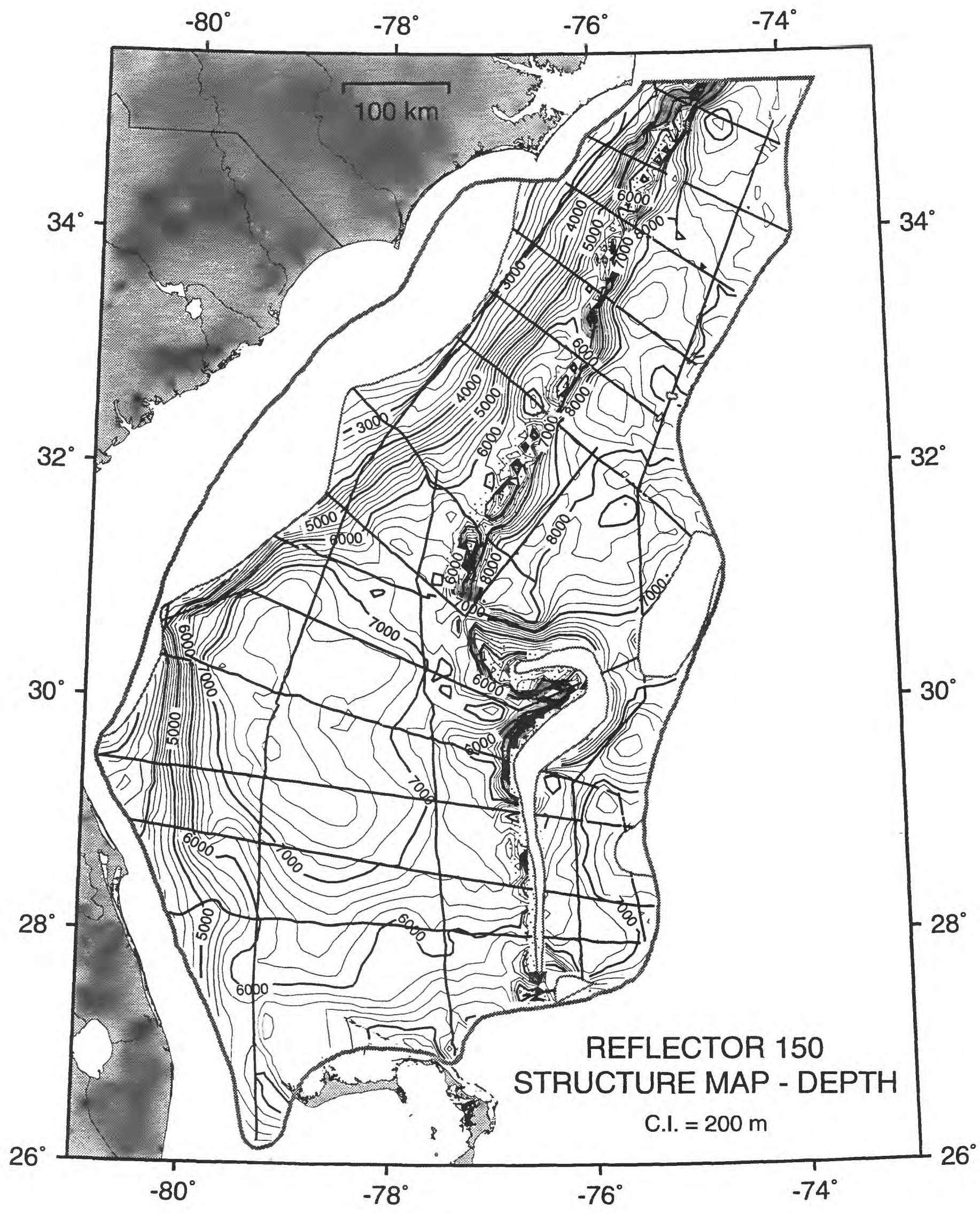




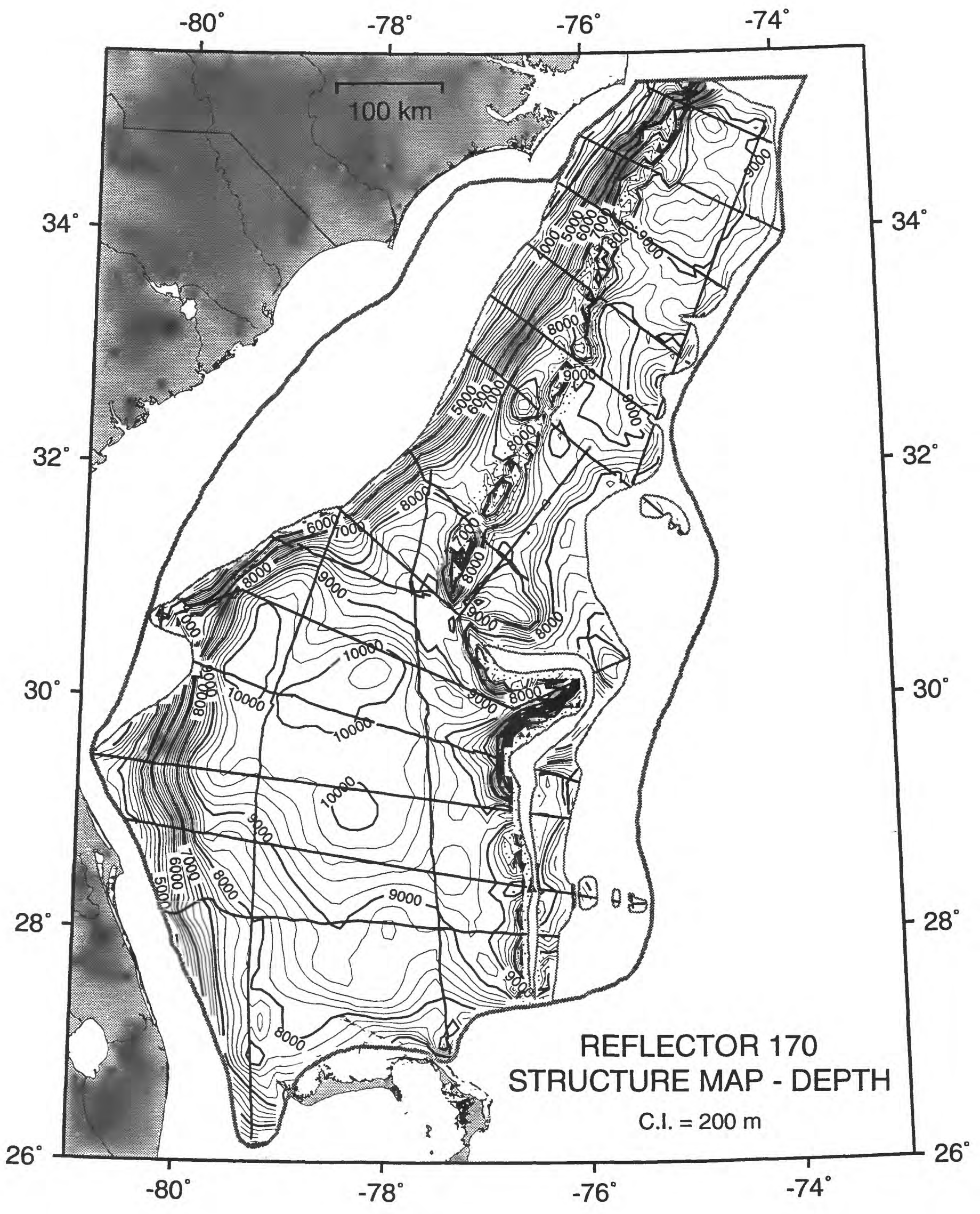




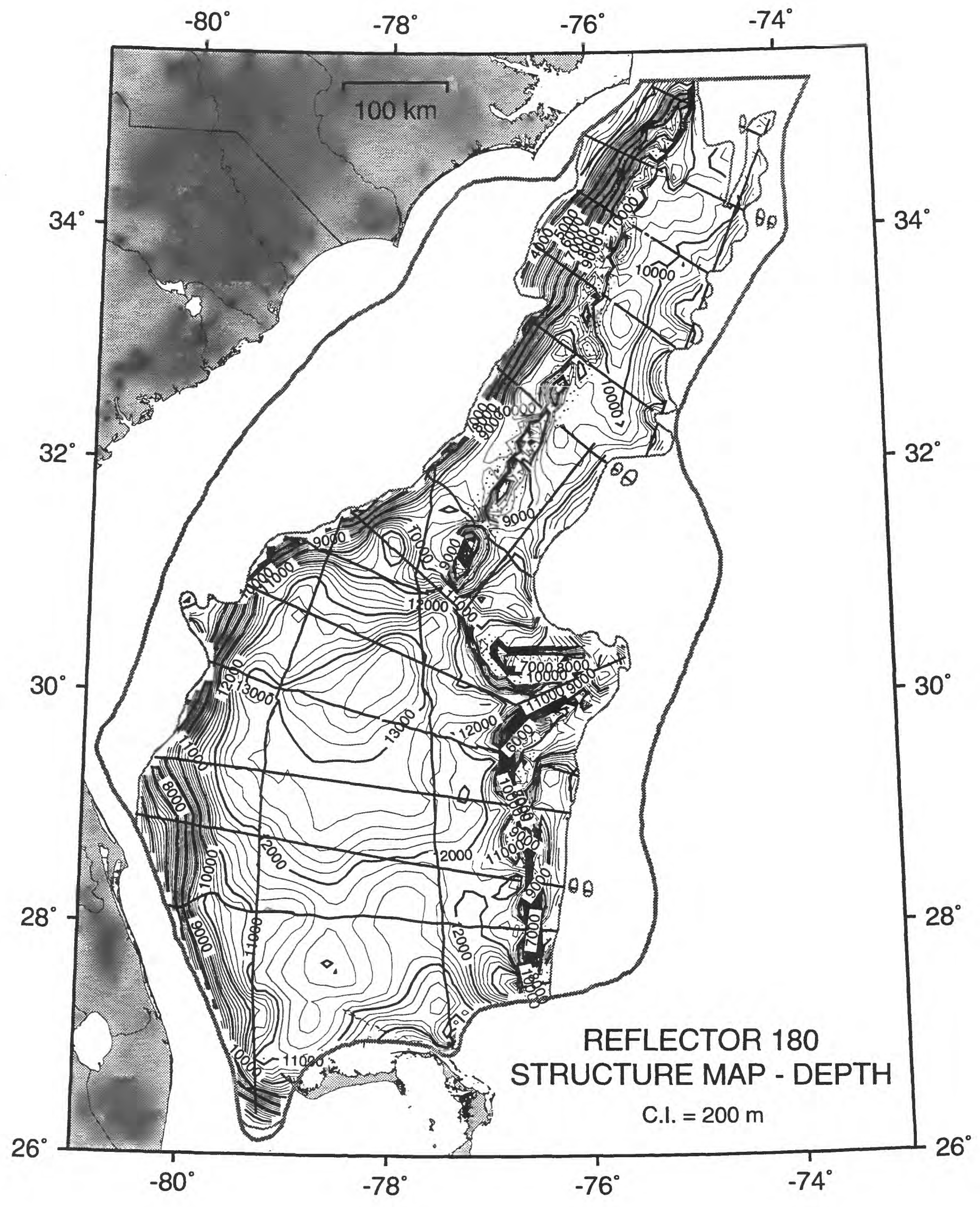




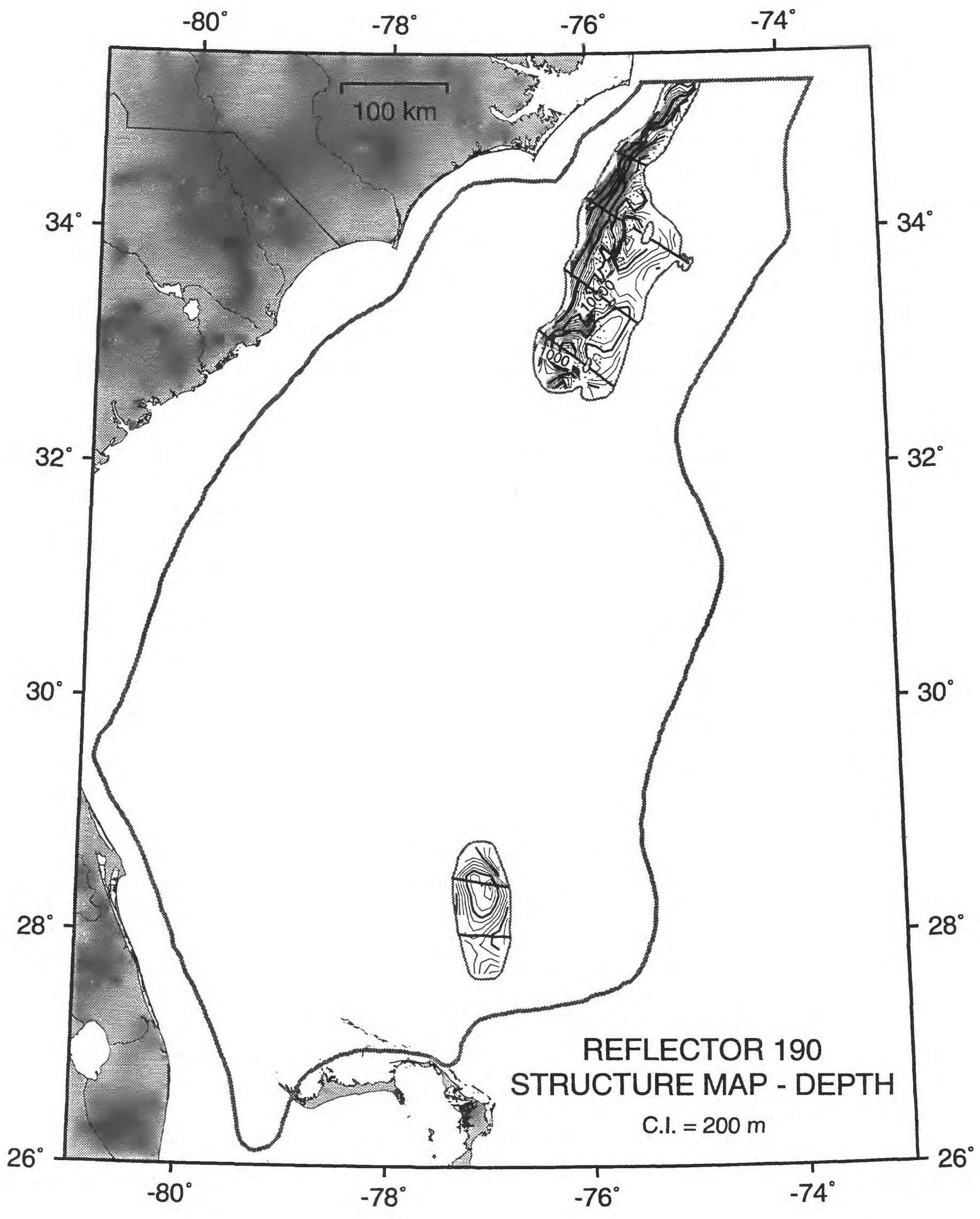




\section{APPENDIX 6}

\section{Gridded Data - Lithology Maps}

Distribution of general sediment type within each acoustic unit is shown in this appendix. Blank areas indicate regions where the unit is absent. Sharp boundaries are drawn between each of the sediment types, but in actuality, these boundaries are probably gradational. Table 6 gives a description of the sediment types differentiated during mapping. 


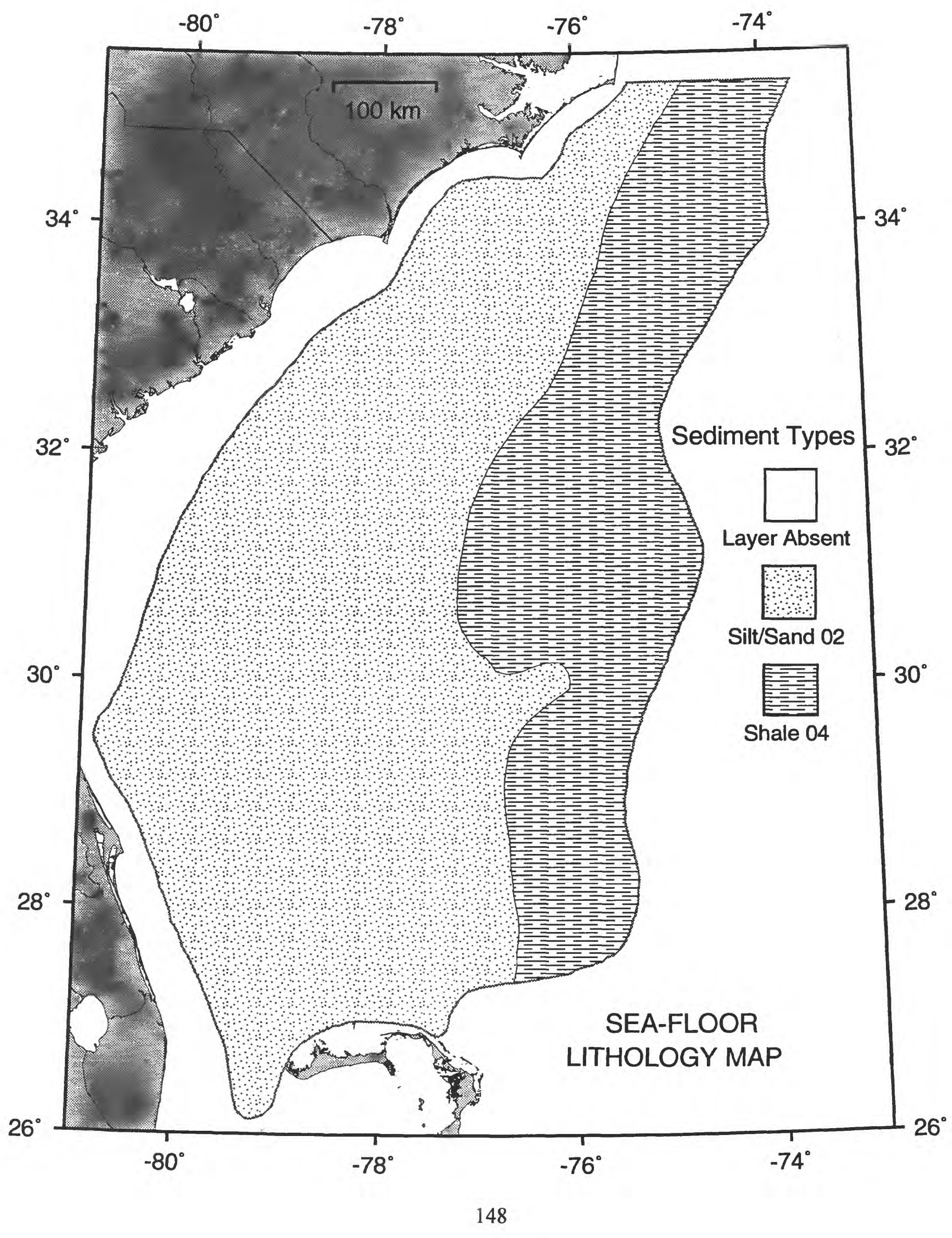




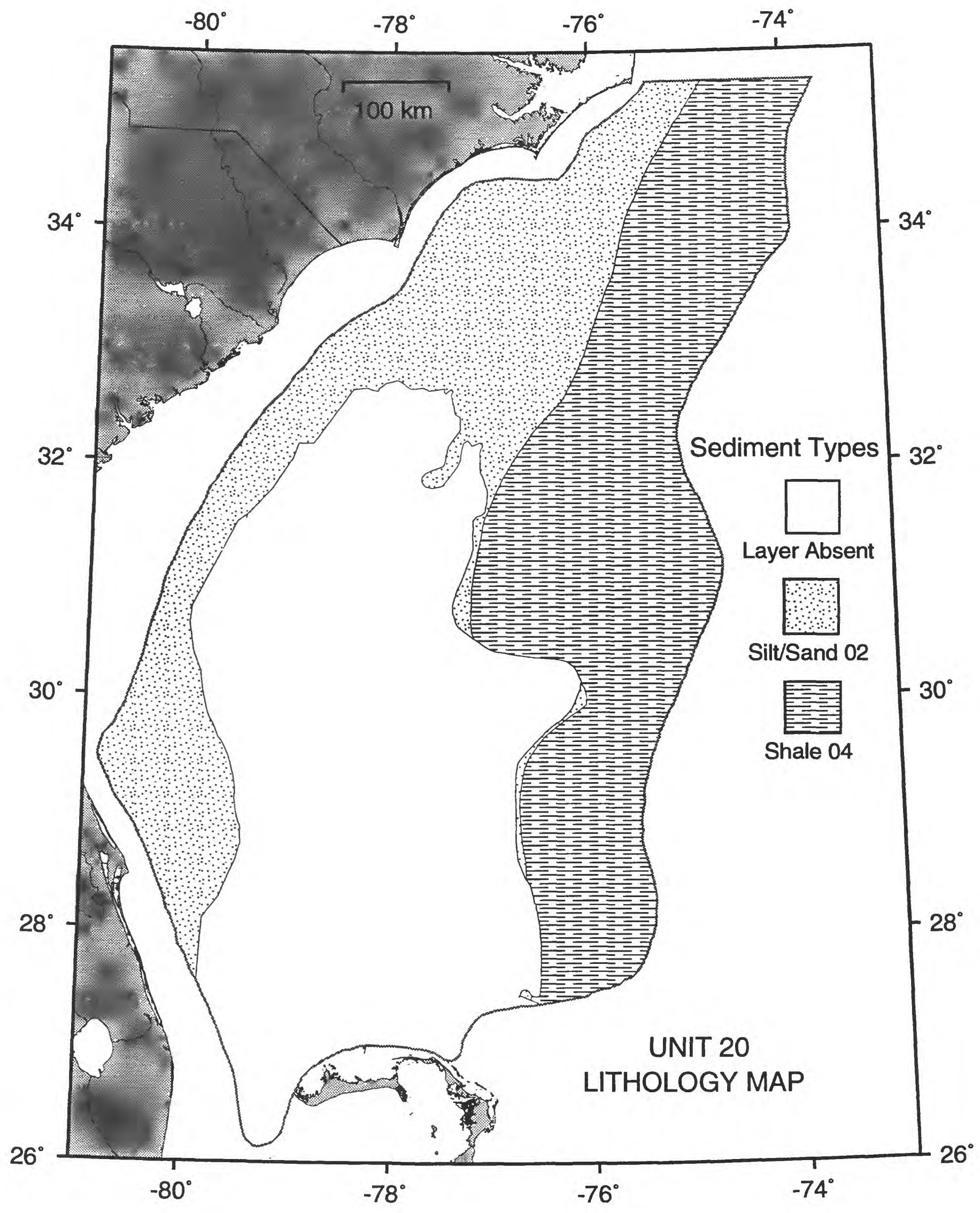




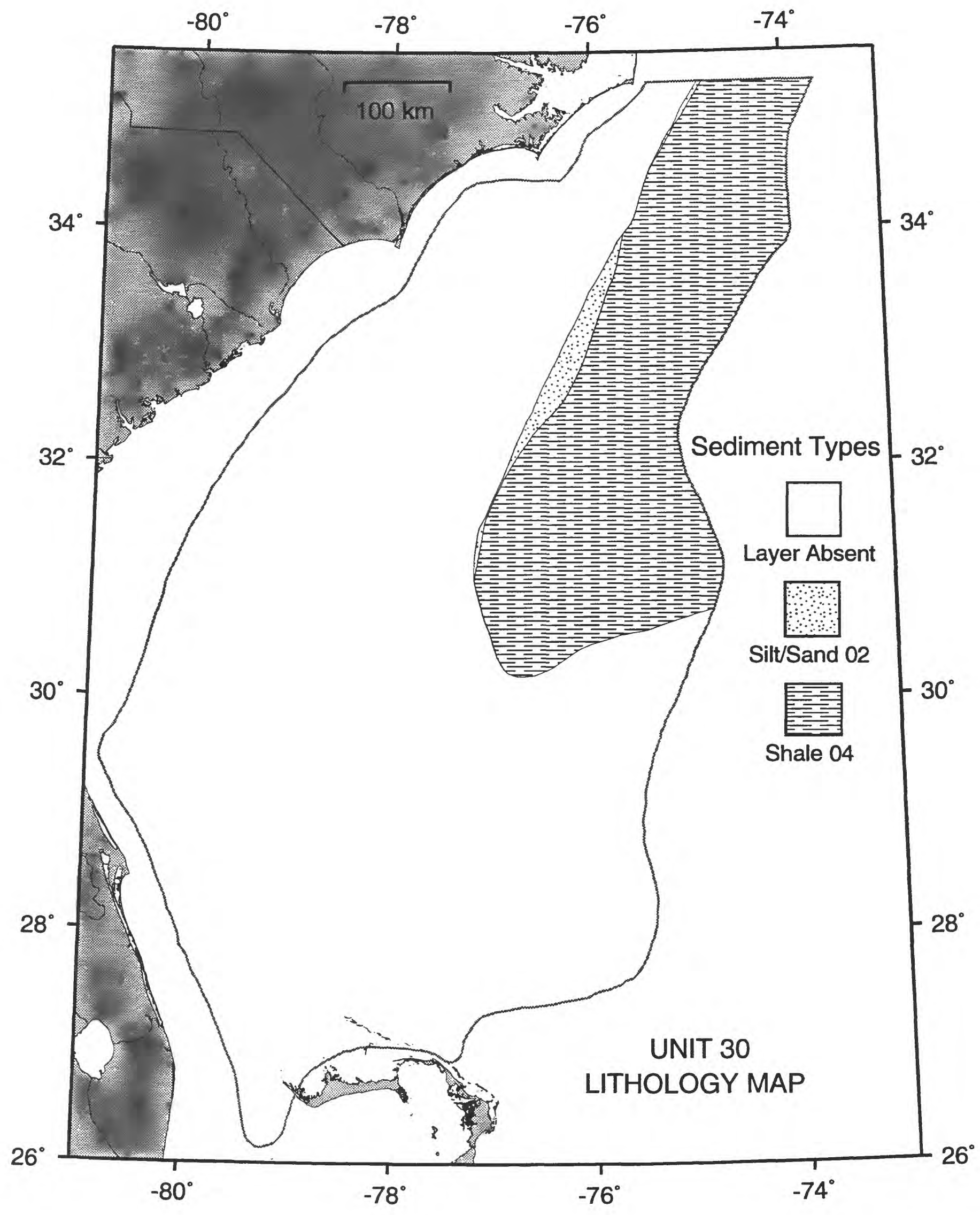




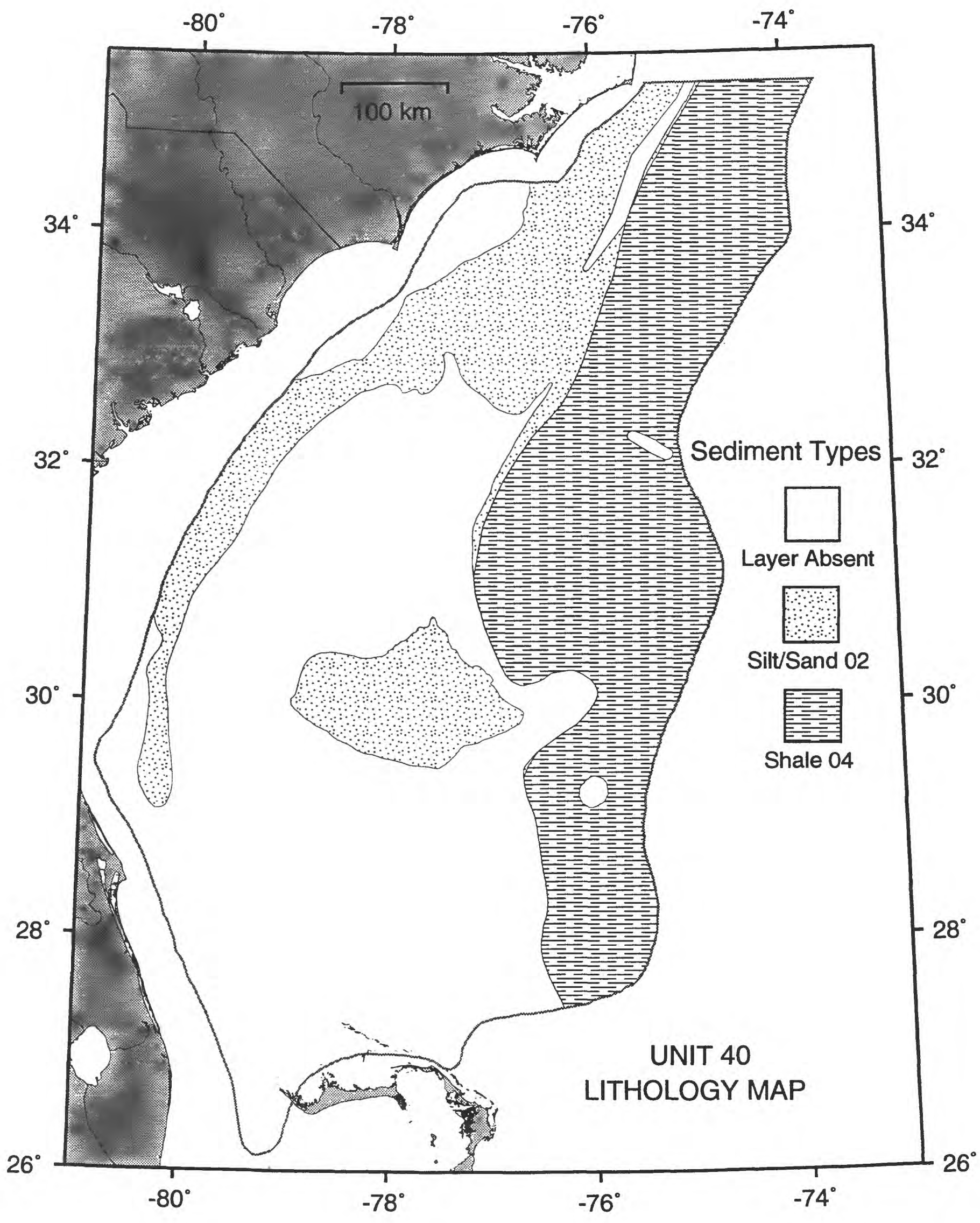




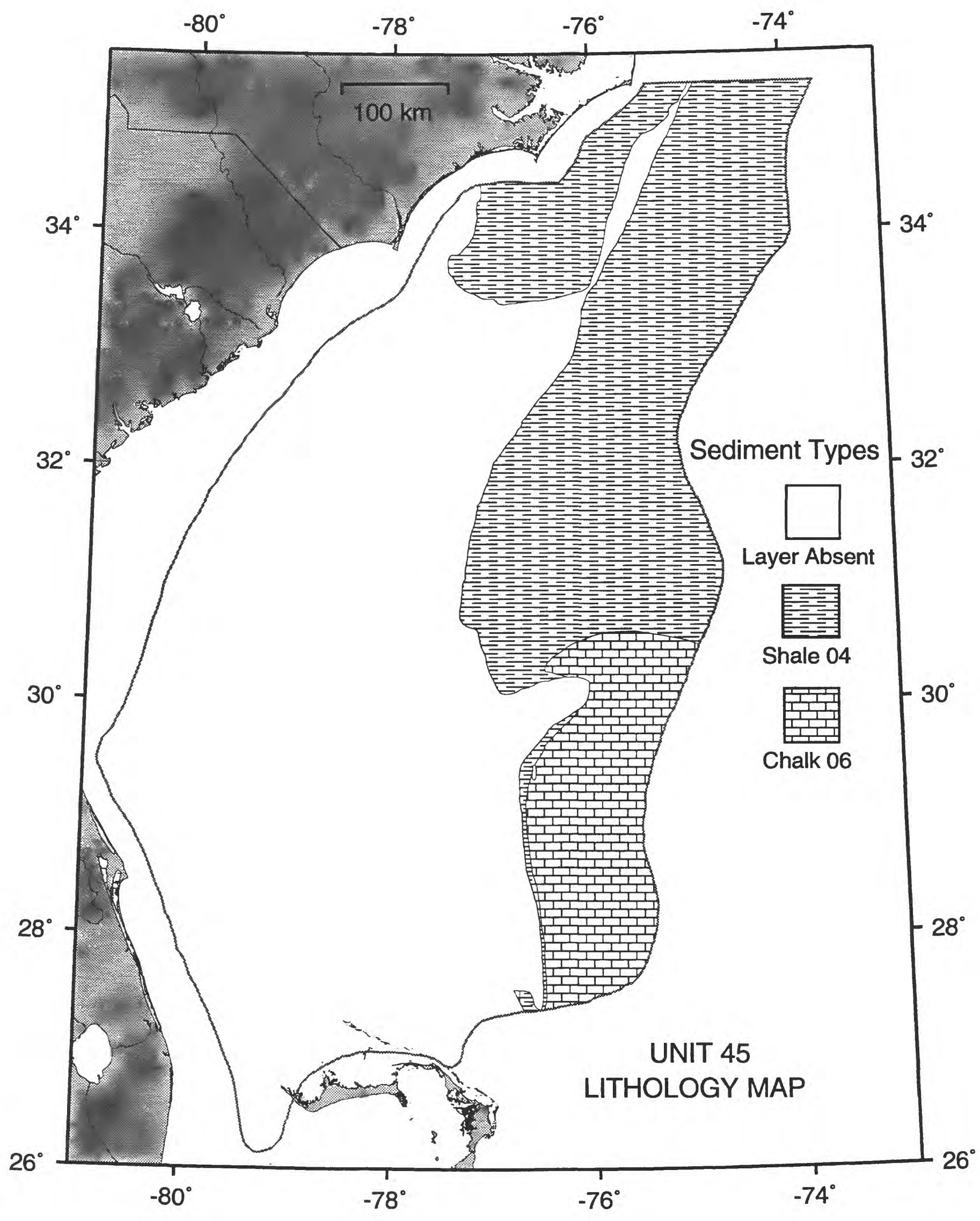




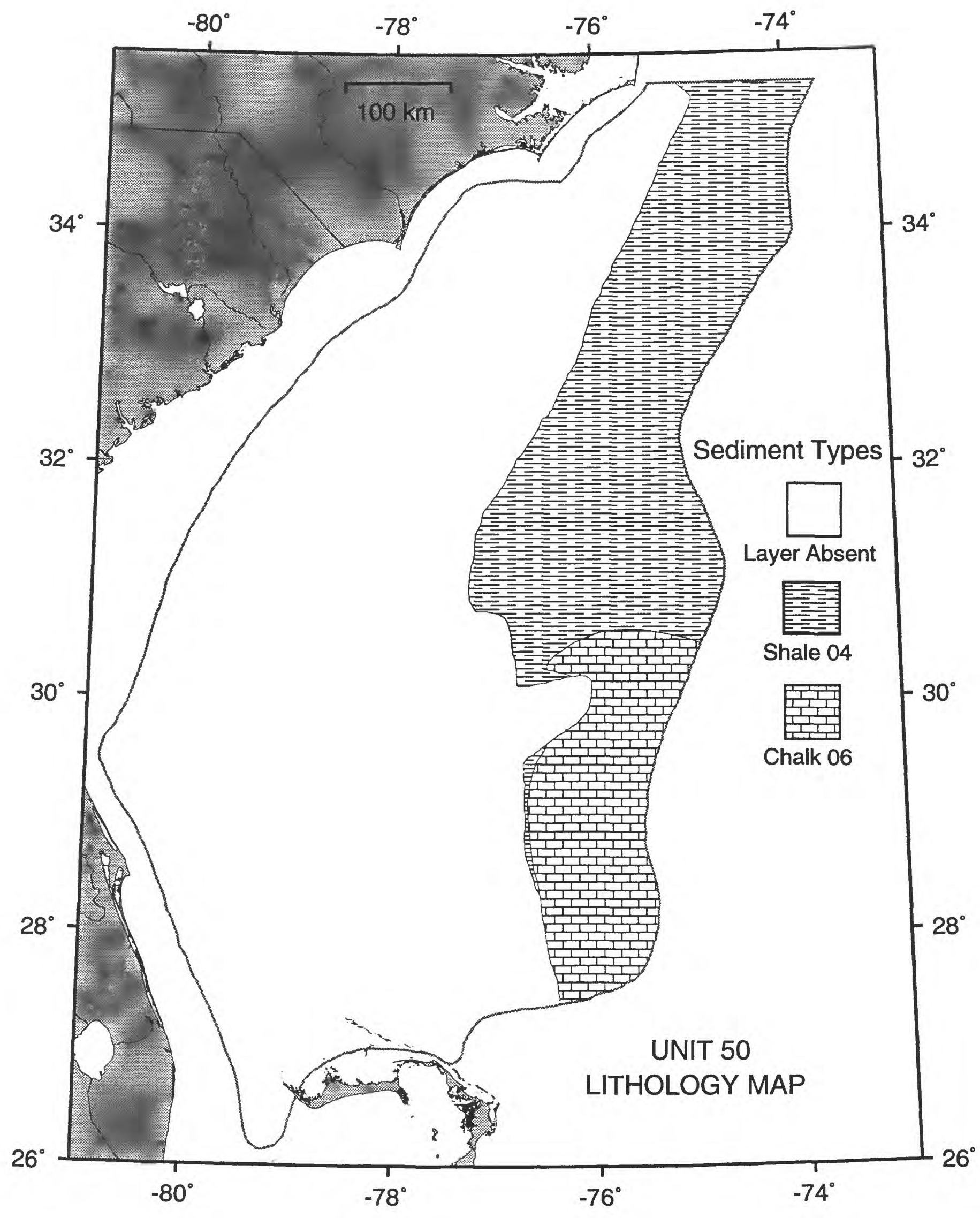




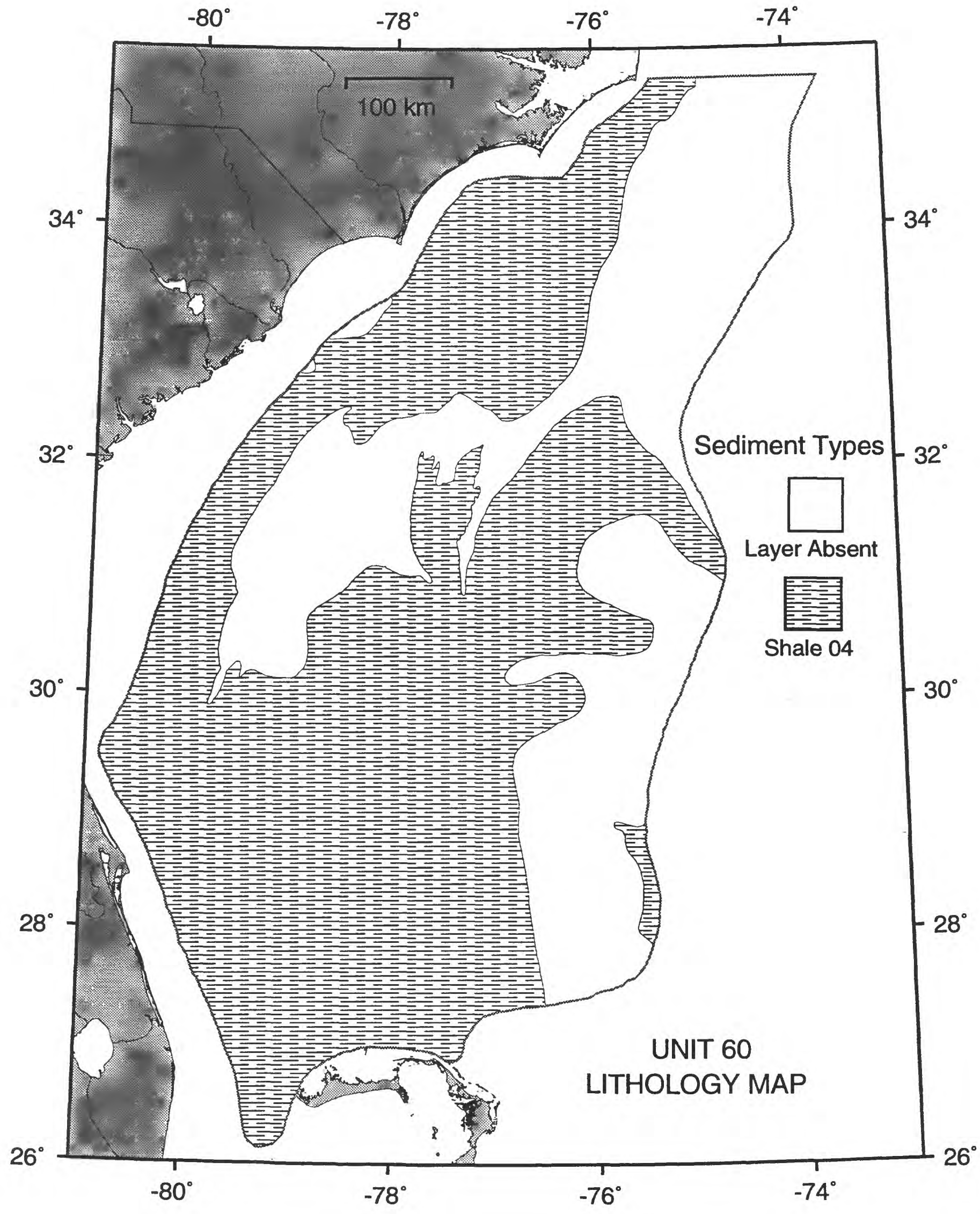




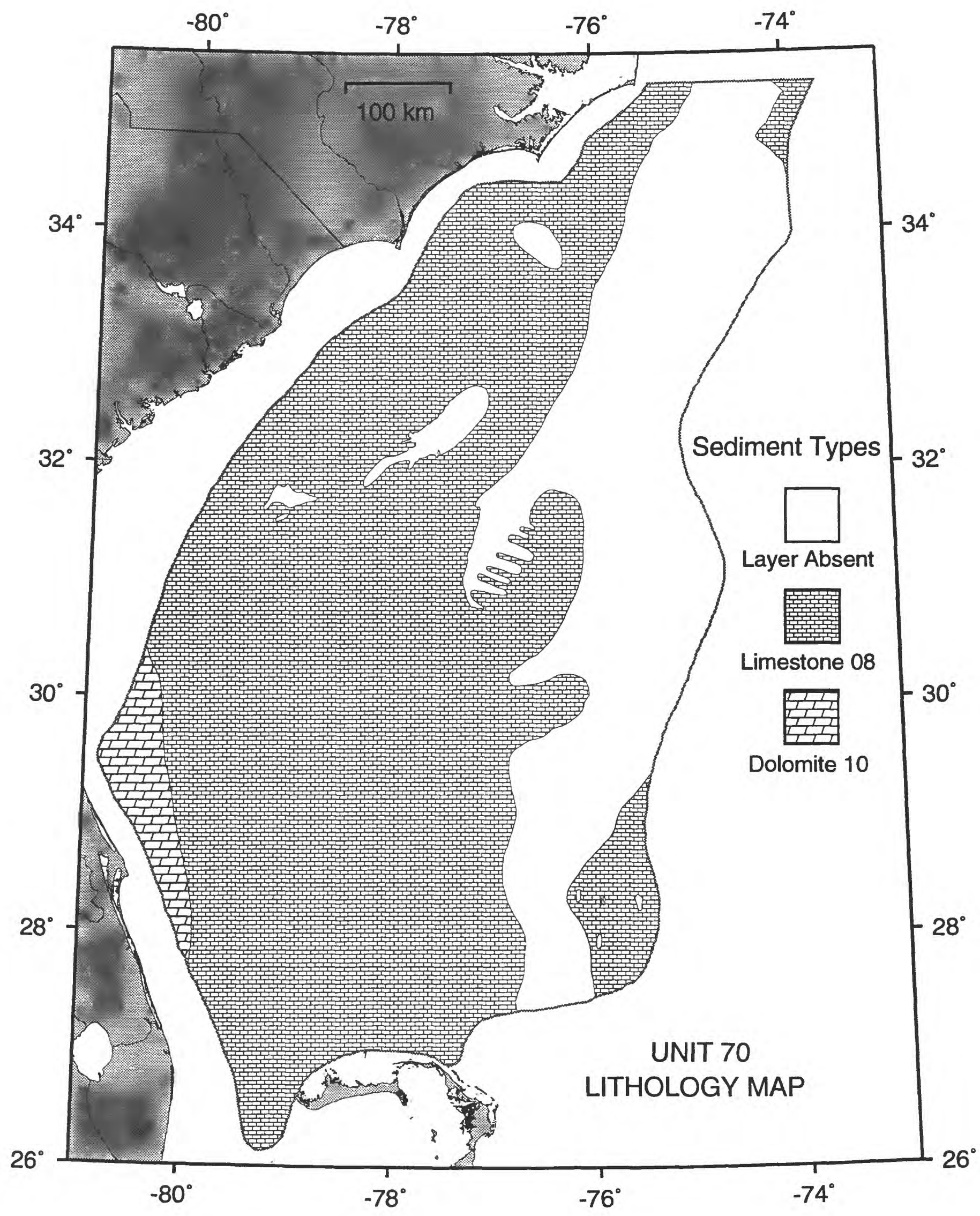




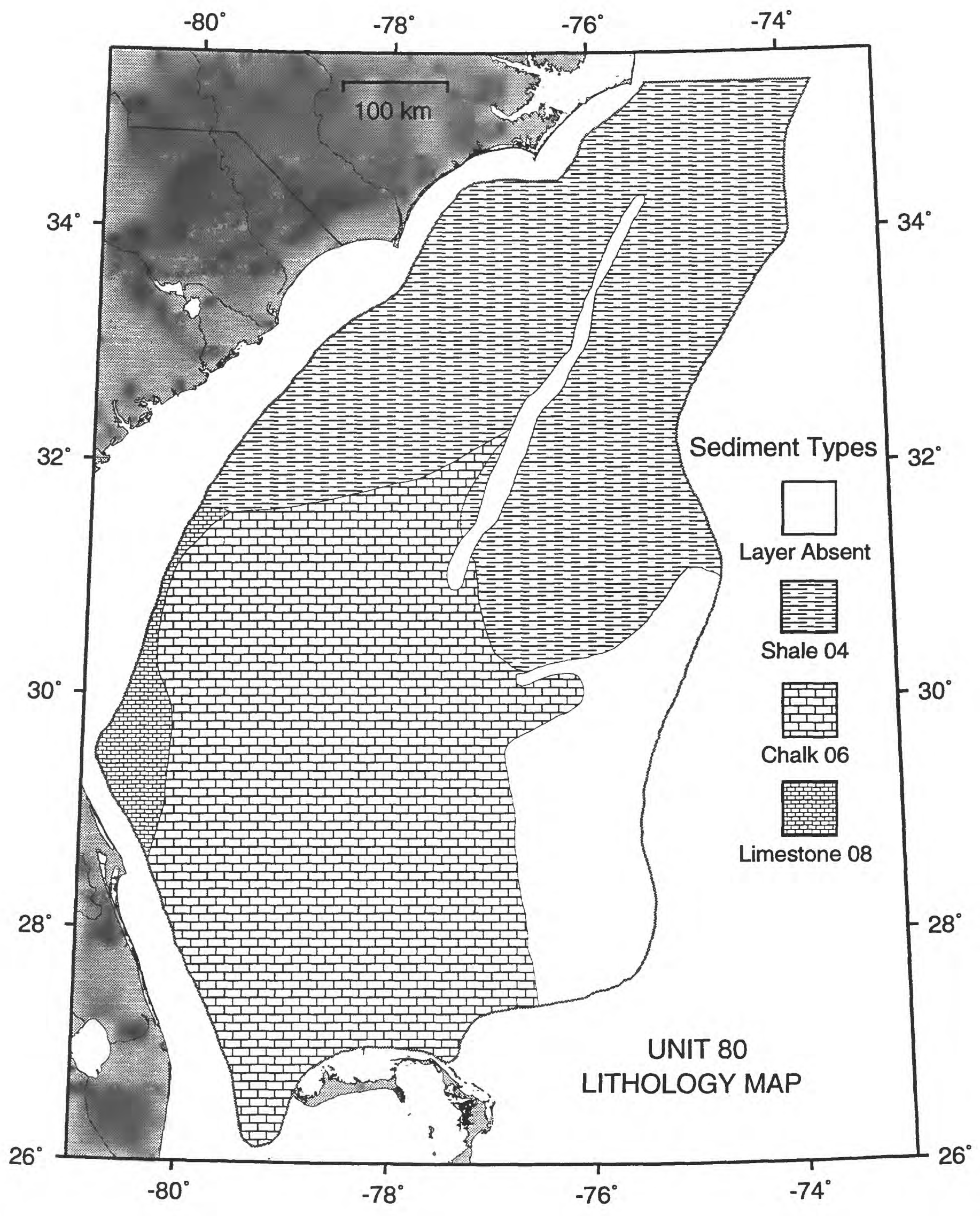




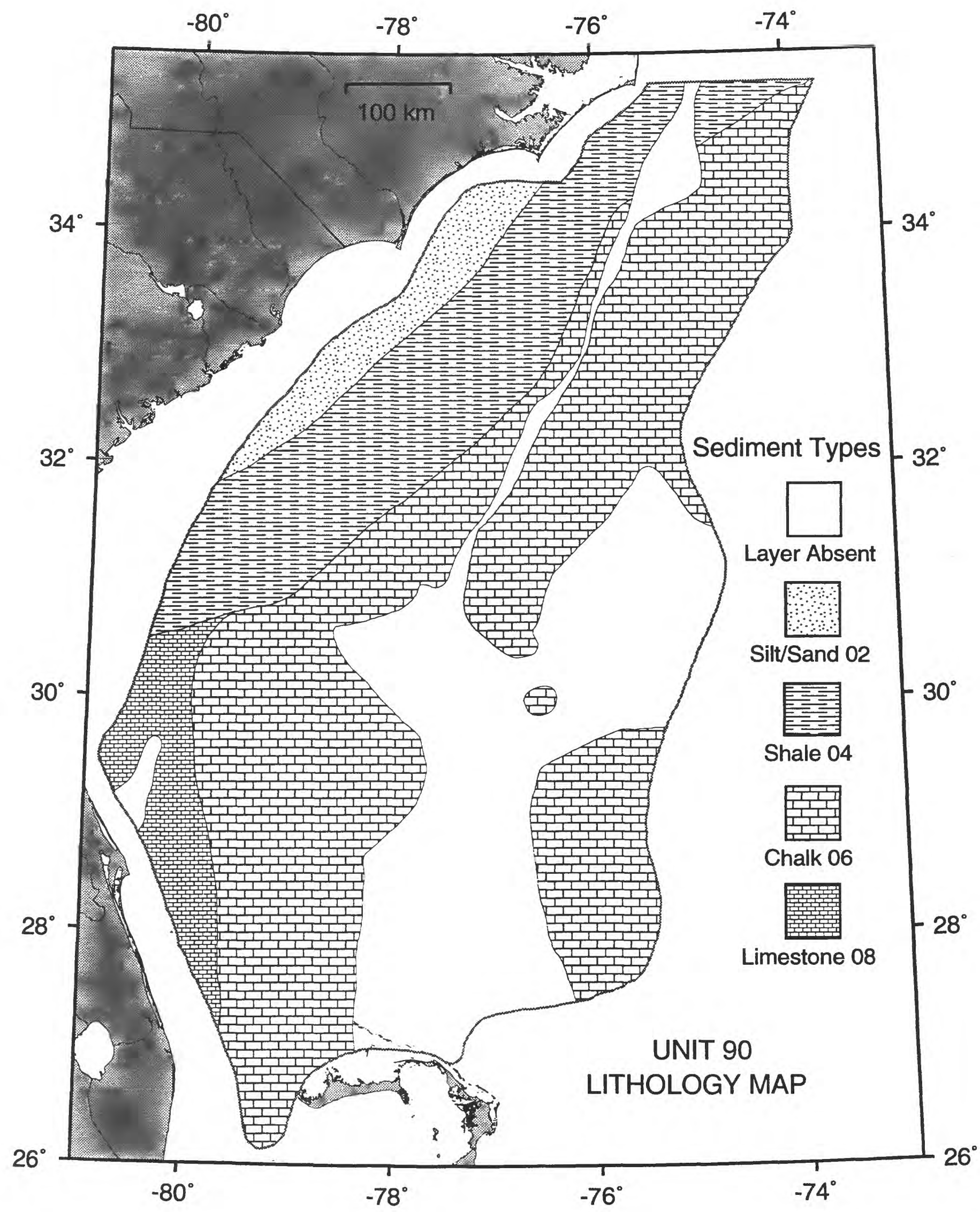




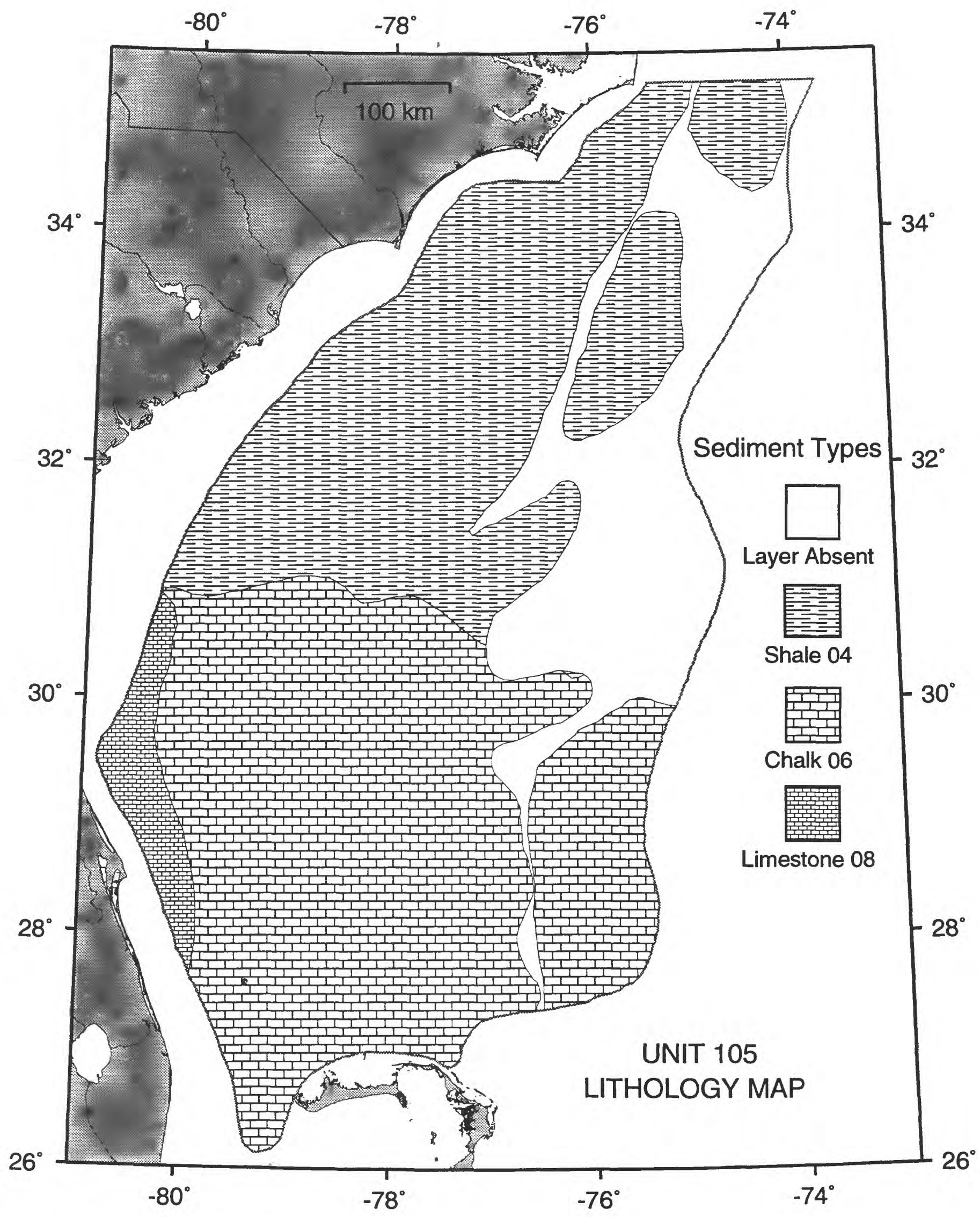




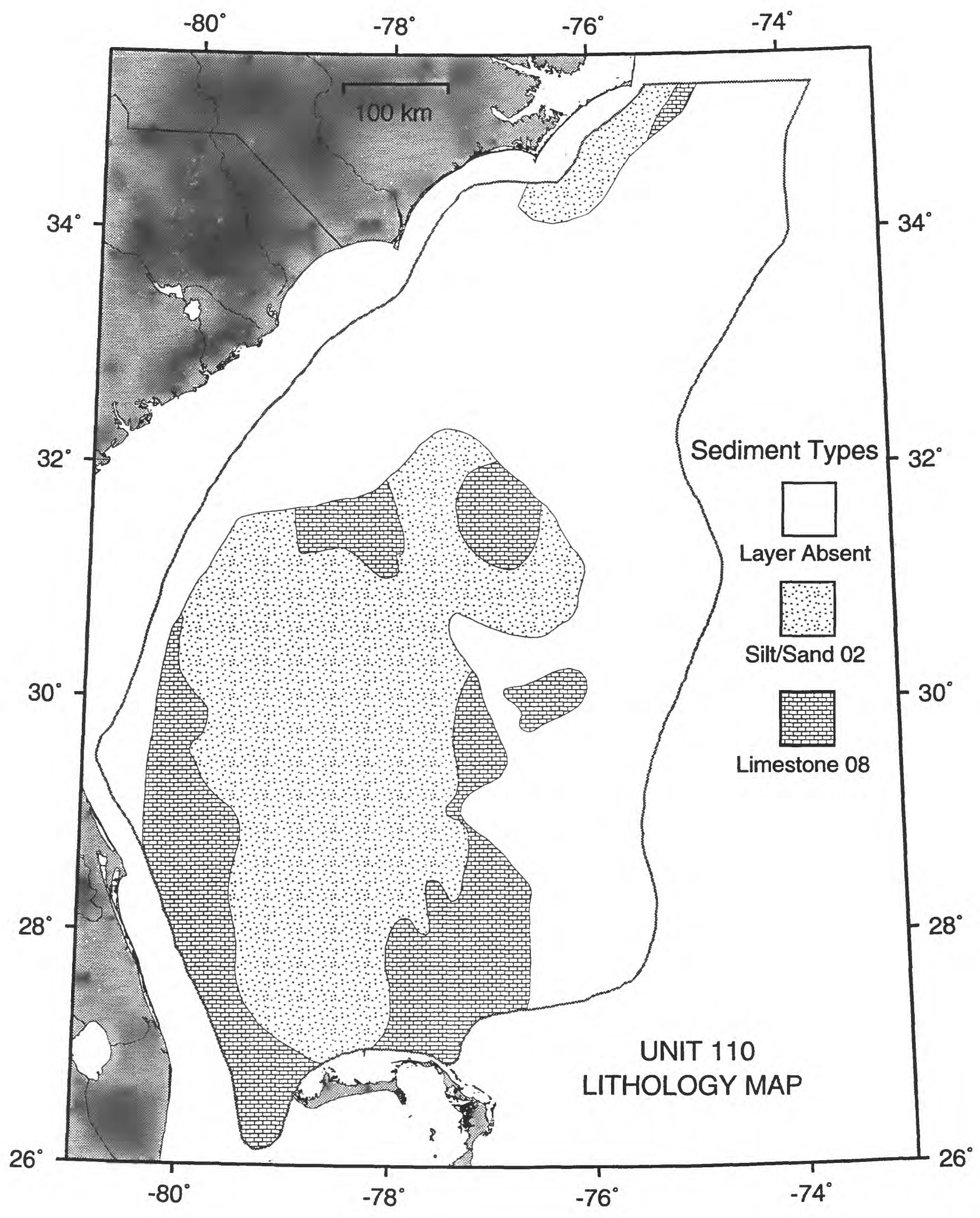




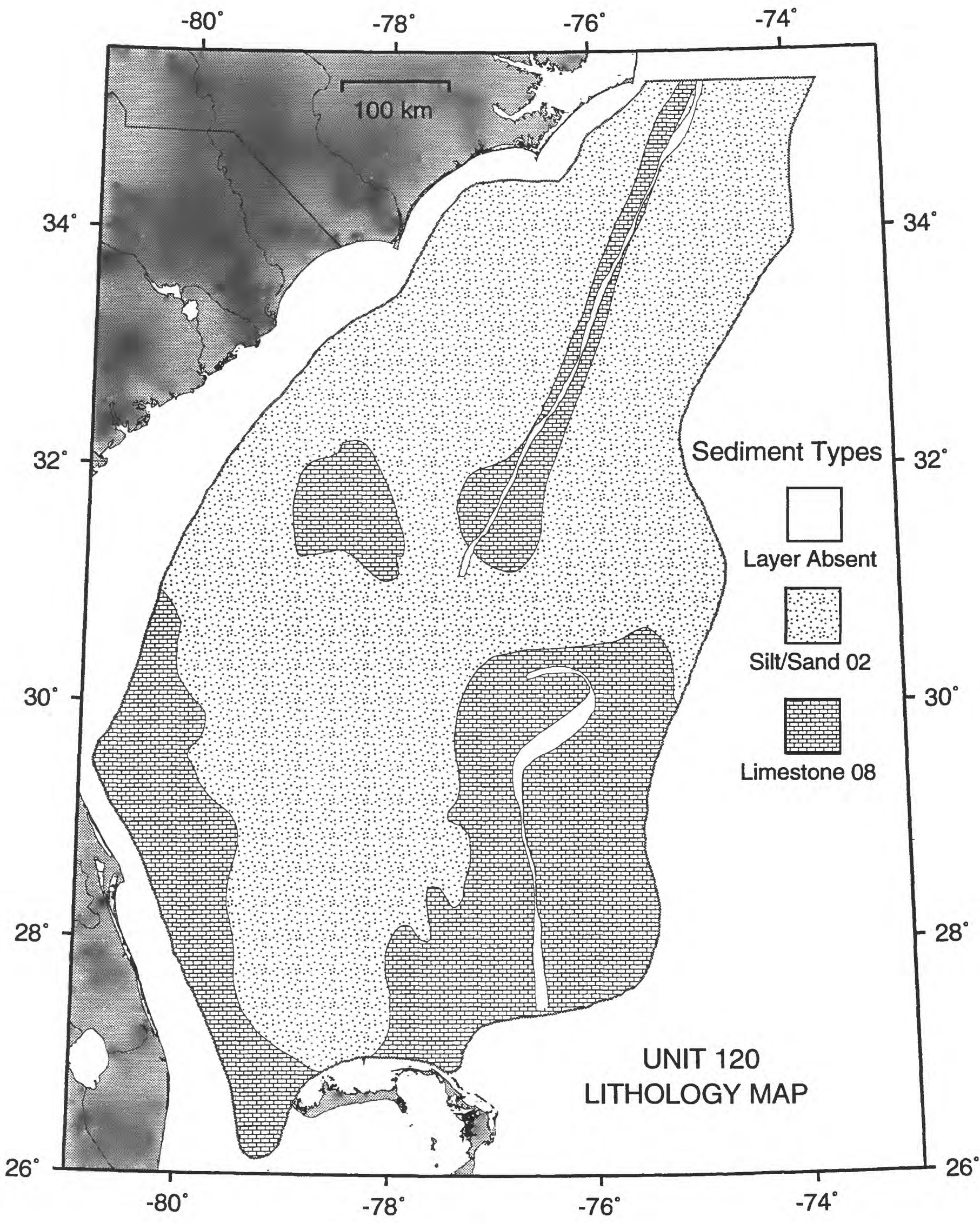




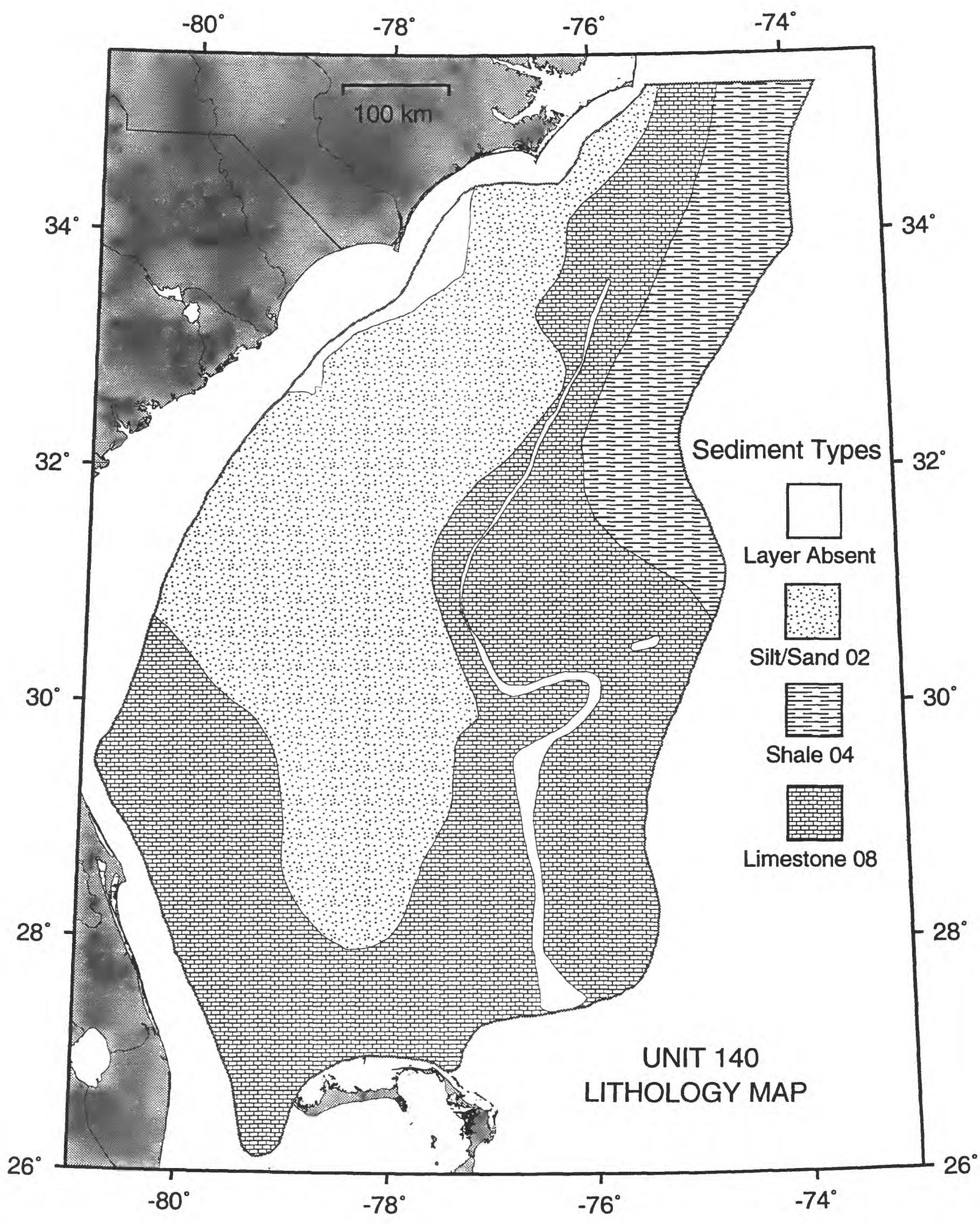




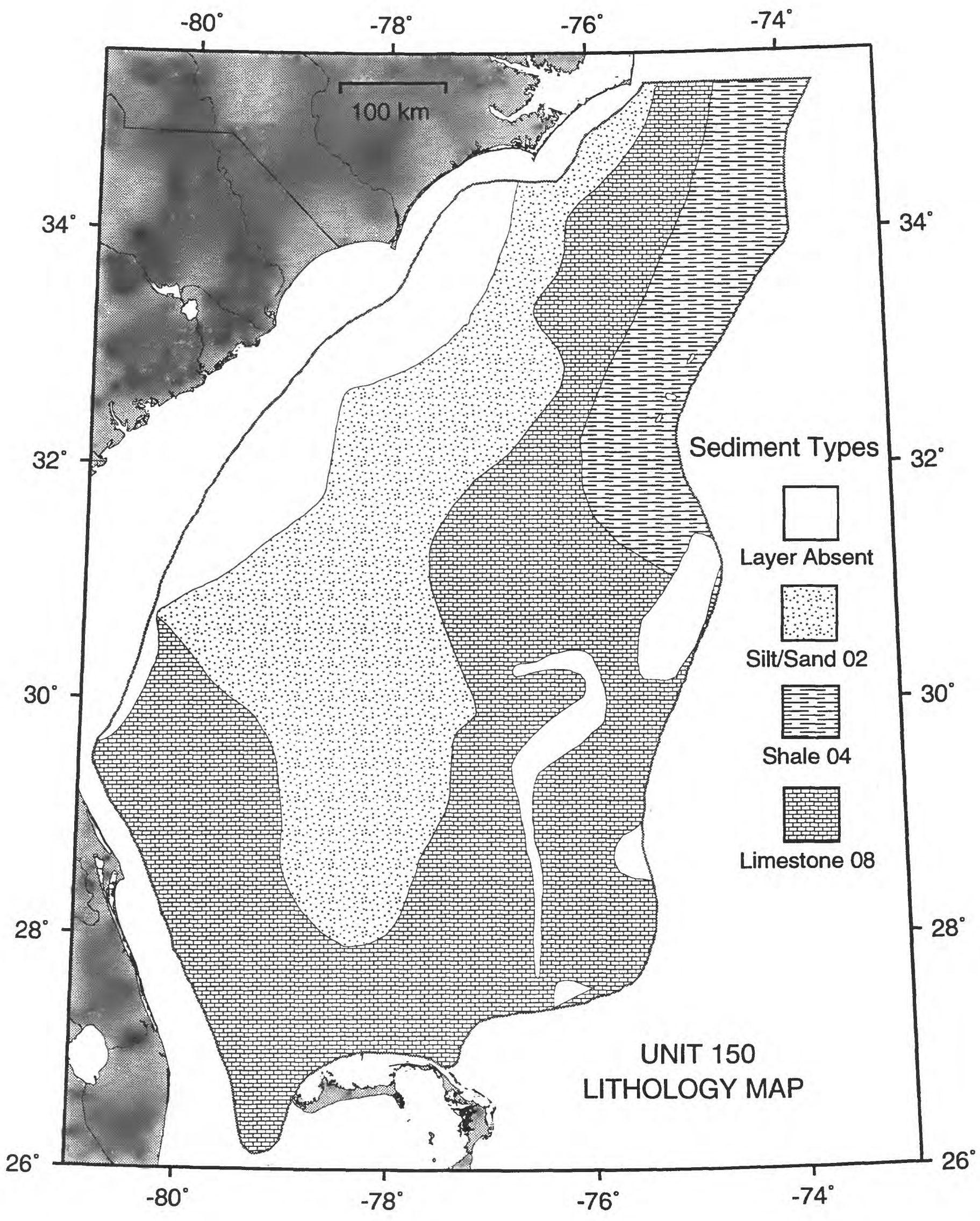




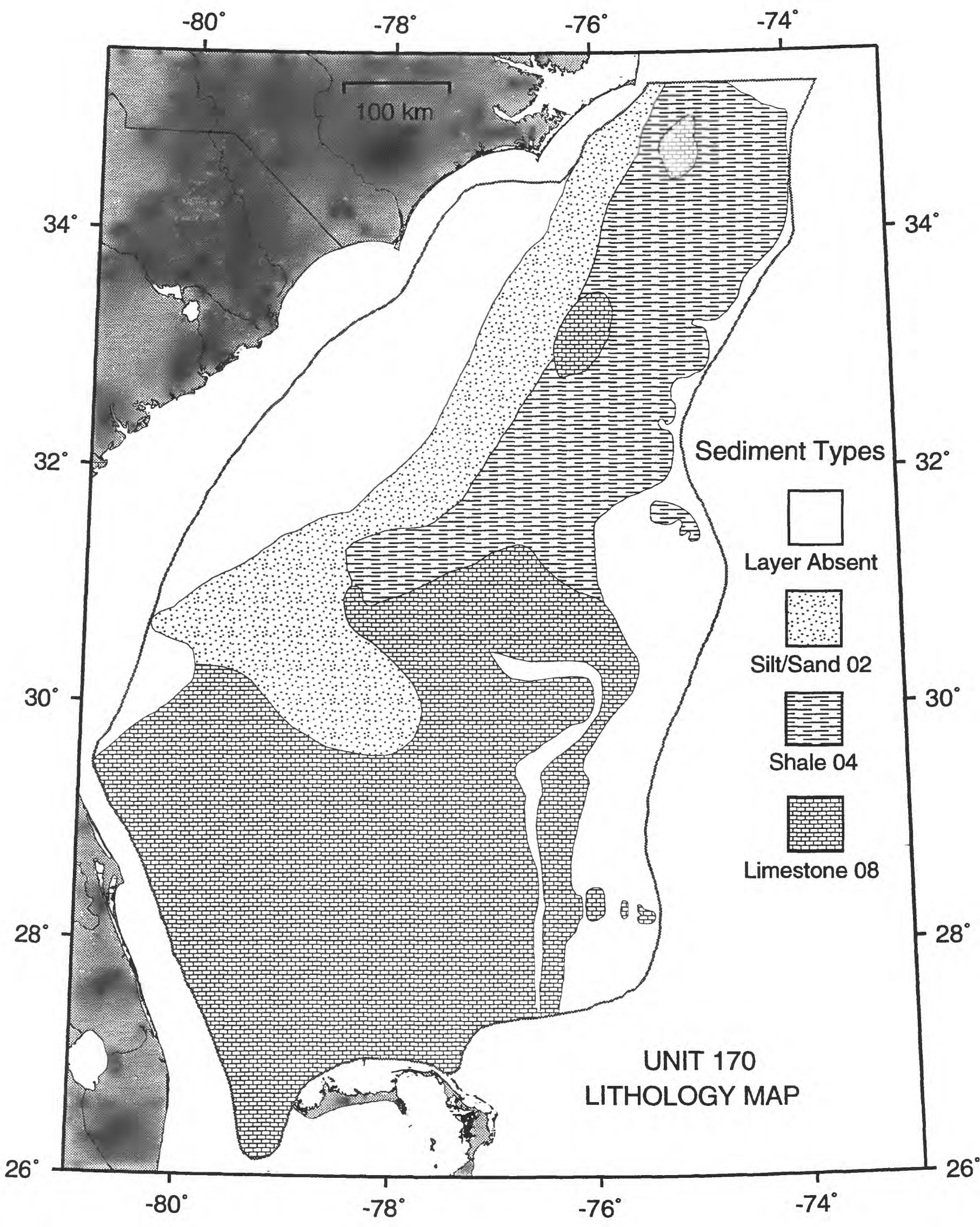




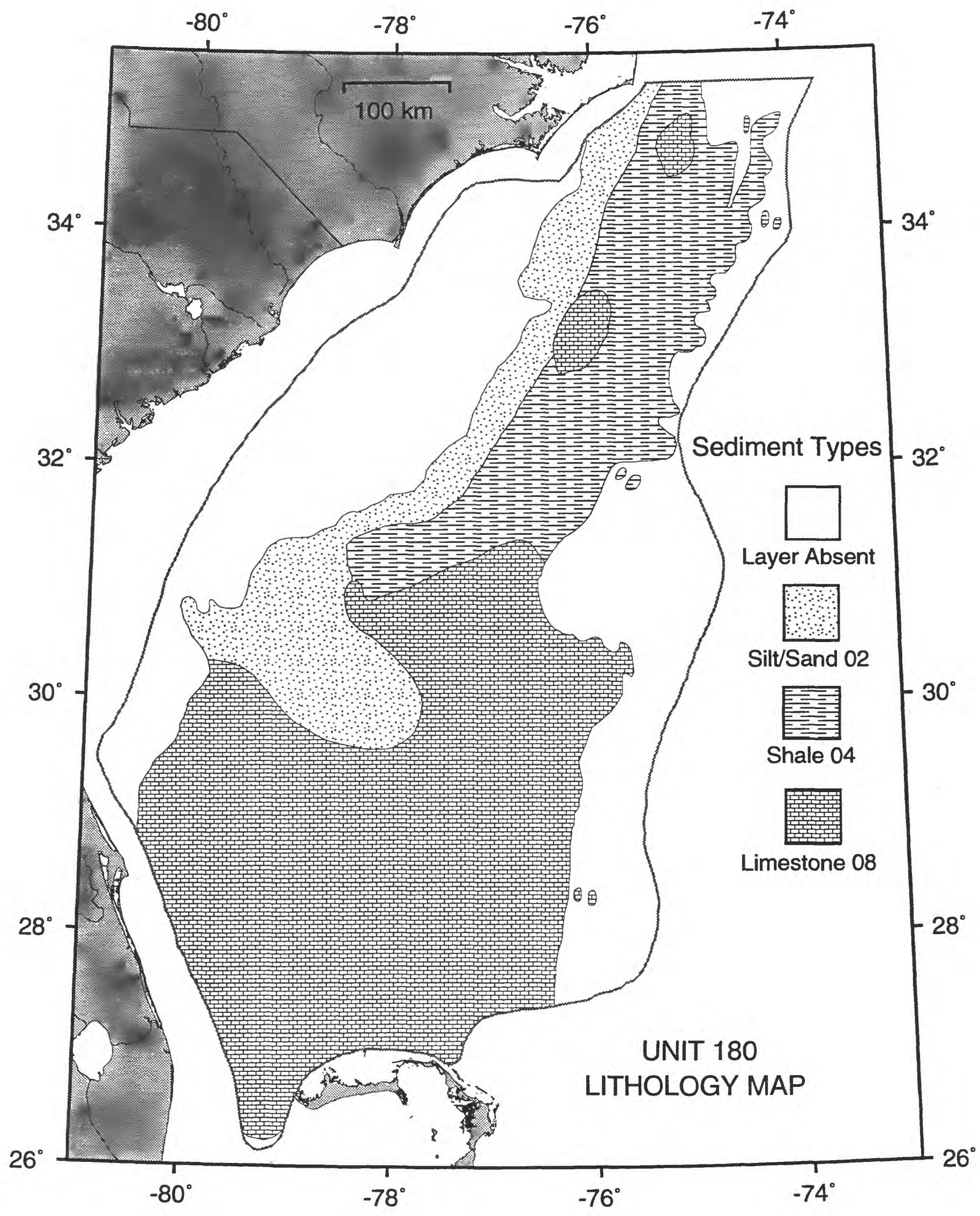




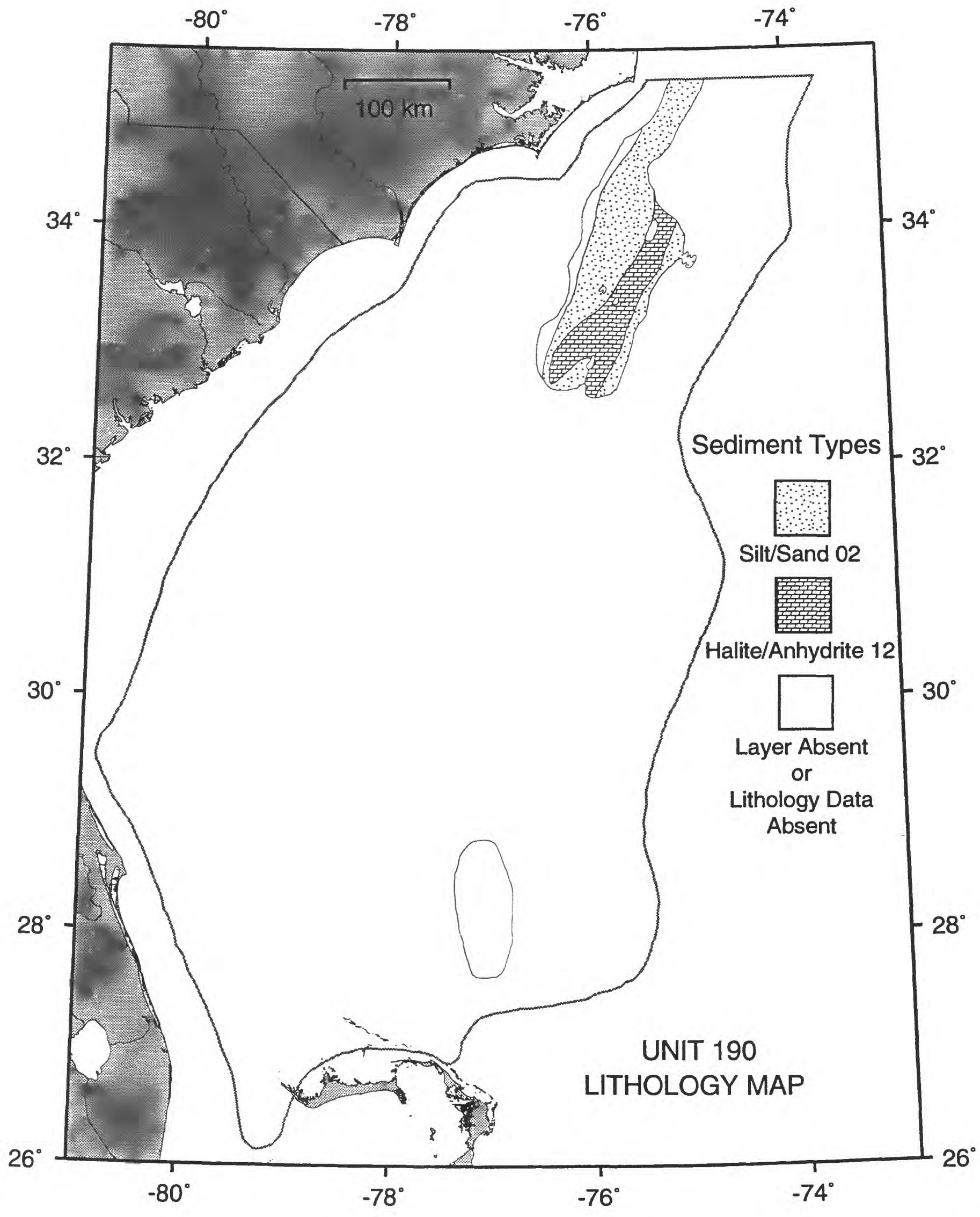

